\title{
Nondestructive evaluation of corrosion in reinforced concrete structures with or without FRP wraps
}

Jonas Kavi

Follow this and additional works at: https://researchrepository.wvu.edu/etd

\section{Recommended Citation}

Kavi, Jonas, "Nondestructive evaluation of corrosion in reinforced concrete structures with or without FRP wraps" (2015). Graduate Theses, Dissertations, and Problem Reports. 5945.

https://researchrepository.wvu.edu/etd/5945

This Thesis is protected by copyright and/or related rights. It has been brought to you by the The Research Repository @ WVU with permission from the rights-holder(s). You are free to use this Thesis in any way that is permitted by the copyright and related rights legislation that applies to your use. For other uses you must obtain permission from the rights-holder(s) directly, unless additional rights are indicated by a Creative Commons license in the record and/ or on the work itself. This Thesis has been accepted for inclusion in WVU Graduate Theses, Dissertations, and Problem Reports collection by an authorized administrator of The Research Repository @ WVU. For more information, please contact researchrepository@mail.wvu.edu. 


\title{
NONDESTRUCTIVE EVALUATION OF CORROSION IN REINFORCED CONCRETE STRUCTURES WITH OR WITHOUT FRP WRAPS
}

\section{Jonas Kavi}

\author{
Thesis submitted to the \\ Benjamin M. Statler College of Engineering and Mineral Resources \\ at West Virginia University \\ in partial fulfillment of the requirements \\ for the degree of
}

\author{
Master of Science \\ in \\ Civil Engineering
}

\author{
Udaya B. Halabe, Ph.D., P.E., Chair \\ Hota V. S. GangaRao, Ph.D., P.E. \\ Hema J. Siriwardane, Ph.D., P.E.
}

\begin{abstract}
Department of Civil and Environmental Engineering
Morgantown, West Virginia
\end{abstract}

2015

Keywords: Corrosion; Carbonation; Chloride Ions; Half-Cell Potential; Resistance;

Electrical Resistivity; Linear Polarization Resistance, LPR; Temperature; Humidity; Fiber Reinforced Polymer, FRP; CFRP; GFRP; Composites; Reinforced Concrete; NDE

Copyright 2015 Jonas Kavi 


\title{
Abstract \\ Nondestructive Evaluation OF CORROSion IN REINFORCED CONCRETE STRUCTURES WITH OR WITHOUT FRP WRAPS
}

\begin{abstract}
Jonas Kavi
Reinforced concrete is one of the most widely used construction materials for infrastructure applications across the world due to its reasonable durability and competitive cost. One of the major concerns with reinforced concrete is the deterioration caused by premature corrosion of embedded steel reinforcement under the influence of moisture, chlorides, and oxygen in the field environment. Fiber Reinforced Polymer (FRP), a material with many engineering properties better than concrete and steel, is increasingly being used in the rehabilitation of aging infrastructure and the construction of new ones.

The need for maintenance and repair of bridges, buildings and other infrastructure for their safety require effective monitoring and evaluation to determine the location and severity/rate of deterioration. Several techniques exist for monitoring corrosion in reinforced concrete. These techniques are primarily based on monitoring of concrete resistivity, moisture content, electric potential, or change in resistance of an embedded element. Most of these existing techniques require the structural member to be accessible for scanning operations. Also, many of these techniques are not applicable for monitoring corrosion in structures with FRP shells/jackets and/or wraps covering the concrete surface.
\end{abstract}

The objective of this research was to develop a low cost and durable electrical resistivity sensor that can be embedded in any type of reinforced concrete structure, with or without FRP wraps. This was achieved by designing a low cost sensor that can measure electrical resistivity of concrete and can be used to assess the moisture content. This study utilized the electrical resistivity sensor in addition to commercially available temperature/humidity sensor for determining the potential for corrosion in the structure. Calibration curves were developed for data interpretation using these sensors. The sensors were then installed inside field columns during a bridge rehabilitation project in East Lynn, West Virginia, to collect data on the potential for further corrosion of embedded steel within the concrete columns of the bridge after the rehabilitation work. Data from these sensors indicate that there is no corrosion activity in the steel pile encased in concrete during the first year following the structural rehabilitation. 


\section{ACKNOWLEDGEMENTS}

I would like to express my sincere gratitude to my academic and research advisor, Dr. Udaya B. Halabe, for his support and guidance during my Master of Science in Civil Engineering (MSCE) degree program. I am thankful for the opportunity to work under Dr. Halabe, an experienced and knowledgeable faculty member in the field of nondestructive testing and evaluation.

I would also like to thank Dr. Hota V. S. GangaRao and Dr. Hema J. Siriwardane, for serving as members on my Advisor and Examining Committee (AEC). I am grateful to Dr. Siriwardane for allowing me to use the heating oven available in the Geotechnical laboratory for determining concrete moisture content.

I would like to express my appreciation to CFC Technician, Mr. Jerry Nestor, for helping me in the laboratory. I would also like to thank Mr. Mark Skidmore and Dr. Ray Liang for providing me with valuable field rehabilitation experience.

I gratefully acknowledge the financial support provided by the U.S. Army Corps of Engineers (USACE) under Contract No. IIP-1230351 that enabled me to undertake this research.

Finally, I would like to take this opportunity to thank my friends and family (especially Mr. Richard Atsu Kavi, Mrs. Victoria Kavi and Mrs. Lucy Akosua Boachi) for their endless support and encouragement throughout this study. 


\section{TABLE OF CONTENTS}

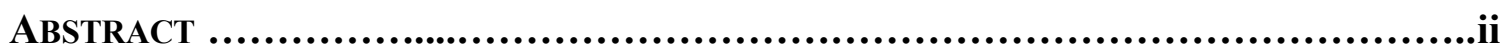

ACKNOWLEDGEMENTS ................................................................................................. iii

TABLE OF CONTENTS ...................................................................................................... iv

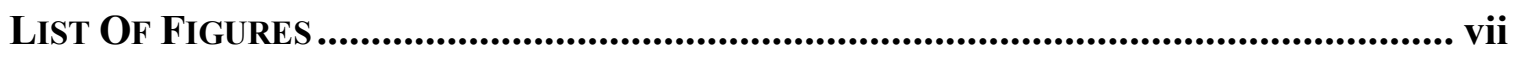

LIST OF TABLES.......................................................................

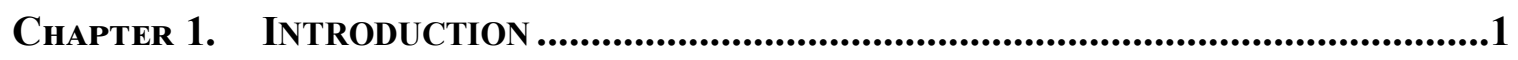

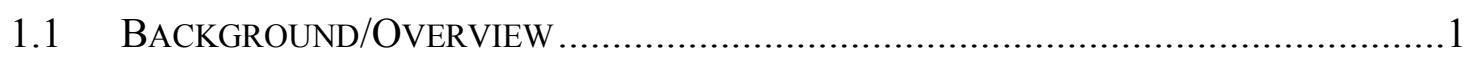

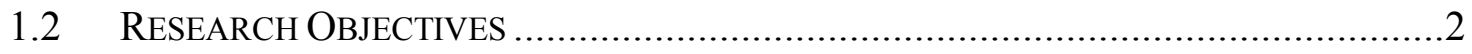

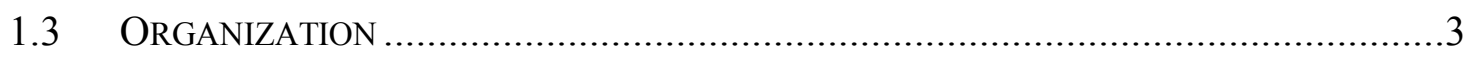

ChaPTER 2. CORROSION OF EXPOSED AND ENCASEd STEEL.............................................5

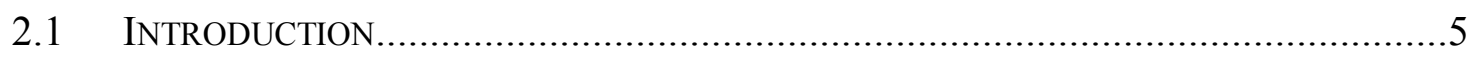

2.2 CORROSION OF EXPOSED STEEL ..................................................................

2.3 CORROSION OF ENCASED STEEL …………...............................................

2.3.1 Carbonation of Reinforced Concrete ....................................................

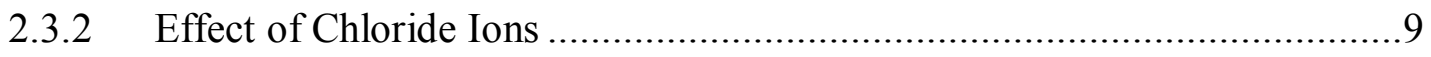

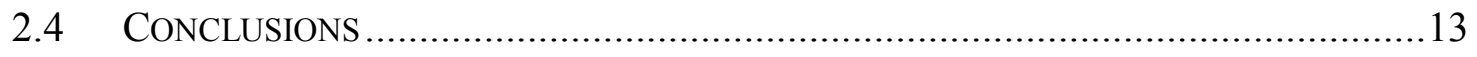

Chapter 3. CORROSION MONITORING TeChNIQUeS .....................................................14

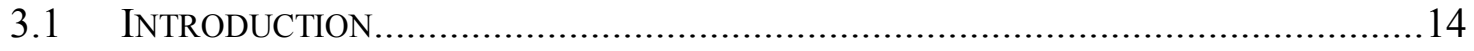

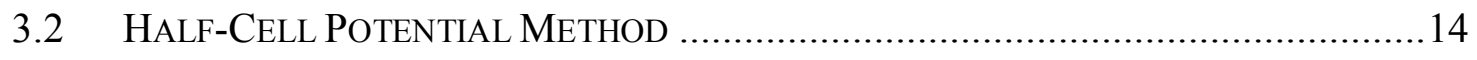

3.2.1 Limitations of Half-Cell Potential Method ..................................................17

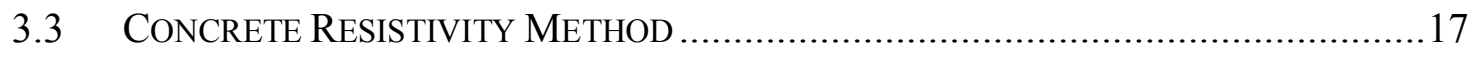

3.3.1 Limitations of Concrete Resistivity Method..............................................20 
3.4 LinEAR PolariZATION RESISTANCE METHOD .............................................20

3.4.1 Limitations of Linear Polarization Method ….....................................25

3.5 EMBEDDED CORROSION SENSORS .............................................................25

3.5.1 VTI ECI Corrosion Monitoring Device..............................................25

3.5.2 Low-Cost, Passive Sensor for Corrosion Detection ..............................27

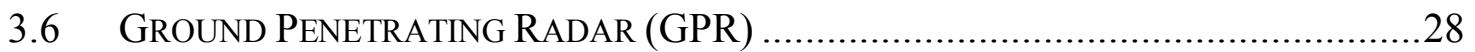

3.6.1 Limitations of Ground Penetrating Radar............................................. 30

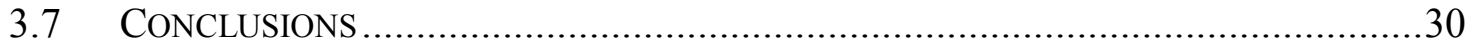

Chapter 4. EXPerimental Design Methodology.............................................33

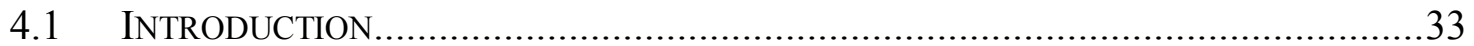

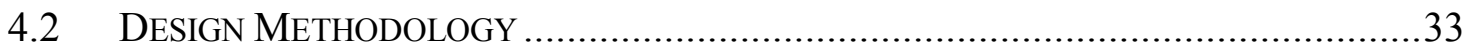

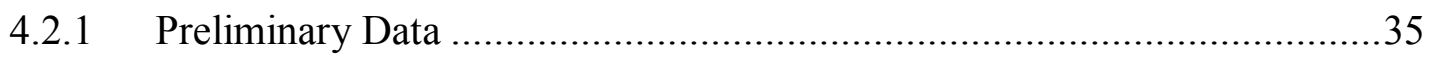

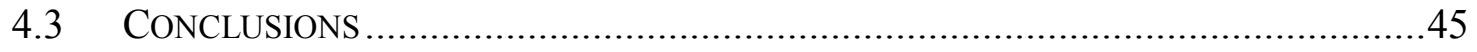

Chapter 5. CORrosion Monitoring in Reinforced ConCRete Members .......46

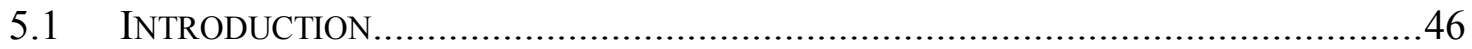

5.2 FinAL RESISTANCE SENSOR GEOMETRY..................................................46

5.3 TEMPERATURE /HUMIDITY SENSOR.........................................................4 49

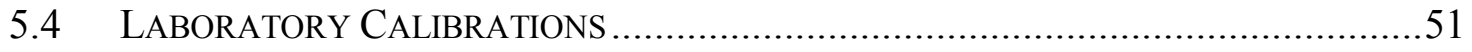

5.4.1 Moisture Content Computation ......................................................52

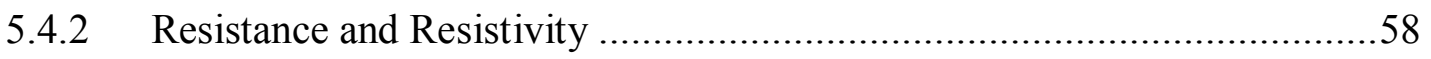

5.4.3 Temperature and Humidity ............................................................66

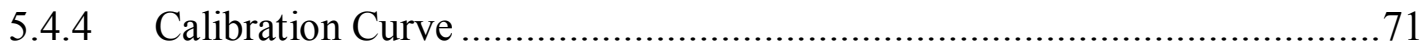

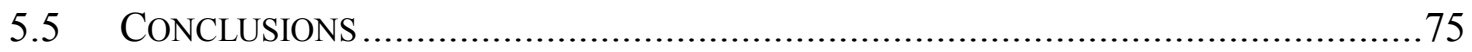

Chapter 6. Field APPlication/Monitoring.................................................76 


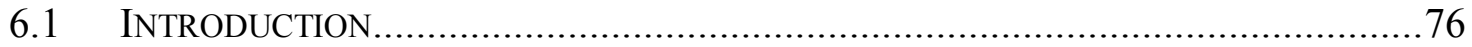

6.2 OVERVIEW OF EAST LYNN LAKE BRIDGE.............................................. 76

6.3 BRIDGE REHABILITAtion AND InStaLlation OF SENSORS .............................79

6.4 FiELD DATA COLLECTION AND INTERPRETATION ........................................85

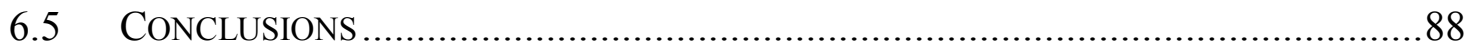

ChAPTER 7. CONCLUSIONS AND RECOMMENDATIONS..............................................899

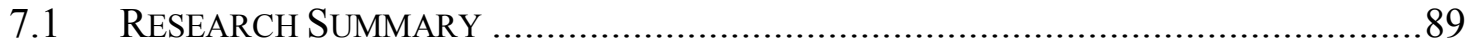

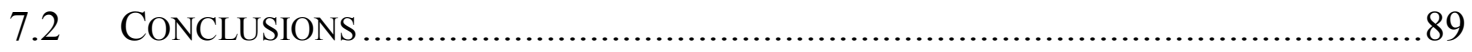

7.3 RECOMMENDATIONS FOR FUTURE STUDIES ............................................. 90

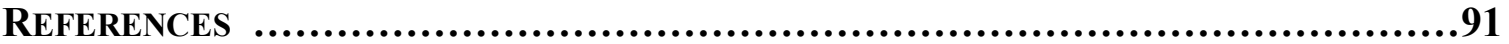

APPENDIX A: PRELIMINARY DESIGN LABORATORY DATA ..........................................97

APPENDIX B: LABORATORY CALIBRATION DATA.................................................105 


\section{LIST OF FIGURES}

Figure 2-1 Four requirements of an electrochemical corrosion cell ...............................7

Figure 2-2 Different definitions for critical chloride content (Angst \& Vennesland 2009)

Figure 2-3 Mechanism of interaction between carbonation and chloride penetration (Yoon 2007)

Figure 2-4 Corrosion of encased steel

Figure 3-1 Half-cell potential apparatus

Figure 3-2 Illustration of half-cell potential readings (Proceq SA 2012)

Figure 3-3 The four point Wenner probe (top left, Carino 2004), and Wenner probe testing on a bridge deck (bottom left and right, from Gucunski et al. 2009)

Figure 3-4 Linear polarization instrument (James Instruments 2002).

Figure 3-5 Details of Sensor A (James Instruments 2002, USDOT 2015)

Figure 3-6 Embedded Corrosion Instrument, ECI, (VTI 2014) .26

Figure 3-7 (a) Corrosion sensor configuration; (b) Change in phase response due to the presence of sacrificial element (Abu Yosef et al. 2012a).

Figure 3-8 A schematic representation of the components of the passive sensor prototype (Abu Yosef et al. 2012b)

Figure 3-9 GPR scanning set up on the specimen with embedded rebars (Halabe et al. 2012)

Figure 3-10 GPR signal comparison between clean (uncorroded) \#5 rebar and corroded \#5 rebar surrounded with moist sand (Halabe et al. 2012).....

Figure 4-1 (a) Steel plates showing connecting wires, (b) Mold for sample 1 showing the steel plates with connecting wires 
Figure 4-2 Sakrete concrete mix.

Figure 4-3 Models of (a) cubes with steel plates and (b) cube with no steel plates (dimensions in inches) .35

Figure 4-4 (a) Taking the weight of a sample (b) Resistance measurement of samples...36

Figure 4-5 Variation of sample weight with time

Figure 4-6 Variation of moisture content with time

Figure 4-7 Variation of electrical resistivity with time 42

Figure 4-8 Variation of electrical resistivity with moisture content. .42

Figure 4-9 Variation of electrical resistivity with moisture content for all four samples 43

Figure 5-1 Final sensor geometry showing embedded steel plates (dimensions in inches)

Figure 5-2 Model of the final electrical resistivity sensor (dimensions in inches)..... 48

Figure 5-3 Actual sensors for (a) laboratory monitoring, (b) field implementation .48

Figure 5-4 Geometry of cube for temperature/humidity sensor (dimensions in inches) ..49

Figure 5-5 RB-Dfr-460 temperature/humidity sensor (RobotShop Inc. 2015) .50

Figure 5-6 A model of the pre-cured concrete cube .50

Figure 5-7 Final temperature/humidity sensor assembly .51

Figure 5-8 Variation of weight with time for samples 5 and 6. .54

Figure 5-9 Variation of moisture content with time .54

Figure 5-10 Variation of sample weight with time during drying .56

Figure 5-11 Moisture content variations for samples 1 through 6. .58

Figure 5-12 Variation of electrical resistivity with time for $R 1$ and $R 2$. 
Figure 5-13 Electrical resistivity versus time comparism for preliminary design and $R 1$, $R 2$.......

Figure 5-14 Variation of electrical resistivity with time

Figure 5-15 Variation of concrete electrical resistivity with moisture content .65

Figure 5-16 Microcontroller for temperature/humidity data collection (SainSmart 2015)

Figure 5-17 (a) Data collection set-up (b) Close-up view of microcontroller connections

Figure 5-18 Variation of temperature within the concrete

Figure 5-19 Variation of relative humidity within the cube. .70

Figure 5-20 Variation of relative humidity with moisture content .71

Figure 5-21 Calibration curve for corrosion data interpretation .73

Figure 5-22 Calibration curve for corrosion data interpretation showing high potential for corrosion zone.

Figure 6-1 (a) and (b) East Lynn Lake Bridge before rehabilitation (USACE 2014) ......77

Figure 6-2 Close-up view of corroded H-piles..... .78

Figure 6-3 Submerged portion of piles free from corrosion damage .78

Figure 6-4 Polymer concrete foundation barrier .79

Figure 6-5 Installation of bottom GFRP shells 80

Figure 6-6 (a) and (b) Resistivity and temperature/humidity sensors installed in East Lynne Bridge columns.

Figure 6-7 Installation of upper FRP shells..... .82

Figure 6-8 Piles being wrapped with GFRP fabric. .83 
Figure 6-9 Pouring self-consolidated concrete.

Figure 6-10 Central monitoring board for data collection

Figure 6-11 East Lynn Lake Bridge after rehabilitation .... .84

Figure 6-12 East Lynn Lake Bridge pile identification plan...... .85

Figure B-1: Soaked samples....................................................................... 106 


\section{LIST OF TABLES}

Table 3-1 Potential reading interpretation guidelines (ASTM C 876) ..........................16

Table 3-2 (a) Guides to concrete resistivity data interpretation (Proceq SA 2012) .........19

Table 3-2 (b) Guides to concrete resistivity data interpretation (Manning 1985) ...........19

Table 3-2 (c) Guides to concrete resistivity data interpretation (Bungey and Millard 1996)

Table 3-2 (d) Guides to concrete resistivity data interpretation (Feliú et al. 1996) ........19

Table 3-3 (a) Corrosion density interpretation guidelines (Andrade \& Alonso 1996, Feliú et al. 1996)

Table 3-3 (b) Corrosion density interpretation guidelines (Broomfield et al. 1993)........24

Table 3-3 (c) Corrosion density interpretation guidelines for 3LP (Clear 1989) ............24

Table 3-4 Comparison between corrosion monitoring techniques ...............................32

Table 4-1 Weight and resistance data for preliminary samples ..................................37

Table 4-2 Summary of extra weights and moisture content .......................................38

Table 4-3 Moisture content and electrical resistivity of the preliminary samples............40

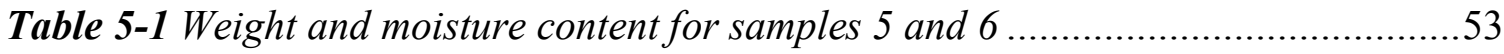

Table 5-2 Moisture content summary table .............................................................56

Table 5-3 Data for resistance sensors during curing ............................................59

Table 5-4 Weight of plates and connectors for samples $R 1$ and $R 2$..........................59

Table 5-5 Summary of weight and electrical resistance data ....................................62

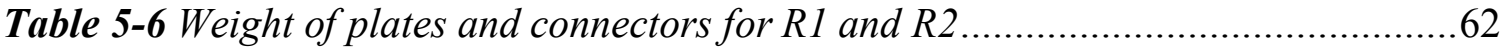

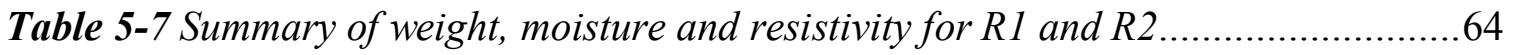

Table 5-8 Summary of temperature/humidity data ................................................68

Table 6-1 Field data for East Lynn Lake Bridge .....................................................87 


\section{ChAPTER 1. INTRODUCTION}

\subsection{BACKGROUND/OVERVIEW}

Reinforced concrete is one of the most widely used construction materials for infrastructure applications across the world due to its reasonable durability and competitive cost. One of the major concerns with reinforced concrete is the deterioration caused by premature corrosion of embedded steel reinforcement under the influence of moisture, chlorides, and oxygen in the field environment (Song and Saraswathy 2007). The need for maintenance and repair of bridges, buildings and other infrastructure for their safety require effective monitoring and evaluation to determine the location and severity/rate of deterioration.

The use of new and advanced materials such as Fiber Reinforced Polymer (FRP) in rehabilitating aging infrastructure as well as in the construction of new ones is on the ascendancy. This is due to FRP having better engineering and desirable properties such as low density, high specific strength and high specific modulus over concrete and steel (GangaRao et al. 2007, Mallick 2007).

Several techniques exist for monitoring corrosion in reinforced concrete. These techniques are primarily based on monitoring of concrete resistivity, corrosion current, moisture content, electric potential, or change in resistance of an embedded element. These techniques were however developed for monitoring corrosion in 'conventional' reinforced concrete structural members, in which the concrete surface is exposed and accessible. The use of FRP shells and/or wraps in rehabilitation and new construction works makes these techniques inapplicable to the structures. Furthermore, most of the available corrosion monitoring techniques require the structural member being monitored to be accessible, which makes them unsuitable for use on certain structures (e.g., underwater members). In case of highway bridge members, traffic control is often needed which results in user inconvenience and increased cost.

Therefore, there is a need to develop an alternative corrosion monitoring techniques that can be adapted to all forms of reinforced concrete structures (both accessible and 
inaccessible components of structures, including conventional reinforced concrete structures and those incorporating FRP products).

A low cost and durable corrosion sensor for embedding inside concrete has been developed in this study. These sensors incorporate electrical resistivity measurements. In addition, commercially available temperature/humidity sensor was also embedded inside concrete. The electrical resistivity and moisture content data were used to develop a methodology for assessing the potential for corrosion of steel encased in concrete structural members. It is important to note that these sensors were made of the same materials that reinforced concrete is made up of, concrete and steel, and therefore do not introduce any weak point in the structure. The sensors were in the form of concrete cubes cured in the laboratory before taking it to the field. Finally, the sensors were installed in the field during construction/rehabilitation work and the wires from the sensors were brought outside to a central monitoring board, so that access to the structural members is not required for data collection.

\subsection{RESEARCH OBJECTIVES}

The primary objectives of this research were to:

- Develop low cost and durable sensors for monitoring corrosion of steel encased in concrete through electrical resistivity measurement

- Utilize commercially available temperature/humidity sensors in addition to the above electrical resistivity sensors for embedding into concrete members

- Use the above sensors to monitor the potential for corrosion of steel encased inside Fiber Reinforced Polymer (FRP) wrapped concrete members

The research objectives were achieved by:

- Designing and producing electrical resistivity sensors in the laboratory, and procuring commercially available temperature/humidity sensors and encasing them in concrete

- Performing laboratory test and developing calibration curves for data interpretation 
- Installing the sensors in the field to monitor the potential for corrosion of steel encased inside FRP wrapped concrete structural columns in East Lynn, West Virginia

\subsection{ORganization}

An overview of the organization of this thesis is as follows:

- Chapter 1

- This chapter gives the overview and outlines the objectives of this research.

- $\quad$ Chapter 2

- The corrosion process of exposed and encased steel is discussed in this chapter. The factors discussed in this chapter includes; the electrochemical nature of corrosion, the factors necessary for corrosion cell to be formed, the effect of carbonation and chloride ion ingress on the corrosion of reinforced concrete.

- Chapter 3

- Some of the most commonly used corrosion monitoring techniques are discussed in this chapter. Details of the chapter include; half-cell potential, concrete resistivity, linear polarization resistance, and embedded sensor techniques. The chapter also highlights the limitations of each of the above techniques.

- Chapter 4

- Preliminary experimental design of the corrosion sensors to determine the appropriate material and sensor geometry is the focus of this chapter. The suitability of plain carbon steel and stainless steel plates embedded inside concrete cubes was evaluated and the magnitudes and changes in moisture content as well as electrical resistance were monitored over time. 
- Chapter 5

○ This chapter focuses on the design of the final sensors. Details of the sensor geometry, laboratory data collection and data analysis are presented in the chapter. Furthermore, the calibration curves for data interpretation for assessing the corrosion potential are developed later in the chapter.

- Chapter 6

○ Field installation of the embedded sensors in the United States Army Corps of Engineers (USACE) East Lynn Lake Bridge is discussed in this chapter. Data obtained from the field sensors and data interpretation to determine the condition of the bridge are presented later in the chapter.

- $\quad$ Chapter 7

- A summary of the scope of work conducted for this study and the key findings are highlighted in this chapter. Finally, the chapter provides recommendations on steps to be taken to ensure easy data collection from sensors installed in field projects.

- Appendix A

- This appendix provides detailed data sets and graphs on the preliminary sensor designs.

- Appendix B

○ Detailed data sets and graphs on the final sensors and laboratory monitoring are provided in this appendix. 


\section{ChAPTER 2. CORROSION OF EXPOSED AND ENCASED STEEL}

\subsection{INTRODUCTION}

The corrosion of reinforcing steel in reinforced concrete structures is a major factor in the deterioration of concrete structures all over the world. "The corrosion of ordinary steel is inevitable" (Carino 2004). This corrosion is a result of iron, the major component of steel, being unstable under normal atmospheric conditions and its natural tendency to revert to the more stable native iron oxide state in the presence of oxygen and water (Carino 2004). The corrosion process of steel is summarized in this chapter.

\subsection{CORROSION OF EXPOSED STEEL}

Exposed steel usually corrodes in the presence of water and oxygen in moist environment. This is a result of the presence of electrical potential difference, either across different locations on the same steel due to non-homogeneity or presence of dirt, or between different steels/metals at different levels on the electrochemical series that are electrically continuous. Corrosion of steel is an electrochemical process which requires four fundamental conditions for the formation of the corrosion cell (Davis 2000).

- An anode - the electron donor (on the steel surface)

- A cathode - the electron acceptor (on the steel surface or different steel/metal)

- A medium for ionic movement (electrolyte)

- An electrical connection between the anode and cathode for electronic movement

The electrochemical corrosion process cannot take place or will be stopped if any of the above conditions is unavailable or disabled. This is the basis for corrosion protection/control of metals (Trethewey and Chamberlain 1995). For corrosion to occur, metal ions at the anode undergo oxidation reaction (also referred to as anodic reaction) to release electrons. These electrons move through the metal or electrical connection between the metals to the cathode where they undergo reduction reactions (also known as cathodic reactions) with oxygen and water to form hydroxyl ions $\left(\mathrm{OH}^{-}\right)$. The hydroxyl ions move 
through the electrolyte and combine with the released metal ions (cations) to form rust. The corrosion process is summarized in Equations 2-1 to 2-5.

Oxidation reaction at the anode

$\mathrm{Fe} \rightarrow \mathrm{Fe}^{2+}+2 \mathrm{e}^{-}$

Reduction reaction at the cathode

$1 / 2 \mathrm{O}_{2}+\mathrm{H}_{2} \mathrm{O}+2 \mathrm{e}^{-} \rightarrow 2 \mathrm{OH}^{-}$

Formation of iron hydroxides at the anode

$\mathrm{Fe}^{2+}+2 \mathrm{OH}^{-} \rightarrow \mathrm{Fe}(\mathrm{OH})_{2}$

$\mathrm{Fe}(\mathrm{OH})_{2}$ further reacts with oxygen and water to produce ferric hydroxide $\left(\mathrm{Fe}(\mathrm{OH})_{3}\right)$ and ferric oxide $\left(\mathrm{Fe}_{2} \mathrm{O}_{3}\right)$

$2 \mathrm{Fe}(\mathrm{OH})_{2}+1 / 2 \mathrm{O}_{2}+\mathrm{H}_{2} \mathrm{O} \rightarrow 2 \mathrm{Fe}(\mathrm{OH})_{3}$

$2 \mathrm{Fe}(\mathrm{OH})_{2}+1 / 2 \mathrm{O}_{2}+\rightarrow \mathrm{Fe}_{2} \mathrm{O}_{3} \cdot 2 \mathrm{H}_{2} \mathrm{O}$

As the metal undergoes oxidation to release electrons and metal ions, weight loss of the metal occurs at the anode, where the corrosion takes place (corrosion products are deposited at the anode). Deposited corrosion product results in volume increase. The corrosion current flows in reverse direction to the flow of electrons and ions (Mehta and Monteiro 1993, Davis 2000) as illustrated in Figure 2-1.

In a functioning electrochemical cell, the anode is positively charged and the cathode is negatively charged. Thus conventional current flows from the anode to the cathode through the electrolyte and from the cathode back to the anode through the electrical path/connection. As stated above, potential/voltage difference is the driving force behind the electrochemical corrosion cell. Hence a DC voltage can be measured between the anode and the cathode in an active corrosion cell. 


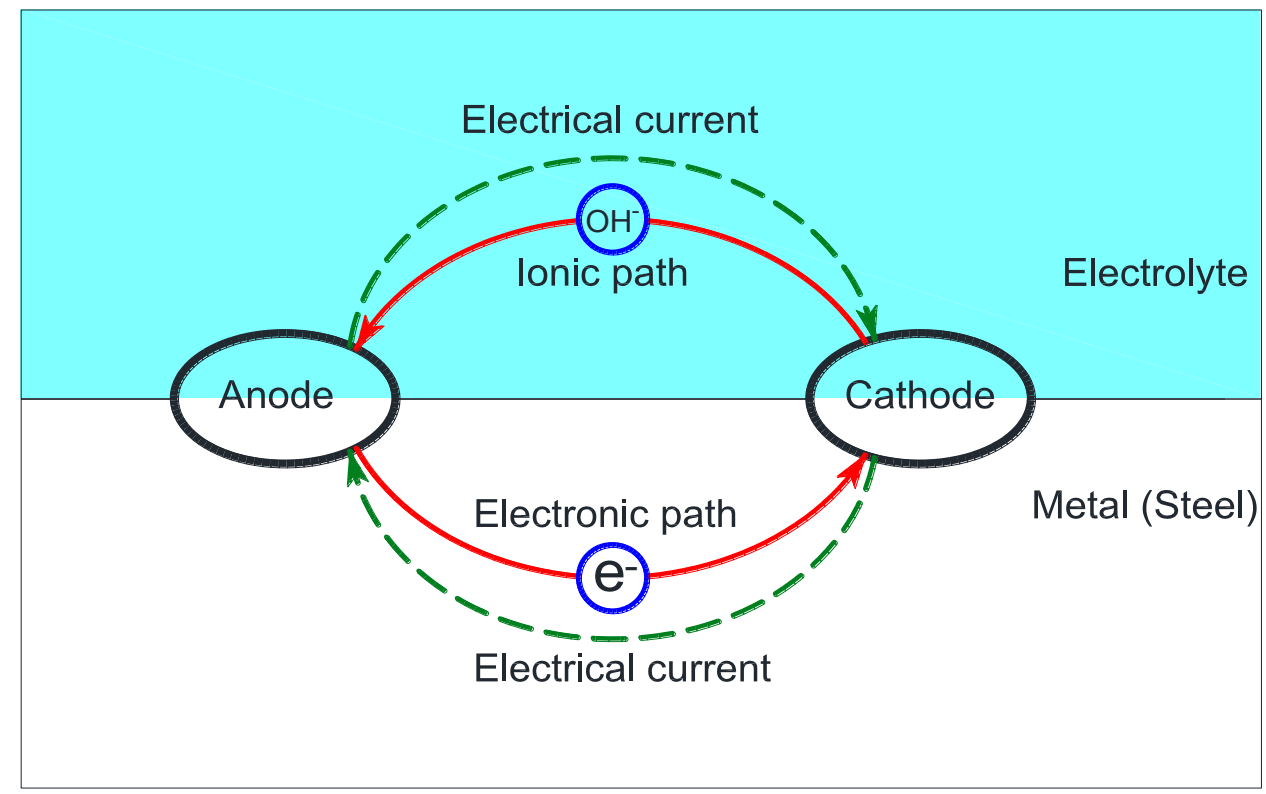

Figure 2-1 Four requirements of an electrochemical corrosion cell

The rate at which a given metal corrodes depends on the balance between all the four components of the corrosion cell. The rate of metal dissolution at the anode in oxidation reaction is controlled by how quickly the electrons generated are consumed by the reduction reaction at the cathode. The presence of electrical resistance in the electronic or ionic current paths will reduce the amount of electrons and ions that move across the cell thereby limiting current flow through the corrosion cell and hence slow down the corrosion process (Davis 2000).

\subsection{CORROSION OF ENCASEd STEEL}

Corrosion of steel encased in concrete such as reinforcing steel is similar to that of exposed steel. However concrete provides both physical and chemical protection against corrosion of the encased steel (Poursaee 2011). Steel in concrete develops a protective passive layer of oxide film that acts as a barrier against corrosion, due to the high alkaline environment ( $\mathrm{pH}$ of about 12.5) provided by the cement paste pores (Carino 2004). The presence of hydroxides of sodium, calcium and potassium produced during the hydration reaction of 
concrete results in its alkaline nature. In a high alkaline environment (such as that provided by a sound concrete), any small break in the protective oxide film is quickly repaired (Ramniceanu 2004) because the ferrous hydroxide $\left(\mathrm{Fe}(\mathrm{OH})_{2}\right.$ ) formed in Equation 2-3 is oxidized to $\gamma$-ferric oxyhydroxide $(\gamma-\mathrm{FeOOH})$.

$$
\mathrm{Fe}(\mathrm{OH})_{2}+1 / 2 \mathrm{O}_{2} \rightarrow \gamma-\mathrm{FeOOH}+\mathrm{H}_{2} \mathrm{O}
$$

$\gamma$-FeOOH provides the tightly adhering protective passive oxide layer on the surface of steel. This passive layer limits the exposure of the steel to moisture and oxygen and hence limits corrosion of the underlying steel (Mindess et al. 2003). However, if the alkalinity $\mathrm{pH})$ of the surrounding concrete is reduced by processes such as carbonation or ingress of chloride ions, the passive oxide film will no longer be maintainable and the steel becomes prone to corrosion (Carino 2004, Ramniceanu 2004).

Carbonation and chloride ion attacks are considered the more likely and dangerous of the various deleterious environmental conditions that reinforced concrete structures are exposed to, with structures in urban and marine environments having the highest risks. Pollution and the use of deicing salts during winter in urban environments, and the effect of sea water in marine environments account for the high risk (Ramezanianpour et al. 2014).

\subsubsection{Carbonation of Reinforced Concrete}

Carbonation of concrete occurs when carbon dioxide $\left(\mathrm{CO}_{2}\right)$ from the air or water penetrates into concrete and reacts with the alkalis in its pore solution. Once inside concrete, $\mathrm{CO}_{2}$ may combine with existing water and form carbonic acid $\left(\mathrm{H}_{2} \mathrm{CO}_{3}\right)$ before reacting with alkali hydroxides of calcium, potassium and sodium to form carbonates according to the following reactions (Chávez-Ulloa et al. 2013, Ramezanianpour et al. 2014).

$\mathrm{CO}_{2}+\mathrm{H}_{2} \mathrm{O} \rightarrow \mathrm{H}_{2} \mathrm{CO}_{3}$ 
Hydroxyl ions $\left(\mathrm{OH}^{-}\right)$are consumed in the reactions above, thereby lowering the alkalinity/pH of concrete pore solution, resulting in the breakdown of the protective passive film on steel. As the $\mathrm{pH}$ of concrete is reduced by carbonation, the concentration of chloride ions required to promote corrosion will be reduced accordingly. When the passive film is broken at $\mathrm{pH}$ below 11.5 , the availability of moisture and oxygen will be enough to promote corrosion and no chloride ions will be needed.

The rate of carbonation in concrete is affected by factors such as relative humidity, water/cement ratio and porosity of concrete. Relative humidity of $25 \%-75 \%$ is the ideal range for carbonation. The rate of carbonation is considered insignificant for humidity below $25 \%$, and absorption of $\mathrm{CO}_{2}$ by concrete is restricted by moisture in the pores for humidity higher than 75\%. "Carbonation-induced corrosion often occurs in regions that are exposed to rainfall, shaded from sunlight, and have low concrete cover over the reinforcing steel" (Xing et al. 2010).

Researches by Yoon (2007) and Ramezanianpour et al. (2014) respectively found out that carbonation depths and carbon dioxide consumptions increase with increasing water/cement ratios.

Carbonation is said to be a slow process as compared to corrosion induced by chloride ion attack, and has other effects on concrete properties such as increase in compressive strength, reduction in porosity, shrinkage and development of cracks.

\subsubsection{Effect of Chloride Ions}

According to Mehta and Monteiro (1993), the protective passive oxide film on the steel will be stable provided the $\mathrm{pH}$ of the concrete pore solution stays above 11.5 in the absence 
of chloride ions. However, when chloride ions are present in concrete, the passive film may be destroyed even at $\mathrm{pH}$ values above 11.5. Mehta and Monteiro (1993) further found out that, once the passive film over the embedded steel is destroyed, electrical resistivity of concrete and the presence of oxygen become the controlling forces affecting the corrosion rate. However, concrete tends to retain more moisture at high chloride ion content, which reduces the electrical resistivity and hence increases the rate of corrosion.

Chlorides can get into concrete from various sources such as deicing salts, sea and ground water, concrete admixtures, and contaminated aggregates/water. A sound, non-carbonated concrete will only corrode if the chloride ion content at the steel surface reaches a certain threshold value referred to as the critical chloride content or chloride threshold value. Critical chloride content is defined in two ways, which in addition to other factors account for a wide range of threshold values reported in literature. The critical chloride content is defined scientifically as "the chloride content required for depassivation of the steel (definition 1)". Depassivation may however not lead to corrosion in dry concrete, hence from engineering perspective, the critical chloride content is practically defined as "the chloride content associated with visible or acceptable deterioration of the structure (definition 2)" (Schiessl \& Lay 2005, Angst \& Vennesland 2009). The above definitions are illustrated in Figure 2-2. 


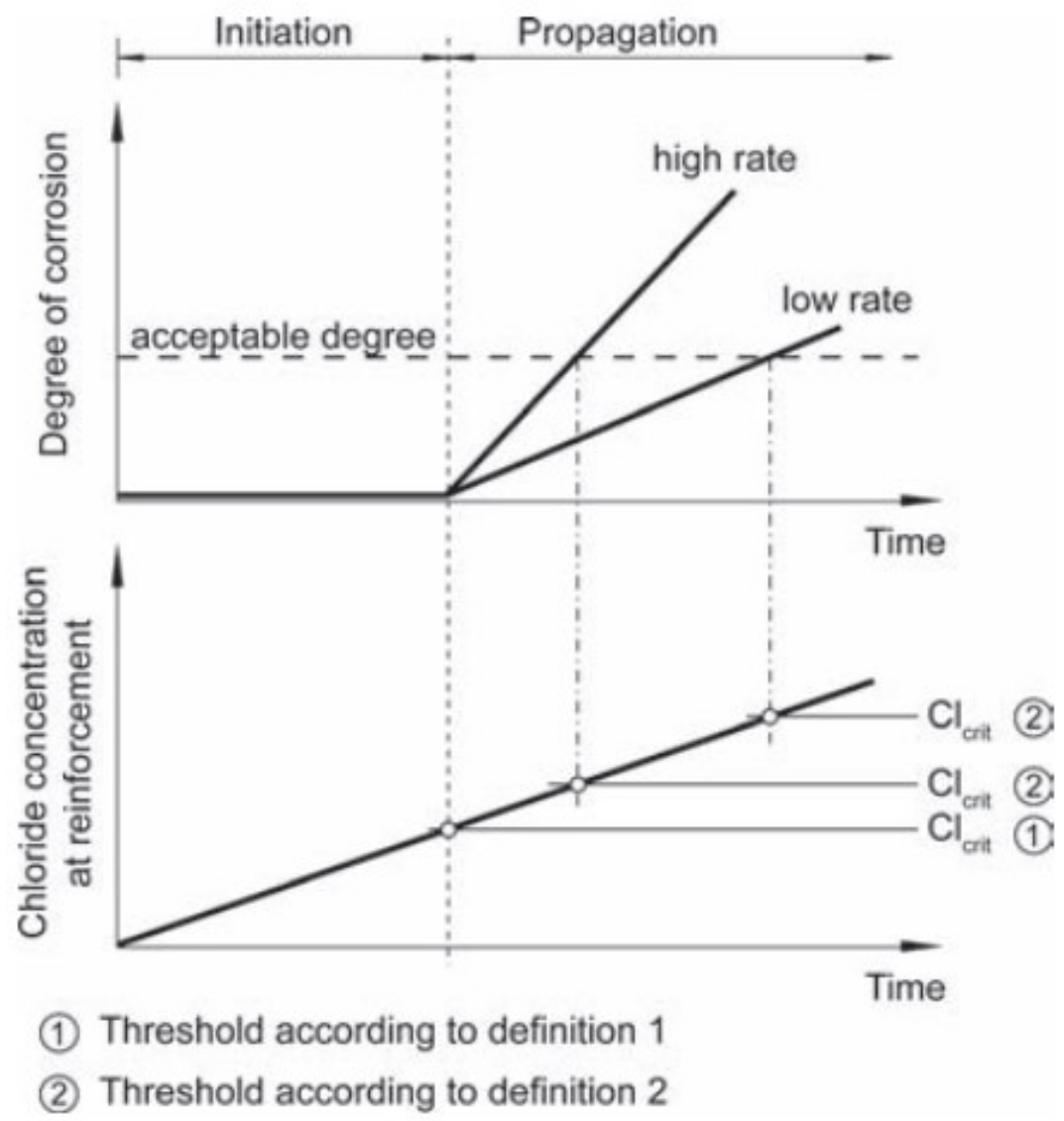

Figure 2-2 Different definitions for critical chloride content (Angst \& Vennesland 2009)

Chlorides that reach the steel surface react with iron ions in the passivating layer of steel to form iron-chloride complex, which later hydrolyzes with water to form loose porous rust according to the following equations (Mindess et al. 2003, Xing et al. 2010).

$\mathrm{Fe}^{2+}+\mathrm{Cl}^{-} \rightarrow[\mathrm{FeCl} \text { complex }]^{+}$

$[\mathrm{FeCl} \text { complex }]^{+}+2 \mathrm{OH}^{-} \rightarrow \mathrm{Fe}(\mathrm{OH})_{2}+\mathrm{Cl}^{-}$

The chloride is released at the end of the reaction and the $\mathrm{pH}$ of the concrete is reduced by the consumption of $\mathrm{OH}$ ions. As the $\mathrm{pH}$ is reduced, lower amount of chloride is required to promote corrosion. 
Chlorides are directly responsible for the initiation of corrosion. However, they appear to play only an indirect role in the rate of corrosion after initiation. The primary factors controlling the corrosion rate are the availability of oxygen, the electrical resistivity, the relative humidity of the concrete, the $\mathrm{pH}$ of the pore solution, and the temperature (Xing et al. 2010).

Thus the protection provided by the alkalinity of concrete against corrosion can be breached by either carbonation, chloride ion attack or a combination of the two. The combined attack of carbonation and chloride ion ingress is however more common in practical civil engineering infrastructure, and the interaction between the two processes help accelerate the deterioration process as illustrated in Figure 2-3.

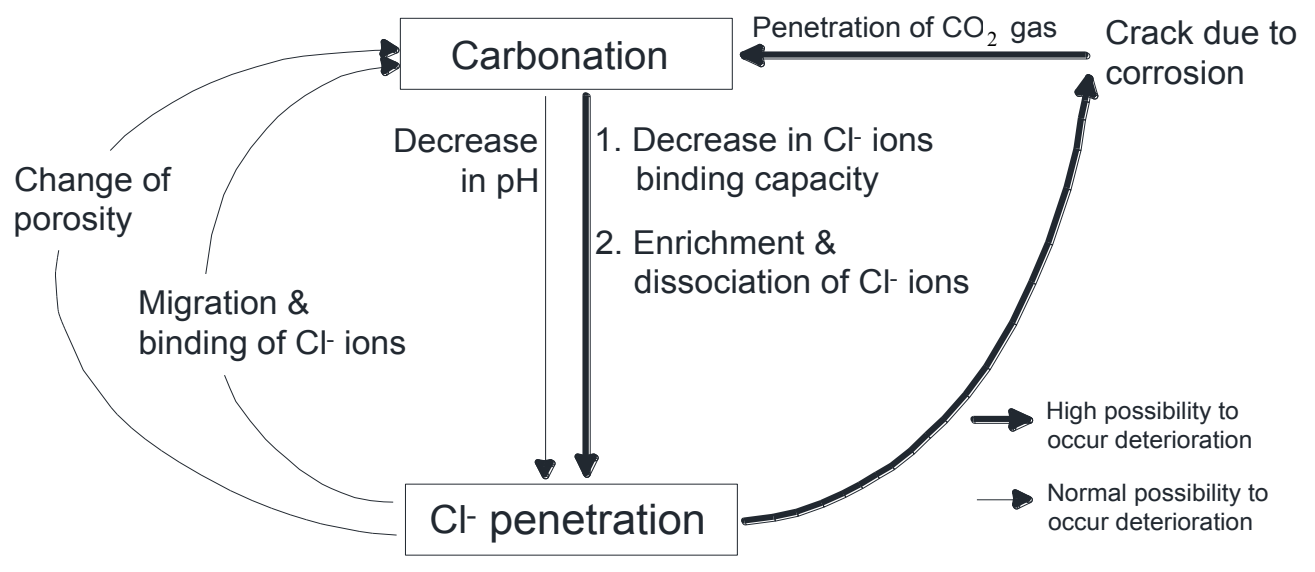

Figure 2-3 Mechanism of interaction between carbonation and chloride penetration (Yoon 2007)

Once the passive layer protecting the steel is broken, the presence of moisture and oxygen controls the corrosion process. It has been documented by several researchers, including Bastidas-Arteaga and Stewart (2013), Li et al. (2009), and Shetty (2005), that the optimal relative humidity for corrosion in reinforced concrete is $70-80 \%$.

In concrete, the anode and cathode may be on the same steel reinforcement (microcell corrosion) or on different pieces of reinforcement (macrocell corrosion). The concrete acts 
as the electrolyte while the steel/steel chair/ties connects the anode and cathode electrically. The corrosion of encased steel in concrete is summarized in Figure 2-4.

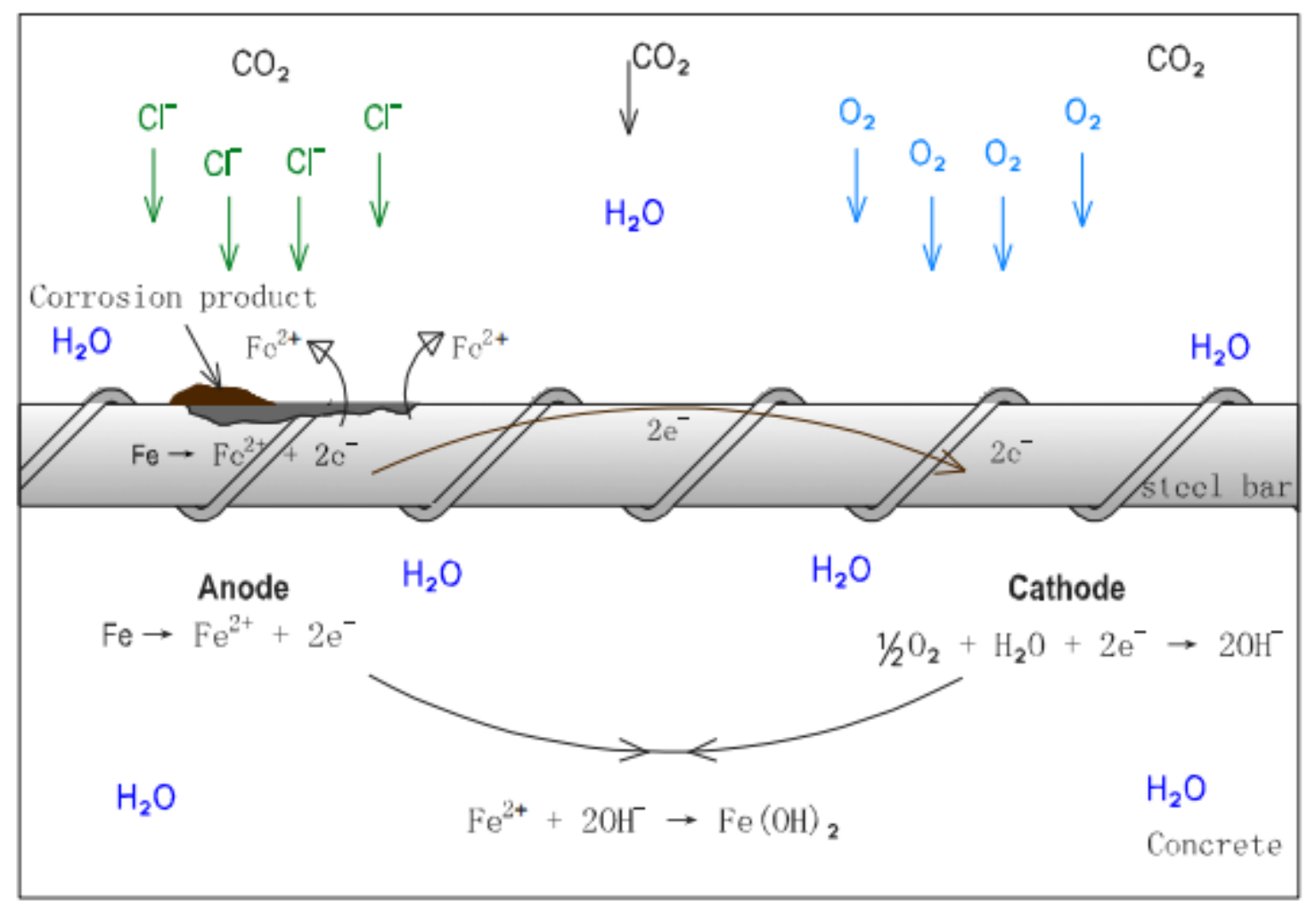

Figure 2-4 Corrosion of encased steel

Deposited corrosion product can be as high as six times the volume of the original steel (Mehta and Monteiro 1993), which results in cracking and subsequent spalling of surrounding concrete. Thus, once corrosion is initiated, the process continues rapidly because cracked and/or spalled concrete enables easy access of corrosive agents to the steel and maintains the vicious cycle.

\subsection{Conclusions}

The corrosion process of exposed and encased steel is summarized in this chapter. The corrosion monitoring techniques are discussed in subsequent chapters of this thesis. 


\section{Chapter 3. CORrosion Monitoring TeChNiQues}

\subsection{INTRODUCTION}

"Reinforced concrete structures have the potential to be very durable and capable of withstanding a variety of adverse environmental conditions" (Song and Saraswathy 2007). However, corrosion of reinforcing steel in concrete still occurs, and is the major factor accounting for premature deterioration and subsequent failures in reinforced concrete structures (Song and Saraswathy 2007, Li et al. 2006). This is more prevalent in structures exposed to adverse environmental conditions without adequate protection. These structures therefore require continuous maintenance and repair to ensure their safety and durability.

Structural maintenance can only be carried out appropriately with adequate monitoring and measurement of deterioration. Structural monitoring ensures that sufficient data is obtained on the location and severity/rate of deterioration, hence enabling the right maintenance activity to be carried out on the structure at the right location and at the time when it is most efficient. Thus corrosion monitoring results in lower maintenance costs and "also helps to develop durability models and related predictive techniques to enhance the understanding of macrocell corrosion environments" (Xing et al. 2010).

Several methods are available for corrosion monitoring, most of which rely on the electrochemical nature of corrosion. Some of the commonly used methods are discussed below.

\subsection{Half-Cell Potential Method}

Half-cell potential method is the most common and widely used technique in evaluating rebar corrosion in concrete (Poursaee 2011). The principles of an active electrochemical corrosion as described in Chapter 2 create a potential difference across the surface of reinforced concrete. This potential can be measured with a standard reference electrode such as copper-copper sulfate electrode (CSE), and the readings give the likelihood of an active corrosion. The apparatus consists of a copper rod immersed in a saturated copper sulfate solution (copper-copper sulfate half-cell), connecting wires and a high impedance 
voltmeter to take the readings (Carino 2004). The test is standardized by ASTM C 876, "Standard Test Method for Corrosion Potentials of Uncoated Reinforcing Steel in Concrete". The apparatus and test setup is illustrated in Figure 3-1 as described in the standard.

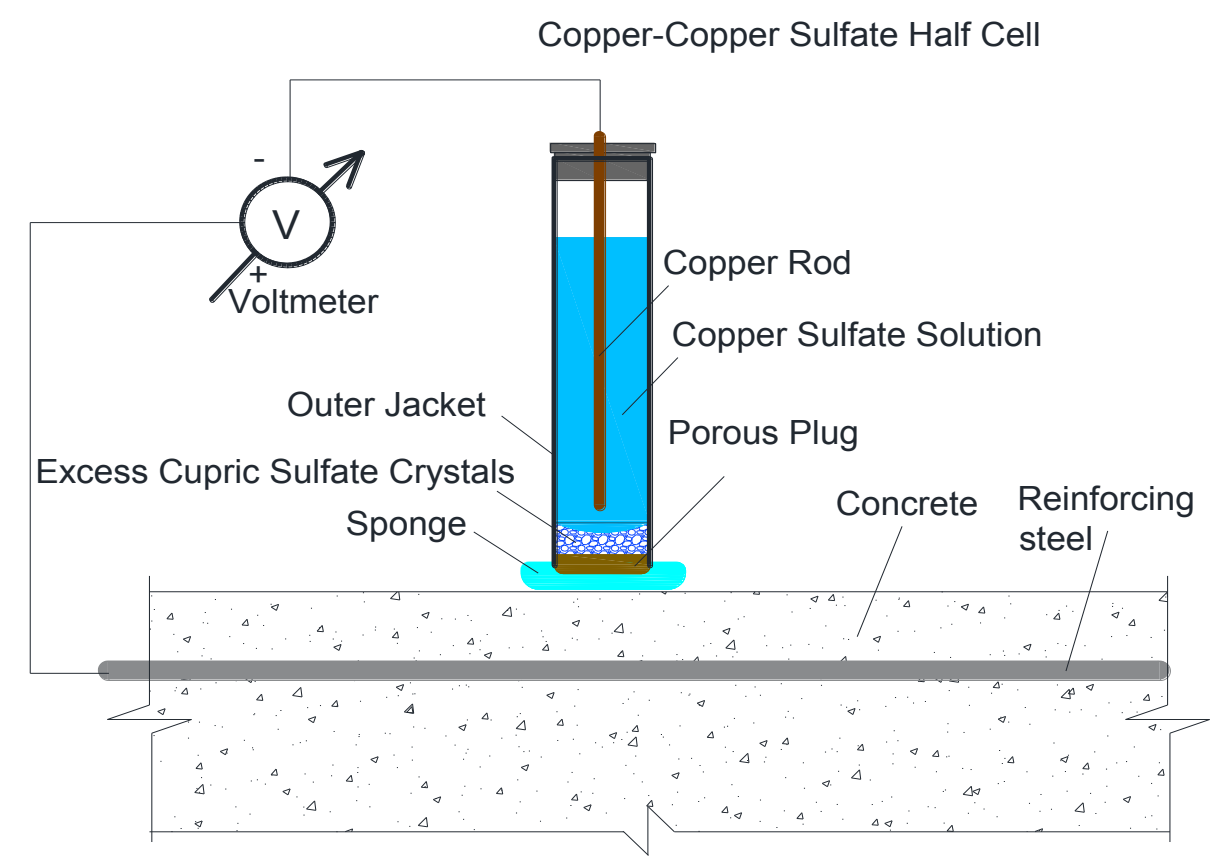

Figure 3-1 Half-cell potential apparatus

"The half-cell potential readings [at any point on the concrete surface] are indicative of the probability of corrosion activity of the reinforcing steel located beneath the copper-copper sulfate reference cell" (Carino 2004). The above statement is best explained by Figure 3-2 as illustrated in the 'Canin corrosion analyzing instrument' operating instructions by Proceq SA.

ASTM C 876 gives two techniques that can be used to evaluate the test data: Numeric Magnitude Technique or Potential Difference Technique or a combination of the two. The following table gives the guidelines for interpreting the data with the numeric magnitude technique. The voltages listed are referenced to the copper-copper sulfate reference electrode. 


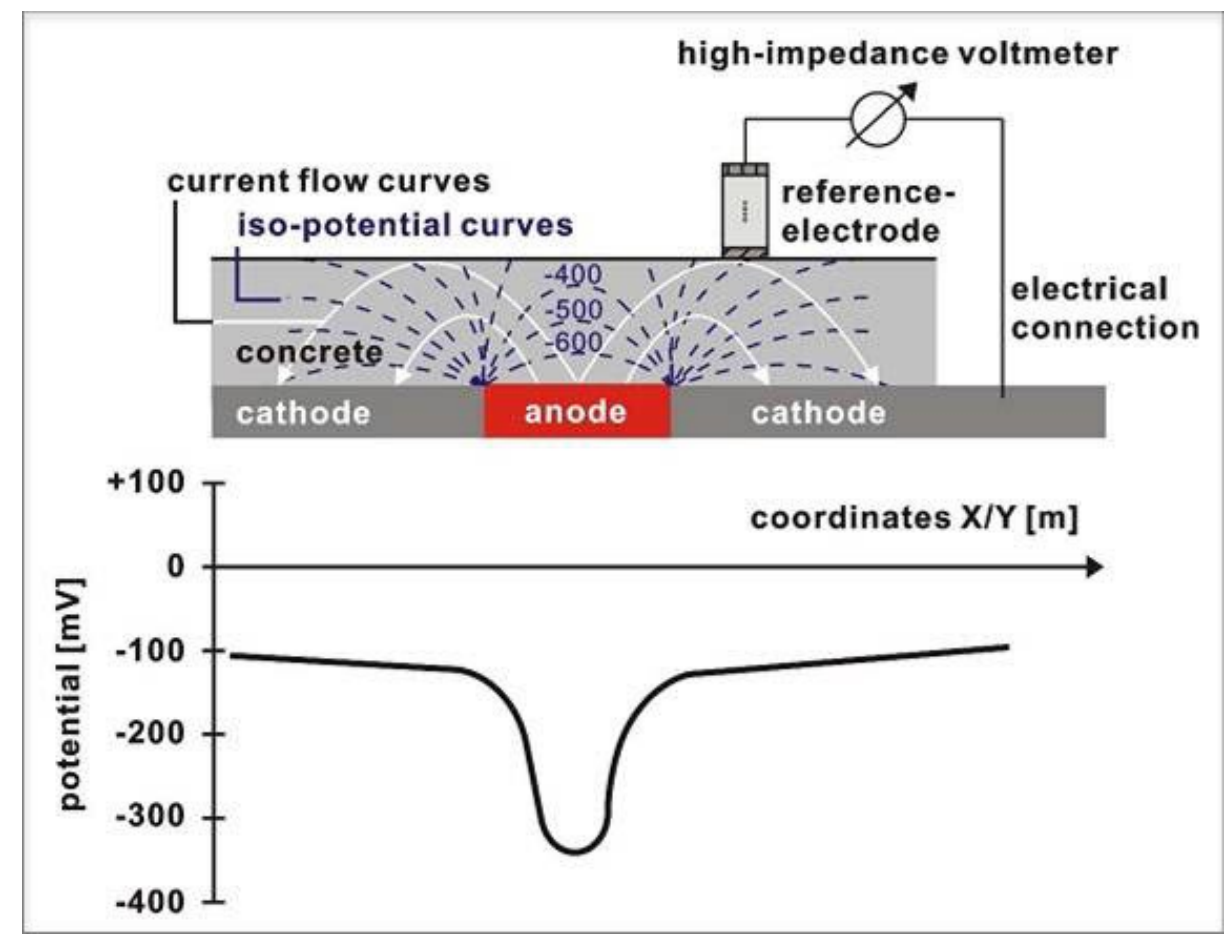

Figure 3-2 Illustration of half-cell potential readings (Proceq SA 2012)

Table 3-1 Potential reading interpretation guidelines (ASTM C 876)

\begin{tabular}{|l|l|}
\hline \multicolumn{1}{|c|}{ Voltmeter Reading } & \multicolumn{1}{c|}{ Interpretation } \\
\hline More positive than $-200 \mathrm{mV}$ & Greater than $90 \%$ probability of no active corrosion \\
\hline Between $-200 \mathrm{mV}$ and $-350 \mathrm{mv}$ & Corrosion activity uncertain \\
\hline More negative than $-350 \mathrm{mV}$ & Greater than $90 \%$ probability of active corrosion \\
\hline
\end{tabular}

Other reference electrodes such as silver-silver chloride electrode and saturated calomel electrode (SCE) can be used in place of the CSE and techniques are available to convert the measured potential to CSE equivalent. 


\subsubsection{Limitations of Half-Cell Potential Method}

The half-cell potential method determines the probability of an active corrosion at the time of test and not the actual rate of corrosion or the level of the corroded steel. In addition, the test requires electrical connection to the reinforcing steel and access to the concrete surface, which can be problematic at times. The test is also affected by several factors (Abu Yosef et al. 2012b), and for this reason ASTM C 876 recommends that potential readings be supplemented with other data such as chloride contents, depth of carbonation and delamination survey findings. This method is also considered inapplicable to "concrete with epoxy-coated reinforcement or concrete with coated surfaces" (Carino 2004).

\subsection{Concrete Resistivity Method}

It has already been discussed in Chapter 2 that the availability of oxygen (for cathodic reaction) and moisture controls the corrosion rate once the passivity of concrete is broken. The availability of moisture affects electrical resistance of the concrete, which controls the rate at which ions move between the anode and cathode of a corrosion cell through the concrete and hence the rate of corrosion. Concrete with high electrical resistivity has a slower corrosion rate as compared to concrete with low resistivity in which current can flow between the anode and cathode with ease (Song and Saraswathy 2007).

The most common method of measuring concrete resistivity is by using the Wenner probe, which was originally developed to measure soil resistivity. It consists of four equally spaced, collinear probes that should be connected to the concrete electrically. To measure the resistivity of concrete, a known current is circulated through the two outermost probes and the resulting potential, which is used to determine the resistance, is measured between the two inner probes (Simon and Vass 2012, Song and Saraswathy 2007). The test setup is illustrated schematically in Figure 3-3.

Resistivity of concrete is then calculated using the following equation:

$$
\rho=2 \pi s \frac{V}{I}
$$


Where:

$\rho=$ electrical resistivity $\mathrm{k} \Omega . \mathrm{cm})$

$\mathrm{s}=$ the spacing between the probes $(\mathrm{cm})$

$\mathrm{I}=$ the applied current $(\mu \mathrm{A})$

$\mathrm{V}=$ the measured potential $(\mathrm{mV})$
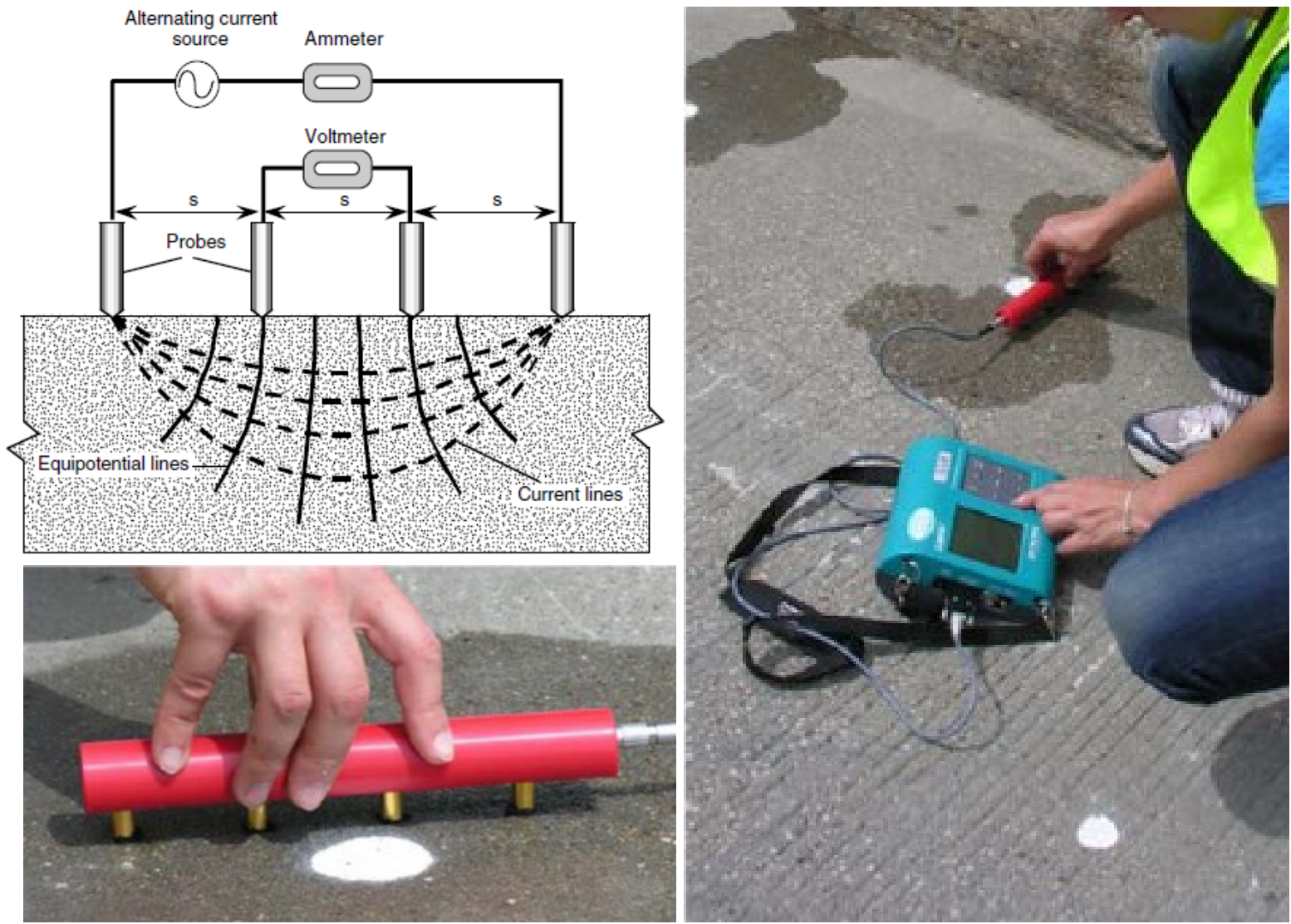

Figure 3-3 The four point Wenner probe (top left, Carino 2004), and Wenner probe testing on a bridge deck (bottom left and right, from Gucunski et al. 2009)

Currently, there is no ASTM standard for this test in concrete (standard is under development, and AASHTO has specifications on electrode spacing) but several recommendations for data interpretation have emerged. These recommendations are presented in Table 3-2 (a-d).

Proceq gives the following guidelines for data interpretation in the operating instructions for its Canin + device. 
Table 3-2 (a) Guides to concrete resistivity data interpretation (Proceq SA 2012)

\begin{tabular}{|l|l|}
\hline Resistivity, $\mathrm{k} \Omega \mathrm{cm}$ & Corrosion Risk \\
\hline$\rho \geq 12$ & Corrosion is unlikely \\
\hline$\rho=8$ to 12 & Corrosion is possible \\
\hline$\rho \leq 8$ & Corrosion is fairly certain \\
\hline
\end{tabular}

Which is similar to what Manning (1985) recommended.

Table 3-2 (b) Guides to concrete resistivity data interpretation (Manning 1985)

\begin{tabular}{|l|l|}
\hline Resistivity, $\mathrm{k} \Omega \mathrm{cm}$ & Corrosion Risk \\
\hline$\rho>12$ & Corrosion is unlikely \\
\hline$\rho=5$ to 12 & Corrosion is possible \\
\hline$\rho<5$ & Corrosion is certain \\
\hline
\end{tabular}

Bungey and Millard (1996) also recommended

Table 3-2 (c) Guides to concrete resistivity data interpretation (Bungey and Millard 1996)

\begin{tabular}{|l|l|}
\hline Resistivity, $\mathrm{k} \Omega \mathrm{cm}$ & Corrosion Risk \\
\hline$\rho>20$ & Low corrosion rate \\
\hline$\rho=10$ to 20 & Low to moderate corrosion rate \\
\hline$\rho=5$ to 10 & High corrosion rate \\
\hline$\rho<5$ & Very high corrosion rate \\
\hline
\end{tabular}

Whereas Feliú et al. (1996) compared resistivity to $I_{c o r r}$ values and recommended

Table 3-2 (d) Guides to concrete resistivity data interpretation (Feliú et al. 1996)

\begin{tabular}{|l|l|}
\hline Resistivity, $k \Omega \mathrm{cm}$ & Corrosion Risk \\
\hline$\rho>100$ to 200 & Negligible corrosion, or concrete too dry \\
\hline$\rho=50$ to 100 & Low corrosion rate \\
\hline$\rho=10$ to 50 & Moderate to high corrosion rate \\
\hline$\rho<10$ & Resistivity does not control corrosion rate \\
\hline
\end{tabular}




\subsubsection{Limitations of Concrete Resistivity Method}

Equation 3-1 was derived by Wenner under the assumption that the material is semi-infinite and homogeneous. The above assumptions therefore needs to be satisfied in order to obtain a correct measure of resistivity and any deviations leads to differences between the calculated (or measured) and true value of material resistivity (Carino 2004).

Millard et al. (1990) studied the differences between the calculated and true value of material resistivity when Equation 3-1 is applied to a material of finite geometry, and recommended the following conditions be met to ensure that the calculated resistivity is a good approximation of the actual value;

a. Electrode spacing should normally be at least $50 \mathrm{~mm}$

b. The width and depth of the member should be at least four times the electrode spacing

c. The edge distance should not be less than twice the electrode spacing

The calculated resistivity will exceed the actual value if the above conditions are not satisfied.

In addition, factors such as the presence of thin layer of low resistivity concrete at the surface and presence of reinforcing bars close to the probes affect the value of calculated resistivity. These factors result in the calculated value being lower than the actual resistivity. Millard et al. (1990) recommends that, resistivity measurements be carried out midway between two rebars to minimize this error if it is not negligible.

Finally, the concrete resistivity method requires access to the surface of the reinforced concrete member, which is not feasible in certain situations.

\subsection{Linear Polarization Resistance Method}

The linear polarization resistance (LPR) is one of the commonly available non-destructive methods of measuring corrosion rate of reinforcing steel in concrete. Unlike the half-cell potential measurement which only gives the probability of active corrosion, this method 
provides instantaneous corrosion rate of steel reinforcement. It thus enables a more detailed structural condition assessment to be carried out. The above statement is well echoed by Feliú et al. (1996) when they concluded "methods based on linear polarization technique are the most suitable to be applied on-site." An analysis by Li et al. (2006) and a review by Otieno et al. (2010) also provided corrosion rate as one of the most important input parameters in corrosion-induced damage models.

To carry out corrosion measurement using this method, the reinforcing steel is electrically perturbed by a small amount from its equilibrium potential. Two methods exist for perturbing the steel; either by changing the potential of the reinforcing steel by a fixed amount, $\Delta E$, and monitoring the current decay, $\Delta I$, or by applying a fixed current, $\Delta I$ to the reinforcing steel and monitoring the potential change, $\Delta E$ (Song et al. 2007).

The linear relationship between the change in voltage, $\Delta E$, and the change in current per unit area of electrodes, $\Delta i$, results in the ratio called the polarization resistance, $R_{p}$ (in ohm$\mathrm{cm}^{2}$ ) (Carino 2004).

$R_{p}=\frac{\Delta E}{\Delta i}$

The instantaneous corrosion rate or corrosion current density, $i_{\text {corr }}$ (in $\mu \mathrm{A} / \mathrm{cm}^{2}$ ), is then calculated from the linear polarization resistance using the Stern-Geary equation (Equation 3-3).

$i_{\text {corr }}=\frac{B}{R_{p}}$

$B=\frac{\left(\beta_{a} \beta_{c}\right)}{2.3\left(\beta_{a}+\beta_{c}\right)}$

Where:

$\mathrm{B}=$ Stern-Geary constant, $\mathrm{mV}$

$\beta_{a}=$ anodic Tafel constant, $\mathrm{mV} /$ decade

$\beta_{c}=$ cathodic Tafel constant, $\mathrm{mV} /$ decade 
The Stern-Geary constant may range from $13 \mathrm{mV}$ to $52 \mathrm{mV}$ depending on the metalelectrolyte system, but a value of $26 \mathrm{mV}$ has been found to be accurate for active reinforcing steel in concrete by taking both the anodic and cathodic Tafel constants to be 120mV/decade (Xing et al. 2010, Stern and Weisert 1958, Lambert et al. 1991, Feliú et al. 1996, Broomfield 1997, McDonald et al. 1998).

The corrosion rate in terms of penetration, (CR), in $\mathrm{mm} / \mathrm{year}$ can be calculated from corrosion current densities using Faraday's law (ASTM G102-89). This can be achieved by using Equation 3-5 (ASTM G102-89, ASTM G59-97, Dean et al. 1971).

$C R=3.27 \times 10^{-3} \frac{i_{\text {corr EW }}}{\rho}$

Where:

$\mathrm{EW}=$ equivalent weight of corroding species, $\mathrm{g}$

$\rho=$ density of corroding material, $\mathrm{g} / \mathrm{cm}^{3}$

The most conventional method for measuring the polarization resistance of reinforcing steel in concrete is by the three electrode system, often referred to as the 3LP device. It is however difficult to determine the exact area of reinforcing steel that is affected by the current and a modified version of the device with a fourth (guard) electrode has been developed.

The guard electrode is used to regulate and confine the applied current to a known path. This ensures a more accurate determination of affected steel area, which is located approximately under the counter electrode (Carino 2004). An example of this instrument is show in Figure 3-4. The method is rapid and instantaneous, and requires electrical connection to the reinforcing steel. 


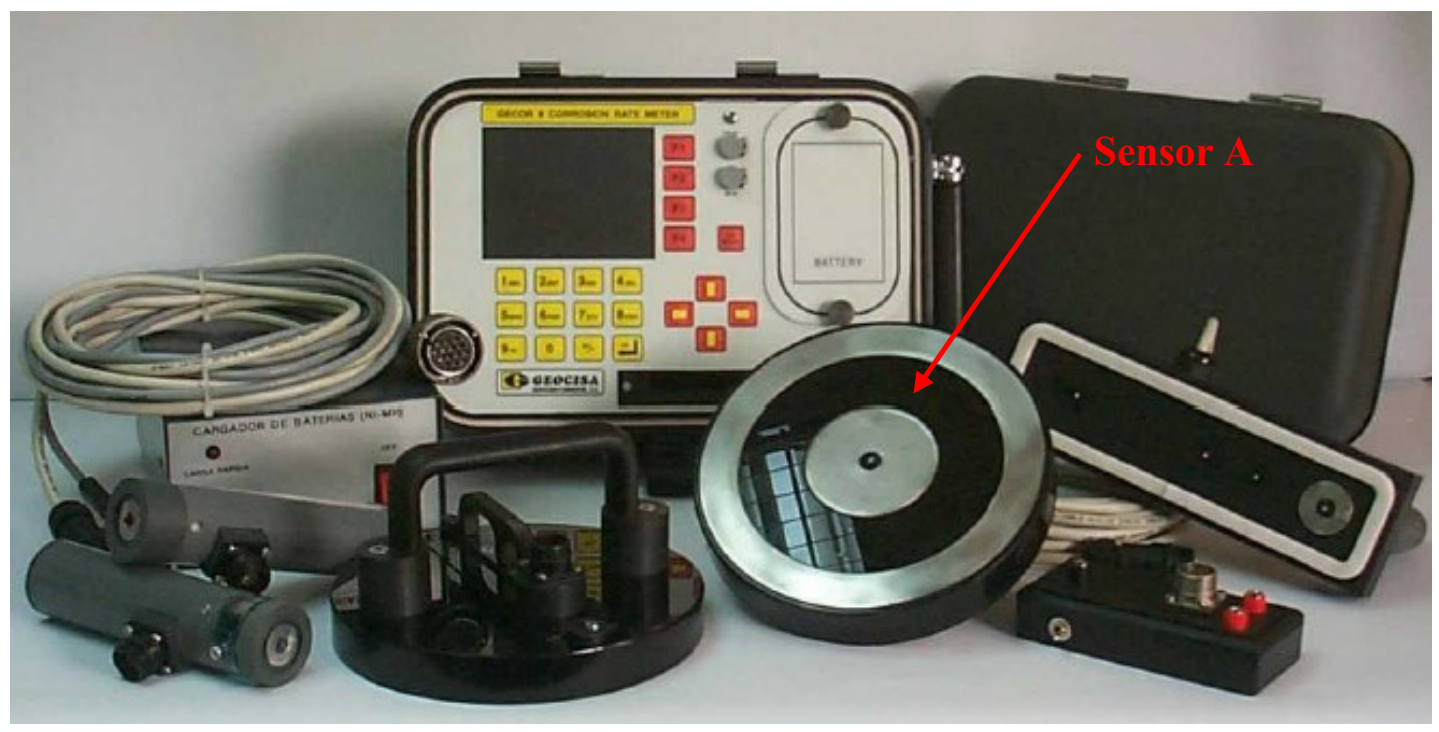

Figure 3-4 Linear polarization instrument (James Instruments 2002)

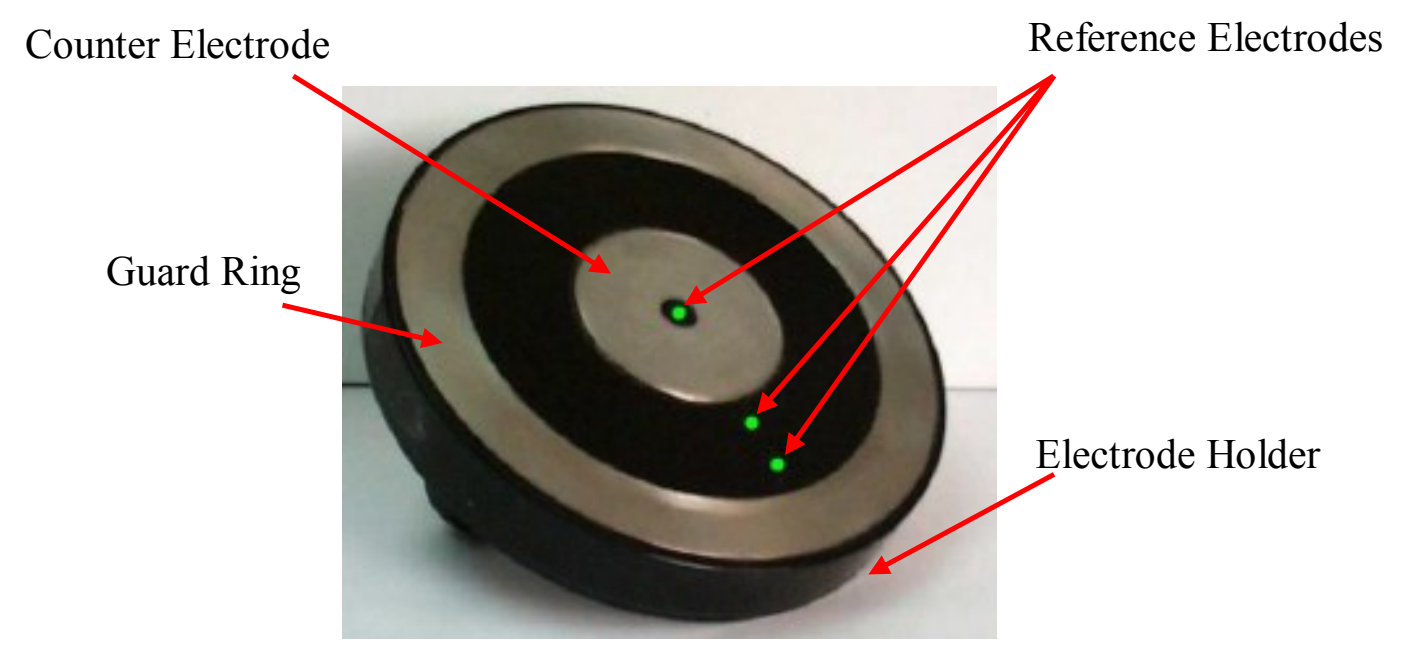

Figure 3-5 Details of Sensor A (James Instruments 2002, USDOT 2015)

A study involving laboratory and field tests was conducted by Andrade and Alonso (1996) as well as Feliú et al. (1996). Based on their observations, they developed the following guidelines for interpreting the corrosion rate data using the device with guard electrode [Table 3-3 (a) - 3-3 (c)]. 
Table 3-3 (a) Corrosion density interpretation guidelines (Andrade \& Alonso 1996, Feliú et al. 1996)

\begin{tabular}{|l|l|}
\hline $\begin{array}{c}\text { Corrosion Current Density }\left(i_{\text {corr }}\right), \\
\mu \mathrm{A} / \mathrm{cm}^{2}\end{array}$ & Corrosion Risk \\
\hline$<0.1$ & Negligible \\
\hline 0.1 to 0.5 & Low \\
\hline 0.5 to 1 & Moderate \\
\hline$>1$ & High \\
\hline
\end{tabular}

The above guidelines are similar to what was developed earlier by Broomfield et al. (1993) from field and laboratory investigations.

Table 3-3 (b) Corrosion density interpretation guidelines (Broomfield et al. 1993)

\begin{tabular}{|l|l|}
\hline $\begin{array}{c}\text { Corrosion Current Density }\left(i_{\text {corr }}\right), \\
\mu \mathrm{A} / \mathrm{cm}^{2}\end{array}$ & Corrosion Risk \\
\hline$<0.1$ & Passive condition \\
\hline 0.1 to 0.5 & Low to moderate corrosion \\
\hline 0.5 to 1 & Moderate to high corrosion \\
\hline$>1$ & High corrosion rate \\
\hline
\end{tabular}

The following table gives the guidelines for interpreting results from the device without guard electrode (Clear 1989).

Table 3-3 (c) Corrosion density interpretation guidelines for 3LP (Clear 1989)

\begin{tabular}{|l|l|}
\hline $\begin{array}{c}\text { Corrosion Current Density }\left(i_{\text {corr }}\right), \\
\mu \mathrm{A} / \mathrm{cm}^{2}\end{array}$ & Corrosion Risk \\
\hline$<0.2$ & No corrosion damage expected \\
\hline 0.2 to 1.0 & Corrosion damage possible in $10-15$ years \\
\hline 1.0 to 10 & Corrosion damage expected in 2-10 years \\
\hline$>10$ & Corrosion damage expected $<2$ years \\
\hline
\end{tabular}




\subsubsection{Limitations of Linear Polarization Method}

As has been discussed above, corrosion current densities can be converted to corrosion rate (metal loss) by using Faraday's law. This results in about $0.012 \mathrm{~mm} /$ year of metal loss from $1 \mu \mathrm{A} / \mathrm{cm}^{2}$ corrosion current density (Broomfield et al. 1993). This computation however assumes that the rebar is corroding uniformly. The above assumption is a typical condition with carbonation induced corrosion, but chloride induced corrosion is characterized by localized/pitting corrosion (Carino 2004) which can result in errors in the corrosion rate calculation.

Corrosion current density is calculated using the constant $\mathrm{B}$, which is typically assumed to be $26 \mathrm{mV}$ for active rebars. This constant can be as high as two times the above value for passive rebars as pointed out by Feliú et al. (1996), resulting in a level of uncertainty in the calculated corrosion rate.

Finally, the linear polarization resistance measurement requires access to the surface of the reinforced concrete and the rebar, which is not feasible in certain situations.

\subsection{EMBEDDED CORROSION SENSORS}

To address some of the limitations associated with the corrosion monitoring techniques discussed in the previous sections, different types of embedded sensors for corrosion monitoring have been developed. Two of these sensors are discussed below.

\subsubsection{VTI ECI Corrosion Monitoring Device}

The Embedded Corrosion Instrument (ECI), Figure 3-6, was developed by Virginia Technologies, Incorporated (VTI). This device is capable of monitoring five key factors affecting the corrosion of reinforced concrete structures (Virginia Technologies, Inc.), thus providing data on a variety of corrosion related factors - electrical potential, concrete resistivity, linear polarization resistance, chloride ion concentration trend, and temperature as discussed in previous sections. 
Combined monitoring of these factors will give a more comprehensive data and enable the relative condition of the structure to be evaluated over time, thus providing a more certain picture of corrosion threat.

The embedded device gathers and transmits the corrosion data to an external datalogger through wired connection. From the external datalogger, the data can be downloaded through wireless transceiver or cellular modem (Virginia Technologies, Inc.).

Though the available literature on the implementation and performance of this sensor is limited, an evaluation by Reis and Gallaher (2006) found out that the results obtained using this sensor is consistent with other conventional methods.

However, long term evaluations need to be done to determine the long term durability and performance of the sensor in an actual concrete service environment. Additional work is also required to improve the reliability of chloride and resistivity measuring sensors (Reis and Gallaher 2006).

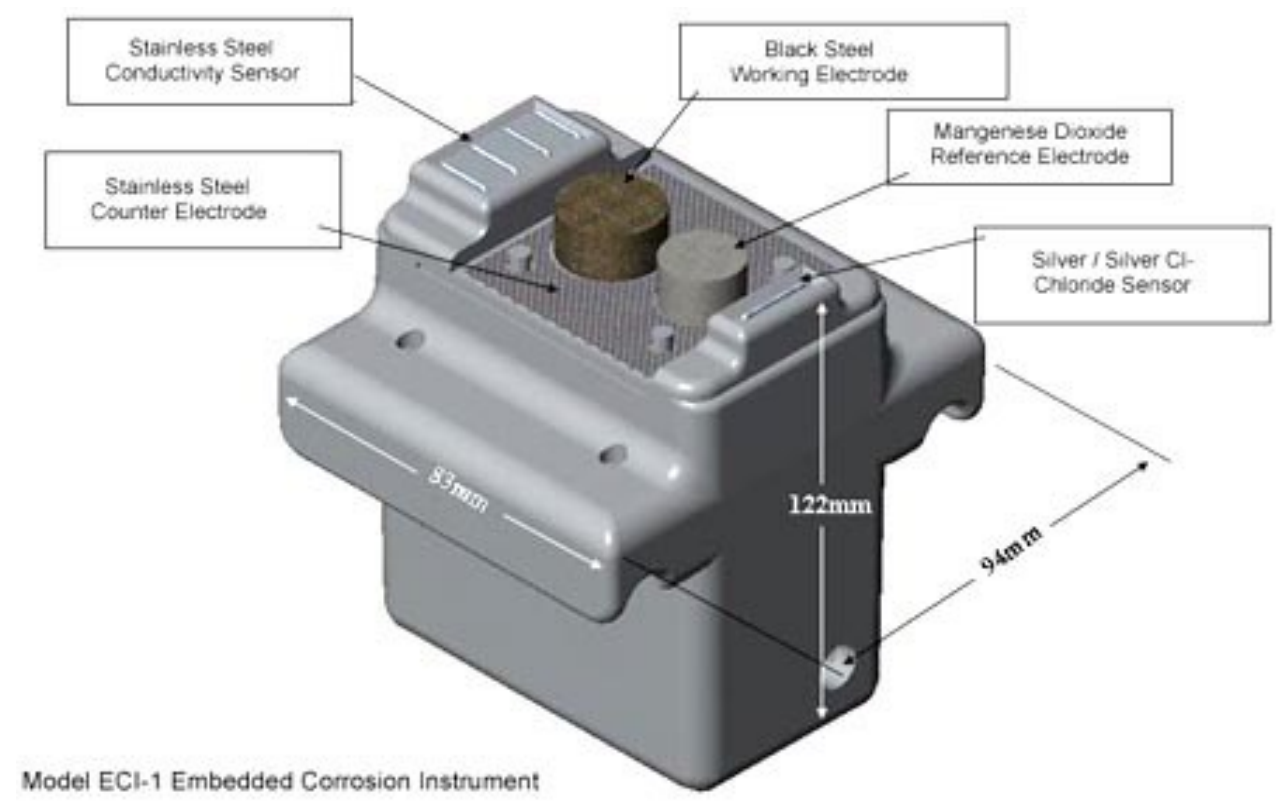

Figure 3-6 Embedded Corrosion Instrument, ECI, (VTI 2014) 


\subsubsection{Low-Cost, Passive Sensor for Corrosion Detection}

Results obtained by electrochemical corrosion monitoring methods are sensitive to environmental conditions such as temperature, chloride levels and moisture content of the surrounding concrete (Millard et al. 2001, Broomfield, 2007). A prototype passive sensor (Figure 3-7) that is not sensitive to variations in the surrounding environmental conditions has been developed to detect the initiation of corrosion in reinforced concrete. (Pasupathy et al. 2009, Abu Yosef et al. 2012a).

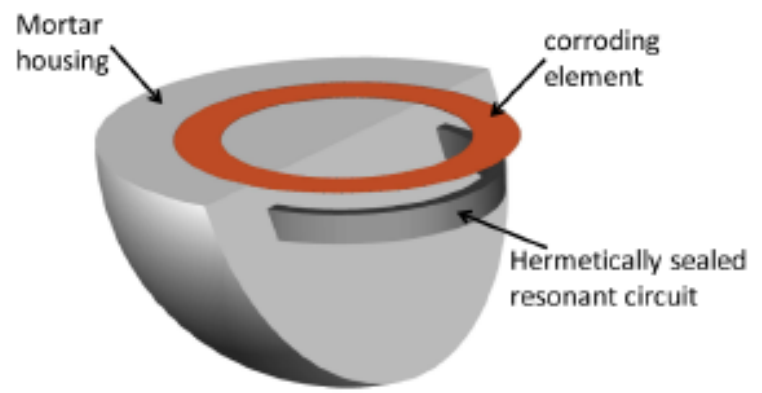

(a)

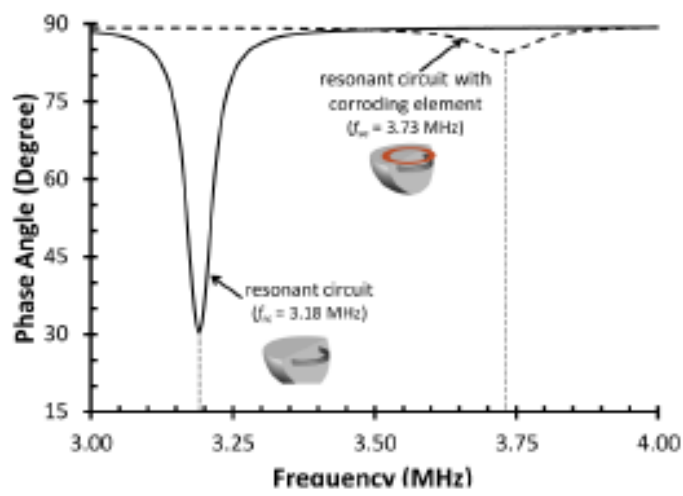

(b)

Figure 3-7 (a) Corrosion sensor configuration; (b) Change in phase response due to the presence of sacrificial element (Abu Yosef et al. 2012a)

In order to have a reliable reading, the sacrificial (corroding) element should have similar electrochemical properties as that of the reinforcing steel. As corrosion develops in the sacrificial element, resistance of the sensor increases, resulting in decrease in resonant frequency. The frequency eventually shifts back to that of the resonant circuit alone, indicating the threshold corrosion damage has been exceeded (Abu Yosef et al. 2012a).

The threshold corrosion damage can be specifically adjusted by changing the geometry of the sacrificial element or the distance between the sacrificial element and the resonant circuit (Abu Yosef et al. 2012b). Data from the sensors are collected by scanning with an external reader during bridge inspection. Figure 3-8 shows a schematic representation of the passive sensor platform. 


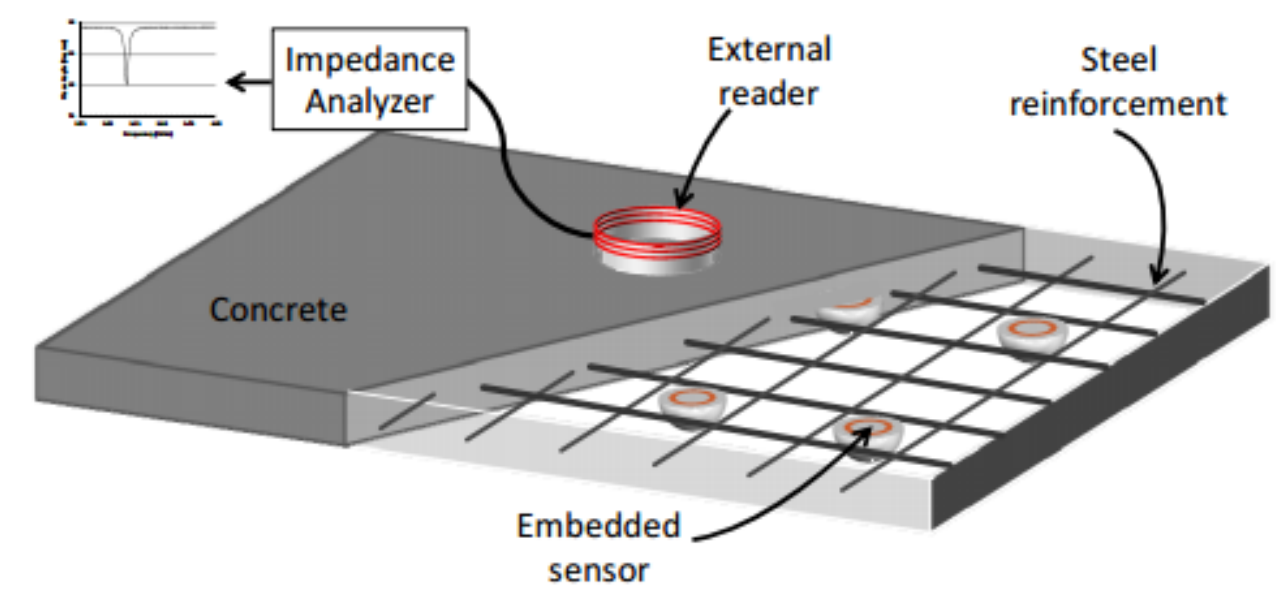

Figure 3-8 A schematic representation of the components of the passive sensor prototype (Abu Yosef et al. 2012b)

Though this sensor provides cost effective, wireless and battery-free alternative for corrosion monitoring (Abu Yosef et al. 2012a and 2012b), it still requires access to the structural member to conduct scanning operations.

\subsection{Ground Penetrating RAdar (GPR)}

Halabe et al. (2012) demonstrated the use of GPR technique in the laboratory to assess the condition of the embedded rebars in concrete. GPR equipment with $1.5 \mathrm{GHz}$ groundcoupled antenna was used to detect rebar corrosion in the laboratory specimen. Figure 3-9 shows the GPR scanning set up and concrete block with embedded rebars. Figure 3-10 shows the signal comparison between an uncorroded \#5 rebar with tight fit and a corroded \#5 rebar surrounded by moist sand (simulating deteriorated concrete). The corroded rebar shows a smaller signal amplitude compared to the uncorroded rebar. In the field, a comparison of the rebar reflections from one end of the bridge to the other can indicate areas with low rebar reflections which indicate potential corrosion. 


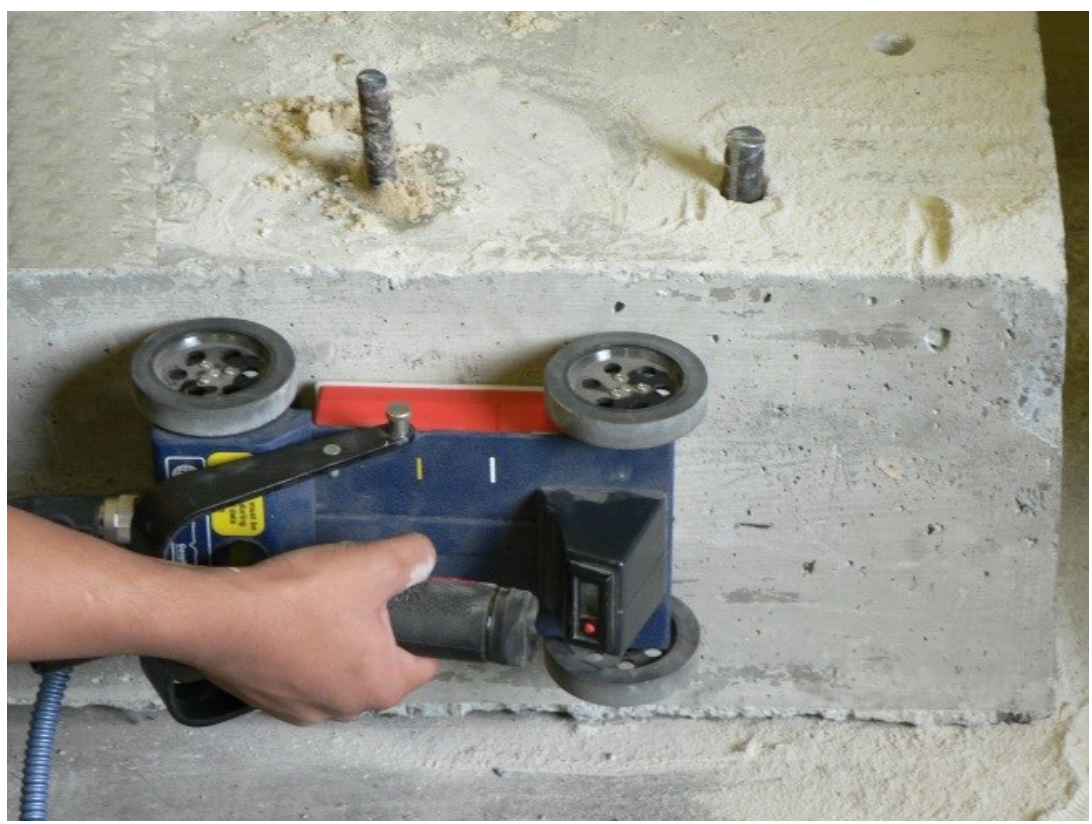

Figure 3-9 GPR scanning set up on the specimen with embedded rebars (Halabe et al. 2012)

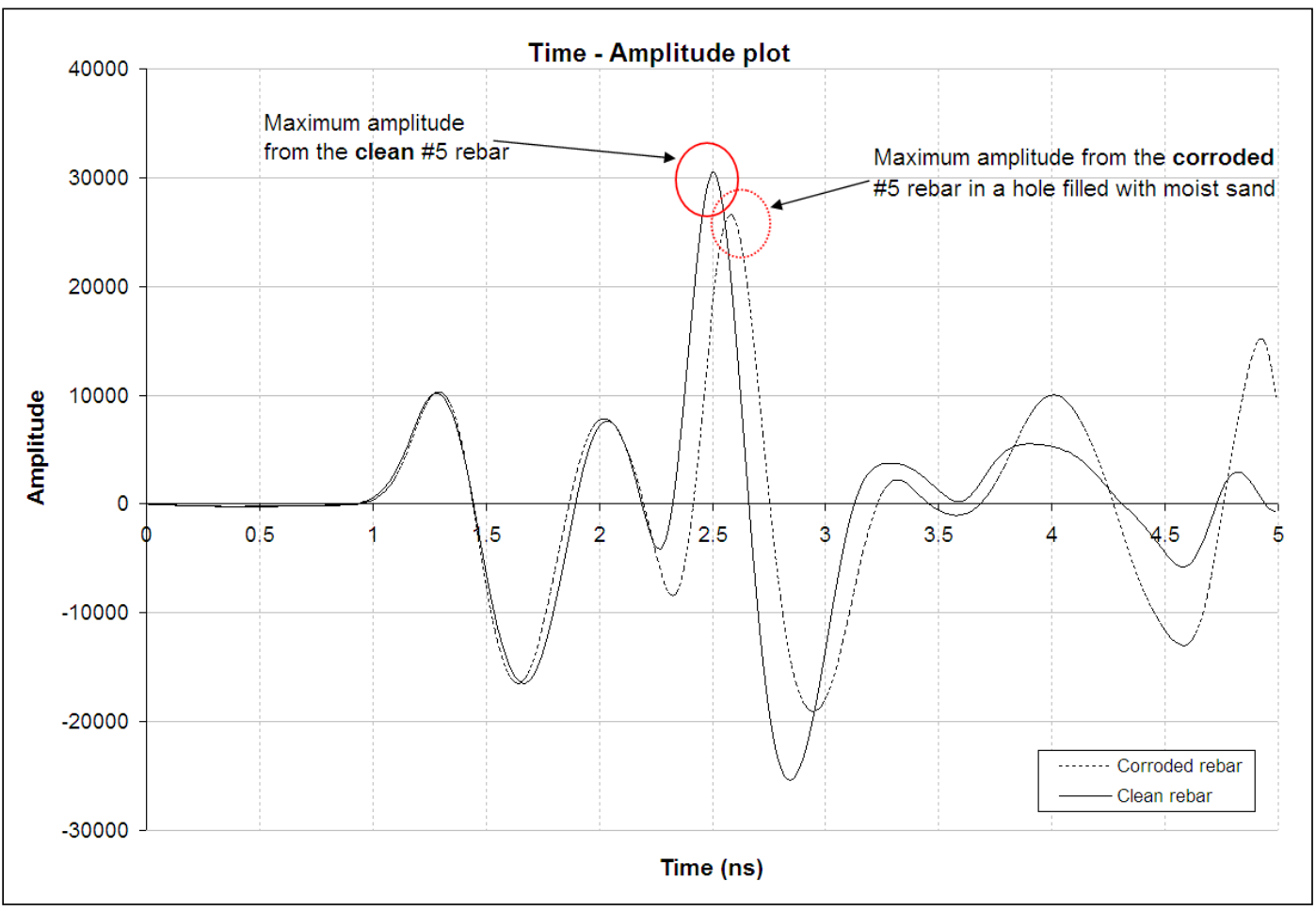

Figure 3-10 GPR signal comparison between clean (uncorroded) \#5 rebar and corroded \#5 rebar surrounded with moist sand (Halabe et al. 2012) 


\subsubsection{Limitations of Ground Penetrating Radar}

The GPR technique requires access to the reinforced concrete member being tested. This

often requires laborious and costly traffic control. The use of air-launched GPR antenna mounted on a vehicle can avoid the need for traffic control for bridge decks, but the data resolution is much lower compared to ground coupled antenna. For reinforced concrete members under the bridge (e.g., beams, pier caps, columns) use of ladders and traffic control is often needed. Also, the use of GPR is difficult for submerged and underground structural members.

\subsection{CONCLUSIONS}

The most commonly used corrosion monitoring techniques are summarized in this chapter, together with the associated limitations on each technique. In addition, these techniques (with the exception of the ECI) are not applicable in monitoring corrosion in structures encased in FRP jackets and/or structures with FRP wraps since the concrete surfaces of such structures are not available for scanning operations to be carried out. Structural members with glass fiber reinforced polymer (GFRP) jackets or wraps cannot be monitored with half-cell potential, concrete resistivity, and LPR methods since the above methods require electrical contact to the concrete surface for measurement to be taken. GFRP has a low electrical conductivity (an insulator) and therefore does not permit the needed electrical contact. Carbon fiber reinforced polymer (CFRP), on the other hand, has high electrical conductivity, allowing the applied current to flow through it to the concrete surface, provided an electrically conductive resin is used, which opens up the possibility of using the half-cell potential technique. However, the high electrical conductivity of CFRP jackets or wraps makes corrosion monitoring methods such as concrete resistivity, LPR, and the passive sensor discussed in this chapter inapplicable, since the current will flow on the surface instead of going through the concrete. Also, the high electrical conductivity of CFRP will prevent GPR signals from penetrating it.

Based on the findings of this chapter and the need for corrosion monitoring techniques that can be adapted to FRP jacket/wrapped structures, a low cost corrosion monitoring 
technique that makes use of embedded concrete resistivity sensor and temperature/humidity sensors is proposed in the following chapters. A comparison between the available corrosion monitoring techniques and the new sensor design presented in this study is shown in Table 3-9. The proposed sensors can be used for monitoring the potential for corrosion in reinforced concrete structures with or without CFRP/GFRP wraps. 
Table 3-4 Comparison between corrosion monitoring techniques

\begin{tabular}{|c|c|c|c|c|c|c|c|}
\hline \multirow[b]{2}{*}{ Suitability } & \multicolumn{7}{|c|}{ Corrosion Monitoring Technique/Sensor } \\
\hline & $\begin{array}{l}\text { Half-cell } \\
\text { potential }\end{array}$ & $\begin{array}{l}\text { Concrete } \\
\text { resistivity }\end{array}$ & $\begin{array}{l}\text { Linear } \\
\text { Polarization } \\
\text { Resistance }\end{array}$ & $\begin{array}{l}\text { Low-cost } \\
\text { passive } \\
\text { sensor }\end{array}$ & VTI ECI & $\begin{array}{l}\text { Ground } \\
\text { penetrating } \\
\text { radar }\end{array}$ & $\begin{array}{l}\text { Resistivity and } \\
\text { temperature/ } \\
\text { humidity }\end{array}$ \\
\hline $\begin{array}{l}\text { Does not require access to } \\
\text { structural member after } \\
\text { installation }\end{array}$ & No & No & No & No & Yes & No & Yes \\
\hline $\begin{array}{l}\text { Does not require access to the } \\
\text { embedded steel for monitoring }\end{array}$ & No & Yes & No & Yes & Yes & Yes & Yes \\
\hline $\begin{array}{l}\text { Can be used on } \\
\text { buried/submerged structures }\end{array}$ & No & No & No & No & N/A & Difficult & Yes \\
\hline $\begin{array}{l}\text { Can be used on GFRP } \\
\text { shell/wrapped structures }\end{array}$ & No & No & No & Possible & Yes & Yes & Yes \\
\hline $\begin{array}{l}\text { Can be used on CFRP } \\
\text { shell/wrapped structures }\end{array}$ & Possible & No & No & No & Yes & No & Yes \\
\hline $\begin{array}{l}\text { Can be used for remote } \\
\text { monitoring }\end{array}$ & No & No & No & No & Yes & No & Yes \\
\hline $\begin{array}{l}\text { Easy usage and data } \\
\text { interpretation }\end{array}$ & Yes & Yes & No & Yes & $\mathrm{N} / \mathrm{A}^{1}$ & No & Yes \\
\hline $\begin{array}{l}\text { Can measure the rate of } \\
\text { corrosion }\end{array}$ & No & No & Yes & $\mathrm{No}^{2}$ & Yes & No & No \\
\hline Low cost & No & No & No & Yes & No & No & Yes \\
\hline
\end{tabular}

\section{Legend:}

N/A: Information not available

Possible: May be possible but has not been done

\footnotetext{
${ }^{1}$ Also requires power supply, and structural analysis is recommended to determine impart on structural integrity (VTI 2015)
}

${ }^{2}$ Gives an indication if the corrosion threshold is exceeded (Abu Yosef et al. 2012a) 


\section{Chapter 4. Experimental Design Methodology}

\subsection{INTRODUCTION}

The experimental design process used in developing the electrical resistivity sensor for monitoring reinforced concrete members is presented in this chapter. Preliminary designs were done and evaluated in the laboratory to assess their reliability before the final design was selected. Summary tables and graphs are presented in the following sections and the complete data for the preliminary design stage is available in Appendix A.

\subsection{Design Methodology}

During the preliminary design stage, six (6) 3"x3"x3" (76.20x76.20x76.20mm) concrete cubes were cast in the laboratory. Samples 1 and 2 had 3"x3" (76.20x76.20mm) plain carbon steel (A36 steel) plates of thickness 0.115" (2.92mm), spaced at 2.77" (70.36mm) ( $3 "-2$ x plate thickness) placed at two opposite sides of the cubes in the mold. Electrical connection was provided to each steel plate by means of connecting wires to enable resistance measurements to be taken as shown in Figure 4-1. Samples 3 and 4 had similar designs as 1 and 2 but with stainless steel plates in place of the plain carbon (A36) steel plates. Samples 5 and 6 were produced with plain concrete, without steel plates and were used in moisture content calculations as presented in section 5.4.1 of Chapter 5.

The weight of each mold (together with the steel plates and connecting wires for molds 1 through 4) was taken before the cubes were cast. The cubes were produced using Sakrete Fast-setting concrete mix (Figure 4-2), with a 28 day strength of $31 \mathrm{MPa}(4500 \mathrm{psi})$. Aggregates in the mix were measured and found to have sizes between $9 \mathrm{~mm}$ and $14 \mathrm{~mm}$. Figure 4-3 shows models of the cubes. 


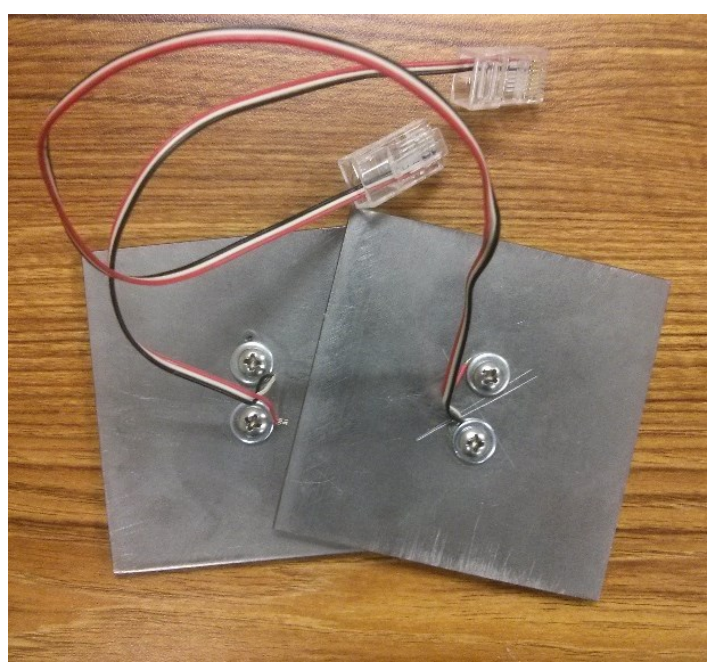

(a)

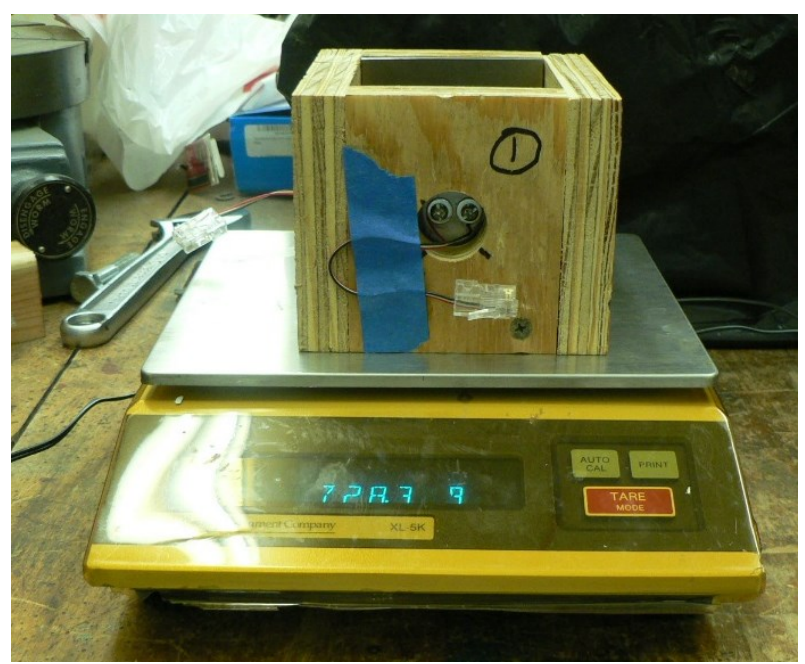

(b)

Figure 4-1 (a) Steel plates showing connecting wires, (b) Mold for sample 1 showing the steel plates with connecting wires

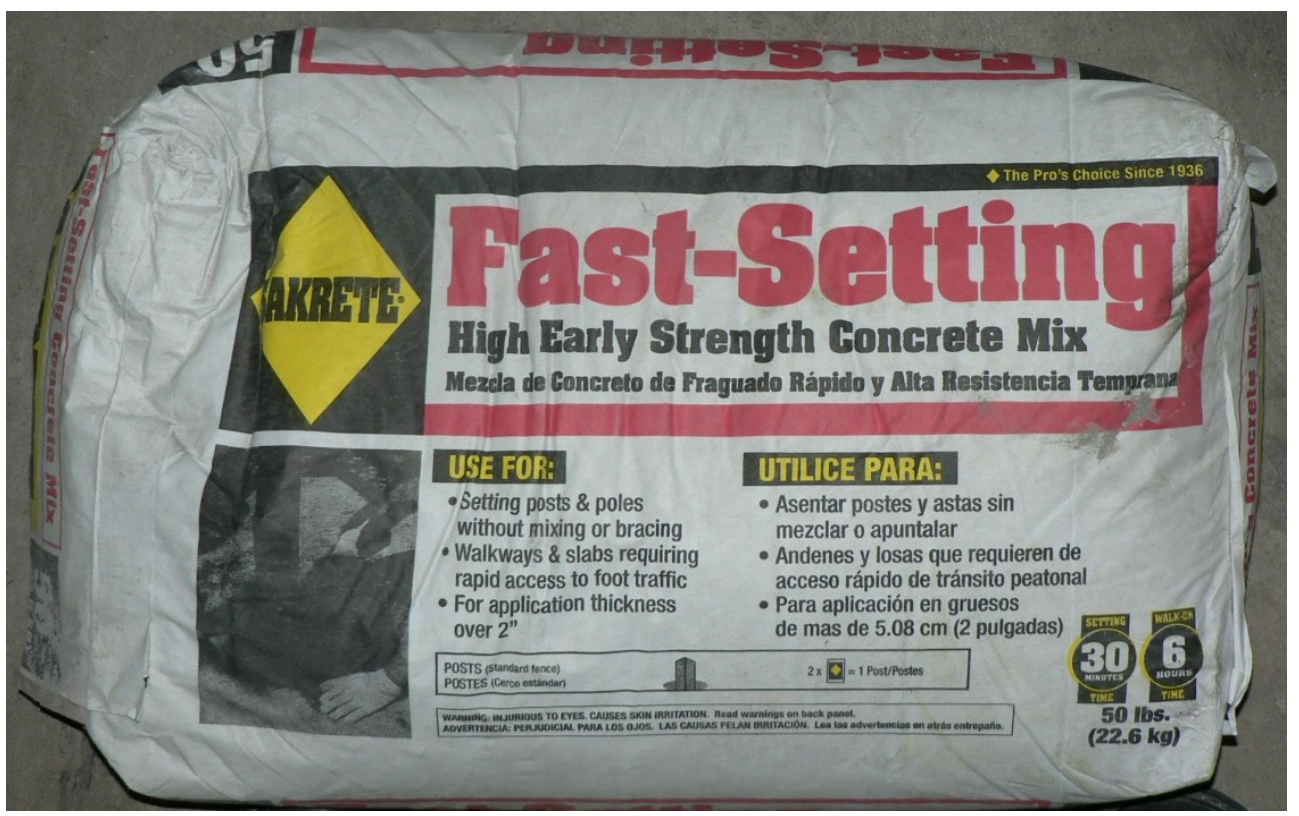

Figure 4-2 Sakrete concrete mix 


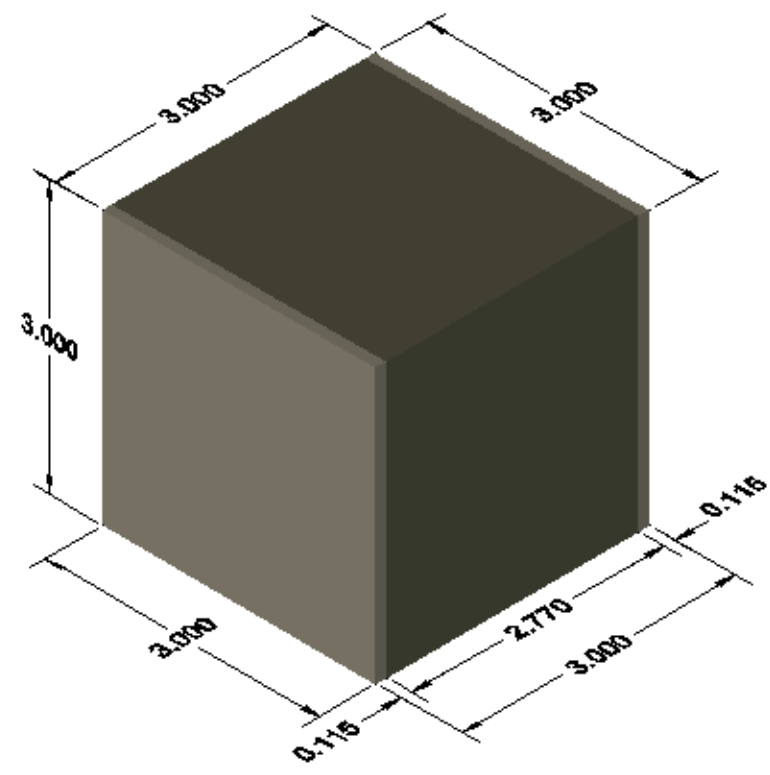

(a)

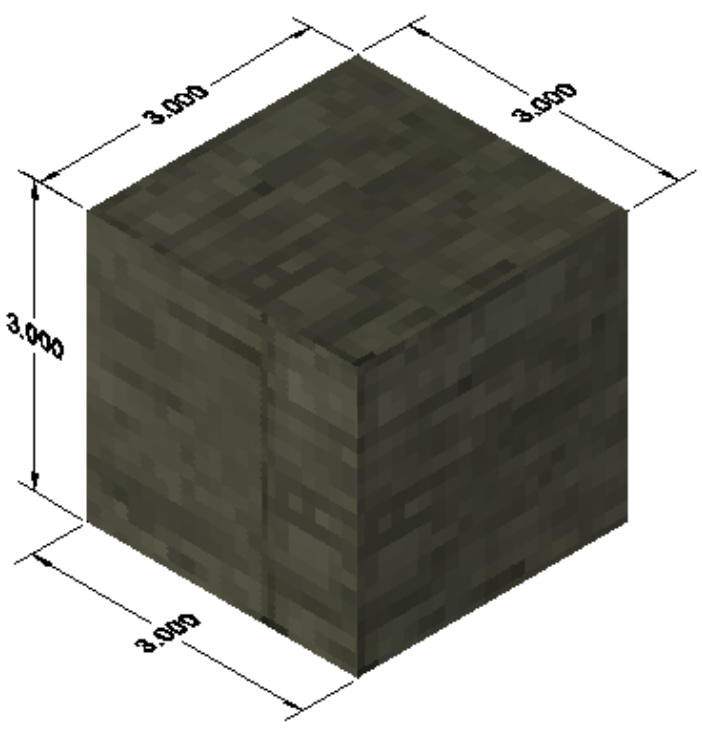

(b)

Figure 4-3 Models of (a) cubes with steel plates and (b) cube with no steel plates (dimensions in inches)

\subsubsection{Preliminary Data}

Weight and resistance data for the samples were taken three times on the day of casting and once a day on subsequent days while the concrete was curing as shown in Figure 4-4. The weighing balance had an accuracy of $0.1 \mathrm{~g}$. The resistance measurement unit (digital multimeter) had an accuracy of $0.001 \mathrm{k} \Omega$ for the $6 \mathrm{k} \Omega$ range, $0.01 \mathrm{k} \Omega$ for the $60 \mathrm{k} \Omega$ range, and $0.1 \mathrm{k} \Omega$ for the $600 \mathrm{k} \Omega$ range. The data collection process was continued until the concrete dried out. Table 4-1 summarizes the data obtaind from the pereliminary design.

The weight of each concrete cube was computed from the data in Table 4-1 by subtracting the weight of the mold and the steel plates, together with the connectors (connecting wires and end clips) from the total weight of the sample. Moisture content and electrical resistivity of the cubes at each data point was computed using the following equations.

$W=W_{\text {Total }}-\left(W_{\text {Mold }}+W_{\text {Plates \& connectors }}\right)$ 
Where;

$W=$ weight of concrete at each data point, $\mathrm{g}$

$W_{\text {Total }}=$ total weight of sample, $\mathrm{g}$

$W_{\text {Mold }}=$ weight of empty mold, $\mathrm{g}$

$W_{\text {Plates \& connectors }}=$ weight of two plates and wires/connector

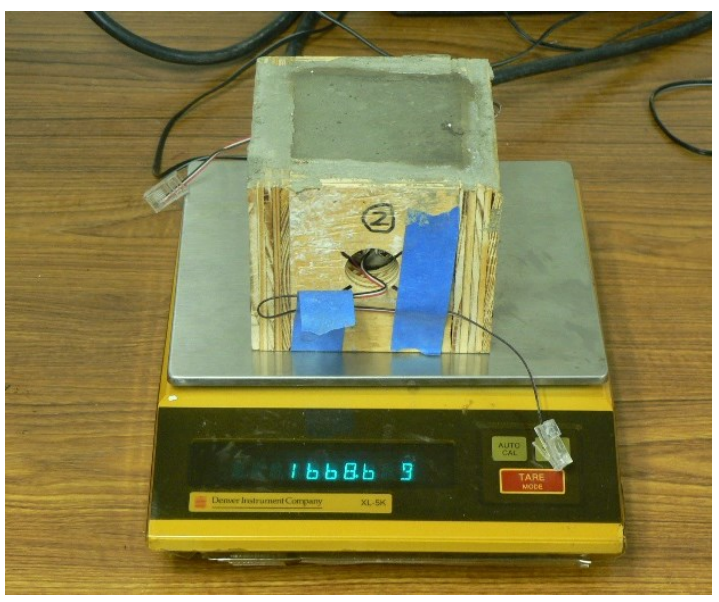

(a)

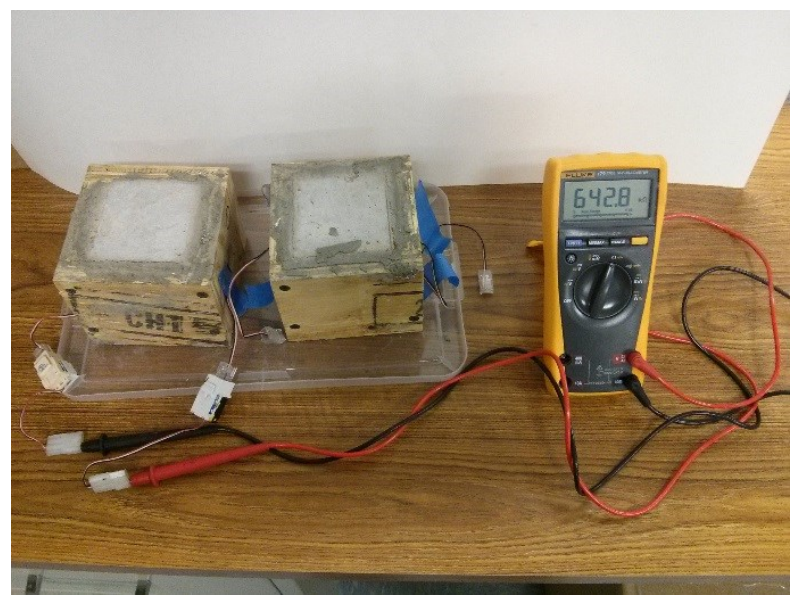

(b)

Figure 4-4 (a) Taking the weight of a sample (b) Resistance measurement of samples

Based on the moisture content equations available in Das (2010),

$W_{\text {Solids }}=\frac{W_{\text {Lab dry }}}{1+W_{\text {Lab dry }}}$

Where;

$W_{\text {Solids }}=$ weight of solids in the concrete cube (oven dry weight), $\mathrm{g}$

$W_{\text {Lab dry }}=$ weight of lab dry concrete, $\mathrm{g}$

$w_{L a b} d r y=$ moisture content of the concrete at lab dry condition

$W=W_{\text {solids }}(1+w)$

Where;

$W=$ weight of the concrete cube at each data point, $\mathrm{g}$

$W_{\text {Solids }}=$ weight of solids in the concrete cube (oven dry weight), $\mathrm{g}$ $w=$ the moisture content of the concrete at each data point 
Table 4-1 Weight and resistance data for preliminary samples

\begin{tabular}{|c|c|c|c|c|c|c|c|c|}
\hline \multirow[b]{2}{*}{$\begin{array}{c}\text { Time } \\
\text { (Days) }\end{array}$} & \multicolumn{2}{|c|}{$\begin{array}{c}\text { Sample \#1 } \\
\text { (plain carbon steel) }\end{array}$} & \multicolumn{2}{|c|}{$\begin{array}{c}\text { Sample \#2 } \\
\text { (plain carbon steel) }\end{array}$} & \multicolumn{2}{|c|}{$\begin{array}{c}\text { Sample \#3 } \\
\text { (stainless steel) }\end{array}$} & \multicolumn{2}{|c|}{$\begin{array}{c}\text { Sample \#4 } \\
\text { (stainless steel) }\end{array}$} \\
\hline & $\begin{array}{c}\text { Weight, } \\
\text { W }_{\text {Total }}(\mathrm{g})\end{array}$ & $\begin{array}{c}\text { Resistance, } \\
\text { R (k } \Omega)\end{array}$ & $\begin{array}{l}\text { Weight, } \\
\text { W }_{\text {Total }} \text { (g) }\end{array}$ & $\begin{array}{c}\text { Resistance, } \\
\text { R (k } \Omega \text { ) }\end{array}$ & $\begin{array}{c}\text { Weight, } \\
\text { W }_{\text {Total }} \text { (g) }\end{array}$ & $\begin{array}{c}\text { Resistance, } \\
\text { R (k } \Omega)\end{array}$ & $\begin{array}{l}\text { Weight, } \\
\text { W }_{\text {Total }}(\mathrm{g})\end{array}$ & $\begin{array}{c}\text { Resistance, } \\
\text { R (k } \Omega)\end{array}$ \\
\hline 0 & 1673.0 & 5.5 & 1678.8 & 2.1 & 1672.3 & 92.7 & 1685.7 & 27.0 \\
\hline 0 & 1673.0 & 13.6 & 1678.8 & 37.3 & 1672.3 & 95.7 & 1685.7 & 73.5 \\
\hline 0 & 1665.0 & 90.0 & 1670.3 & 23.0 & 1665.9 & 19.4 & 1676.7 & 17.1 \\
\hline 1 & 1662.0 & 70.4 & 1661.3 & 58.8 & 1658.7 & 60.8 & 1670.0 & 90.2 \\
\hline 2 & 1660.2 & 121.6 & 1662.3 & 98.9 & 1659.9 & 90.4 & 1673.1 & 147.7 \\
\hline 3 & 1661.9 & 251.8 & 1663.6 & 182.9 & 1661.8 & 193.0 & 1673.8 & 181.3 \\
\hline 7 & 1651.3 & 322.7 & 1655.5 & 366.6 & 1654.8 & 272.0 & 1665.1 & 307.5 \\
\hline 9 & 1646.2 & 396.5 & 1651.0 & 323.8 & 1650.1 & No Data & 1661.6 & No Data \\
\hline 10 & 1645.3 & 502.8 & 1650.2 & 382.5 & 1649.4 & 313.2 & 1660.9 & 381.6 \\
\hline 13 & 1642.8 & 608.4 & 1648.1 & 438.8 & 1647.4 & 386.0 & 1659.3 & 421.9 \\
\hline 14 & 1642.3 & 611.1 & 1648.4 & 434.4 & 1647.5 & 342.3 & 1659.3 & 394.0 \\
\hline 15 & 1642.2 & 605.8 & 1648.1 & 507.9 & 1647.4 & 409.5 & 1659.0 & 410.5 \\
\hline 16 & 1640.1 & 729.0 & 1646.0 & 601.8 & 1645.6 & 394.8 & 1657.6 & 478.0 \\
\hline 20 & 1636.0 & 758.0 & 1643.0 & 658.8 & 1642.6 & 414.6 & 1654.3 & 584.2 \\
\hline 21 & 1635.3 & 760.0 & 1642.1 & 641.4 & 1641.8 & 465.4 & 1653.5 & 592.2 \\
\hline 22 & 1635.1 & 771.0 & 1642.2 & 752.0 & 1641.8 & 483.3 & 1653.6 & 620.3 \\
\hline 23 & 1634.8 & 801.0 & 1642.6 & 828.0 & 1641.8 & 522.3 & 1653.6 & 773.0 \\
\hline 24 & 1634.5 & 818.0 & 1641.9 & 923.0 & 1641.5 & 606.0 & 1653.3 & 734.0 \\
\hline 35 & 1632.4 & 1005.0 & 1639.6 & 1209.0 & 1639.5 & 932.0 & 1651.1 & 1201.0 \\
\hline 38 & 1634.2 & 1231.0 & 1642.5 & 1689.0 & 1642.5 & 1053.0 & 1654.7 & 1170.0 \\
\hline 41 & 1631.1 & 1305.0 & 1639.5 & 1818.0 & 1639.4 & 1094.0 & 1651.6 & 1533.0 \\
\hline 44 & 1631.1 & 1387.0 & 1639.5 & 1613.0 & 1639.5 & 1224.0 & 1651.7 & 1348.0 \\
\hline 48 & 1632.4 & 1481.0 & 1641.2 & 1809.0 & 1641.2 & 1497.0 & 1653.6 & 1659.0 \\
\hline 50 & 1629.3 & 1548.0 & 1638.1 & 2305.0 & 1637.9 & 1814.0 & 1650.0 & 1699.0 \\
\hline 55 & 1627.4 & 1763.0 & 1636.6 & 2297.0 & 1636.5 & 1460.0 & 1648.7 & 1849.0 \\
\hline 57 & 1626.3 & 1887.0 & 1635.5 & 3041.0 & 1635.5 & 1525.0 & 1647.7 & 1768.0 \\
\hline 70 & 1628.1 & 2565.0 & 1637.6 & 4421.0 & 1637.6 & 2270.0 & 1649.8 & 2268.0 \\
\hline
\end{tabular}


Therefore,

$w=W\left(\frac{1+w_{\text {Lab dry }}}{W_{\text {Lab dry }}}\right)-1$

Extra weight data used for computing weight and moisture content are summarized in Table 4-2.

Table 4-2 Summary of extra weights and moisture content

\begin{tabular}{|l|r|l|}
\hline Weight of mold, $W_{\text {Mold }}$ & 508.1 & $\mathrm{~g}$ \\
\hline Weight of plates + connectors, $W_{\text {Plates \& } \& \text { connectors }}$ & 265.9 & $\mathrm{~g}$ \\
\hline Total extra weight, $\mathrm{g}$ & 774.0 & $\mathrm{~g}$ \\
\hline \multicolumn{2}{|l|}{} \\
\hline Lab dry moisture content, $w_{\text {Lab dry }}$ & 2.63 & $\%$ \\
\hline
\end{tabular}

Lab dry moisture content for the samples at 70 days after casting was found to be $2.63 \%$, which is an average of $2.66 \%$ for sample 5 and $2.60 \%$ for sample 6 . The procedure followed in computing these lab dry moisture contents, $w_{L a b} d r y$ is presented later in section 5.4.1 of Chapter 5. Electrical resistance of the plates and connecting wires was found to be $0.4 \Omega$. This is negligible compared to the measured concrete resistance (in $\mathrm{k} \Omega$ ) and hence not included in further computations.

From the data presented in Table 4-1, it was observed that the electrical resistance of the concrete cubes increased considerably from the initial values measured on the day of casting.

Electrical resistance of a material is a function of the electrical resistivity of the material and the ratio of the material length to its cross-sectional area as shown in Equation 4-5. Resistivity of the samples were computed from the resistance values using Equations 4-6 and 4-7, and summarized in Table 4-3.

$$
R=\rho \frac{L}{A}
$$


Where;

$R=$ electrical resistance of a uniform specimen of the material, $\mathrm{k} \Omega$

$\rho=$ electrical resistivity, $\mathrm{k} \Omega . \mathrm{m}$

$L=$ length of the material, $\mathrm{m}$

$A=$ cross-sectional area of the material, $\mathrm{m}^{2}$

Therefore;

$$
\rho=R\left(\frac{A}{L}\right)
$$

As discussed earlier in this chapter, 3" $\mathrm{x} 3$ " $(76.2 \times 76.2 \mathrm{~mm})$ steel plates with a spacing of 2.77" (70.36mm) were used.

Thus, for the concrete between the two steel plates,

$$
\frac{A}{L}=\frac{(3 \times 2.54)^{2}}{(2.77 \times 2.54)}=\frac{9 \times 2.54}{2.77} \approx 8.25 \mathrm{~cm}=0.0825 \mathrm{~m}
$$

Therefore;

$\rho=R \frac{A}{L}=0.0825 R(k \Omega . m)$

Electrical resistivity for each sample at various data points was computed and the various data are plotted as shown in Figures 4-5 through 4-8. 
Table 4-3 Moisture content and electrical resistivity of the preliminary samples

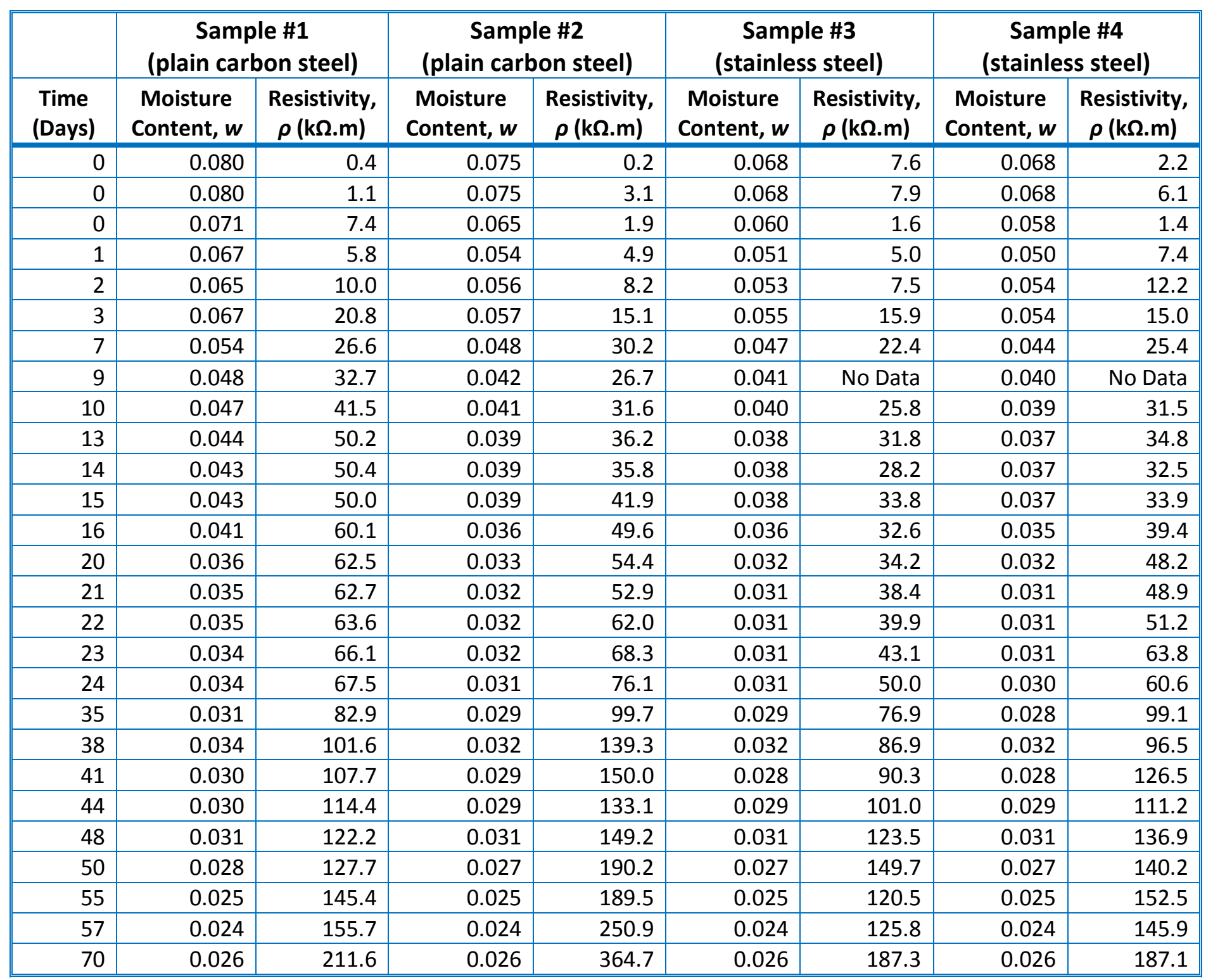




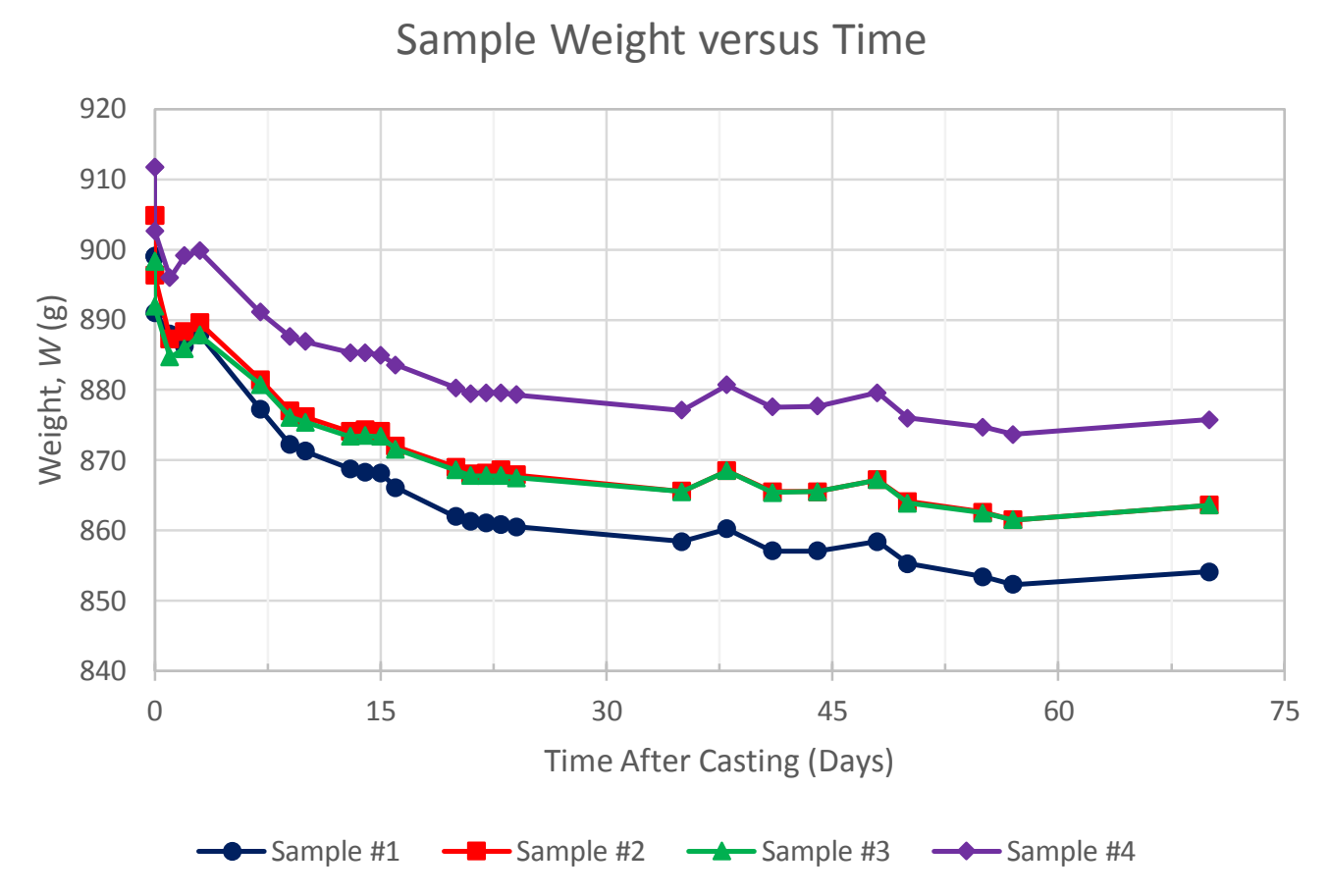

Figure 4-5 Variation of sample weight with time

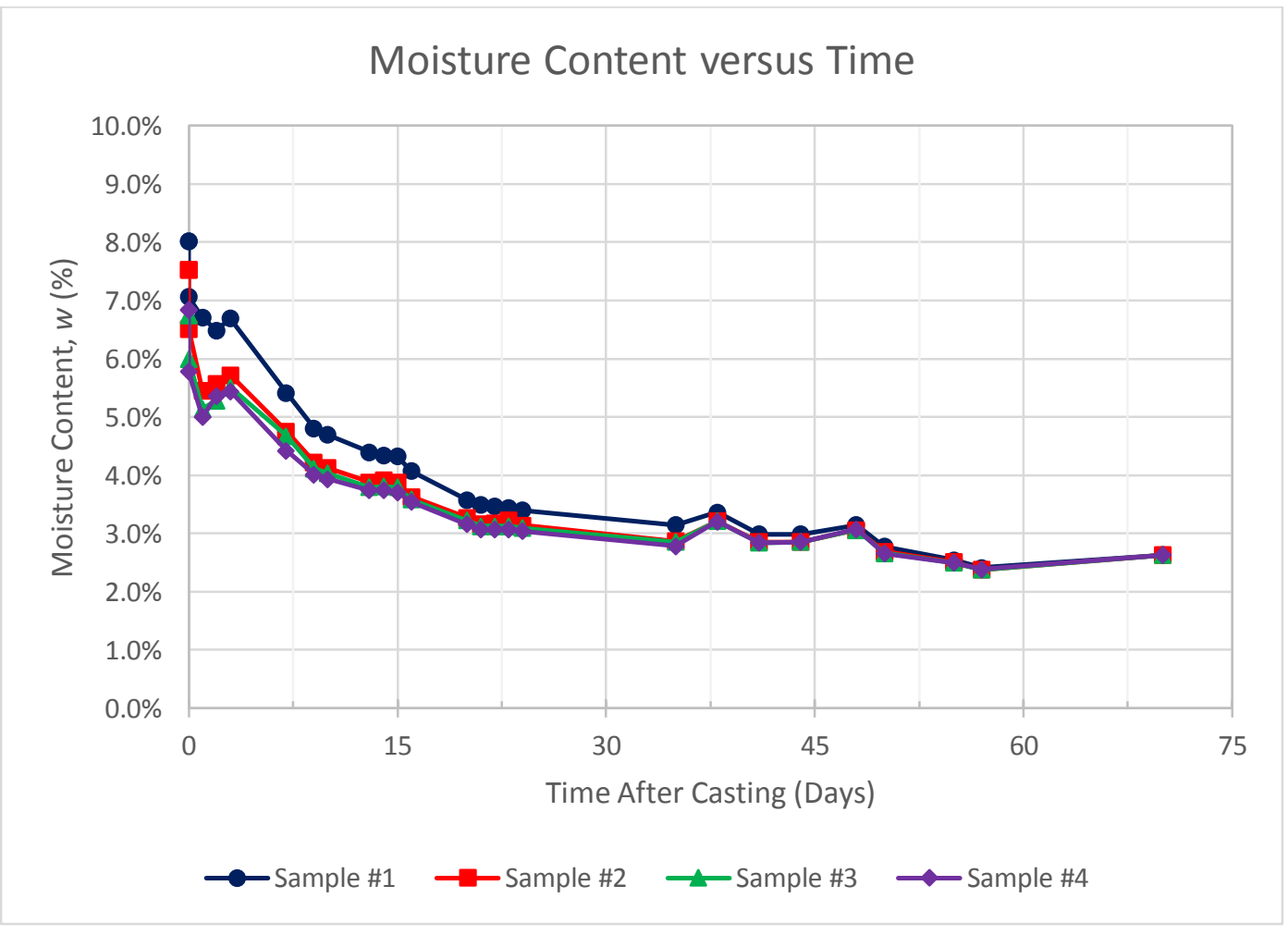

Figure 4-6 Variation of moisture content with time 


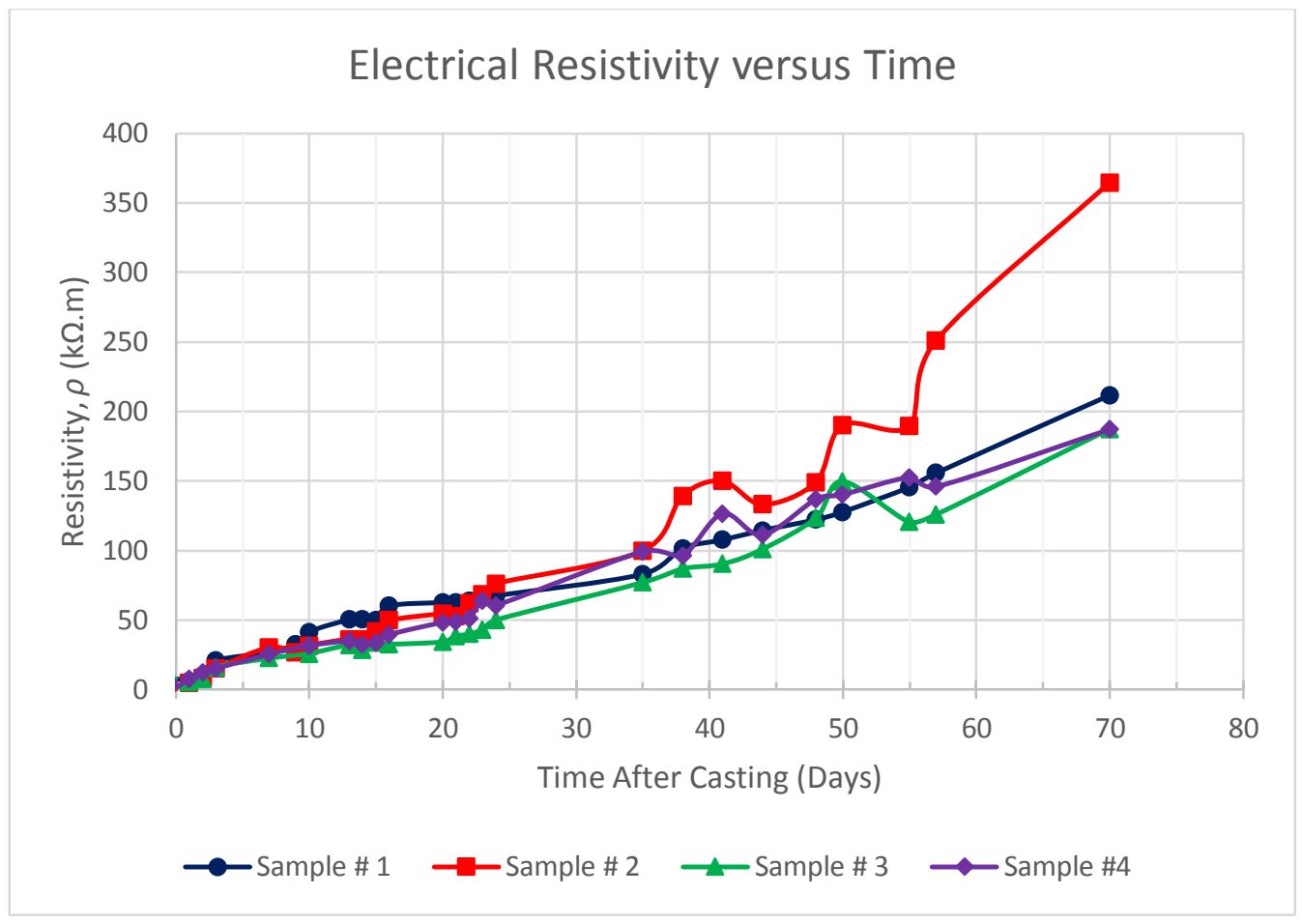

Figure 4-7 Variation of electrical resistivity with time

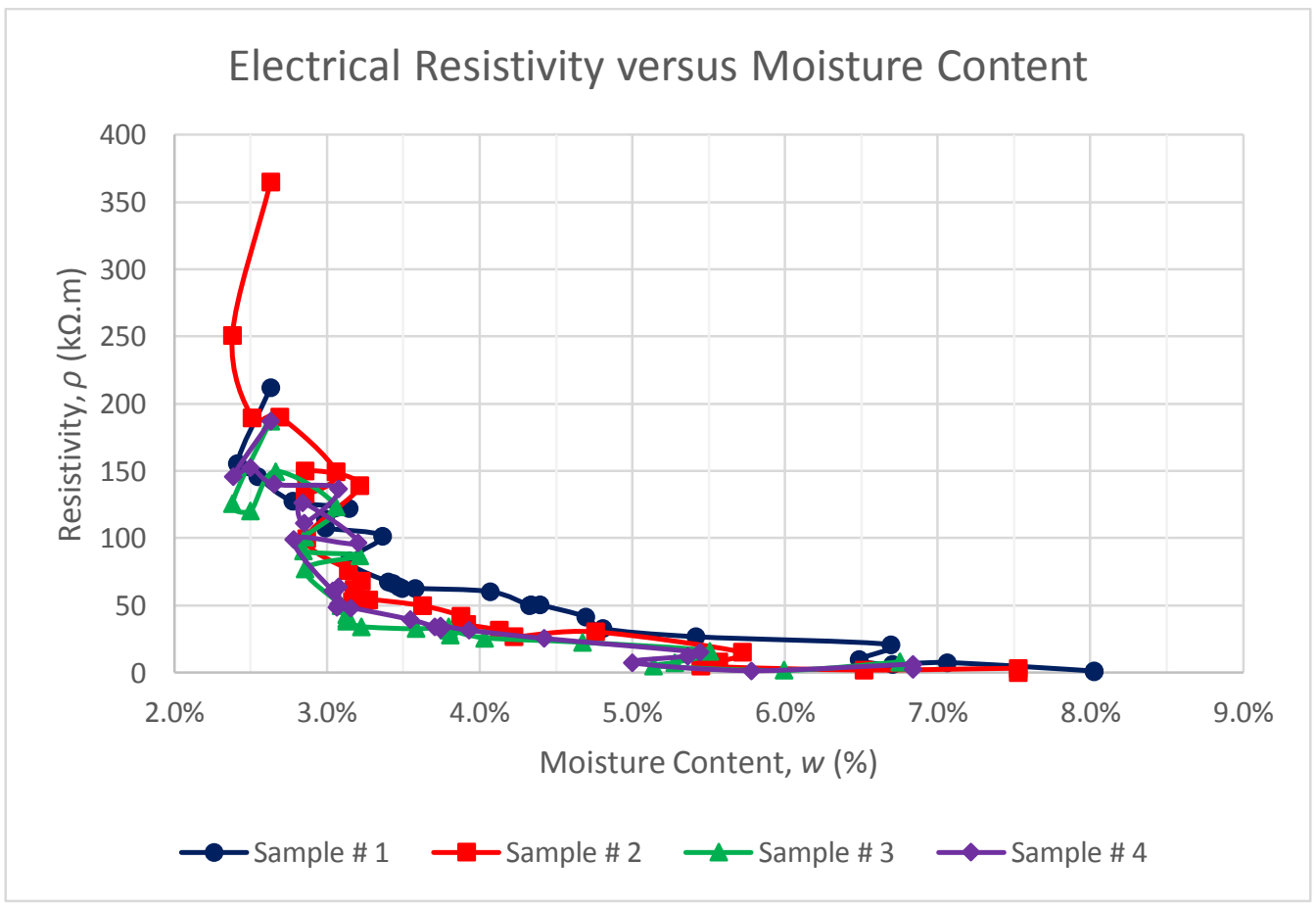

Figure 4-8 Variation of electrical resistivity with moisture content 
A scatter plot for resistivity verses moisture content for all four samples is shown below in Figure 4-9.

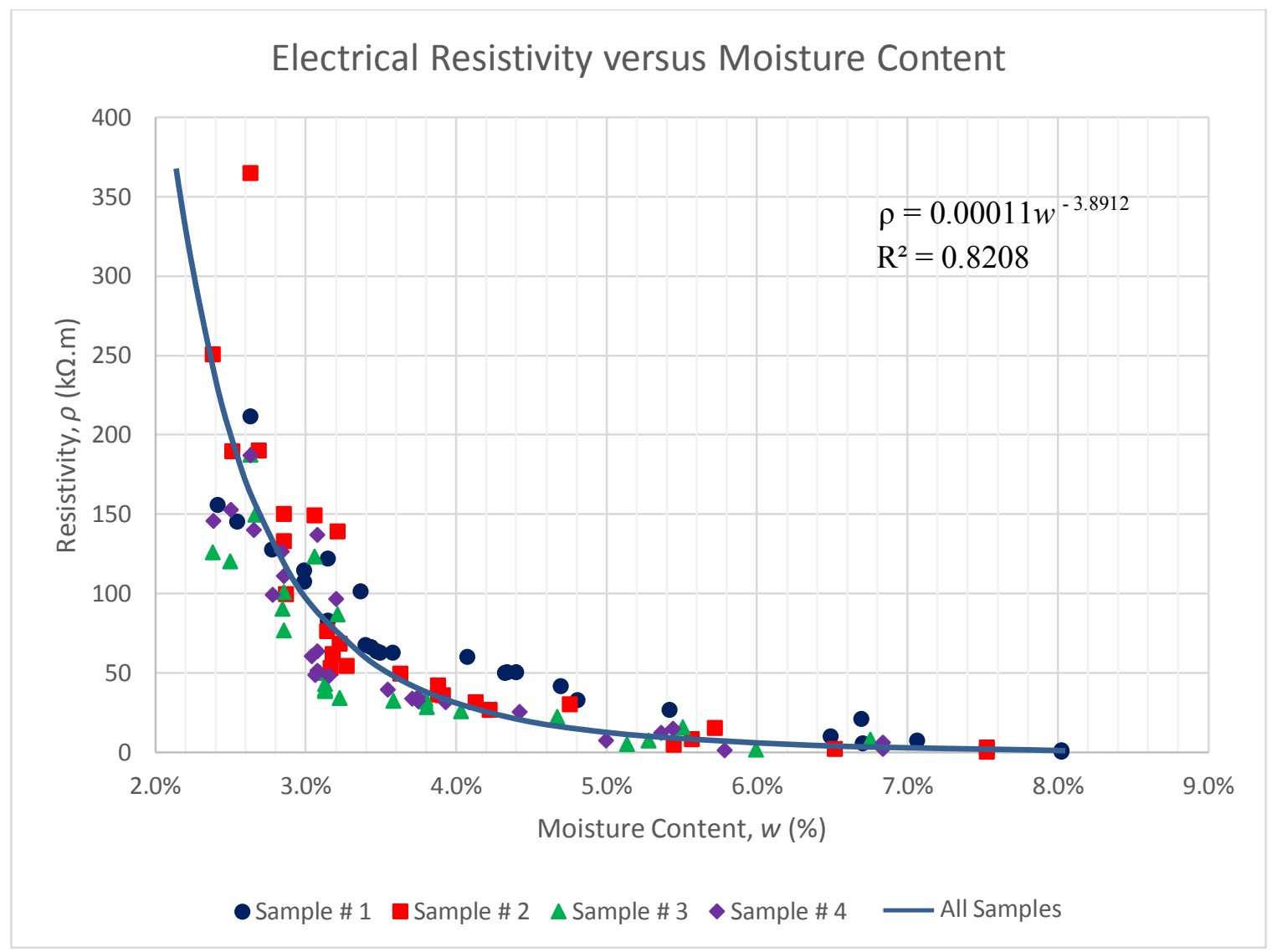

Figure 4-9 Variation of electrical resistivity with moisture content for all four samples

It is observed from the graphs in Figures 4-5 and 4-6 that both the sample weight and moisture content for all samples follow the same trend and decrease with time till equilibrium is achieved. It is further observed that samples 2, 3, and 4 have almost the same moisture content for all data points, with sample 1 having a slightly higher moisture content. Also, the moisture content graphs for all four samples (Figures 4-6) are much closer than the graphs for weights (Figures 4-5).

It is also observed from Figure 4-7 that the electrical resistivity of the samples remained within the same range of each other till the value reached over $200 \mathrm{k} \Omega . \mathrm{m}$. The resistivity 
values for samples 1,3 , and 4 remained close to $200 \mathrm{k} \Omega$.m but the value for sample 2 shot up to over $350 \mathrm{k} \Omega$.m. However, this should not be a problem since the remaining 3 samples continued to provide consistent values. In addition, data during field monitoring is not going to be collected beyond $200 \mathrm{k} \Omega$.m since such a high value will indicate dry concrete with very low likelihood of corrosion activity.

Similarly, resistivity verses moisture content plot in Figure 4-8 shows consistent data for all samples except when moisture content went below $2.63 \%$ and the value for sample 2 shot up outside the range of the other samples. Figure 4-9 also shows a trend line with exponential increase in resistivity values of the samples with decreasing moisture content. The equation for this trend line is given below.

Resistivity, $\rho=0.00011 w^{-3.8912}$

In the above equation, $\rho$ is in $\mathrm{k} \Omega$. $\mathrm{m}$ and $w$ is the actual value of the moisture content in decimals (not \%). The equation had a $\mathrm{R}^{2}$ value of 0.8208 as shown in Figure 4-9.

From the data in Tables 4-1 and 4-3 as well as Figures 4-5 through 4-9, it was observed that the resistance values of the cubes as measured in the lab was too high for field implementation purposes and there was a need to reduce these values to enable field measurements to be taken with ease. This was achieved by altering the geometry of the cubes as discussed below.

It can be observed from Equation 4-5 that for a constant cross-sectional area, the electrical resistance of the material decreases with a decrease in material length (L). Thus reducing the length of the specimen between the plates (i.e., reducing the plate spacing) will result in a lower electrical resistance, which is easier to measure in the field. The final design therefore has a reduced plate spacing to ensure lower resistance values as discussed in Chapter 5.

It can be seen from Figures 4-6 to 4-8 that the behavior of specimens with plain carbon steel (samples 1 and 2) is very similar to that of specimens with stainless steel (samples 3 
and 4). This is because the sensor measures the electrical resistance of concrete between the plates, and the electrical resistance of the plate itself is negligible compared to that of concrete. While stainless steel is a much more durable material which does not corrode during the life of the structural component, it is also much more expensive compared to plain carbon steel. Therefore, the sensors for field implementation were fabricated using the low-cost plain carbon steel as described in Chapter 5.

\subsection{Conclusions}

The preliminary design discussed in this chapter was done to determine the reliability of the chosen material and sensor geometry as well as to obtain data that aided in designing the final sensors for laboratory calibration and field implementation. Both the plain carbon steel and stainless steel specimens were found to produce good results. While stainless steel is a durable material which does not corrode, it is very expensive. Therefore, low-cost plain carbon steel was chosen for fabricating field sensors in the final design described in the next chapter. In addition, the spacing of the two plates was found to be too large, resulting in a high resistance value which is difficult to measure in the field. Hence, the plate spacing was reduced in the final design for field implementation. 


\section{ChaPter 5. CORROSION MONITORING IN REINFORCED CONCRETE MEMBERS}

\subsection{INTRODUCTION}

This chapter details the final design that was adopted for laboratory monitoring and field implementation after evaluating the preliminary design described in the previous chapter. Data obtained from the preliminary design and anticipated field conditions, as well as data collection technique and the measurement capacity of data collection device were critical for the final design of the sensors. Furthermore, laboratory investigation and data analysis to establish baseline values for field data interpretations are discussed in this chapter.

\subsection{Final Resistance SENSOR GeOMETRY}

As discussed in Chapter 4, the need to reduce the measured electrical resistance of the sensors resulted in reducing the spacing of the steel plates from the one used for the initial design. The spacing was therefore reduced from $2.77 "$ " $(70.36 \mathrm{~mm})$ to $1.50 "(38.10 \mathrm{~mm})$, resulting in about $46 \%$ anticipated reduction in the resistance value. This lower resistance value makes it easier for field measurements. The 1.50 " $(38.10 \mathrm{~mm})$ spacing is appropriate for the concrete mix consisting of coarse aggregates with size ranging from $9 \mathrm{~mm}$ to $14 \mathrm{~mm}$. The plate spacing of 2.5 times the maximum aggregate size ensures that the concrete within the plates is representative of the overall concrete without separation between coarse aggregate and the mortar mix.

To ensure the steel plates stay in place when the molds are removed, they were embedded in 4"x4"x4" $(101.60 \times 101.60 \times 101.60 \mathrm{~mm})$ concrete cubes. This resulted in 1.135" $(28.83 \mathrm{~mm})$ of concrete cover on both sides of the plate assembly and 0.50 " $(12.70 \mathrm{~mm})$ of concrete cover on the other four sides perpendicular to the plate thickness. The steel plates used has the same dimensions as the ones used in the preliminary design in Chapter 4, that is 3 "x3" $(76.20 \times 76.20 \mathrm{~mm})$ with $0.115 "(2.92 \mathrm{~mm})$ thickness. The geometry of the final 
design is shown in Figure 5-1. The sensors also had electrical wires connecting to the plates for resistance measurements as shown in Figure 5-2.

In the final design, plain carbon steel plates were used in producing the sensors because they were considerably cheaper than the stainless steel plates. In some of the corrosion monitoring techniques, it is better to use a material with similar electrochemical properties as the material used in constructing the structure to be monitored in manufacturing the sensors. This will ensure that the corrosive states of the sensors are directly related to that of the structural member being monitored. Since the sensor being developed here will not measure corrosion directly, and instead measure the resistance of concrete between the plates, the materials need not have similar electrochemical properties.

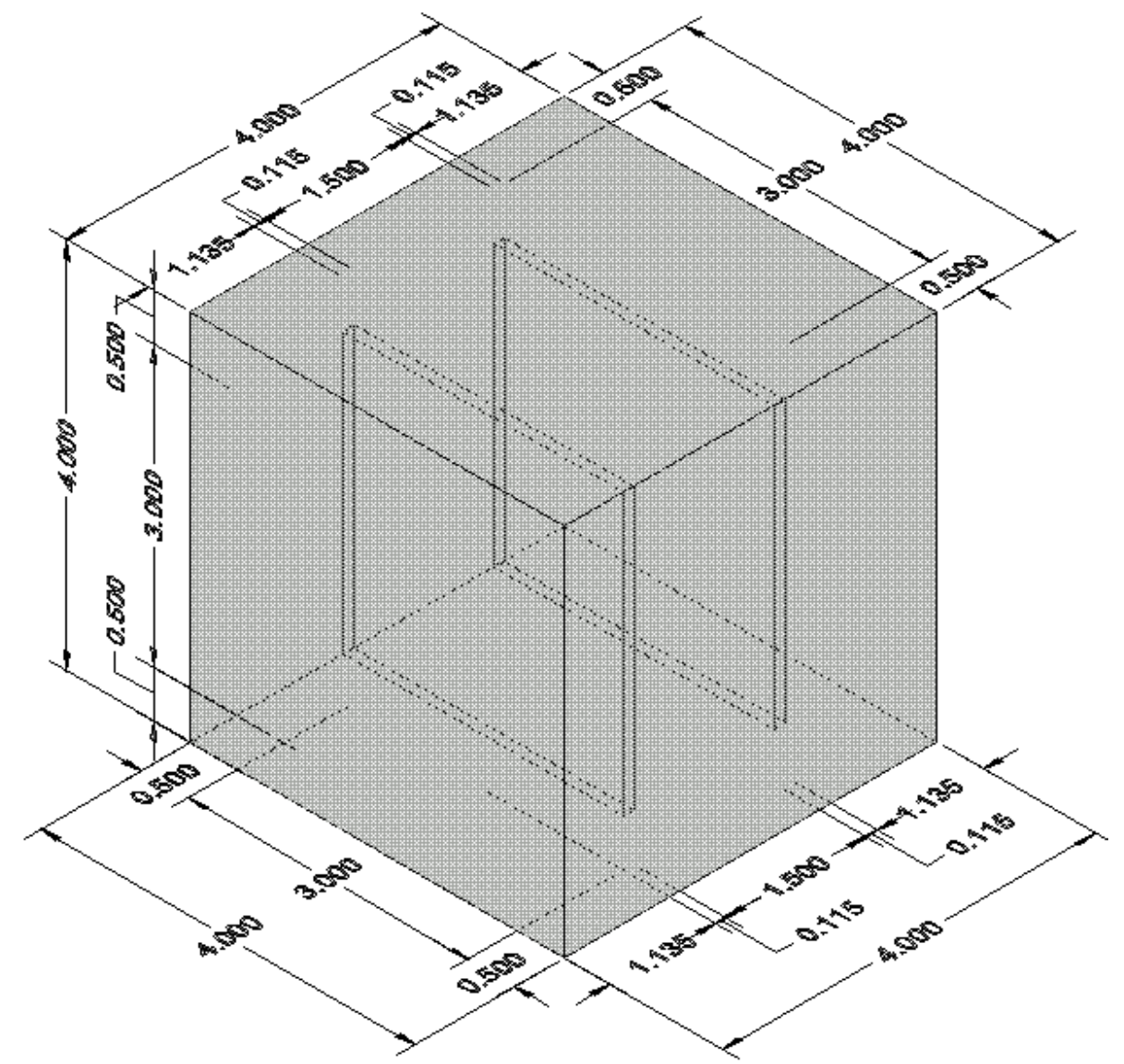

Figure 5-1 Final sensor geometry showing embedded steel plates (dimensions in inches) 
The sensors produced for field implementation and laboratory monitoring are shown in Figure 5-3 after they were removed from the molds.

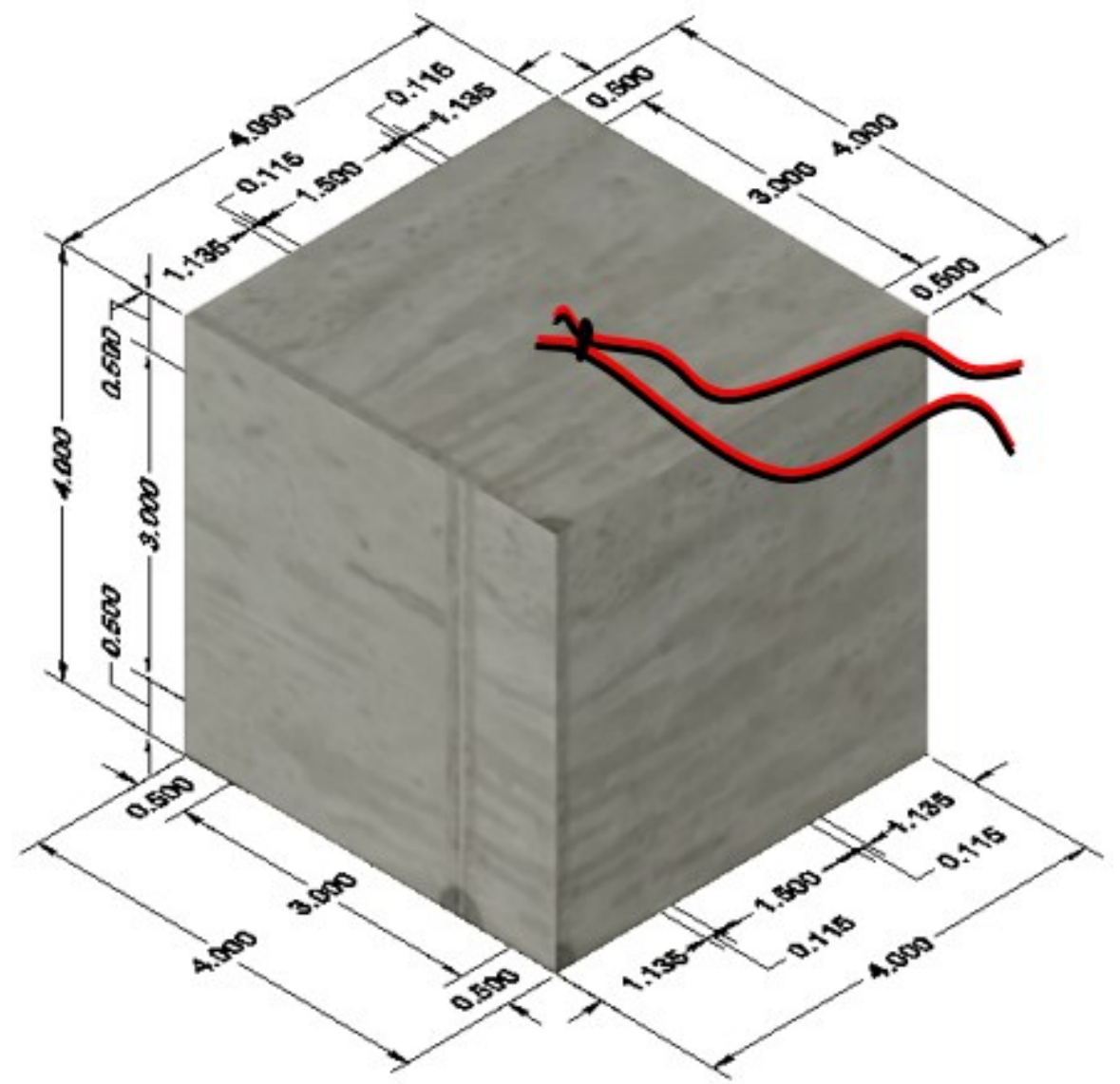

Figure 5-2 Model of the final electrical resistivity sensor (dimensions in inches)

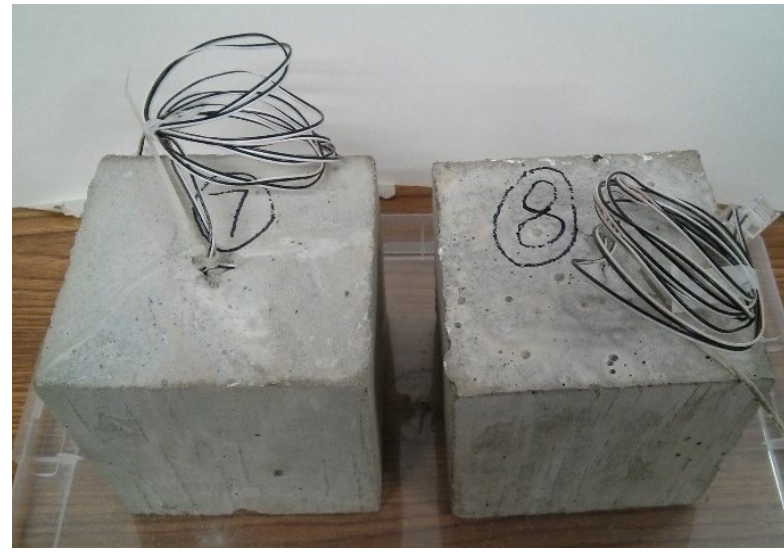

(a)

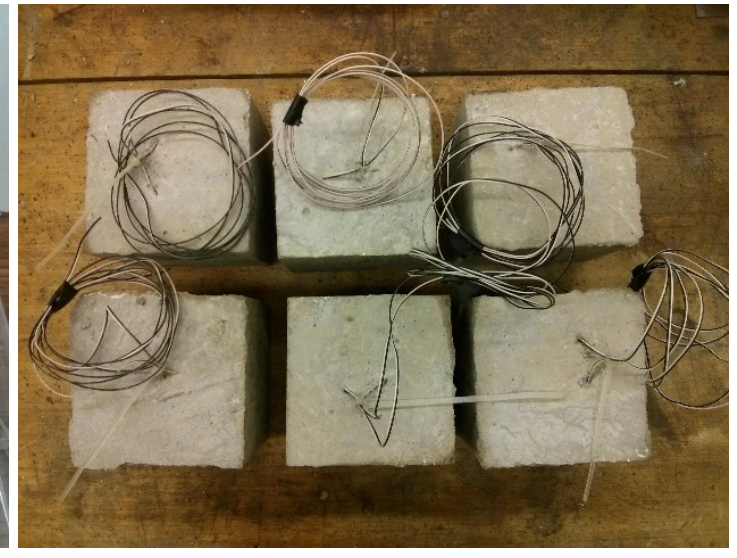

(b)

Figure 5-3 Actual sensors for (a) laboratory monitoring, (b) field implementation 


\subsection{TEMPERATURE /HUMIDITY SENSOR}

In addition to the resistance sensors, temperature/humidity sensors were also installed to monitor these factors (especially humidity) since they have direct effect on the concrete resistance and corrosion of steel encased in concrete. In addition, the humidity data will help determine whether lower resistance values observed are primarily due to higher moisture content of the concrete or due to corrosion activity. This will result in a better prediction of the potential for corrosion of encased steel.

The temperature/humidity sensor system was produced by installing commercially available sensor model, RB-Dfr-460, in a pre-cured 4"x4"x4" (101.60x101.60x101.60mm) concrete cube with 5/8" $(15.875 \mathrm{~mm})$ diameter and 3" $(76.20 \mathrm{~mm})$ deep hole at the top with $1 "(25.40 \mathrm{~mm})$ concrete at the bottom (Figure 5-4). The sensor and a model of the concrete cube are shown in Figure 5-5 and 5-6 respectively.

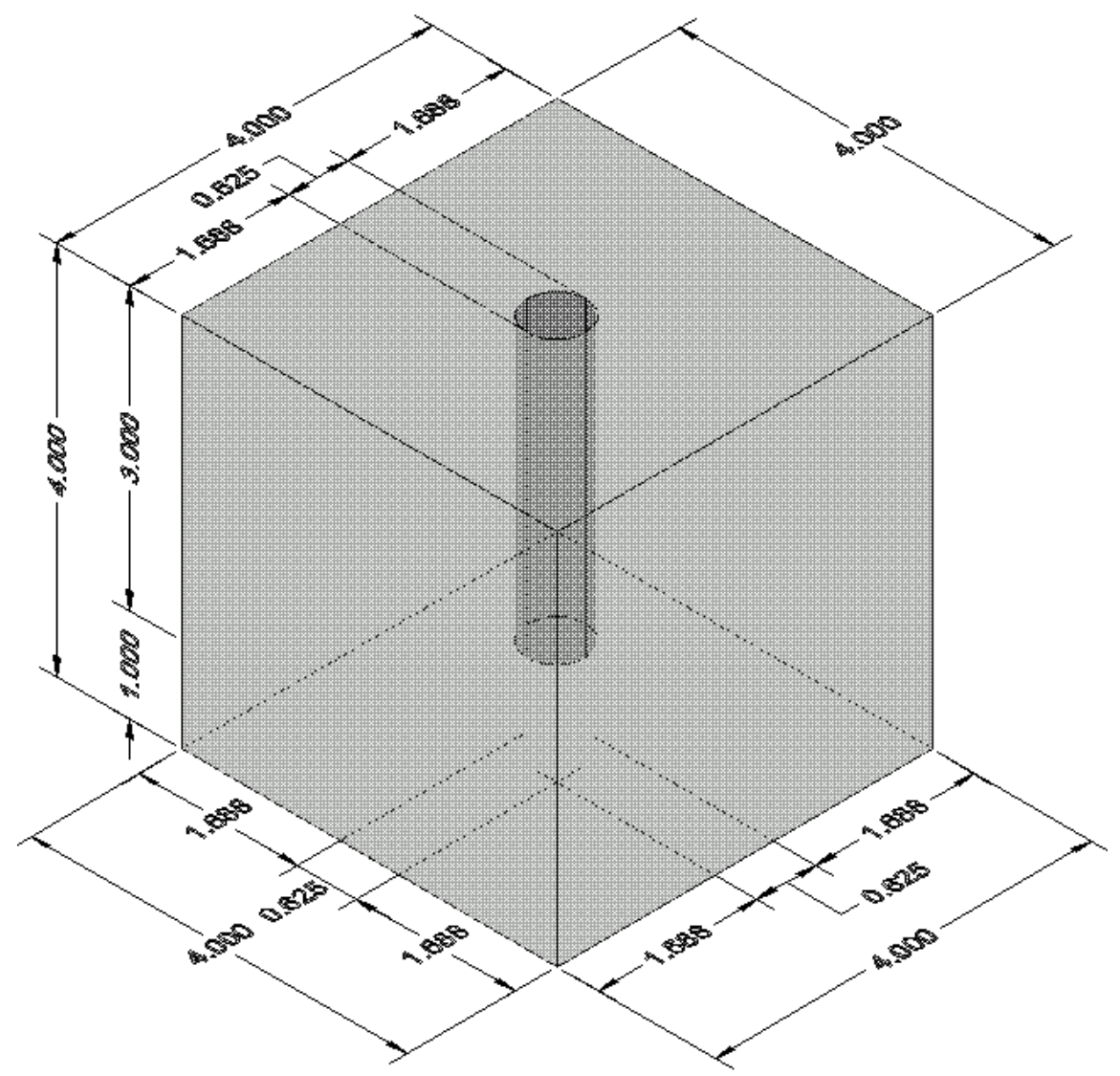

Figure 5-4 Geometry of cube for temperature/humidity sensor (dimensions in inches) 


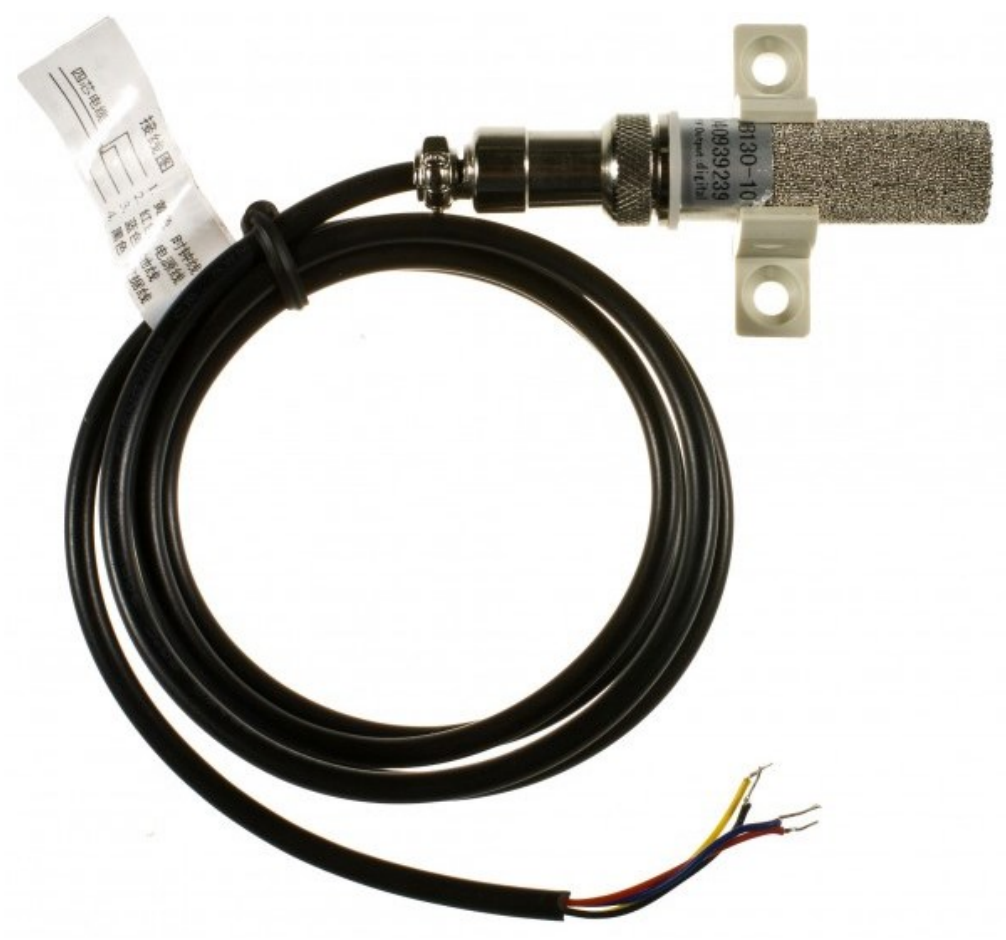

Figure 5-5 RB-Dfr-460 temperature/humidity sensor (RobotShop Inc. 2015)

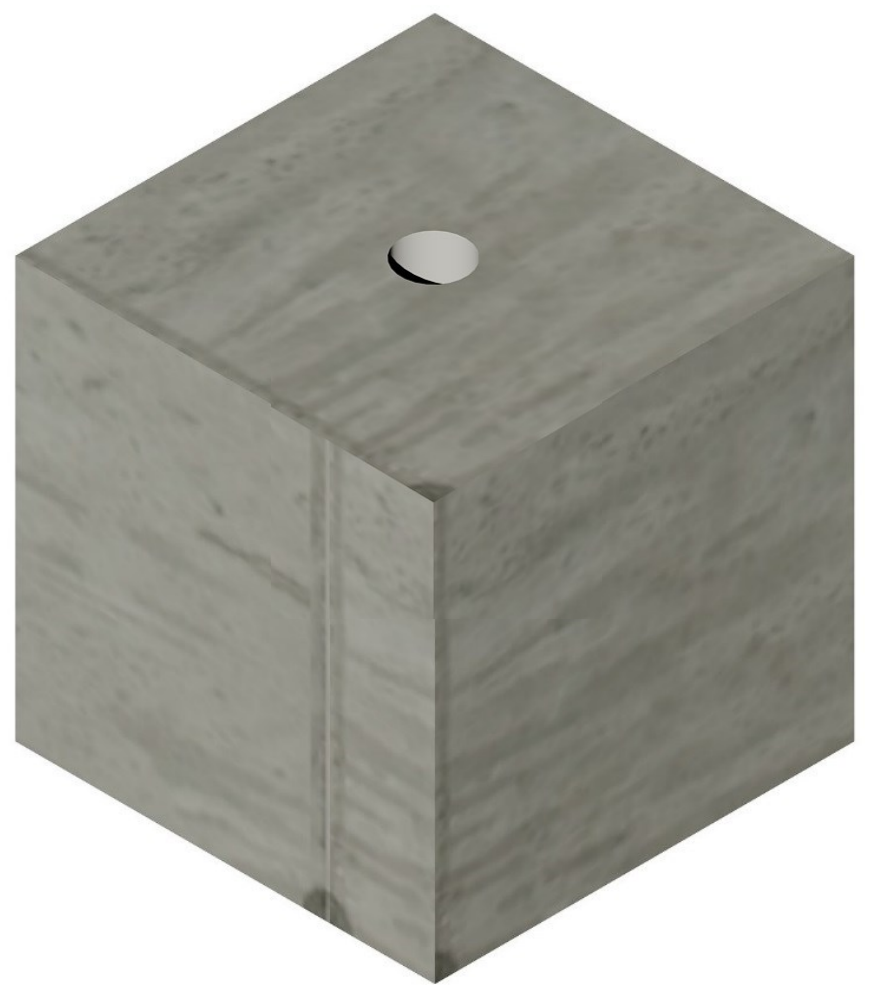

Figure 5-6 A model of the pre-cured concrete cube 
The sensors were installed in the cubes along with a plastic tube (on the top portion of the hole) to bring the wire out. The area around the wire (inside the plastic tube) was sealed up to prevent water and wet concrete from entering the hole through the opening. This ensures that moisture only gets to the sensors through the concrete pores and prevents the sensors from being damaged by wet concrete when installed in the field during construction or rehabilitation. Figure 5-7 shows the completed sensor assembly.

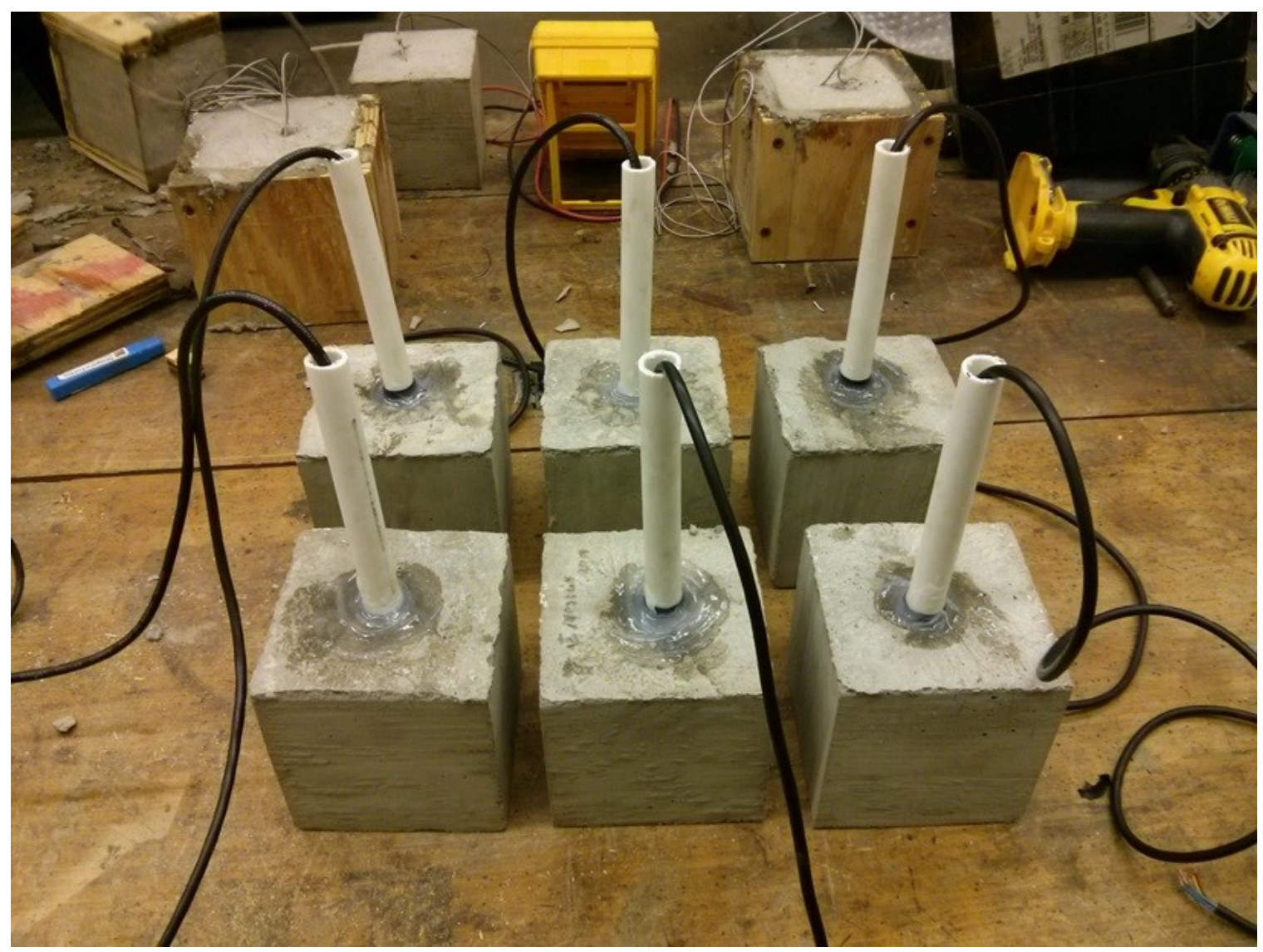

Figure 5-7 Final temperature/humidity sensor assembly

\subsection{Laboratory Calibrations}

Data was collected from two electrical resistivity sensors, R1 and R2, and one temperature/humidity sensor, T-H1, in the laboratory to develop calibration curves for data interpretation. Moisture content of the cubes is a critical component of this research as it is 
needed for the corrosion data interpretation in subsequent sections. Hence it is discussed next in this chapter.

\subsubsection{Moisture Content Computation}

As mentioned in Chapter 4, two concrete cubes (samples 5 and 6) of size 3"x3"x3" $(76.20 \times 76.20 \times 76.20 \mathrm{~mm})$ were cast without any embedded steel for the purpose of moisture content determination. Weight of samples 5 and 6 were monitored till it stabilized at 120 days from the day the cubes were cast. This data is presented in Table 5-1, together with the corresponding moisture content of the cubes.

Moisture content of the cubes were calculated using Equation 4-4 and lab dry moisture content of the cubes, which will be discussed later in this section. Figure 5-8 and 5-9 shows the variation of sample weight and moisture content with time respectively. The small increase in sample weight and moisture content towards the end of the curves in Figure 58 and 5-9 is attributed to an increase in laboratory atmospheric humidity. It is interesting to note that after the weight data was converted to moisture content, the curves for samples 5 and 6 completely overlap as shown in Figure 5-9. 
Table 5-1 Weight and moisture content for samples 5 and 6

\begin{tabular}{|c|c|c|c|c|}
\hline \multirow[b]{2}{*}{$\begin{array}{l}\text { Time } \\
\text { (Days) }\end{array}$} & \multicolumn{2}{|c|}{ Sample \#5 } & \multicolumn{2}{|c|}{ Sample \#6 } \\
\hline & $\begin{array}{l}\text { Weight, } W \\
\text { (g) }\end{array}$ & $\begin{array}{l}\text { Moisture } \\
\text { Content, } w\end{array}$ & $\begin{array}{l}\text { Weight, } w \\
\text { (g) }\end{array}$ & $\begin{array}{c}\text { Moisture } \\
\text { Content, w }\end{array}$ \\
\hline 0 & 999.9 & 0.077 & 1038.4 & 0.076 \\
\hline 0 & 999.9 & 0.077 & 1038.4 & 0.076 \\
\hline 0 & 992.1 & 0.068 & 1027.6 & 0.065 \\
\hline 1 & 984.4 & 0.060 & 1019.7 & 0.057 \\
\hline 2 & 987.6 & 0.063 & 1025.1 & 0.063 \\
\hline 3 & 989.1 & 0.065 & 1025.7 & 0.063 \\
\hline 7 & 979.2 & 0.054 & 1014.6 & 0.052 \\
\hline 9 & 974.2 & 0.049 & 1009.0 & 0.046 \\
\hline 10 & 973.0 & 0.048 & 1008.6 & 0.045 \\
\hline 13 & 970.0 & 0.044 & 1005.5 & 0.042 \\
\hline 14 & 969.4 & 0.044 & 1005.2 & 0.042 \\
\hline 15 & 968.9 & 0.043 & 1004.7 & 0.041 \\
\hline 16 & 966.8 & 0.041 & 1002.8 & 0.039 \\
\hline 20 & 962.4 & 0.036 & 998.4 & 0.035 \\
\hline 21 & 961.5 & 0.035 & 997.6 & 0.034 \\
\hline 22 & 961.2 & 0.035 & 997.3 & 0.034 \\
\hline 23 & 961.0 & 0.035 & 997.2 & 0.034 \\
\hline 24 & 960.5 & 0.034 & 996.7 & 0.033 \\
\hline 35 & 956.7 & 0.030 & 993.3 & 0.030 \\
\hline 38 & 959.2 & 0.033 & 995.9 & 0.032 \\
\hline 41 & 956.5 & 0.030 & 993.0 & 0.029 \\
\hline 44 & 956.4 & 0.030 & 992.9 & 0.029 \\
\hline 48 & 957.8 & 0.031 & 994.3 & 0.031 \\
\hline 50 & 954.6 & 0.028 & 991.1 & 0.027 \\
\hline 55 & 953.0 & 0.026 & 989.3 & 0.025 \\
\hline 57 & 951.8 & 0.025 & 988.3 & 0.024 \\
\hline 70 & 953.5 & 0.027 & 989.9 & 0.026 \\
\hline 79 & 960.0 & 0.034 & 995.8 & 0.032 \\
\hline 120 & 960.0 & 0.034 & 996.1 & 0.032 \\
\hline
\end{tabular}




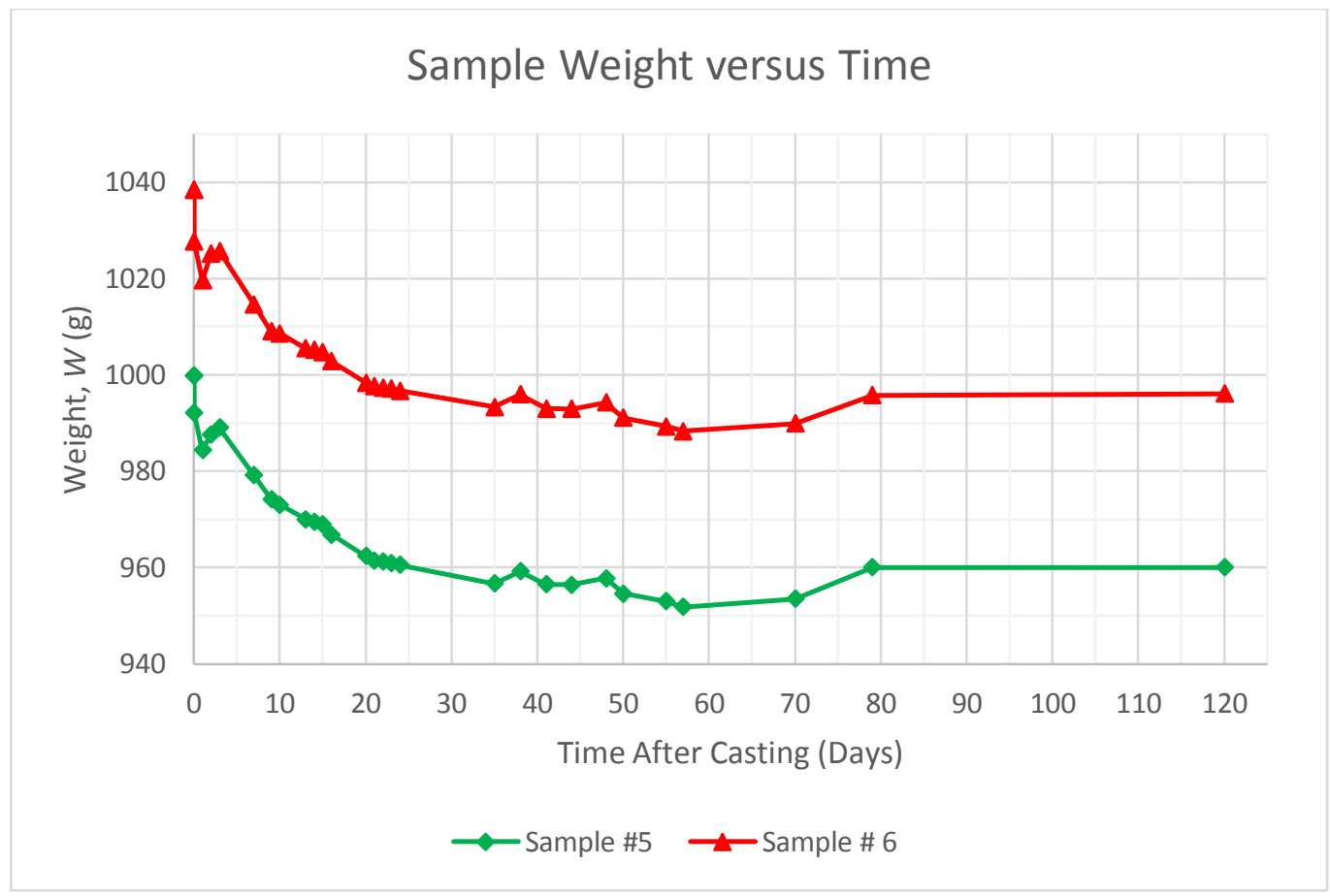

Figure 5-8 Variation of weight with time for samples 5 and 6

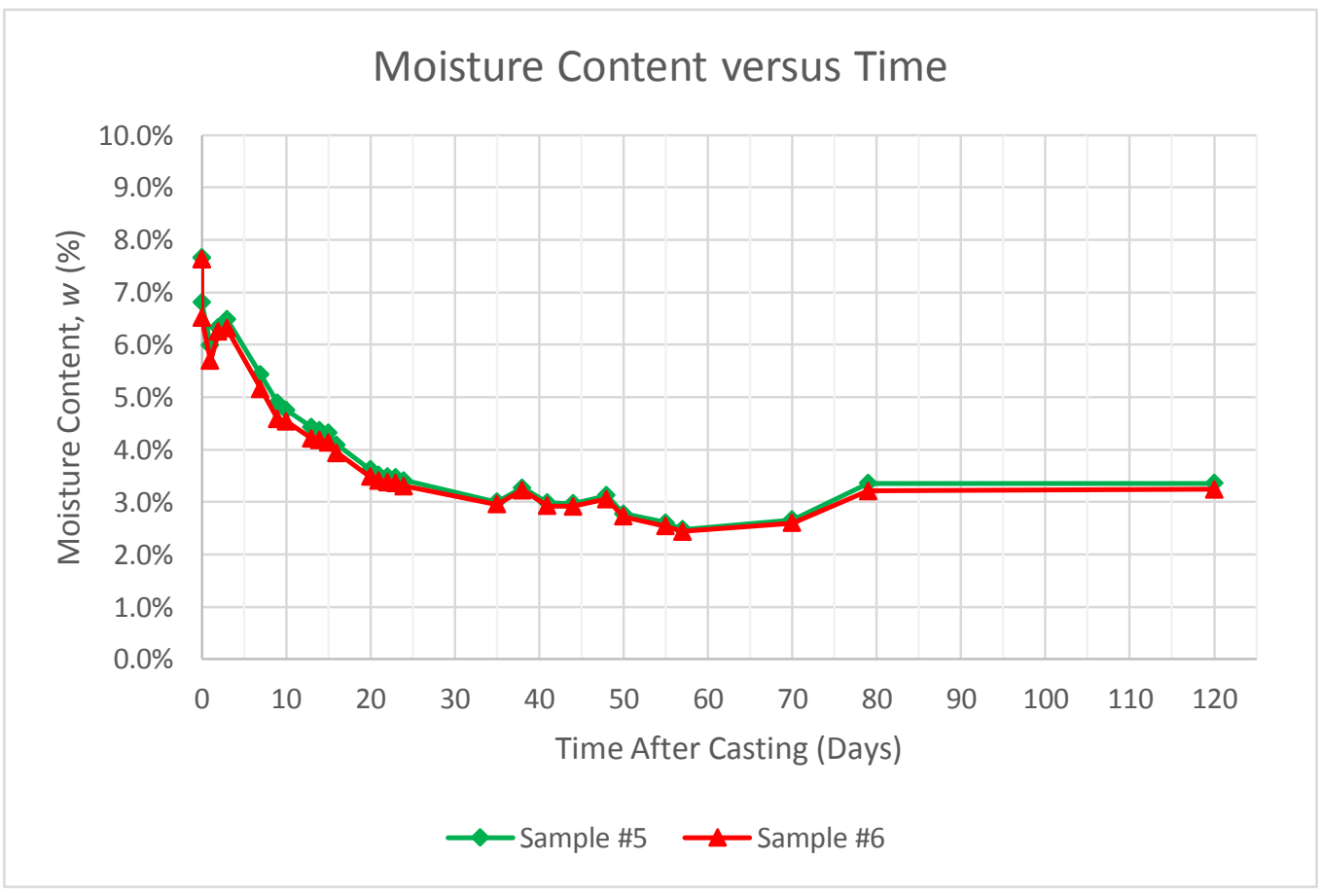

Figure 5-9 Variation of moisture content with time 
The weights of the two concrete cubes (samples 5 and 6) were allowed to stabilize in the laboratory over a period of 120 days after casting. Then these cubes were dried in the oven at a temperature of $110^{\circ} \mathrm{C}$ for 75 days. This was done to determine the weight of dry concrete (oven dry weight) for moisture content computations. Weight of the cubes were recorded in 15 day intervals and presented in Table 5-2. Moisture content was computed using Equation 5-1 after the drying process was completed.

Moisture Content $\left(w_{\text {Lab dry }}\right)=\frac{\text { Weight of water }\left(W_{\text {Water }}\right)}{\text { Weight of solids }\left(W_{\text {Solids }}\right)}$

Therefore;

$\begin{aligned} \text { Moisture Content }\left(w_{\text {Lab dry }}\right) & =\frac{\text { Labdry weight }- \text { Oven dry weight }}{\text { Oven dry weight }} \\ & =\frac{\text { Weight at day } 0-\text { Weight at day } 75}{\text { Weight at day } 75}\end{aligned}$

Moisture contents of $3.36 \%$ and $3.24 \%$ were obtained for sample 5 and 6 respectively. Average moisture content of the two samples was found to be $3.30 \%$, and this value will be used later to compute the moisture contents of samples R1, R2 and T-H1. It was also observed that, greater percentage of moisture in the cubes was lost during the first 15 days of oven drying. As shown in Table 5-2, 3.16\% and 3.05\% of sample weight for sample 5 and 6 respectively were lost during the first 15 days, with only $0.09 \%$ loss for the remaining 60 days for both samples, thus indicating that the samples were completely dry.

Other details about the concrete cubes, including volume, oven dry density, lab dry density and specific gravity were computed using Equations 5-2 through 5-4. Table 5-2 summarizes weight and computed data for the two cubes. Variation of sample weight with time is plotted in Figure 5-10, showing that most of the moisture was lost during the first 15 days of oven drying. 
Table 5-2 Moisture content summary table

\begin{tabular}{|c|c|c|c|c|c|c|}
\hline \multirow[b]{2}{*}{$\begin{array}{c}\text { Days in } \\
\text { Oven }\end{array}$} & \multicolumn{3}{|c|}{ Sample \#5 } & \multicolumn{3}{|c|}{ Sample \#6 } \\
\hline & $\begin{array}{c}\text { Weight, } w \\
\text { (g) }\end{array}$ & $\begin{array}{c}\% \text { of } \\
\text { Original } \\
\text { Weight }\end{array}$ & $\begin{array}{c}\% \\
\text { Change }\end{array}$ & $\begin{array}{c}\text { Weight, } w \\
\text { (g) }\end{array}$ & $\begin{array}{c}\% \text { of } \\
\text { Original } \\
\text { Weight }\end{array}$ & $\begin{array}{c}\% \\
\text { Change }\end{array}$ \\
\hline 0 & 960.0 & 100.00 & 0.00 & 996.1 & 100.00 & 0.00 \\
\hline 15 & 929.7 & 96.84 & 3.16 & 965.7 & 96.95 & 3.05 \\
\hline 30 & 929.5 & 96.82 & \multirow{4}{*}{0.09} & 965.5 & 96.93 & \multirow{4}{*}{0.09} \\
\hline 45 & 928.9 & 96.76 & & 965.2 & 96.90 & \\
\hline 60 & 928.9 & 96.76 & & 964.9 & 96.87 & \\
\hline 75 & 928.8 & 96.75 & & 964.8 & 96.86 & \\
\hline \multicolumn{3}{|c|}{ Moisture Content, $w(\%)$} & 3.36 & & & 3.24 \\
\hline \multicolumn{3}{|c|}{ Average Moisture Content, $w(\%)$} & \multicolumn{4}{|c|}{3.30} \\
\hline \multicolumn{3}{|c|}{ Volume, $V\left(\mathrm{~m}^{3}\right)$} & \multicolumn{4}{|c|}{0.0004425} \\
\hline \multicolumn{3}{|c|}{ Oven Dry Density, $\gamma_{d}\left(\mathrm{~kg} / \mathrm{m}^{3}\right)$} & 2099 & & & 2181 \\
\hline \multicolumn{3}{|c|}{ Lab Dry Density, $\gamma_{\text {Lab dry }}\left(\mathrm{kg} / \mathrm{m}^{3}\right)$} & 2170 & & & 2251 \\
\hline \multicolumn{3}{|c|}{ Specific Gravity (Oven Dry) } & 2.10 & & & 2.18 \\
\hline
\end{tabular}

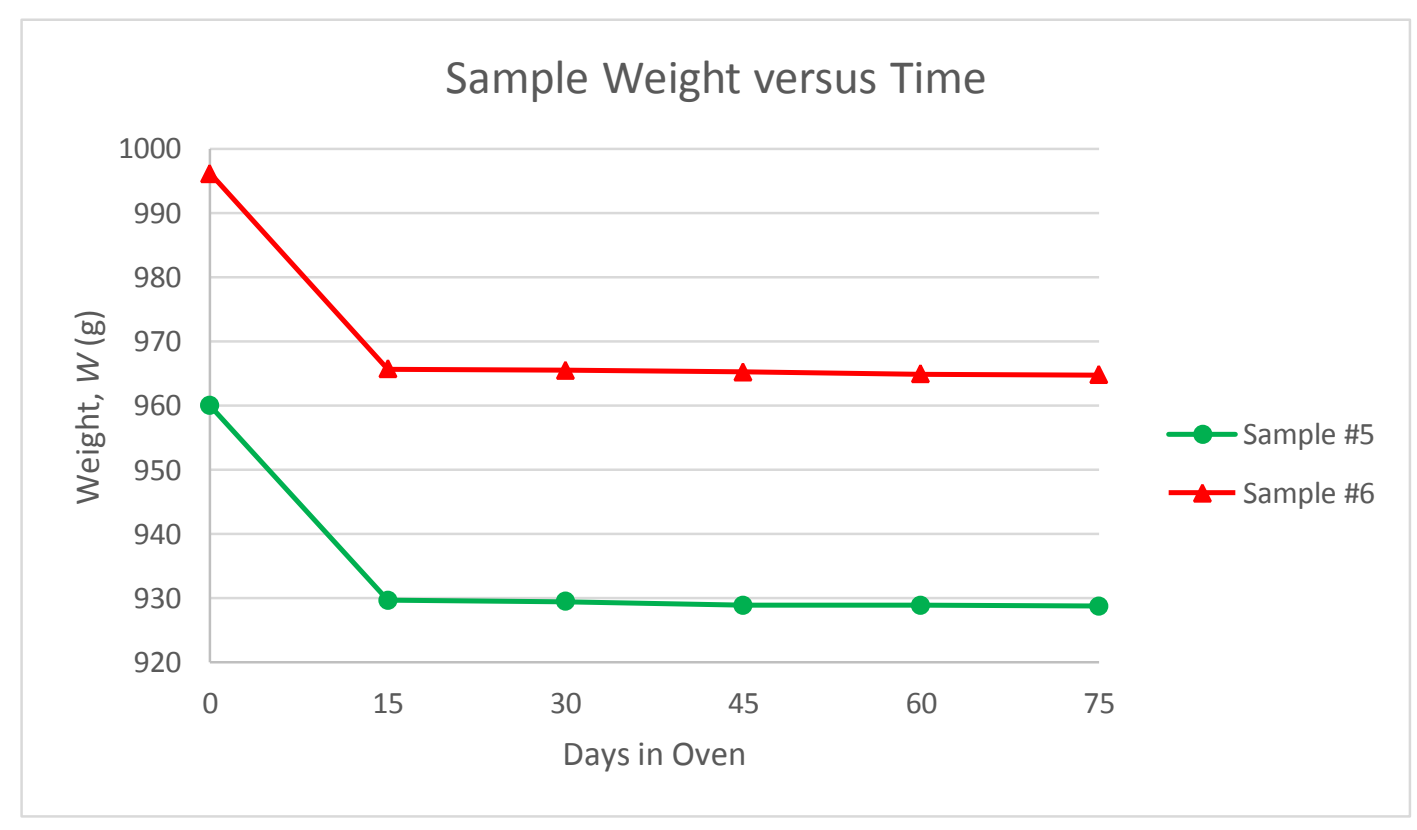

Figure 5-10 Variation of sample weight with time during drying 
Lab dry density $\left(\gamma_{\text {Lab dry }}, \mathrm{kg} / \mathrm{m}^{3}\right)=\frac{\text { Lab dry weight }(\mathrm{kg})}{\text { Volume of cube }\left(\mathrm{m}^{3}\right)}$

Oven dry density $\left(\gamma_{d}, \mathrm{~kg} / \mathrm{m}^{3}\right)=\frac{\text { Oven dry weight }(\mathrm{kg})}{\text { Volume of cube }\left(\mathrm{m}^{3}\right)}$

$$
\begin{aligned}
\text { Specific gravity } & =\frac{\text { Oven dry density }\left(\gamma_{d}, \mathrm{~kg} / \mathrm{m}^{3}\right)}{\text { Density of water }\left(\gamma_{w}, \mathrm{~kg} / \mathrm{m}^{3}\right)} \\
& =\frac{\text { Oven dry density }\left(\gamma_{d}, \mathrm{~kg} / \mathrm{m}^{3}\right)}{1,000\left(\mathrm{~kg} / \mathrm{m}^{3}\right)}
\end{aligned}
$$

Equation 4-4 from the previous chapter was used, together with the lab dry moisture content as mentioned previously to compute the moisture content of the cubes at each data point. The moisture content of the cubes at day 70 after casting (see Table 5-1) was found to be $2.66 \%$ and $2.60 \%$ for sample 5 and 6 respectively. The average of these two moisture contents (2.63\%) was used in computing the moisture content of samples $1,2,3$, and 4 in section 4.2.1 as discussed already. Figure 5-11 compares the moisture contents of samples $1,2,3,4,5$ and 6 , and the curves are very close to each other.

Oven dry specific gravity for the samples was found to be consistent, with 2.10 and 2.18 for sample 5 and 6 respectively. Resistance and resistivity data for sample R1 and R2, along with their variation with moisture content, will be analyzed in the next section. 


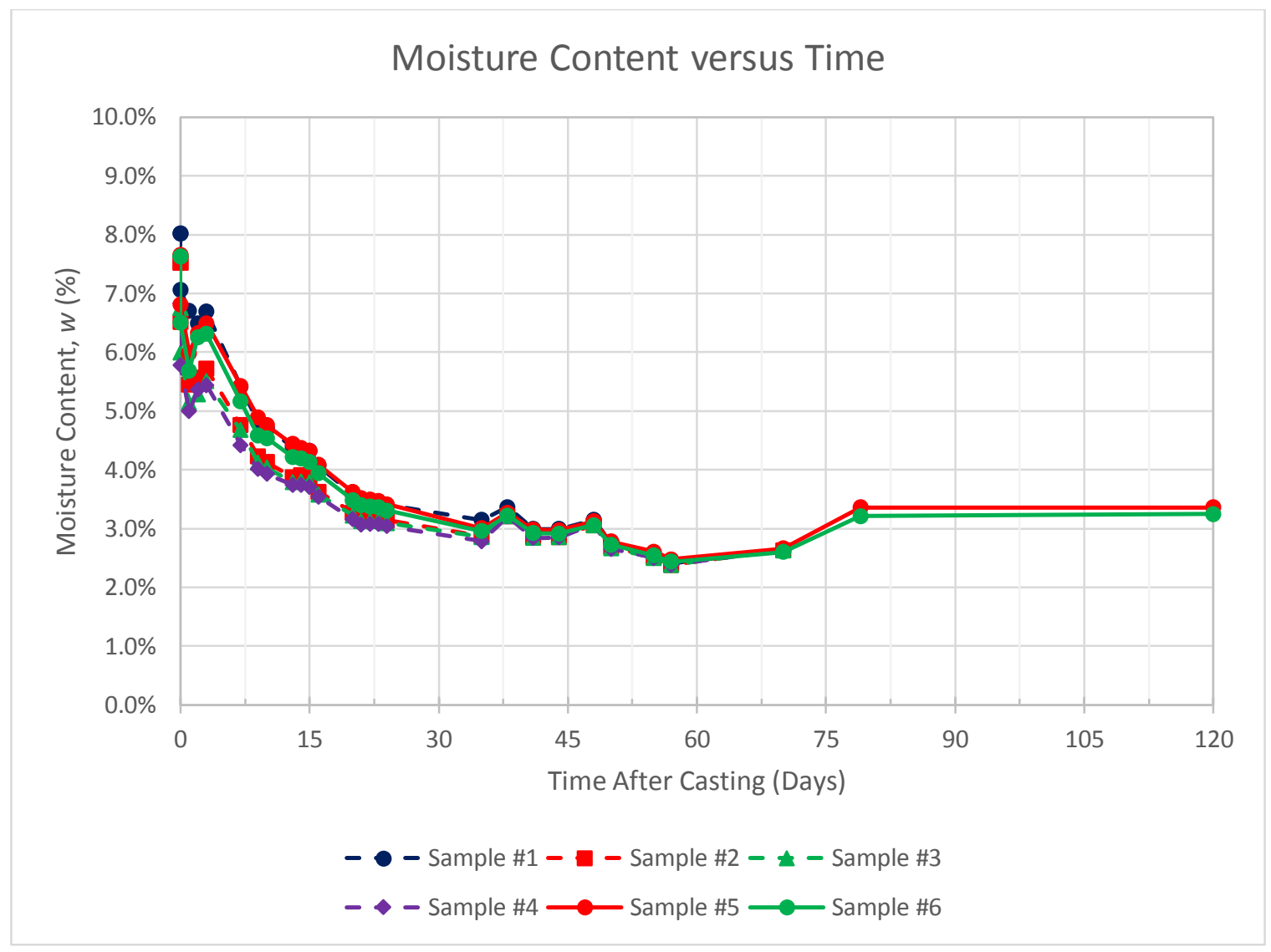

Figure 5-11 Moisture content variations for samples 1 through 6

\subsubsection{Resistance and Resistivity}

Weight and resistance data was collected during the curing stage of samples R1 and R2 to determine how their variations compare with that of samples $1,2,3$, and 4 . The data was collected for over 50 days from the day of cube casting. This data is presented in Table 5-3.

Weight of concrete, W, was calculated from Equation 5-5

$W=W_{\text {Total }}-W_{\text {Plates } \& \text { connectors }}$

Weight of plates and connectors ( $\left.\mathrm{W}_{\text {Plates \& connectors }}\right)$ for each sample is presented in Table $5-4$. 
Table 5-3 Data for resistance sensors during curing

\begin{tabular}{|c|c|c|c|c|c|c|c|c|}
\hline \multirow[b]{2}{*}{$\begin{array}{c}\text { Time } \\
\text { (Days) }\end{array}$} & \multicolumn{4}{|c|}{ Sample \#R1 } & \multicolumn{4}{|c|}{ Sample \#R2 } \\
\hline & $\begin{array}{l}\text { Weight, } \\
W_{\text {Total }} \text { (g) }\end{array}$ & $\begin{array}{c}\text { Weight, W } \\
\text { (g) }\end{array}$ & $\begin{array}{c}\text { Resistance, } \\
R(\mathrm{k} \Omega)\end{array}$ & $\begin{array}{c}\text { Resistivity, } \\
\rho \text { (k } \Omega . \mathrm{m})\end{array}$ & $\begin{array}{l}\text { Weight, } \\
W_{\text {Total }} \text { (g) }\end{array}$ & $\begin{array}{c}\text { Weight, W } \\
\text { (g) }\end{array}$ & $\begin{array}{c}\text { Resistance, } \\
R(\mathrm{k} \Omega)\end{array}$ & $\begin{array}{c}\text { Resistivity, } \\
\rho \text { (k } \Omega . \mathrm{m})\end{array}$ \\
\hline 1 & 2442.9 & 2137.0 & 8.3 & 1.3 & 2480.9 & 2480.9 & 6.8 & 1.0 \\
\hline 2 & 2436.3 & 2436.3 & 11.1 & 1.7 & 2475.0 & 2475.0 & 5.6 & 0.9 \\
\hline 8 & 2417.9 & 2410.1 & 65.5 & 10.0 & 2460.0 & 2460.0 & 43.4 & 6.6 \\
\hline 9 & 2416.5 & 2411.4 & 94.6 & 14.4 & 2458.4 & 2458.4 & 53.7 & 8.2 \\
\hline 10 & 2414.8 & 2401.9 & 109.4 & 16.7 & 2457.2 & 2457.2 & 71.1 & 10.8 \\
\hline 22 & 2403.4 & 2119.5 & 393.5 & 60.0 & 2447.0 & 2447.0 & 365.7 & 55.7 \\
\hline 42 & 2395.8 & 2395.8 & 572.2 & 87.2 & 2439.7 & 2439.7 & 539.3 & 82.2 \\
\hline 44 & 2394.0 & 2394.0 & 620.2 & 94.5 & 2438.0 & 2438.0 & 640.6 & 97.6 \\
\hline 57 & 2392.7 & 2392.7 & 651.7 & 99.3 & 2436.5 & 2436.5 & 787.0 & 119.9 \\
\hline
\end{tabular}

Table 5-4 Weight of plates and connectors for samples $R 1$ and R2

\begin{tabular}{|c|c|}
\hline Sample Number & Weight of plates and connectors $(\mathrm{g})$ \\
\hline R1 & 273.1 \\
\hline R2 & 271.0 \\
\hline
\end{tabular}


From Equation 4-6,

$$
\frac{A}{L}=\frac{(3 \times 2.54)^{2}}{(1.50 \times 2.54)}=\frac{9 \times 2.54}{1.50} \approx 15.24 \mathrm{~cm}=0.1524 \mathrm{~m}
$$

Therefore;

$$
\rho=R \frac{A}{L}=0.1524 R(k \Omega . m)
$$

Resistivity versus time plots for the sensors during the curing stage were produced in Figure 5-12. The plots were also compared to what was obtained for samples 1 through 4 in Chapter 4 and presented in Figure 5-13. It is observed from this plot that sensors R1 and $\mathrm{R} 2$ has resistivity values that are consistent with that of sensors 1,2, 3, and 4 even though the cubes were produced at different times with different concrete batches (but with same concrete mix).

The sensors (R1 and R2) were soaked afterwards to ensure that the pores of the concrete became saturated with water. The sensors were removed from the water for laboratory monitoring after two weeks. Weight and resistance measurements were carried out on these samples to determine daily variations of these parameters as the senor concrete dried under laboratory temperature. Data collection on the samples was done continuously for 368 days and 365 days for R1 and R2 respectively. The collected data was then analyzed to generate baseline values and calibration curves for corrosion data interpretation as discussed below.

A summary of the raw data collected from the samples is presented in Table 5-5 and the complete data set is presented in Appendix B. Weight of concrete and resistivity of the samples were then calculated using Equation 5-5 and 5-6 respectively. Weight of plates and connectors for each sensor is presented in Table 5-6. For sample R1, the connector had an issue and had to be replaced after 8 days, leading to a change in connector weight after 8 days as shown in Table 5-6. 


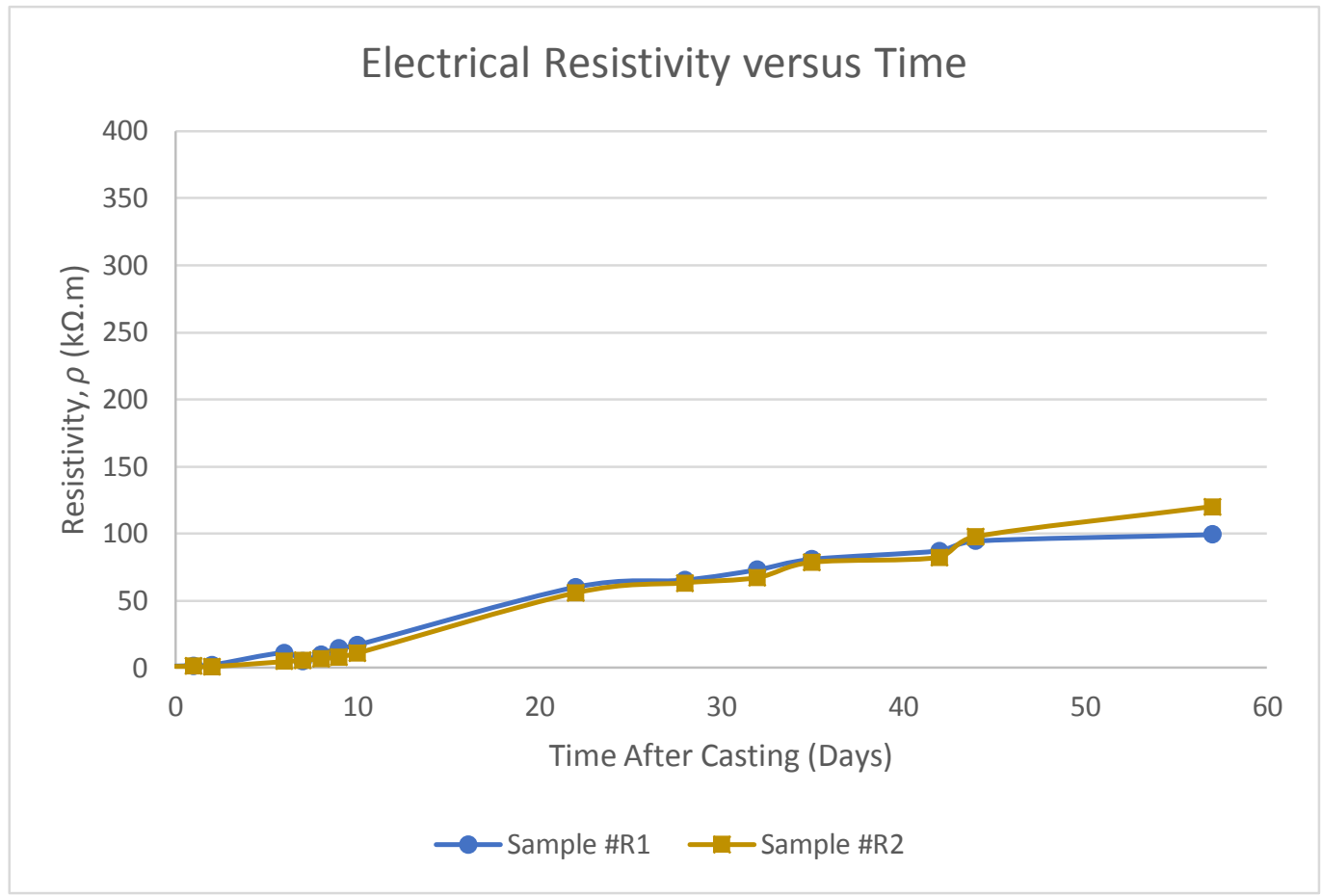

Figure 5-12 Variation of electrical resistivity with time for $R 1$ and $R 2$

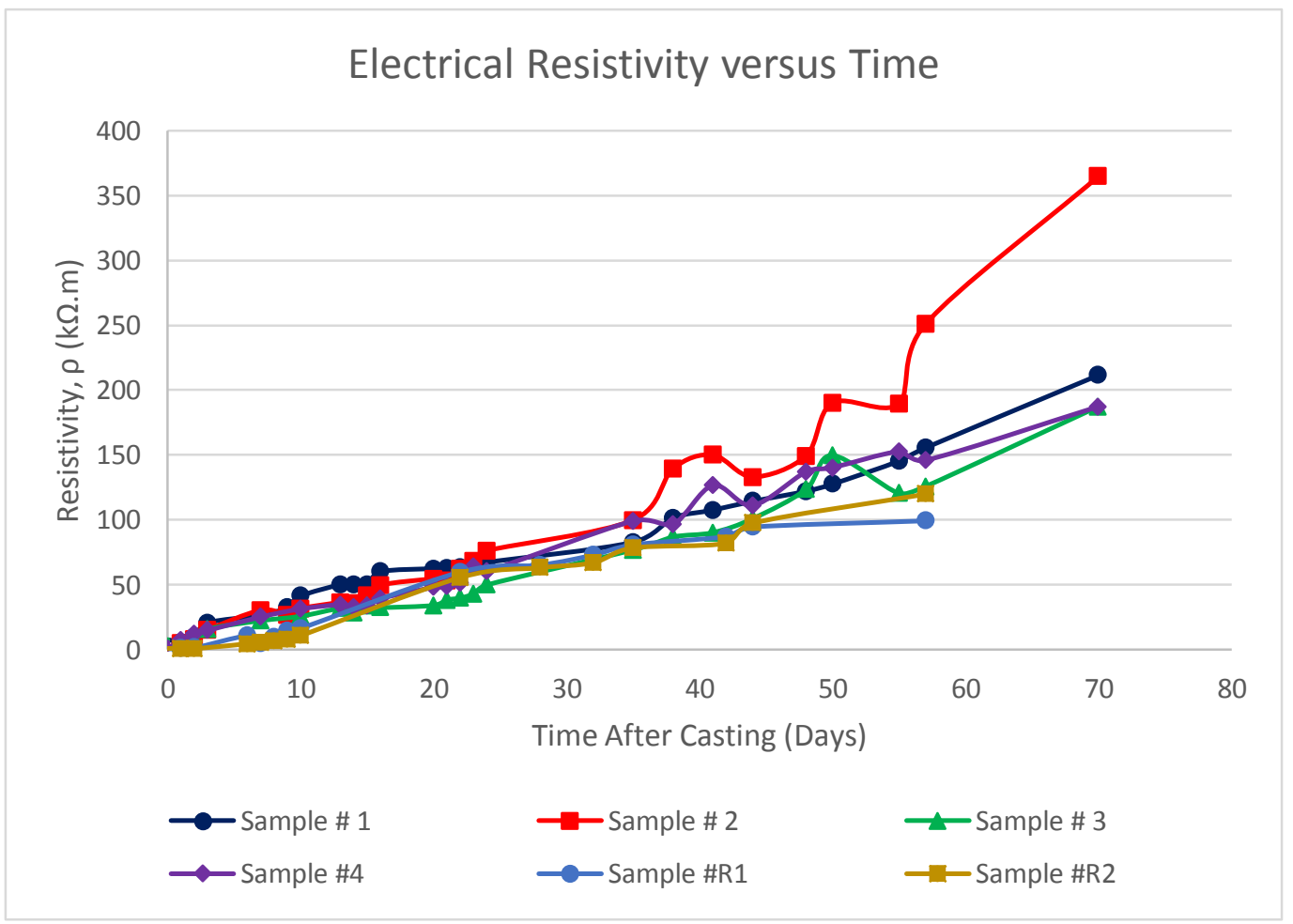

Figure 5-13 Electrical resistivity versus time comparism for preliminary design and R1, $R 2$ 
Table 5-5 Summary of weight and electrical resistance data

\begin{tabular}{|c|c|c|c|c|}
\hline \multirow[b]{2}{*}{$\begin{array}{l}\text { Time } \\
\text { (Days) }\end{array}$} & \multicolumn{2}{|c|}{ Sample \#R1 } & \multicolumn{2}{|c|}{ Sample \#R2 } \\
\hline & $\begin{array}{l}\text { Weight, } \\
W_{\text {total }} \text { (g) }\end{array}$ & $\begin{array}{c}\text { Resistance, } \\
R(\mathrm{k} \Omega)\end{array}$ & $\begin{array}{l}\text { Weight, } \\
W_{\text {total }} \text { (g) }\end{array}$ & $\begin{array}{c}\text { Resistance, } \\
\quad R(\mathrm{k} \Omega)\end{array}$ \\
\hline 0 & 2568.5 & 3.4 & 2597.6 & 1.3 \\
\hline 10 & 2512.3 & 50.2 & 2539.0 & 18.0 \\
\hline 20 & 2495.0 & 77.8 & 2517.7 & 105.9 \\
\hline 30 & 2486.8 & 276.7 & 2505.7 & 126.1 \\
\hline 40 & 2481.2 & 437.2 & 2498.2 & 352.2 \\
\hline 50 & 2477.5 & 531.6 & 2493.1 & 390.8 \\
\hline 60 & 2474.6 & 580.3 & 2488.9 & 529.8 \\
\hline 70 & 2472.5 & 646.0 & 2485.9 & 603.4 \\
\hline 80 & 2470.7 & 701.0 & 2483.2 & 658.2 \\
\hline 90 & 2468.8 & 712.0 & 2480.9 & 712.0 \\
\hline 100 & 2467.5 & 745.0 & 2478.8 & 732.0 \\
\hline 110 & 2465.6 & 760.0 & $2475.0^{1}$ & $754.0^{1}$ \\
\hline 120 & 2464.2 & 772.0 & 2471.8 & 762.0 \\
\hline 130 & 2462.3 & 788.0 & $2469.8^{1}$ & $782.0^{1}$ \\
\hline 140 & 2459.1 & 799.0 & 2468.2 & 796.0 \\
\hline 160 & $2454.5^{1}$ & $842.0^{1}$ & 2465.6 & 804.0 \\
\hline 180 & $2451.2^{1}$ & $897.0^{1}$ & $2462.0^{1}$ & $817.0^{1}$ \\
\hline 200 & 2448.2 & 936.0 & $2458.8^{1}$ & $930.0^{1}$ \\
\hline 220 & 2445.0 & 992.0 & 2457.1 & 1042.0 \\
\hline 240 & 2443.1 & 1151.0 & 2457.3 & 1089.0 \\
\hline 260 & 2443.0 & 1301.0 & 2458.1 & 1240.0 \\
\hline 280 & 2442.8 & 1378.0 & 2457.9 & 1244.0 \\
\hline 300 & $2445.1^{1}$ & $1448.0^{1}$ & 2460.0 & 1228.0 \\
\hline 320 & $2445.5^{1}$ & $1480.0^{1}$ & $2461.0^{1}$ & $1082.0^{1}$ \\
\hline 340 & 2447.1 & 1349.0 & $2461.1^{1}$ & $1137.0^{1}$ \\
\hline 360 & 2448.1 & 1236.0 & 2461.3 & 1120.0 \\
\hline 365 & 2448.3 & 1207.0 & 2461.3 & 1126.0 \\
\hline
\end{tabular}

Table 5-6 Weight of plates and connectors for R1 and R2

\begin{tabular}{|c|c|}
\hline Sample Number & Weight of plates and connectors $(\mathrm{g})$ \\
\hline R1 & 273.1 for first 8 days, then 305.9 afterwards \\
\hline R2 & 283.9 \\
\hline
\end{tabular}

${ }^{1}$ Values in italics mean data for a day before or after the stated day is used instead in this table. However, the plot is based on the exact day of the measurement. 
The variation of electrical resistivity values for the sensors over one year period is presented in Figure 5-14. The electrical resistivity values of the two sensors were observed to be consistent with each other over the course of the year. The resistivity fluctuation towards the end of the curve is due to fluctuation in the atmospheric humidity in the laboratory.

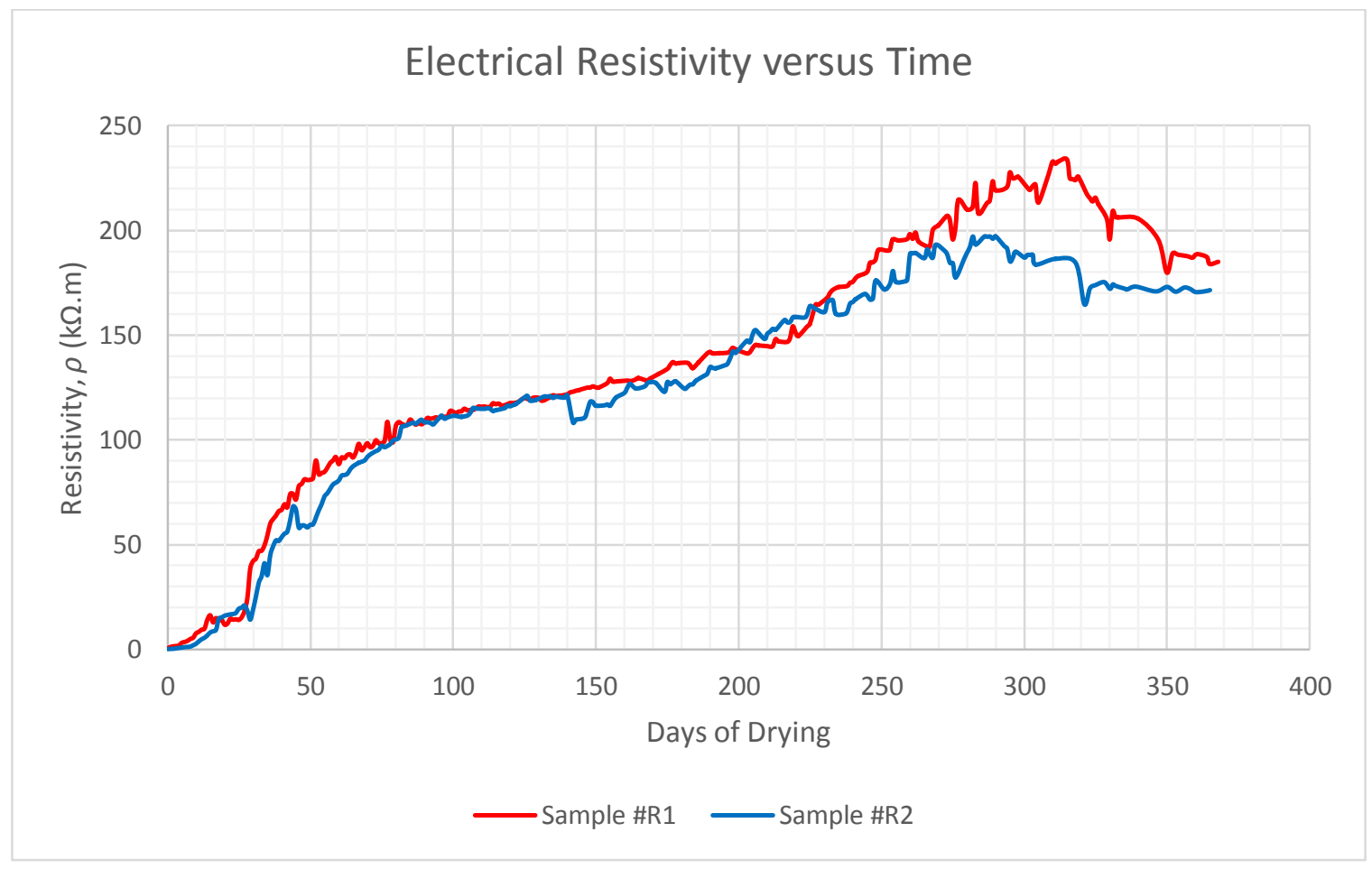

Figure 5-14 Variation of electrical resistivity with time

Moisture content of each cube (sensors R1 and R2) at the various data points was computed using Equation 4-4 and the lab dry moisture content ( $w_{\text {Lab dry }}$ ) of 3.30\% computed in section 5.4.1 which corresponds to the final weight of the samples. Resistivity for each cube was also computed using Equation 5-6. A summary of sample weight, moisture content and resistivity data is presented in Table 5-7 and the complete data set is available in Appendix B. The variation of concrete electrical resistivity with moisture content is plotted and shown in Figure 5-15. 
Table 5-7 Summary of weight, moisture and resistivity for $R 1$ and $R 2$

\begin{tabular}{|c|c|c|c|c|c|c|}
\hline \multirow[b]{2}{*}{$\begin{array}{l}\text { Time } \\
\text { (Days) }\end{array}$} & \multicolumn{3}{|c|}{ Sample \#R1 } & \multicolumn{3}{|c|}{ Sample \#R2 } \\
\hline & $\begin{array}{l}\text { Weight, } \\
\text { W (g) }\end{array}$ & $\begin{array}{c}\text { Moisture } \\
\text { Content, } w\end{array}$ & $\begin{array}{c}\text { Resistivity, } \\
\rho \text { (k } \Omega . \mathrm{m})\end{array}$ & $\begin{array}{l}\text { Weight, } \\
\text { W (g) }\end{array}$ & $\begin{array}{c}\text { Moisture } \\
\text { Content, w }\end{array}$ & $\begin{array}{c}\text { Resistivity, } \\
\rho \text { (k } \Omega . \mathrm{m})\end{array}$ \\
\hline 0 & 2295.4 & 0.107 & 0.5 & 2313.7 & 0.098 & 0.2 \\
\hline 10 & 2206.4 & 0.064 & 7.7 & 2255.1 & 0.070 & 2.7 \\
\hline 20 & 2189.1 & 0.056 & 11.9 & 2233.8 & 0.060 & 16.1 \\
\hline 30 & 2180.9 & 0.052 & 42.2 & 2221.8 & 0.054 & 19.2 \\
\hline 40 & 2175.3 & 0.049 & 66.6 & 2214.3 & 0.051 & 53.7 \\
\hline 50 & 2171.6 & 0.047 & 81.0 & 2209.2 & 0.048 & 59.6 \\
\hline 60 & 2168.7 & 0.046 & 88.4 & 2205.0 & 0.046 & 80.7 \\
\hline 70 & 2166.6 & 0.045 & 98.5 & 2202.0 & 0.045 & 92.0 \\
\hline 80 & 2164.8 & 0.044 & 106.8 & 2199.3 & 0.043 & 100.3 \\
\hline 90 & 2162.9 & 0.043 & 108.5 & 2197.0 & 0.042 & 108.5 \\
\hline 100 & 2161.6 & 0.042 & 113.5 & 2194.9 & 0.041 & 111.6 \\
\hline 110 & 2159.7 & 0.041 & 115.8 & $2191.1^{1}$ & $0.039^{1}$ & $114.9^{1}$ \\
\hline 120 & 2158.3 & 0.041 & 117.7 & 2187.9 & 0.038 & 116.1 \\
\hline 130 & 2156.4 & 0.040 & 120.1 & $2185.9^{1}$ & $0.037^{1}$ & $119.2^{1}$ \\
\hline 140 & 2153.2 & 0.038 & 121.8 & 2184.3 & 0.036 & 121.3 \\
\hline 160 & $2148.6^{1}$ & $0.036^{1}$ & $128.3^{1}$ & 2181.7 & 0.035 & 122.5 \\
\hline 180 & $2145.3^{1}$ & $0.034^{1}$ & $136.7^{1}$ & $2178.1^{1}$ & $0.033^{1}$ & $124.5^{1}$ \\
\hline 200 & 2142.3 & 0.033 & 142.6 & $2174.9^{1}$ & $0.032^{1}$ & $141.7^{1}$ \\
\hline 220 & 2139.1 & 0.031 & 151.2 & 2173.2 & 0.031 & 158.8 \\
\hline 240 & 2137.2 & 0.030 & 175.4 & 2173.4 & 0.031 & 166.0 \\
\hline 260 & 2137.1 & 0.030 & 198.3 & 2174.2 & 0.031 & 189.0 \\
\hline 280 & 2136.9 & 0.030 & 210.0 & 2174.0 & 0.031 & 189.6 \\
\hline 300 & $2139.2^{1}$ & $0.031^{1}$ & $220.7^{1}$ & 2176.1 & 0.032 & 187.1 \\
\hline 320 & $2139.6^{1}$ & $0.032^{1}$ & $225.6^{1}$ & $2177.1^{1}$ & $0.033^{1}$ & $164.9^{1}$ \\
\hline 340 & 2141.2 & 0.032 & 205.6 & $2177.2^{1}$ & $0.033^{1}$ & $173.3^{1}$ \\
\hline 360 & 2142.2 & 0.033 & 188.4 & 2177.4 & 0.033 & 170.7 \\
\hline 365 & 2142.4 & 0.033 & 183.9 & 2177.4 & 0.033 & 171.6 \\
\hline
\end{tabular}

${ }^{1}$ Values in italics mean data for a day before or after the stated day is used instead in this table. However, the plot is based on the exact day of the measurement. 


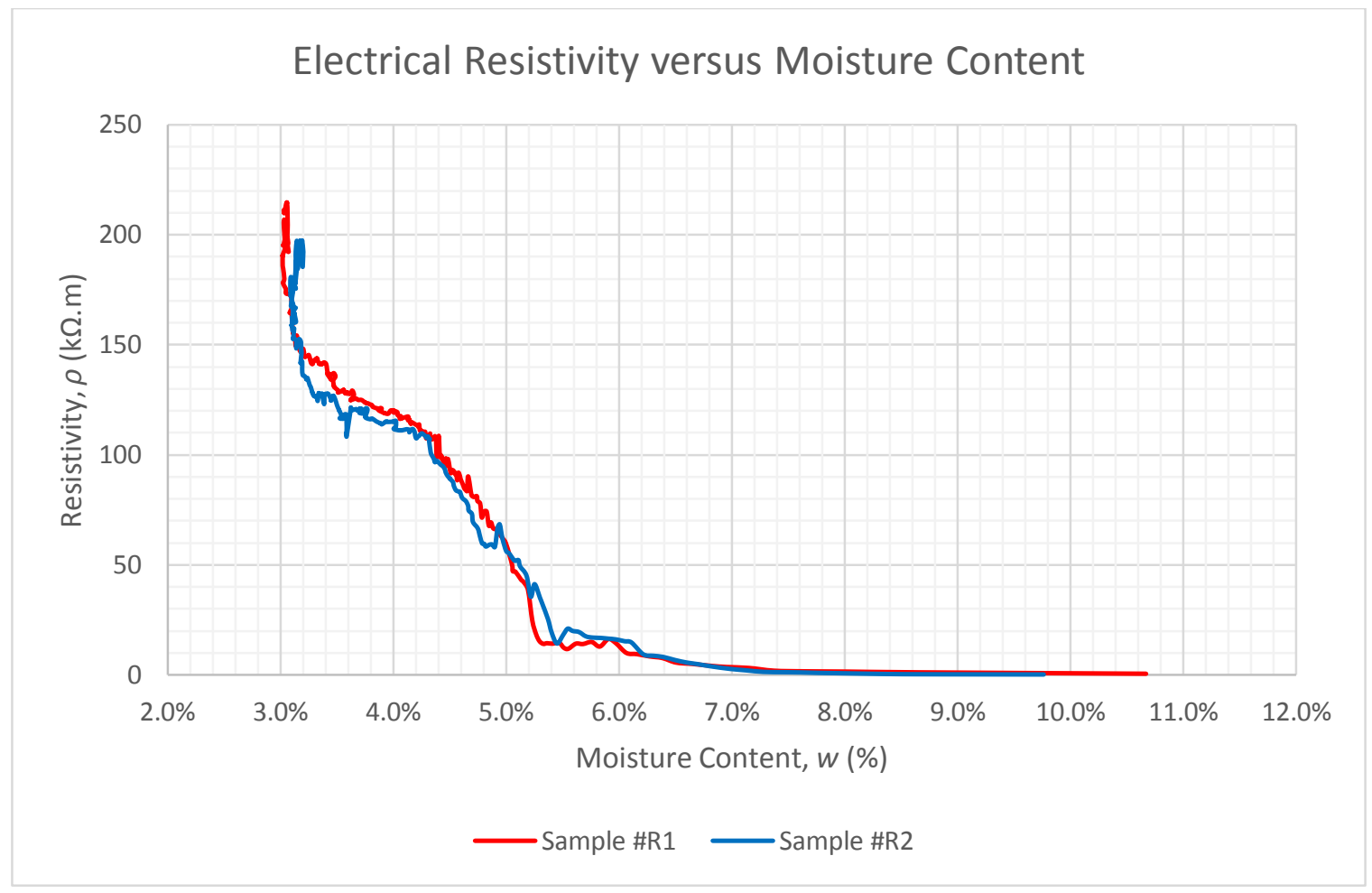

Figure 5-15 Variation of concrete electrical resistivity with moisture content

Figure 5-15 shows two distinct regions, a low electrical resistivity region with a low slope above $5.5 \%$ moisture content and a high electrical resistivity region with a significantly higher slope below 5.5\% moisture content. In the latter region, the connectivity between water molecules in the concrete pores is lost, thus leading to a steep electrical resistivity curve.

From Table $3-2 \mathrm{c}$ in section 3.3, corrosion activity is only likely if the resistivity of the concrete goes below $0.2 \mathrm{k} \Omega . \mathrm{m}(20 \mathrm{k} \Omega . \mathrm{cm})$. This means corrosion activity was unlikely in the two cubes used in this study during the course of the study since the resistivity value never dropped below the $0.2 \mathrm{k} \Omega$.m threshold. This is because the sample was new and had not been exposed to carbonation or chlorides in the field. Some researchers have questioned the $0.2 \mathrm{k} \Omega . \mathrm{m}(20 \mathrm{k} \Omega . \mathrm{cm})$ threshold and have suggested that corrosion activity is likely if the resistivity value goes below $1 \mathrm{k} \Omega . \mathrm{m}(100 \mathrm{k} \Omega . \mathrm{cm})$, as shown in Table 3-2d. 


\subsubsection{Temperature and Humidity}

Similar to samples R1 and R2, the sample T-H1 (encasing the temperature/humidity sensor) was also soaked for a period of two weeks to ensure that the pores of the concrete became saturated. The sensor was then allowed to dry in the laboratory and monitored for weight, temperature and humidity variations for 368 days. Commercially available SainSmart UNO ATMEGA328P-PU ATMEGA8U2 Microcontroller for Arduino (model SKU: 20-011-900) was used, along with a computer, for obtaining data from the temperature/humidity sensor. The microcontroller and data collection set up are shown in Figures 5-16 and 5-17 respectively. The temperature/humidity sensor has a temperature accuracy of $\pm 0.5^{\circ} \mathrm{C}$. The accuracy for humidity is within $\pm 4.5 \% \mathrm{RH}$.

It was observed during the data collection stage that the humidity sensor records values higher than $100 \%$ when the sensor is saturated; values as high as $106.15 \%$ were observed. Such values were recorded as $99.99 \%$ throughout this research. Table 5-8 summarizes the data obtained from this sensor and the complete data set is presented in Appendix B.

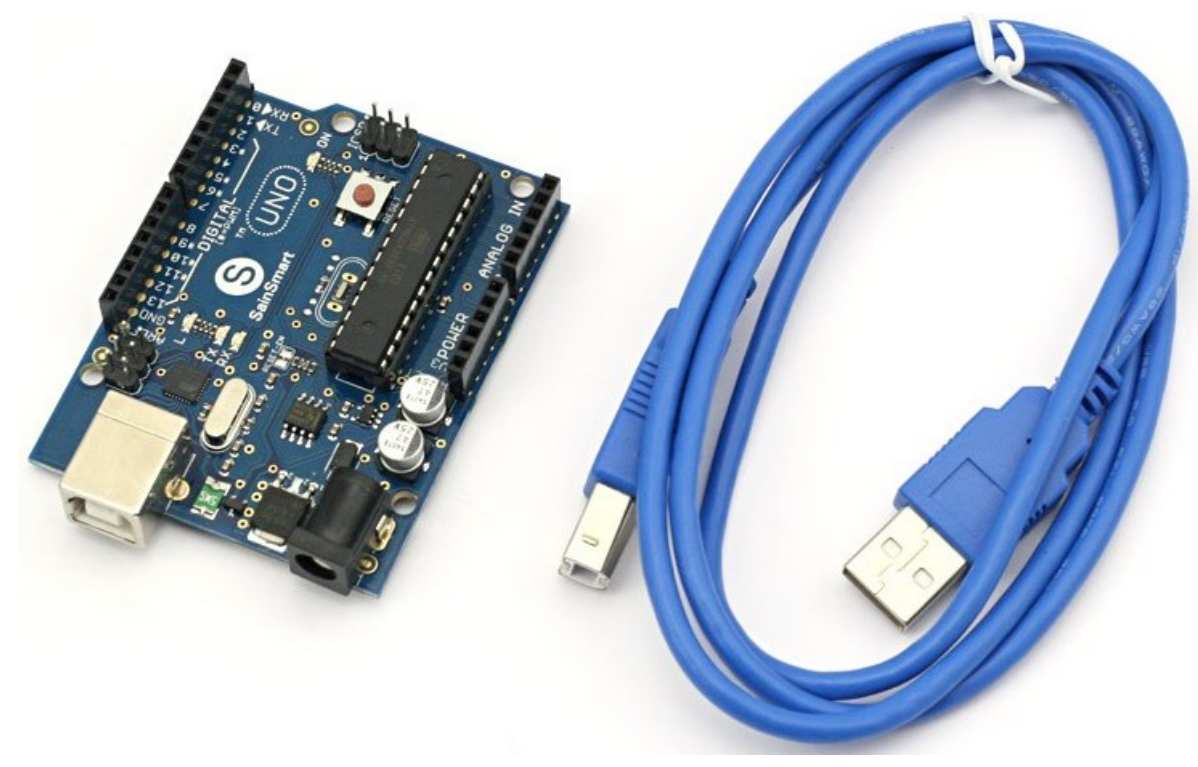

Figure 5-16 Microcontroller for temperature/humidity data collection (SainSmart 2015) 


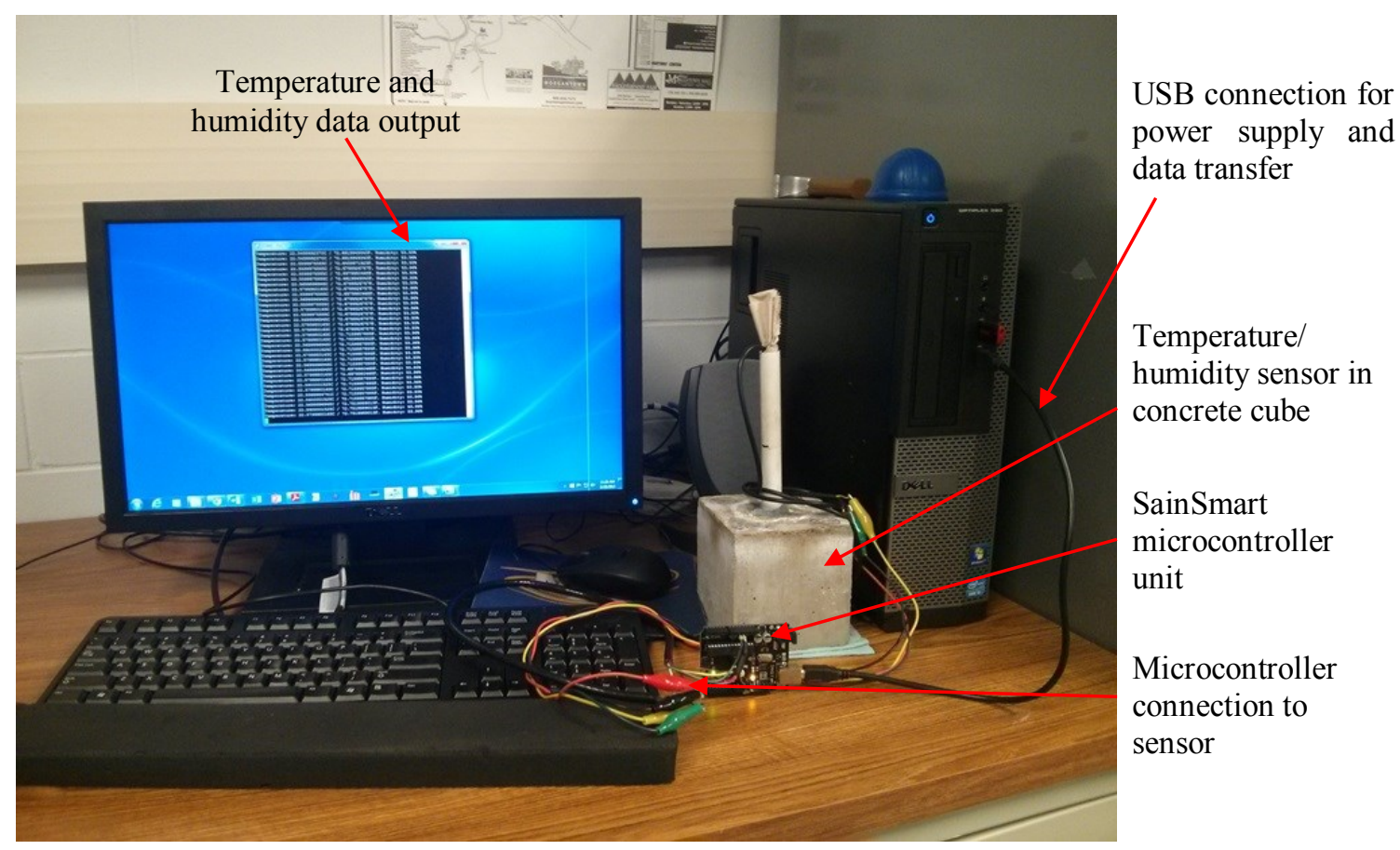

(a)

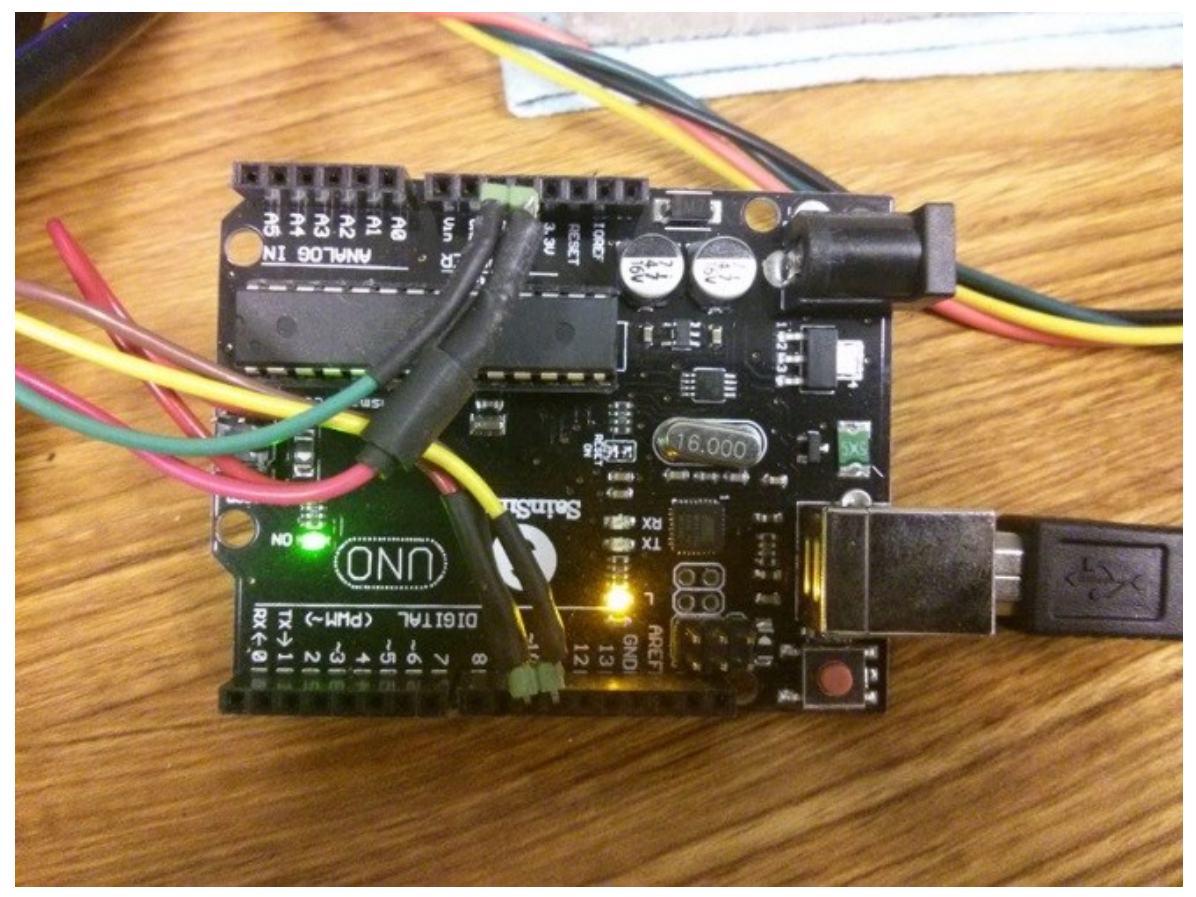

(b)

Figure 5-17 (a) Data collection set-up (b) Close-up view of microcontroller connections 
Table 5-8 Summary of temperature/humidity data

\begin{tabular}{|c|c|c|c|c|c|c|}
\hline \multirow{3}{*}{$\begin{array}{l}\text { Time } \\
\text { (Days) }\end{array}$} & \multicolumn{6}{|c|}{ Sample \#T-H1 } \\
\hline & \multirow{2}{*}{$\begin{array}{l}\text { Weight, } \\
W_{\text {Total }} \text { (g) }\end{array}$} & \multirow{2}{*}{$\begin{array}{c}\text { Weight, } w \\
\text { (g) }\end{array}$} & \multirow{2}{*}{$\begin{array}{l}\text { Moisture } \\
\text { Content, } w\end{array}$} & \multicolumn{2}{|c|}{ Temperature } & \multirow{2}{*}{$\begin{array}{l}\text { R. Humidity } \\
\text { (\%) }\end{array}$} \\
\hline & & & & $\left({ }^{\circ} \mathrm{C}\right)$ & $\left({ }^{\circ} \mathrm{F}\right)$ & \\
\hline 0 & 2537.3 & 2461.1 & 0.095 & 23.11 & 73.70 & 99.99 \\
\hline 10 & 2463.8 & 2387.6 & 0.062 & 23.10 & 73.65 & 99.99 \\
\hline 20 & 2449.0 & 2372.8 & 0.056 & 23.07 & 73.61 & 99.99 \\
\hline 30 & 2441.4 & 2365.2 & 0.052 & 23.12 & 73.71 & 99.99 \\
\hline 40 & 2436.1 & 2359.9 & 0.050 & 22.64 & 72.84 & 96.16 \\
\hline 50 & 2432.0 & 2355.8 & 0.048 & 23.13 & 73.71 & 92.43 \\
\hline 60 & 2429.0 & 2352.8 & 0.047 & 23.00 & 73.47 & 88.88 \\
\hline 70 & 2426.5 & 2350.3 & 0.045 & 23.21 & 73.87 & 86.05 \\
\hline 80 & 2424.5 & 2348.3 & 0.045 & 23.22 & 73.87 & 83.02 \\
\hline 90 & 2422.2 & 2346.0 & 0.044 & 22.74 & 73.00 & 79.73 \\
\hline 100 & 2420.6 & 2344.4 & 0.043 & 22.99 & 73.44 & 77.21 \\
\hline 110 & 2418.6 & 2342.4 & 0.042 & 22.45 & 72.12 & 74.24 \\
\hline 120 & 2417.2 & 2341.0 & 0.041 & 22.09 & 71.82 & 72.24 \\
\hline 130 & 2415.0 & 2338.8 & 0.040 & 22.46 & 72.50 & 69.25 \\
\hline 140 & 2411.7 & 2335.5 & 0.039 & 23.10 & 73.63 & 66.01 \\
\hline 160 & $2406.8^{1}$ & $2330.6^{1}$ & $0.037^{1}$ & $23.59^{1}$ & $74.52^{1}$ & $59.83^{1}$ \\
\hline 180 & $2403.2^{1}$ & $2327.0^{1}$ & $0.035^{1}$ & $22.27^{1}$ & $72.14^{1}$ & $53.51^{1}$ \\
\hline 200 & 2400.0 & 2323.8 & 0.034 & 23.84 & 75.00 & 49.02 \\
\hline 220 & 2396.8 & 2320.6 & 0.032 & 26.02 & 78.89 & 46.16 \\
\hline 240 & 2394.4 & 2318.2 & 0.031 & 23.25 & 73.90 & 42.06 \\
\hline 260 & 2394.0 & 2317.8 & 0.031 & 23.18 & 73.78 & 38.22 \\
\hline 280 & 2393.5 & 2317.3 & 0.031 & 24.15 & 75.52 & 36.33 \\
\hline 300 & $2395.5^{1}$ & $2319.3^{1}$ & $0.032^{1}$ & $23.28^{1}$ & $73.98^{1}$ & $41.00^{1}$ \\
\hline 320 & $2395.9^{1}$ & $2319.7^{1}$ & $0.032^{1}$ & $22.82^{1}$ & $73.11^{1}$ & $42.15^{1}$ \\
\hline 340 & 2397.4 & 2321.2 & 0.033 & 22.59 & 72.72 & 48.70 \\
\hline 360 & 2398.4 & 2322.2 & 0.033 & 23.05 & 75.56 & 53.53 \\
\hline 365 & 2398.5 & 2322.3 & 0.033 & 23.69 & 74.73 & 54.15 \\
\hline
\end{tabular}

${ }^{1}$ Values in italics mean data for a day before or after the stated day is used instead in this table. However, the plot is based on the exact day of the measurement. 
Temperature within the concrete was found to be fairly stable throughout the study period, since the sample was in the laboratory environment. The temperature fluctuation was within the range of $20.7-27.4^{\circ} \mathrm{C}$ and an average of $23.4^{\circ} \mathrm{C}$ as shown in Figure $5-18$.

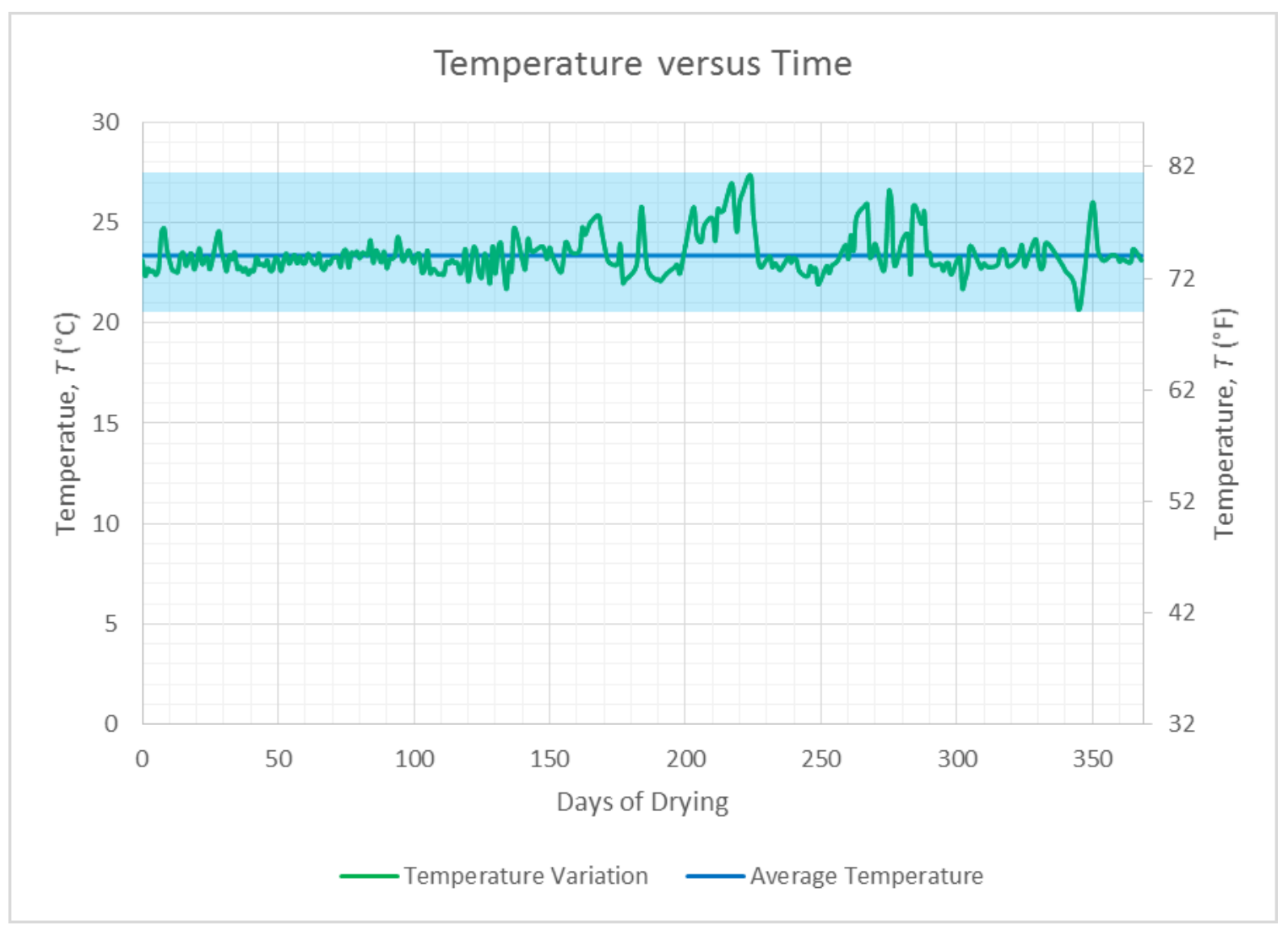

Figure 5-18 Variation of temperature within the concrete

Weight of concrete, W, in Table 5-8 was calculated using Equation 5-7. The weight of temperature/humidity sensor (including the plastic pipe and wire), $\mathrm{W}_{\text {Sensor \& connectors was }}$ measured and found to be $76.2 \mathrm{~g}$.

$W=W_{\text {Total }}-W_{\text {Sensor } \& \text { connectors }}$

Equation 4-4 from Chapter 4 was used in computing moisture content of the cube, with lab dry moisture content of $3.30 \%$, which corresponds to the final weight of the sample. 
The variation of humidity within the sample with time and with moisture content are plotted and shown in Figure 5-19 and 5-20 respectively.

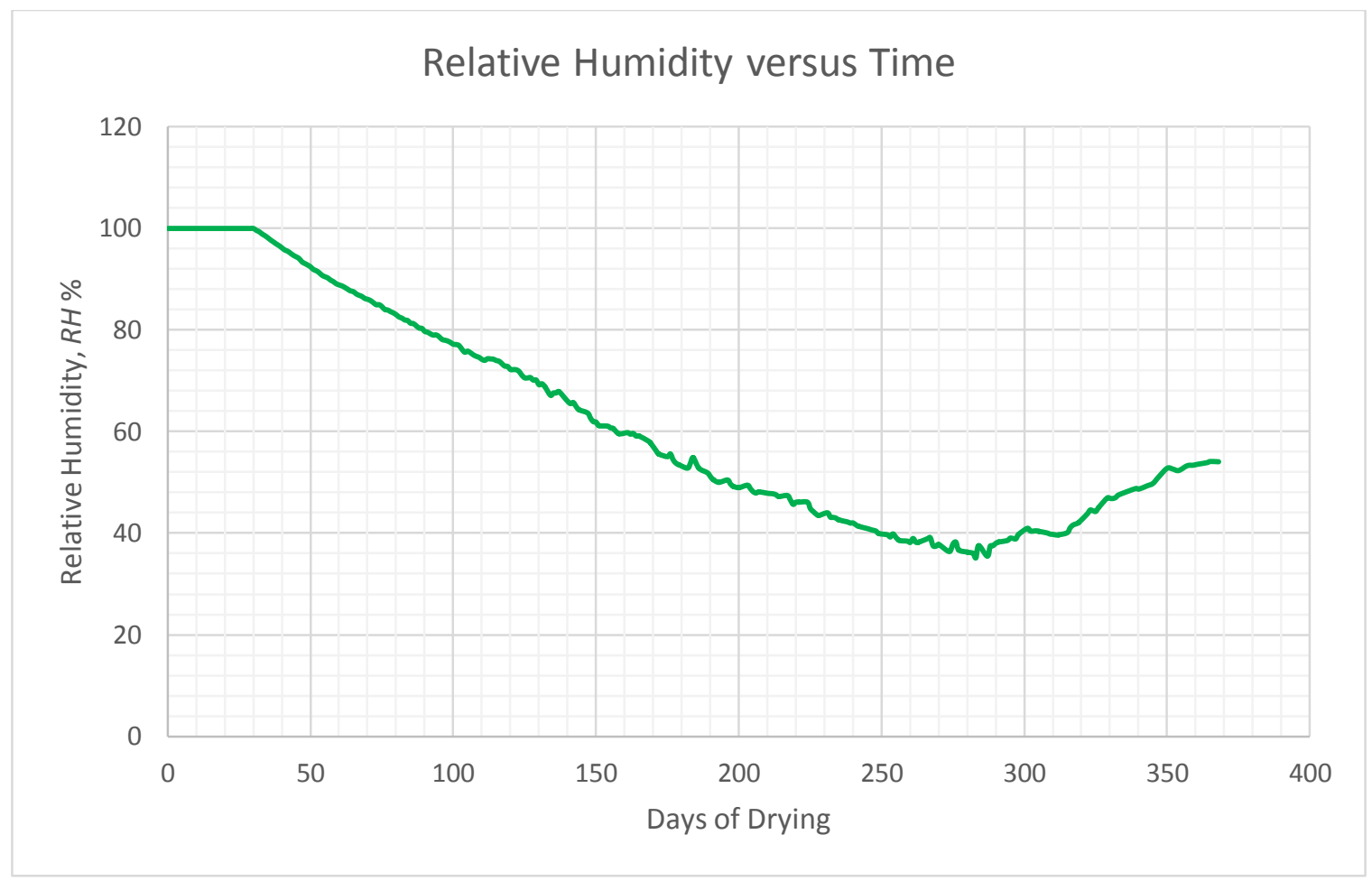

Figure 5-19 Variation of relative humidity within the cube 


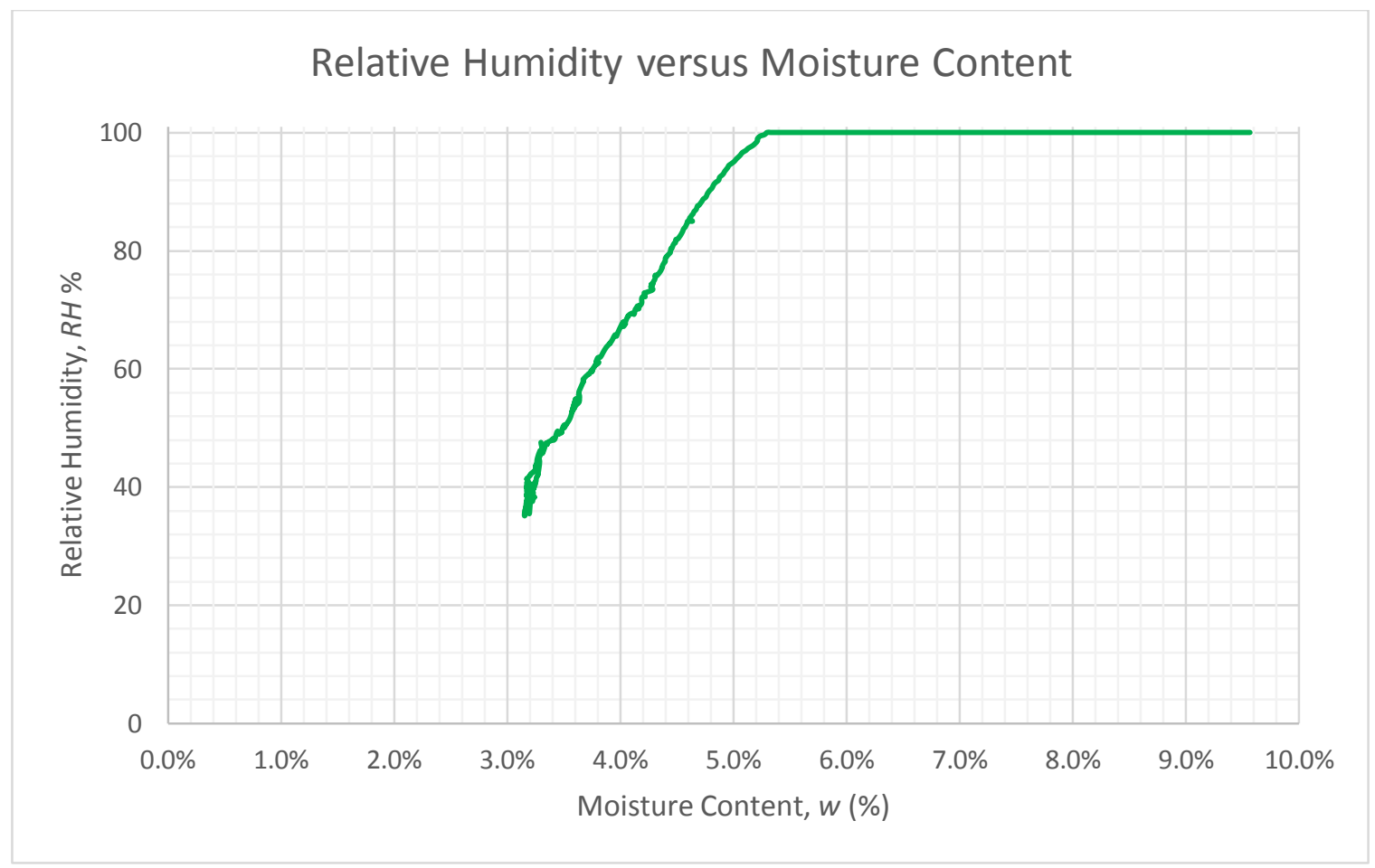

Figure 5-20 Variation of relative humidity with moisture content

The relative humidity remained constant for 30 days at $99.99 \%$ level when the concrete was saturated, and then decreased gradually at a constant rate for 250 days. Towards the end, the relative humidity increased slightly (Figure 5-19), which was due to a small rise in the laboratory humidity between cold winter months and warm spring months.

\subsubsection{Calibration Curve}

Data obtained from the electrical resistance sensors were combined with the one obtained from the temperature/humidity sensor to develop the calibration curve for field data interpretation. As has been discussed, the probability for corrosion of steel encased in concrete is minimal when the concrete resistivity is above $0.2 \mathrm{k} \Omega \mathrm{m}$ level. This is because high resistivity of concrete restricts the movement of ions and current through the concrete, thereby limiting corrosion.

In addition, the optimal relative humidity for corrosion of reinforced concrete is $70-80 \%$ as stated in the published literature (Bastidas-Arteaga and Stewart 2013, Li et al. 2009, and 
Shetty 2005). At humidity below $70 \%$, concrete becomes too dry and there is not enough moisture for the reduction reaction and ionic movement through the concrete, hence dry concrete does not corrode. Also, at humidity above $80 \%$, concrete becomes close to saturation and there is not enough oxygen for the reduction reaction to proceed and hence no corrosion takes place. The latter point is reinforced with Figure 6-3 in Chapter 6, where portions of the steel H-pile permanently under water showed no corrosion after decades of service in the field environment. The relative humidity range of $70-80 \%$ was found to correspond with moisture content of $4.05-4.35 \%$ for the $\mathrm{T}-\mathrm{H} 1$ sensor tested in the laboratory.

The likelihood of corrosion is very high when the relative humidity is between $70-80 \%$ and the concrete resistivity is below $0.2 \mathrm{k} \Omega$.m but minimal for all other conditions. The likelihood of corrosion is much lower when the relative humidity and concrete resistivity values are away from the optimal ranges. The above observations are shown in Figures 521 and 5-22.

Thus, there is a high potential for corrosion of the embedded steel if low resistivity values below $0.2 \mathrm{k} \Omega . \mathrm{m}$ is observed at the time when the relative humidity within the concrete is between $70-80 \%$ (moisture content of the concrete is around 4\%). Infiltration of chlorides into concrete can significantly lower the electrical resistivity value of concrete and increase the potential for corrosion of the embedded steel. 


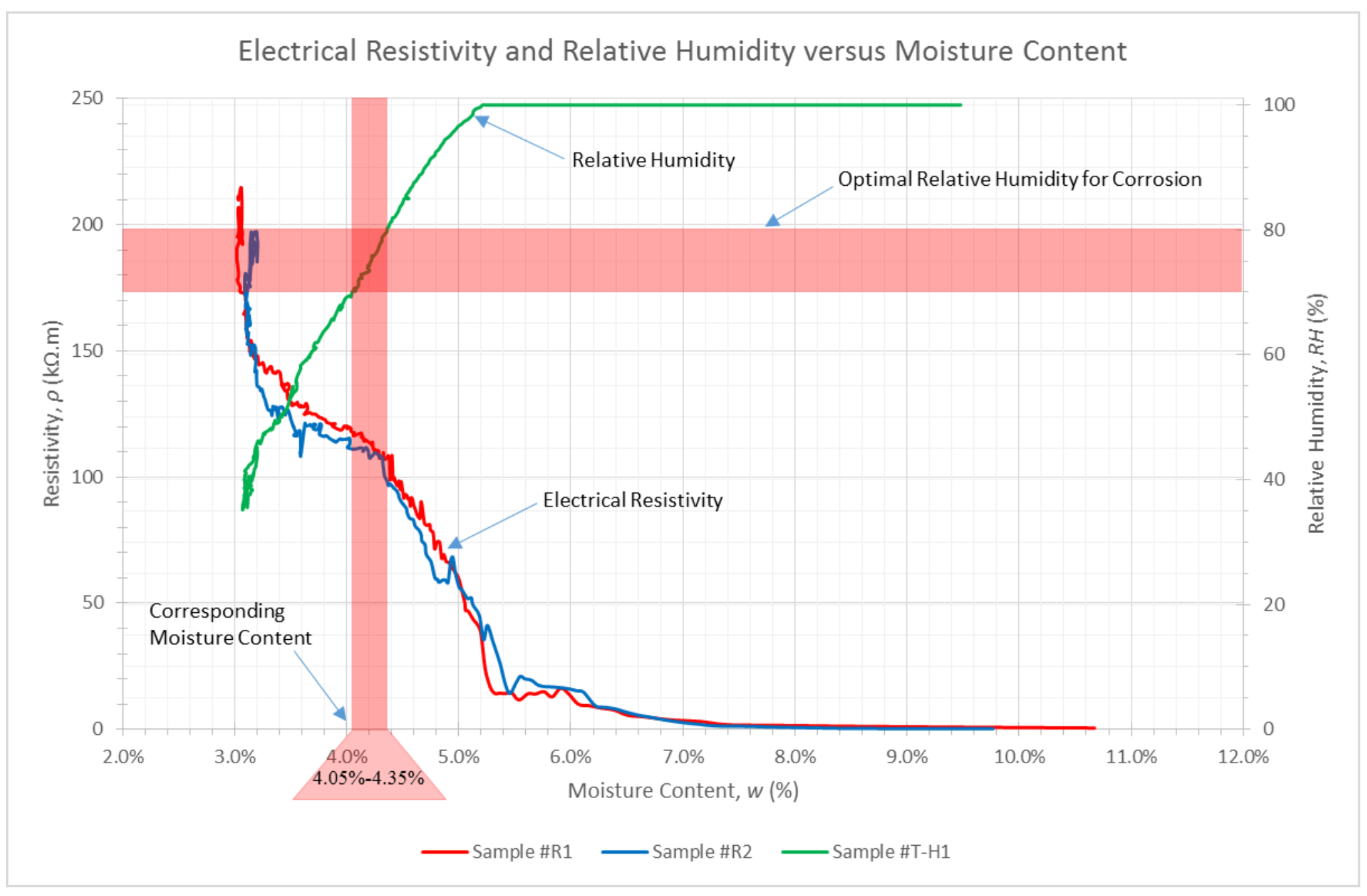

Figure 5-21 Calibration curve for corrosion data interpretation 


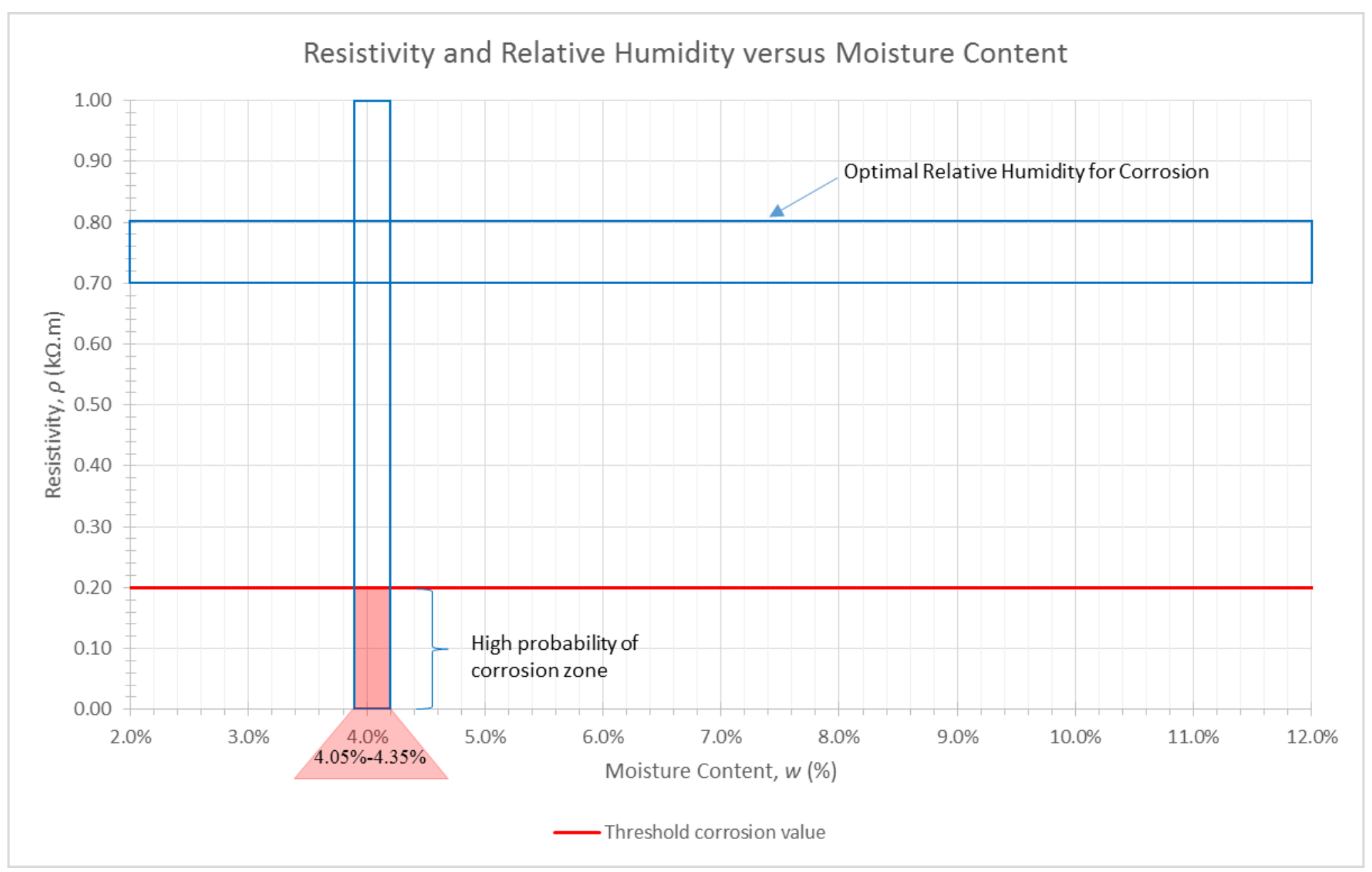

Figure 5-22 Calibration curve for corrosion data interpretation showing high potential for corrosion zone 


\subsection{CONCLUSIONS}

This chapter presented the details on the geometry and material used in designing the electrical resistivity sensor, together with the details about the temperature/humidity sensor. Laboratory experiments have been conducted and the data obtained have been used to develop a calibration curve for interpreting field data for assessing the potential for corrosion. The published literature indicates that corrosion activity is very likely in reinforced concrete structural members if the concrete resistivity is below $0.2 \mathrm{k} \Omega . \mathrm{m}$ and when the relative humidity within the concrete is between $70-80 \%$. Based on the experiments conducted in this study, the optimal relative humidity for corrosion was found to correspond to about $4 \%$ moisture content for the electrical resistivity sensors developed in this study. It should be noted that the electrical resistivity versus moisture content relationship developed in this chapter correspond to the use of tap water. This relationship will change in the field environment as salt infiltrates into the pore water in concrete. However, the key parameter affecting corrosion is the electrical resistivity of concrete, which is the parameter directly measured by the sensor developed here. 


\section{ChAPTER 6. FIELD APPLICATION/MONITORING}

\subsection{INTRODUCTION}

One of the objectives of this research was to use the designed electrical resistivity sensor and the commercially available temperature/humidity sensor to monitor the newly rehabilitated columns of USACE East Lynn Lake Bridge, West Virginia, for assessing the potential for further corrosion after the rehabilitation work. Six electrical resistivity sensors and eight temperature/humidity sensors were installed during the rehabilitation work. Details about the installation of the sensors and data collected on the bridge are presented in subsequent sections in this chapter.

\subsection{OVERVIEW OF EAST LYNN LAKE BRIDGE}

East Lynn Lake Bridge was designed in 1969 and constructed during 1971-72. The bridge is 126.5 feet long and comprises of 2 lanes, 5 spans of continuous reinforced concrete slab supported by steel H-piles and abutments. Pictures of the bridge prior to the rehabilitation work are shown in Figure 6-1. The portion of the steel H-piles above the permanent water level got corroded over time due to seasonal rise and fall in the water levels, resulting in section loss of the steel up to 50\% (Figure 6-2). The capacity of the bridge was thus reduced, resulting in load rating of 6 tons (the original rating was around 15 tons), with one lane closure and maximum speed reduced to $10 \mathrm{mph}$ (Liang et al. 2014).

The portion of the H-piles above the fluctuating water level was free of corrosion damage as shown in Figure 6-1. This can be attributed to the fact that even though that portion of the H-pile may have gotten wet, the moisture was not enough to cause corrosion. In addition, that portion of the pile can act as the cathode for corrosion reactions and hence not suffer corrosion damage. 


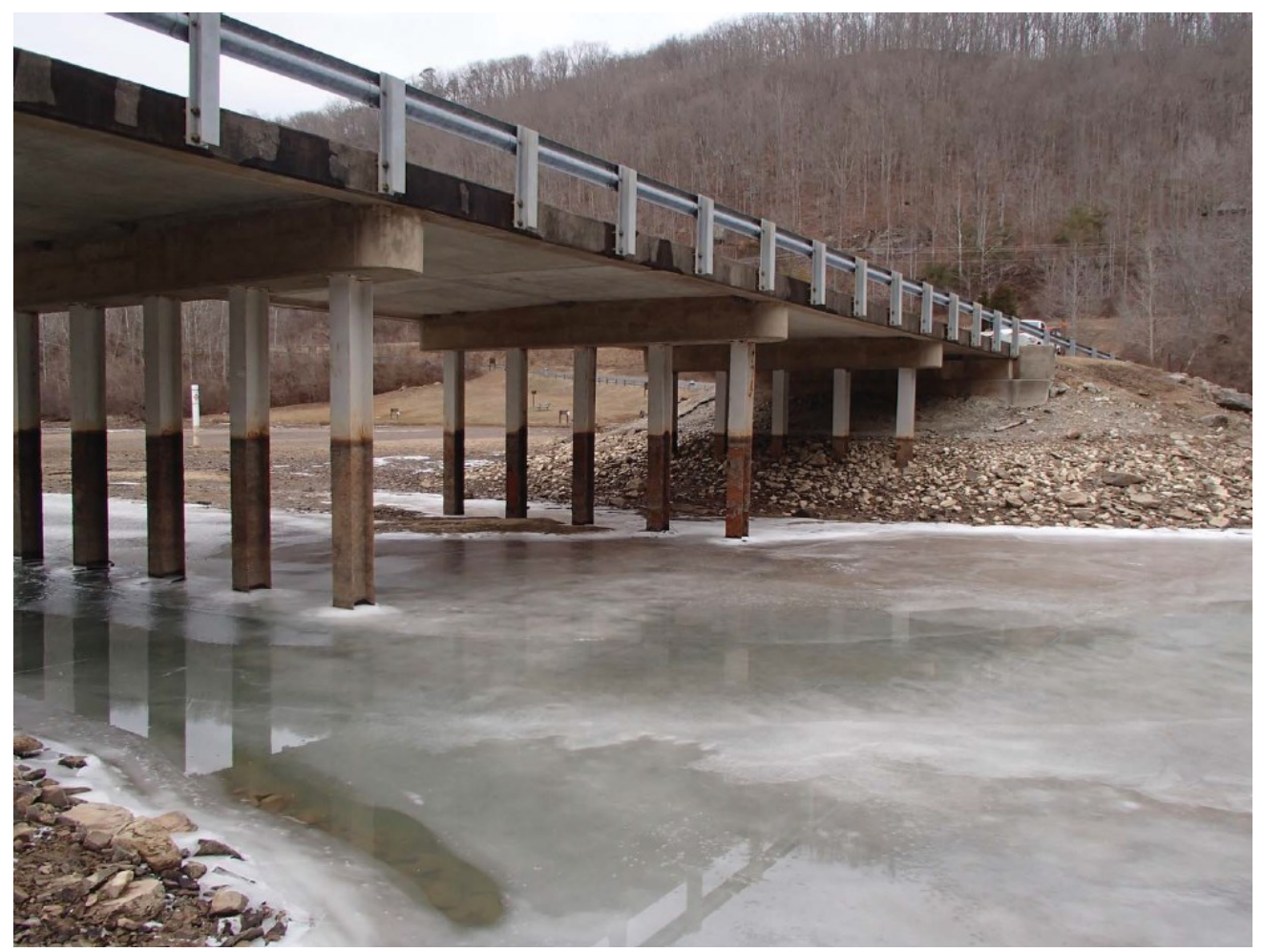

(a)

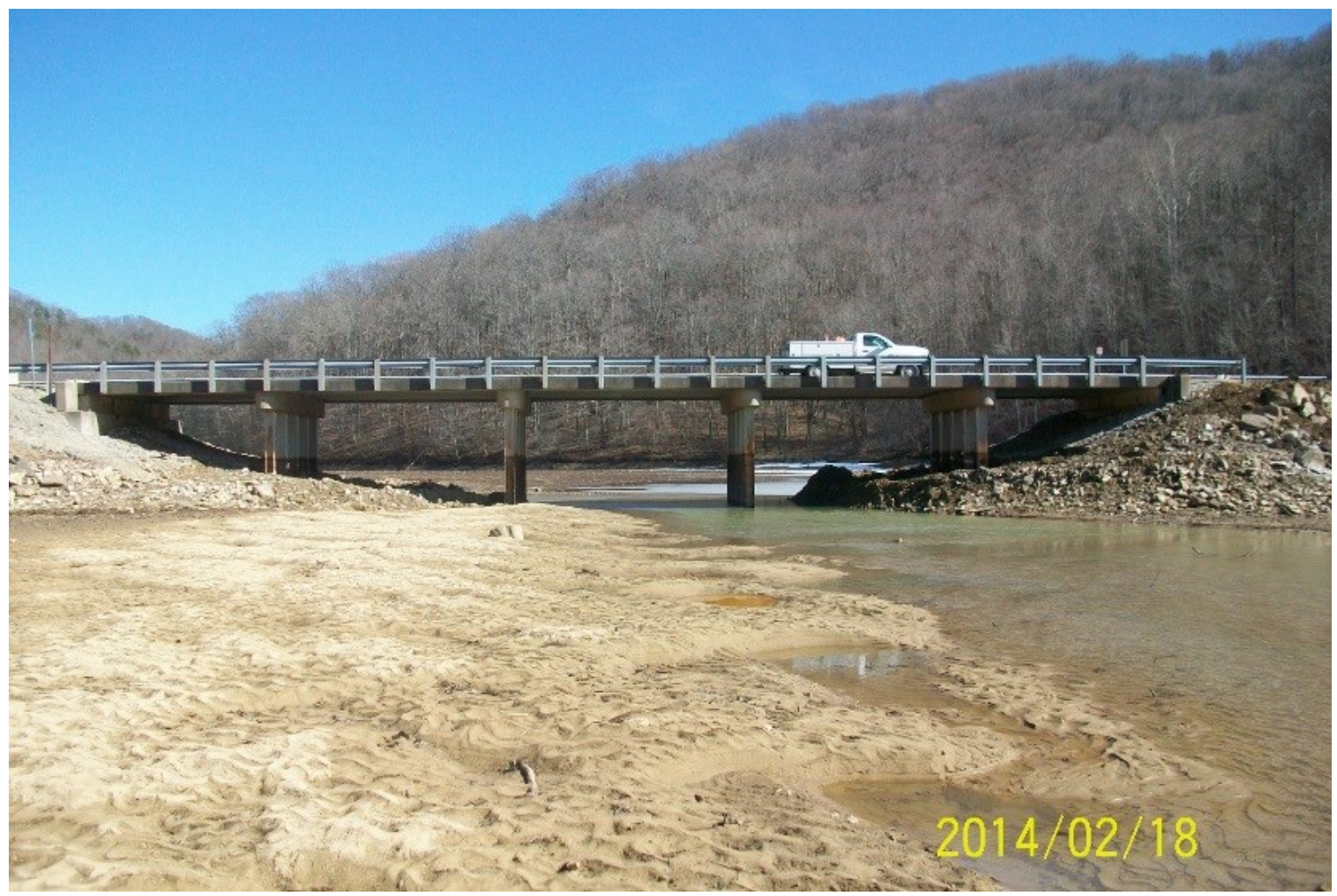

(b)

Figure 6-1 (a) and (b) East Lynn Lake Bridge before rehabilitation (USACE 2014) 

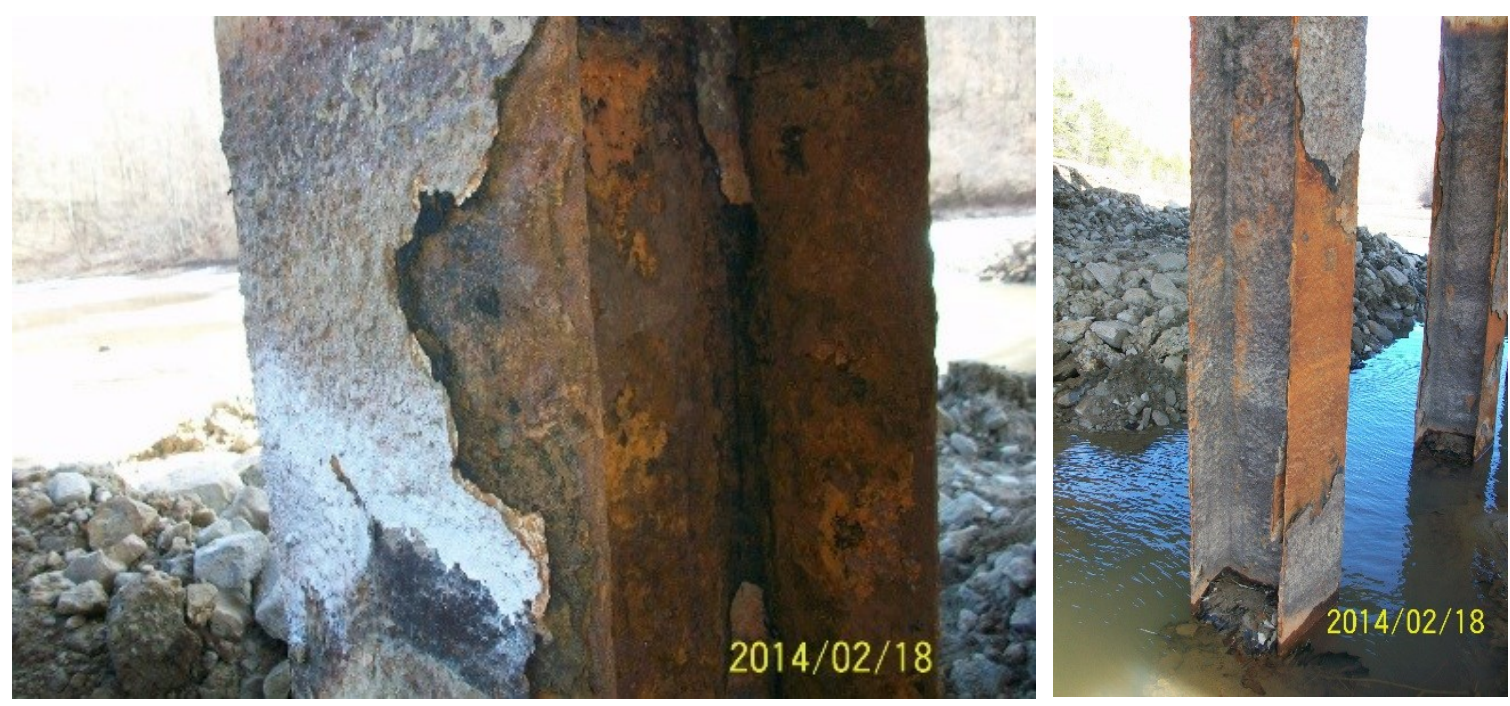

Figure 6-2 Close-up view of corroded H-piles

The portion of the piles about 1 foot below the ground surface was however sound and free from corrosion (Figure 6-3). This was observed after 3 feet deep trenches were dug around the piles to expose the portion beneath the ground surface. This portion of the piles did not corrode because it was permanently submerged under water and there was no oxygen available to promote corrosion reaction.
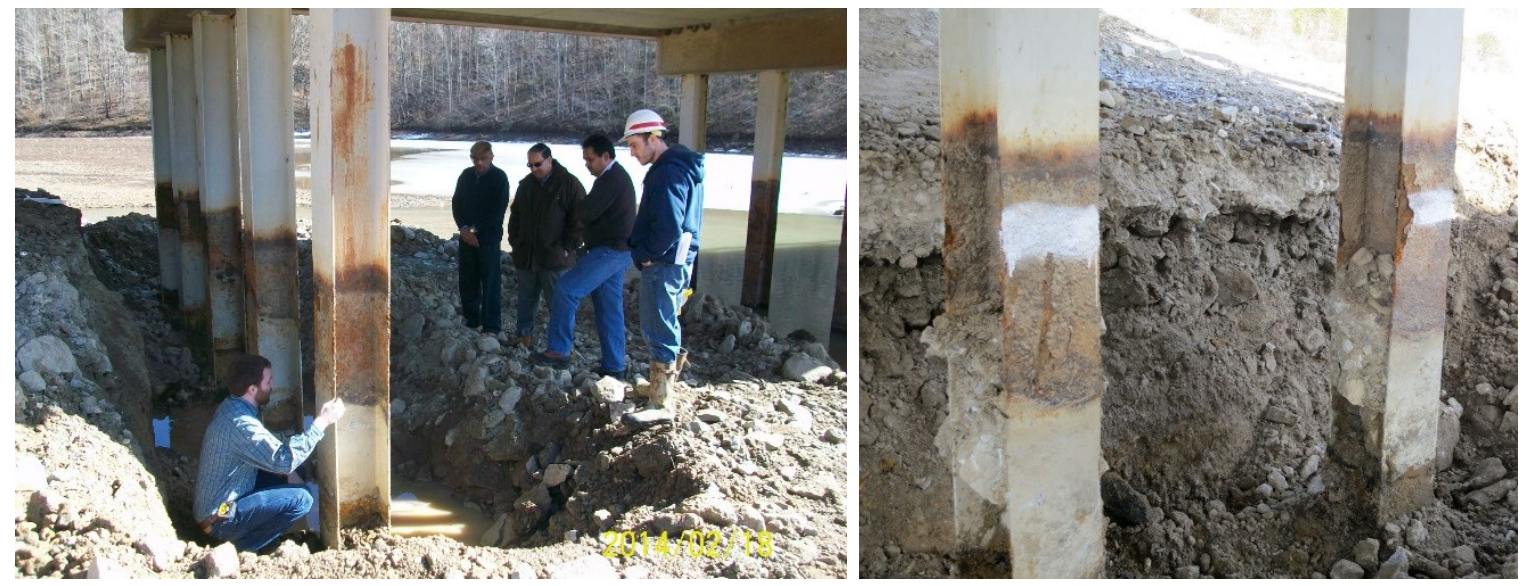

Figure 6-3 Submerged portion of piles free from corrosion damage 


\subsection{BRIDGE REHABILITATION AND INSTALLATION OF SENSORS}

The bridge was rehabilitated by faculty, staff and students from the Constructed Facilities Center at West Virginia University (Liang et al. 2014), along with personnel from the U.S. Army Corps of Engineers (USACE). The rehabilitation was carried out using selfconsolidated concrete (SCC) wrapped with advanced FRP composite materials to bring it back to the original design capacity. During the rehabilitation process, polymer concrete was used as a foundation barrier, which also took the load of the SCC above it. The load from the rehabilitated columns was transmitted back to the portion of the steel H-piles below the ground which did not have any corrosion. This load transmission was aided by the use of metallic shear studs in the steel H-piles within the polymer concrete. The FRP jackets/shells (Figure 6-4) served as formwork and also enhanced the load carrying capacity of the rehabilitated columns by providing confinement. The polymer concrete also serves to prevent the lake water from getting to the concrete above it after the rehabilitation.
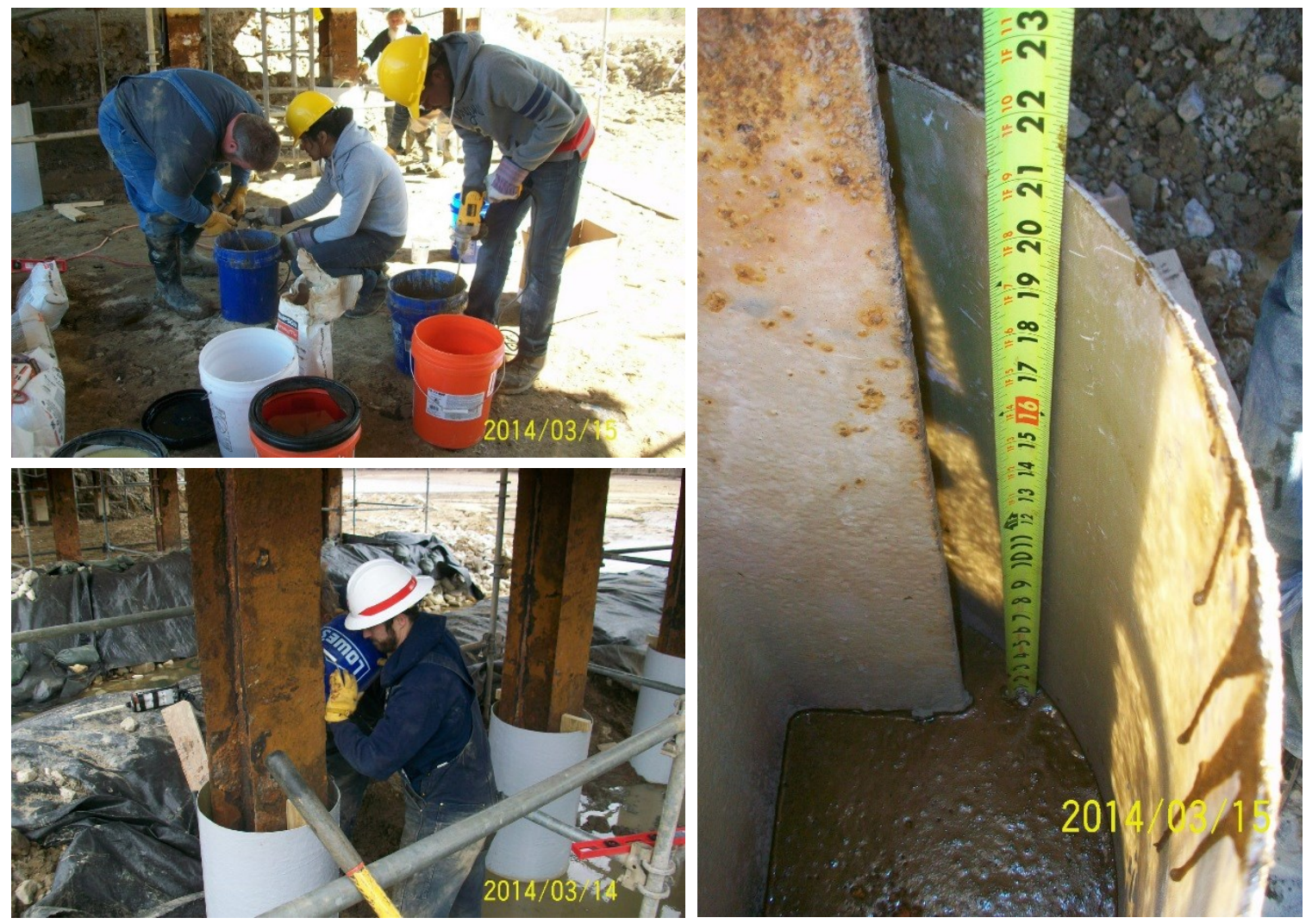

Figure 6-4 Polymer concrete foundation barrier 
The steel piles were enclosed in 20" diameter glass fiber reinforced polymer (GFRP) composite shells. The GFRP shells surrounding the steel H-piles were then wrapped with two layers of GFRP fabric and filled with self-consolidated concrete. The self-consolidated concrete had a 28 days strength of $21 \mathrm{MPa}$ (3050psi, average of 3 cylinders) (Liang et al. 2014). Finally, UV protective coating was applied to the surface of the completed columns (surface of GFRP wraps). The GFRP wrap also provided a water-tight seal, preventing the lake water from entering the rehabilitated piles.

Before the FRP shells were installed, six electrical resistivity sensors and six temperature/humidity sensors were attached to the surface of the steel piles (in the corroded portion) to enable nondestructive monitoring of further corrosion potential after rehabilitation. In addition, two temperature/humidity sensors were placed outside in a location under the bridge to measure the ambient temperature/humidity. The sensors were wired and connected to a central monitoring board, which can house a data acquisition unit if needed. The rehabilitation process is summarized in Figures 6-5 through 6-10.
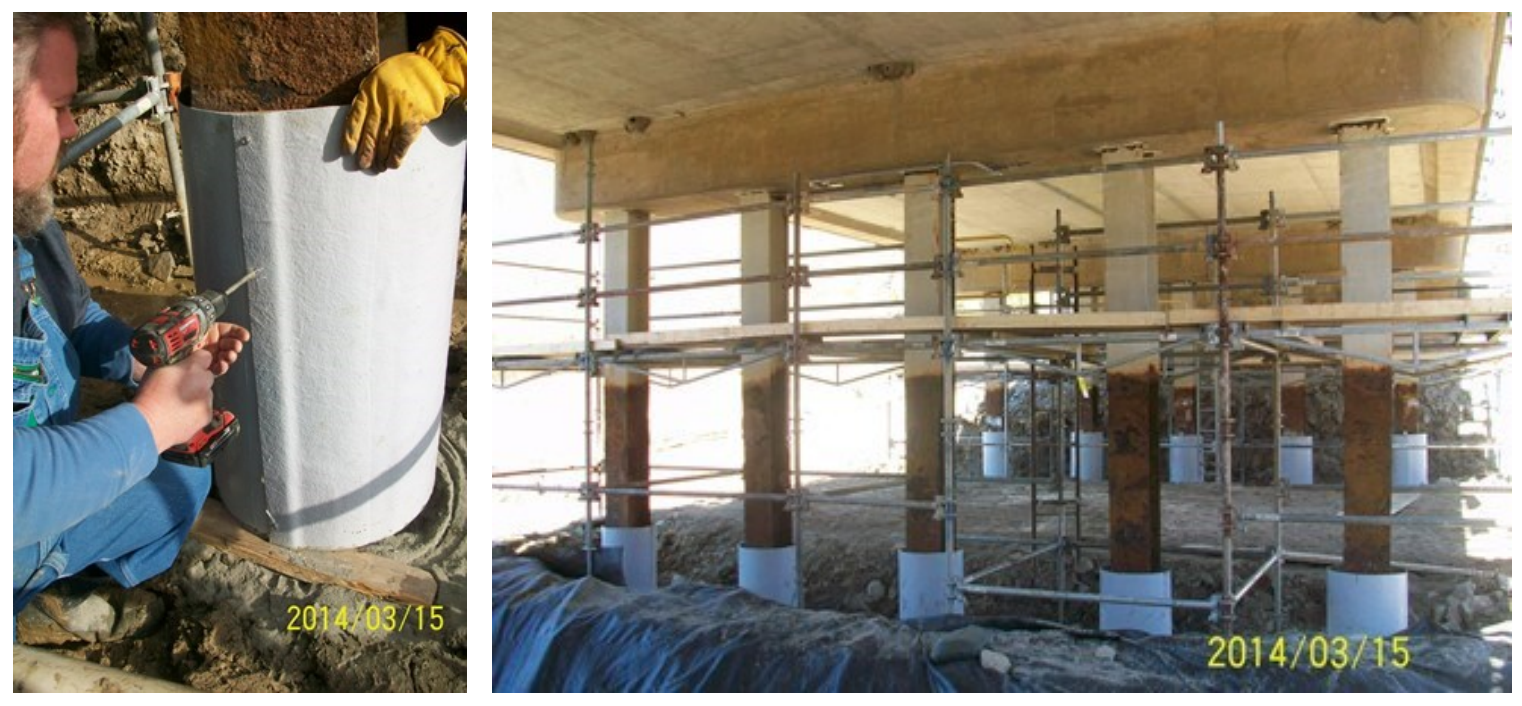

Figure 6-5 Installation of bottom GFRP shells 


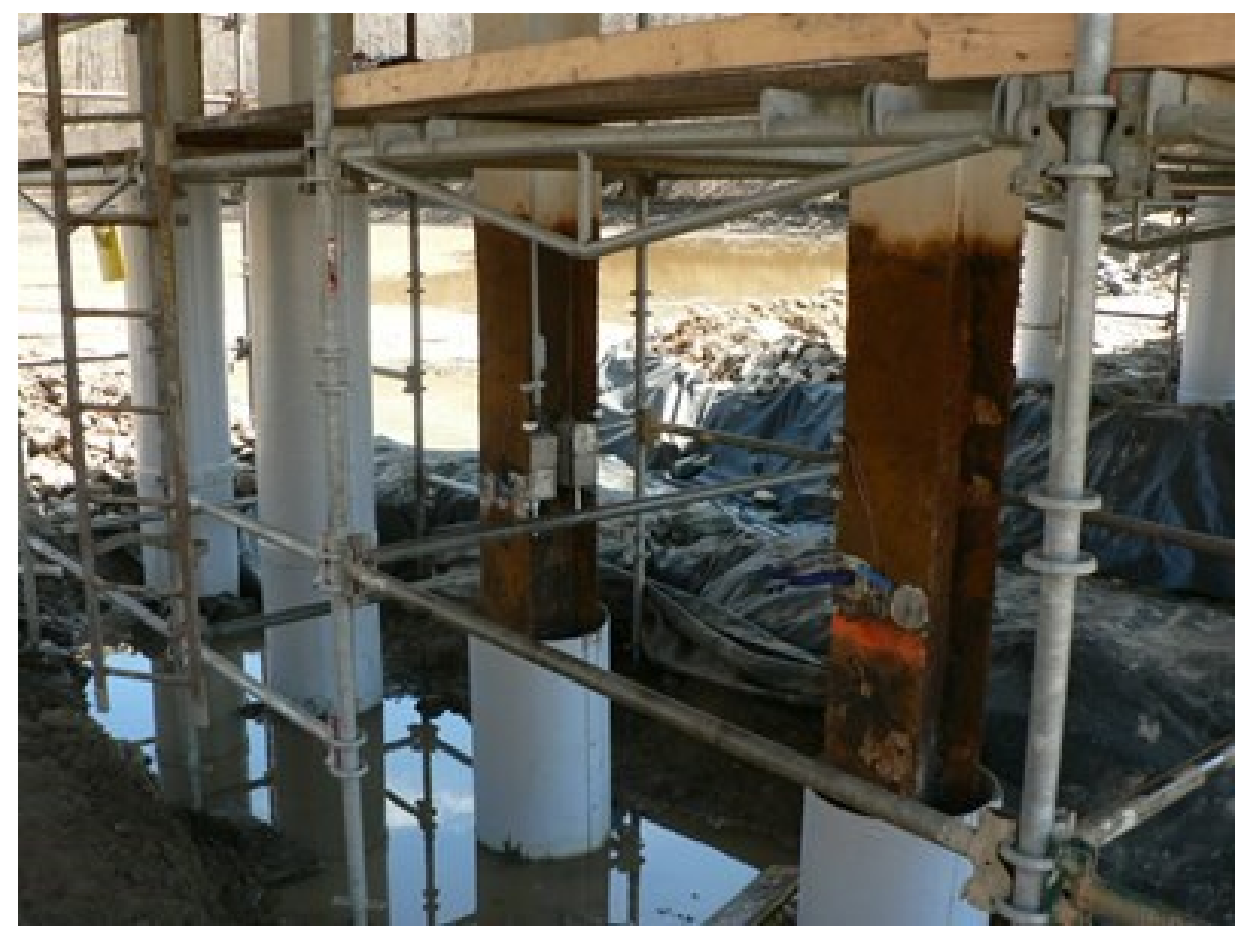

(a)

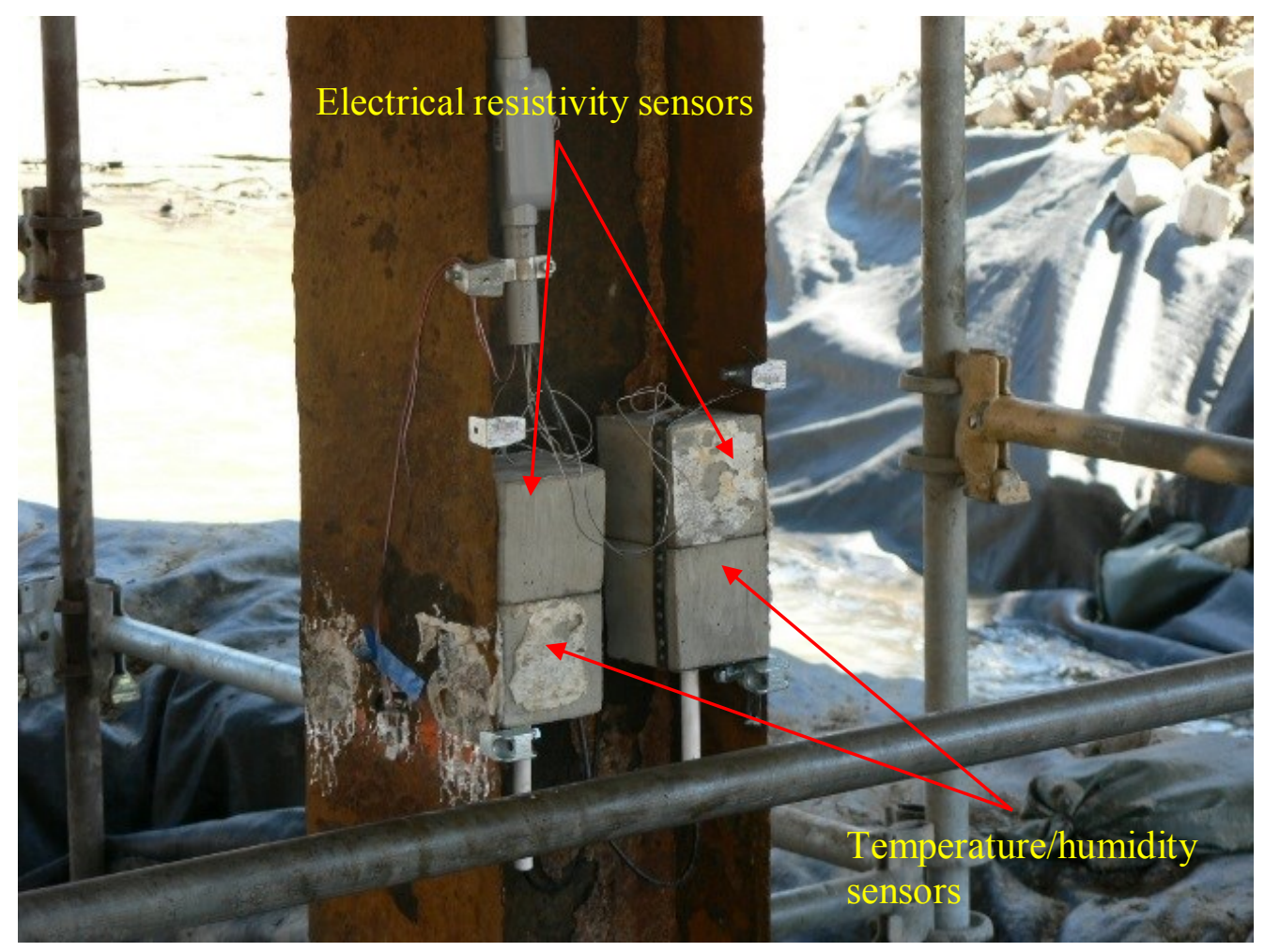

(b)

Figure 6-6 (a) and (b) Resistivity and temperature/humidity sensors installed in East Lynne Bridge columns 

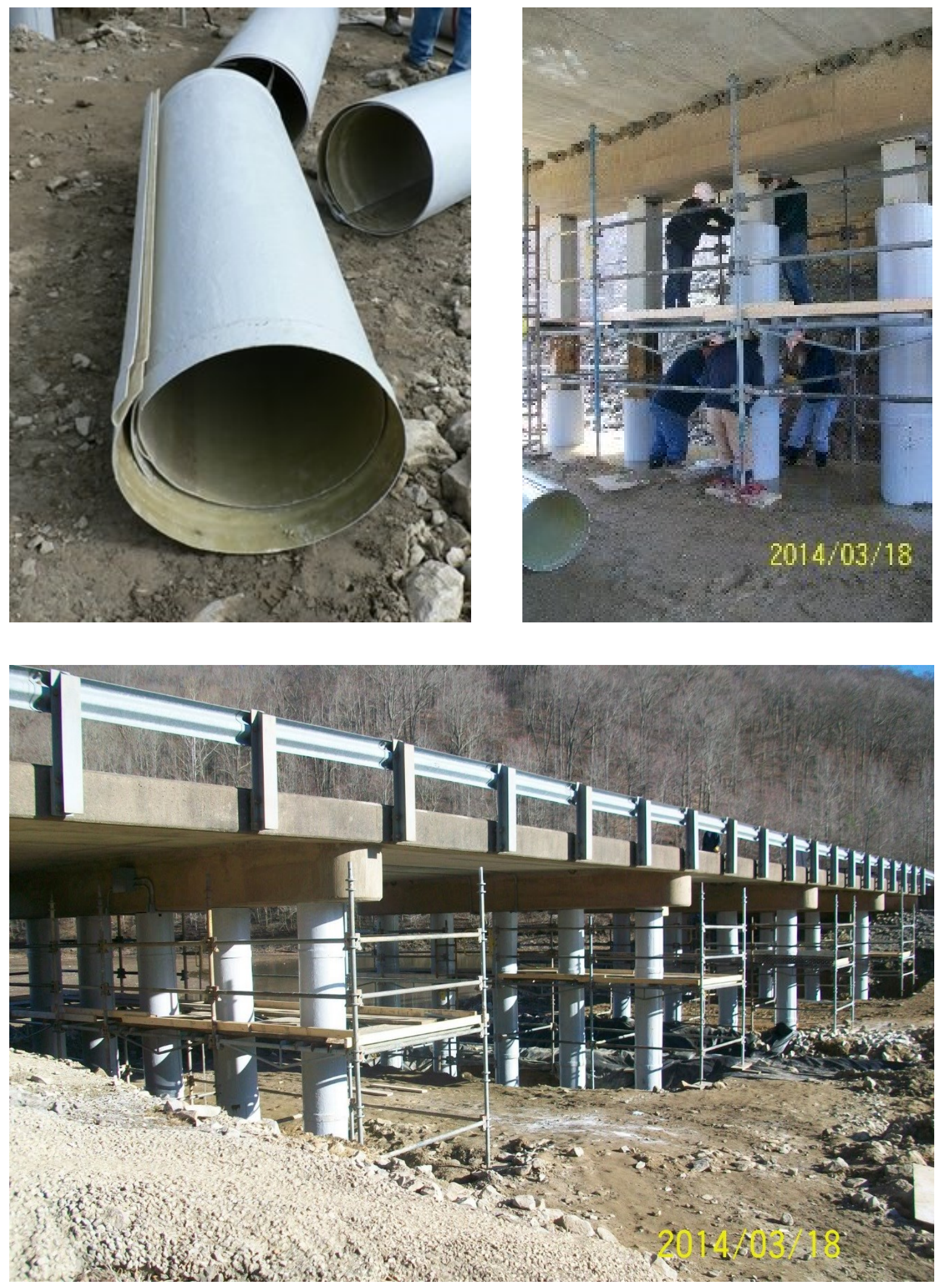

Figure 6-7 Installation of upper FRP shells 

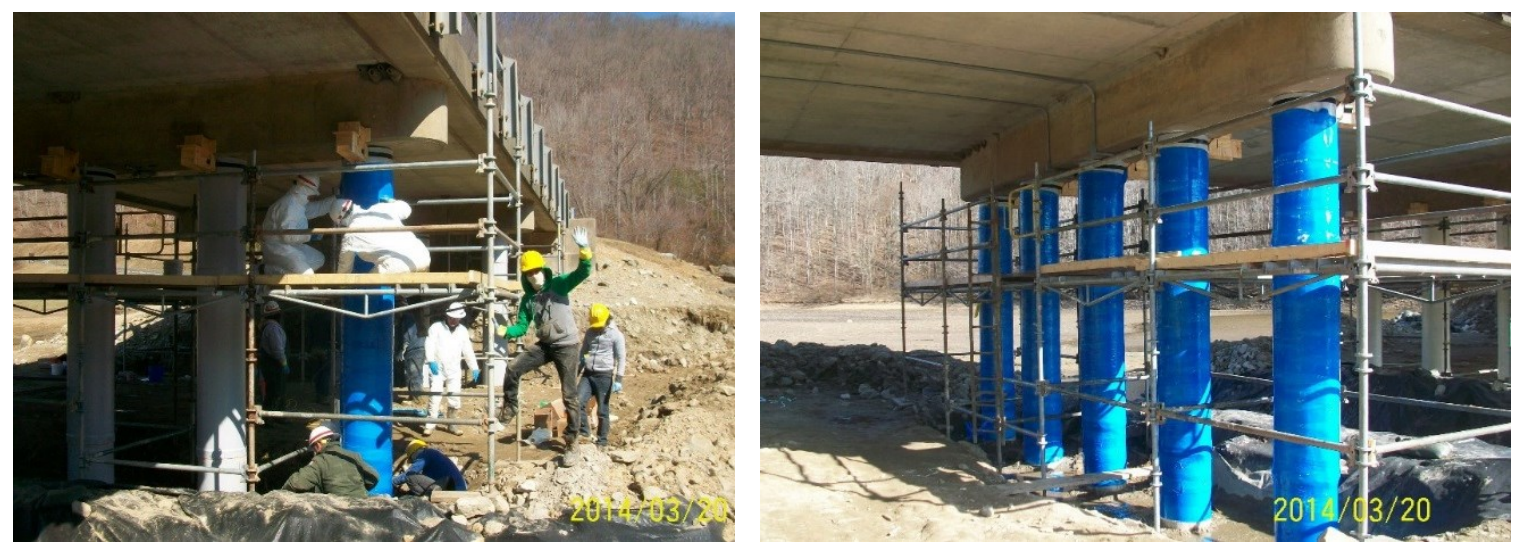

Figure 6-8 Piles being wrapped with GFRP fabric
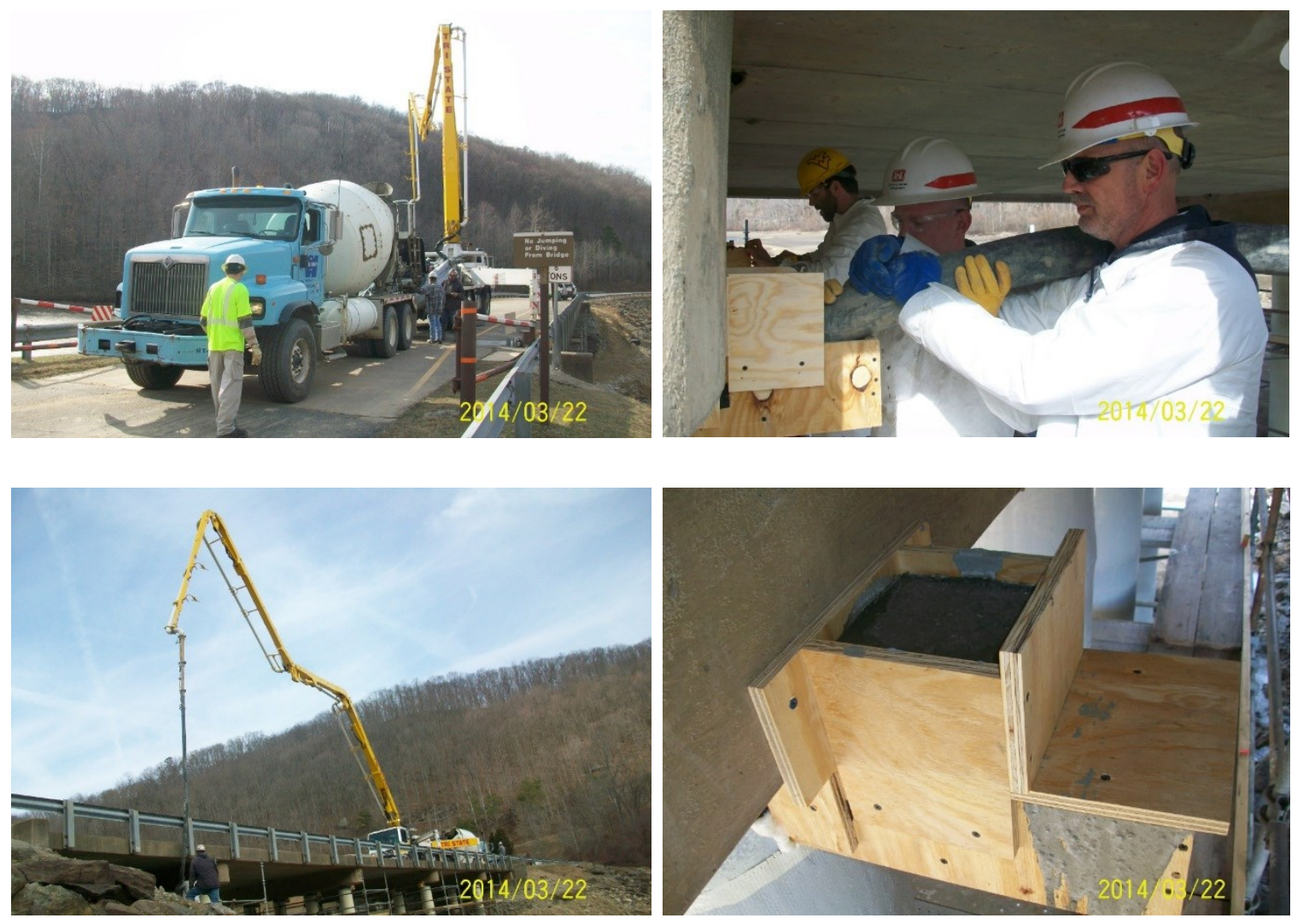

Figure 6-9 Pouring self-consolidated concrete 


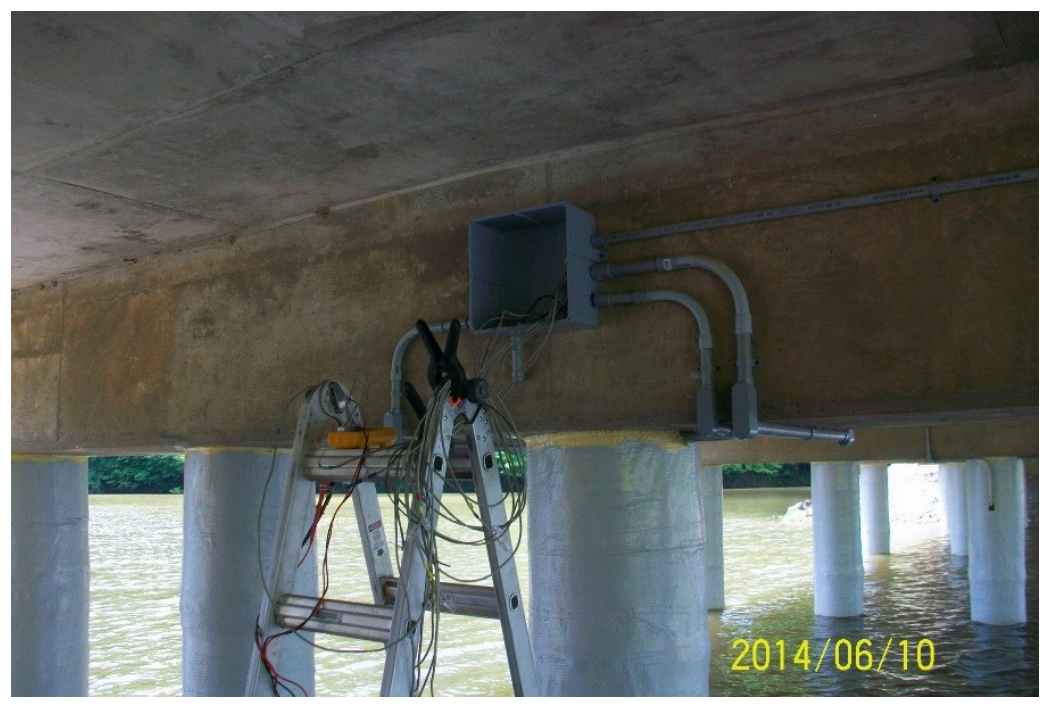

Figure 6-10 Central monitoring board for data collection

The rehabilitation of the 20 piles (columns) of the bridge was completed in 3 weeks during March 2014, which brought the bridge back to the original design capacity at $25 \%$ of conventional construction cost for the bridge (Liang et al. 2014). Figure 6-11 shows the bridge after rehabilitation.

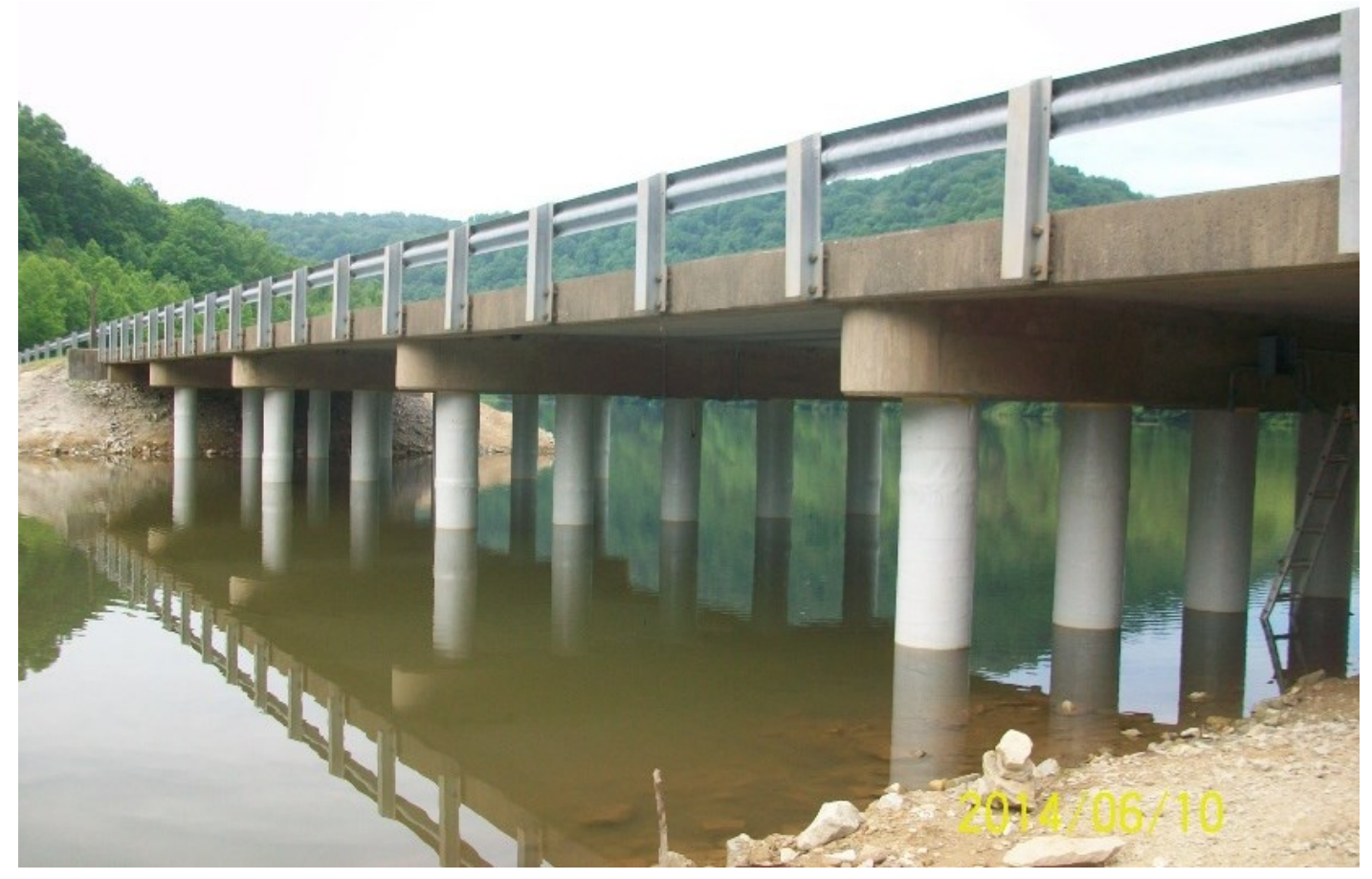

Figure 6-11 East Lynn Lake Bridge after rehabilitation 


\subsection{Field DATA COLLECTION AND INTERPRETATION}

After rehabilitation, electrical resistivity and temperature/humidity data was collected on the bridge piles (columns) to monitor them for further corrosion. The designation used in grouping the bridge piles for identification purpose is shown in Figure 6-12.

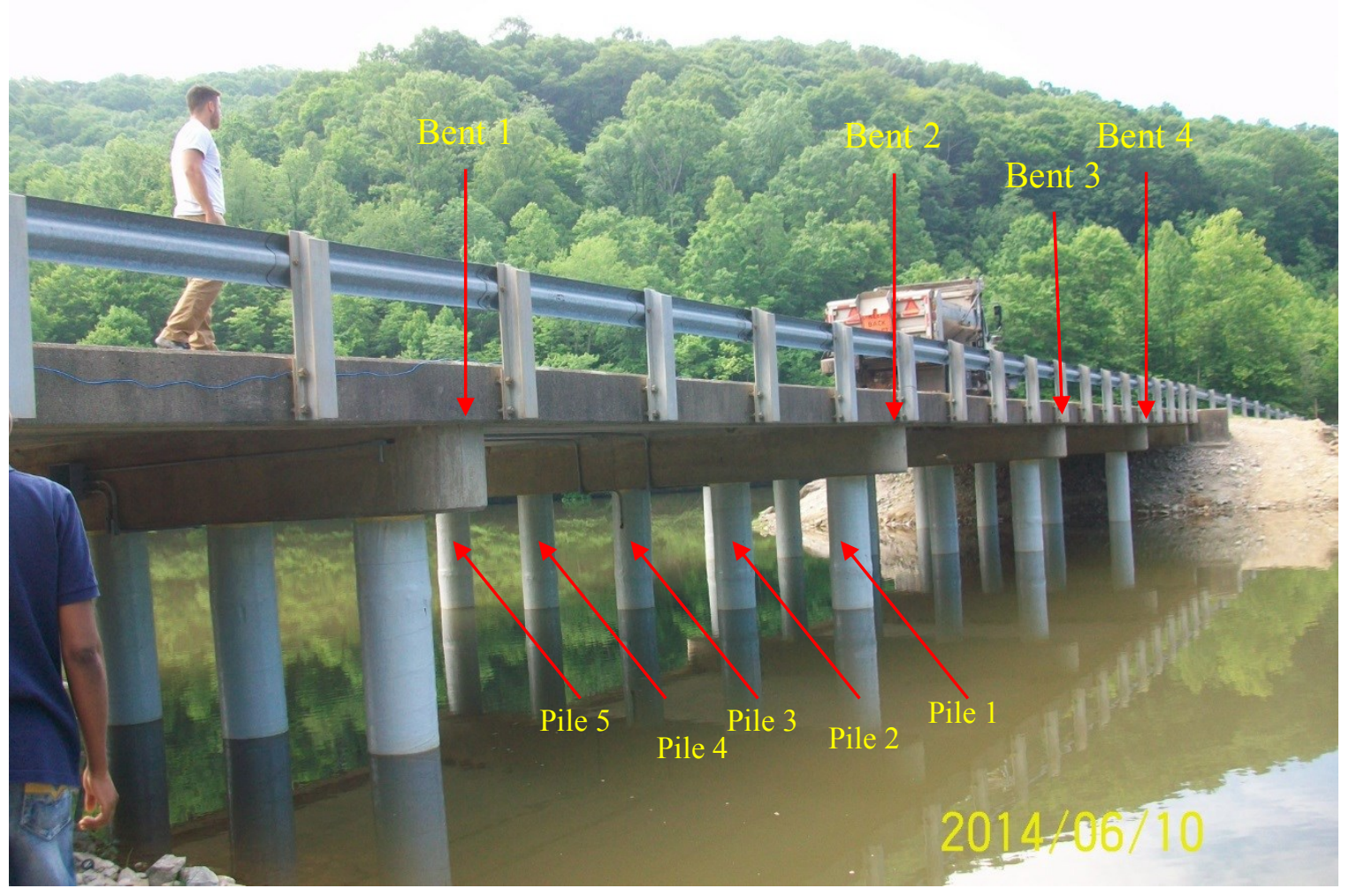

Figure 6-12 East Lynn Lake Bridge pile identification plan

The sensors were installed in three of the piles (Pile 3 in Bent 1, and Piles 3 and 4 in Bent 2). The three piles had two sensors of each type (electrical resistivity, and temperature/humidity), placed in the corroded portion. In addition, two temperature/humidity sensors were placed outside in a location under the bridge to measure the ambient temperature/humidity. As mentioned earlier, the sensors were wired to a central monitoring board installed just under the bridge (this location is usually above the water level). 
Two field trips were made to collect data from the embedded sensors in the bridge during a six months interval. Table 6-1 presents the data obtained during these trips. Equation 56 was used in computing the resistivity values in Table 6-1. Temperature/humidity sensors within the piles recorded humidity values higher than $100 \%$. This means the pores of the concrete is saturated, hence those values are presented as $99.99 \%$ in Table 6-1.

The high humidity data (for temperature/humidity sensors 1 through 6) in Table 6-1 means the concrete is saturated and the potential for corrosion is very low since no oxygen will be available within the concrete to promote corrosion. The high humidity within the concrete also means there will be no shrinkage cracks developed in the concrete. It should be noted that the high humidity recorded is not due to moisture ingress from the lake. This humidity resulted from the excess water after curing of the self-consolidated concrete that is trapped within the concrete pile by the polymer concrete foundation barrier and the GFRP shell and wraps surrounding the piles.

Relative humidity outside the piles was found to be between $72.67 \%$ and $83.40 \%$ for the two data sets collected, which indicates that the environment is moist during both summer and winter months.

Electrical resistivity values of the piles, presented in Table 6-1, were found to be higher than the $0.2 \mathrm{k} \Omega . \mathrm{m}$ threshold value even though the concrete is saturated. This high value means movement of ions through the concrete will be restricted, thereby preventing corrosion. This further emphasizes the point made earlier that the potential for corrosion of the encased steel H-piles is very low. 
Table 6-1 Field data for East Lynn Lake Bridge

Electrical Resistivity measurement

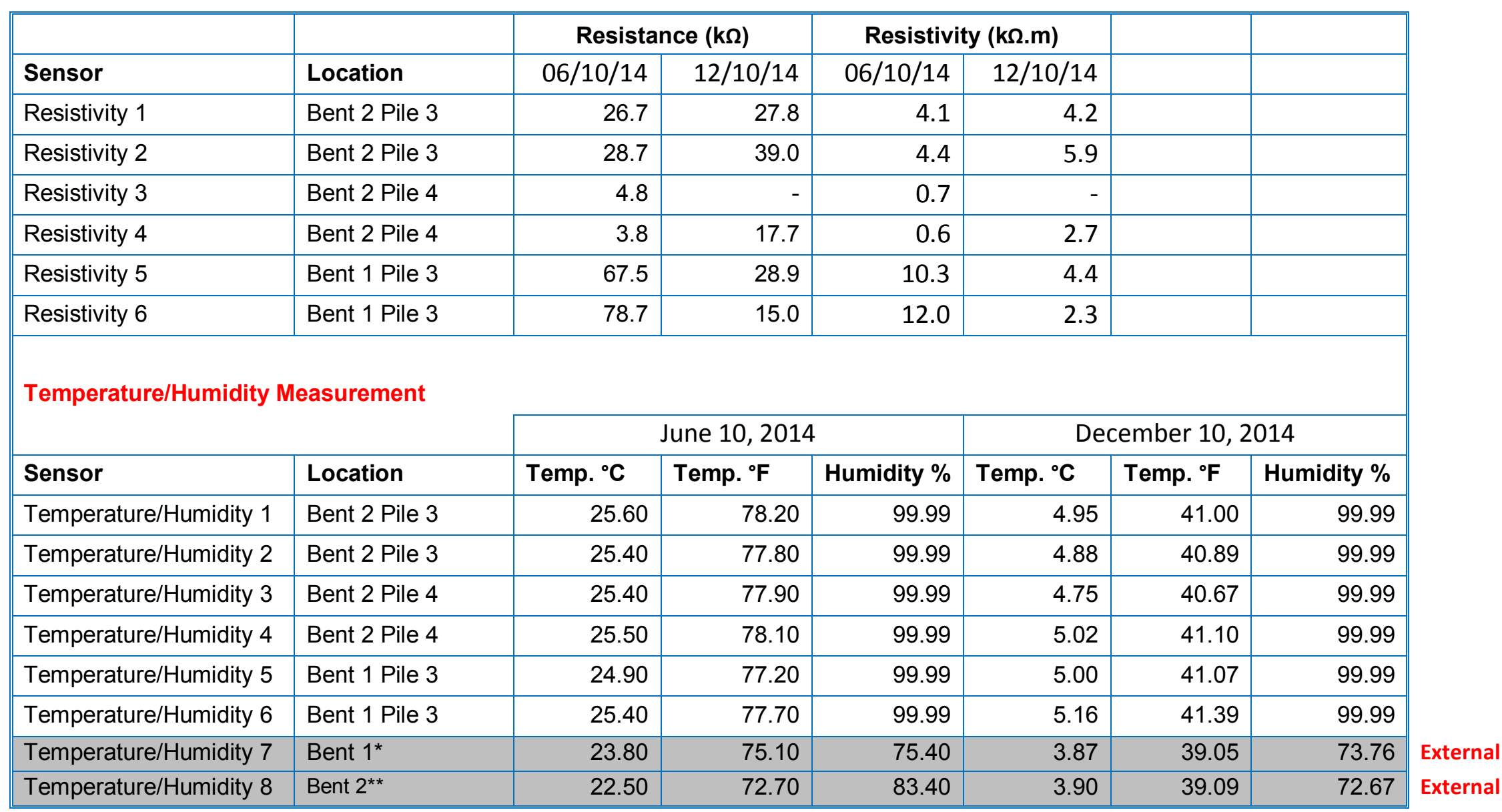

External External sensors, located outside the piles

* Sensor located at edge of Bent 1

** Sensor located at center of Bent 2 


\subsection{CONCLUSIONS}

The data obtained from field monitoring of East Lynn Lake Bridge shows the suitability of the newly designed electrical resistivity sensor and the commercially available temperature/humidity sensor for monitoring the potential for corrosion in reinforced concrete structures. It also shows these sensors can be used in monitoring buried and submerged structures, as well as reinforced concrete structures wrapped with FRP shells and/or fabric wraps. The sensors also show that the polymer concrete foundation barrier, and the GFRP shell and wraps make the piles water tight, protecting them from the surrounding lake water, and significantly reducing the potential for corrosion of the encased steel H-piles. 


\section{ChAPTER 7. CONCLUSIONS AND RECOMMENDATIONS}

\subsection{RESEARCH SUMMARY}

The objectives of this research were to develop low cost and durable sensors for monitoring corrosion of steel encased in concrete through electrical resistivity measurement, and to use the sensors together with commercially available temperature/humidity senor to monitor steel encased inside FRP wrapped concrete members for potential corrosion after rehabilitation works. These were achieved by performing the following tasks:

- A low cost and durable concrete electrical resistivity sensor was developed using steel plates encased in concrete.

- Laboratory test was conducted on the sensors to develop detailed calibration curve for field data interpretation using the electrical resistivity sensor and a commercially available temperature/humidity sensor.

- A number of sensors were installed during the rehabilitation work for USACE East Lynn Lake Bridge in West Virginia, and is currently being used to monitor the bridge for potential of further corrosion of the steel component encased in FRP wrapped concrete columns.

\subsection{CONCLuSIONS}

A low cost and durable corrosion monitoring technique has been developed in this research using electrical resistivity and temperature/humidity measurements. The following conclusions can be made from the findings of this research:

- The literature review has shown that corrosion of steel in concrete is most likely to occur if the concrete resistivity is less than $0.2 \mathrm{k} \Omega . \mathrm{m}$ and when the humidity within the concrete is between $70-80 \%$ (which corresponds to moisture content around $4 \%$ for the electrical resistivity sensors developed in this study).

- For concrete resistivity below $0.2 \mathrm{k} \Omega . \mathrm{m}$, if the humidity within the concrete is higher than $80 \%$, corrosion is less likely since the concrete becomes close to saturation at that humidity level and no oxygen will be available to promote corrosion. 
- Higher resistivity of concrete limits the flow of ions through the concrete, thereby making it less likely for corrosion to occur.

- As humidity within the concrete gets below $70 \%$, corrosion of steel becomes less likely since there will be not enough moisture to promote reduction reactions and ionic transport.

- The electrical resistivity and temperature/humidity sensors investigated in this research offer a low cost system for field monitoring of potential for corrosion of steel encased in concrete structural members, with or without FRP wraps.

\subsection{RECOMMENDATIONS FOR FUTURE STUDIES}

The following tasks are recommended for future works and/or expansion to this research.

- Data should be collected at regular intervals to help determine the corrosion condition of the structure over time.

- An automated data acquisition unit should be installed in the field to enable data collection at regular intervals with ease. Where cellular network is available, data acquisition unit should be equipped with cellular modem to enable remote data collection on the structure. 


\section{REFERENCES}

Abu Yosef, A. E., Pasupathy, P., Wood, S. L., \& Neikirk, D. (2012a). Low-Cost Threshold Sensors for Corrosion Detection in Bridge Decks. NDE/NDT for Highways and Bridges: Structural Materials Technology (SMT) (pp. 2-7). New York: The American Society for Nondestructive Testing, Inc.

Abu-Yosef, A. E., Pasupathy, P., Wood, S. L., \& Neikirk, D. P. (2012b). Detection of Multiple Corrosion Thresholds in Reinforced Concrete Structures using Passive Sensors. Proc. of SPIE Vol. 8347. San Diego, CA.

Andrade, C., \& Alonso, C. (1996). Corrosion Rate Monitoring in the Laboratory and Onsite. Construction and Building Materials, 10(5), 315-328.

Angst, U., \& Vennesland, Ø. (2009). Critical Chloride Content in Reinforced Concrete State of the art. In M. G. Alexander, H.-D. Beushausen, F. Dehn, \& P. Moyo (Eds.), Concrete Repair, Rehabilitation and Retrofitting II. London: Taylor \& Francis Group.

ASTM C 876-09. (2009). Standard Test Method for Corrosion Potentials of Uncoated Reinforcing Steel in Concrete. West Conshohocken, PA: ASTM International. Retrieved May 29, 2014

ASTM G 102-89. (1989). Standard Practice for Calculation of Corrosion Rates and Related Information. West Conshohocken, PA: ASTM International. Retrieved 01 $15,2015$.

ASTM G 59-97. (1997). Standard Test Method for Conducting Potentiodynamic Polarization Resistance Measurements. West Conshohocken, PA: ASTM International. Retrieved January 12, 2015.

Bastidas-Arteaga, E., \& Stewart, M. G. (2013). Probabilistic Cost-Benefit Analysis of Climate Change Adaptation Strategies for New RC Structures exposed to chloride ingress. In G. Deodatis, B. R. Ellingwood, \& D. M. Frangopol (Ed.), Safety, 
Reliability, Risk and Life-Cycle Performance of Structures and Infrastructures (pp. 1503-1510). London: CRC Press/Balkema.

Broomfield, J. (1997). Corrosion of Steel in Concrete: Understanding, Investigation and Repair. UK: E \& FN Spon.

Broomfield, J. P. (2007). Corrosion of Steel in Concrete: Understanding, Investigation and Repair. New York: Taylor and Francis.

Broomfield, J. P., Rodriguez, J., Ortega, L. M., \& Garcia, A. M. (1993). Corrosion Rate Measurements in Reinforced Concrete Structures by a Linear Polarization Device. Proceedings of the International Symposium on Condition assessment, Protection, Repair, and Rehabilitation of Concrete Bridges Exposed to Aggressive Environments, ACI Fall Convention. 9th-10th November. Minneapolis, MN.

Bungey, J. H. (1989). Testing of Concrete in Structures (2nd ed.). New York: Chapman \& Hall.

Carino, N. J. (2004). Methods to Evaluate Corrosion of Reinforcement. In V. M. Malhotra, \& N. J. Carino (Eds.), Handbook on Nondestructive Testing of Concrete (2nd ed.). Boca Raton, London, New York, Washington D.C.: CRC Press.

Chávez-Ulloa, E., Camacho-Chab, R., Sosa-Baz, M., Castro-Borges, P., \& Pérez-López, T. (2013). Corrosion Process of Reinforced Concrete by Carbonation in a Natural Environment and an Accelerated Test Chamber. International Journal of Electrochemical Science, 8, 9015-9029.

Clear, K. C. (1989). Measuring Rate of Corrosion of Steel in Field Concrete Structures. Transportation Research Record, Record No. 1211, 28-37.

Das, B. M. (2010). Principles of Geotechnical Engineering (7th ed.). Stanford, CT: Cengage Learning.

Davis, J. R. (2000). Corrosion: Understanding the Basics. Ohio: ASM International.

Dean, S. W. Jr., France, W. D. Jr., \& Ketcham, S. J. (1971). Electrochemical Methods. (W. H. Ailor, Ed.) Handbook on Corrosion Testing and Evaluation, 173-174. 
Feliú, A., González, J. A., \& Andrade, C. (1996). Electrochemical Methods for On-site Determinations of Corrosion Rates of Rebars. In N. S. Berke, E. Escalante, C. Nmai, \& D. Whiting (Eds.), Techniques to Assess the Corrosion Activity of Steel Reinforced Concrete Structures (Vol. ASTM STP 1276). West Conshohocken, PA: ASTM.

GangaRao, H. V. S., Taly, N., \& Vijay, P. V. (2007). Reinforced Concrete Design with FPP Composites. London: CRC Press.

Gucunski, N., Feldmann, R., Romero, F., Kruschwitz, S., Hawash, A. A., \& Dunn, M. (2009). Multimodal Condition Assessment of Bridge Decks by NDE and Its Validation. Proceedings of the 2009 Mid-Continent Transportation Research Symposium, August 2009. Ames, Iowa.

Halabe, U. B., GangaRao, H. V. S., \& Nagavardhana, P. (2012). Infrared Thermography and GPR Techniques for Condition Assessment of RC Bridges. NDT/NDE for Highways and Bridges SMT, (pp. 120-127). New York, August 21-24.

James Instruments Inc. (2002). The GECOR8 Corrosion Rate Meter Instruction Manual. Second Edition.

Lambert, P., Page, C. L., \& Vassie, P. R. W. (1991). Investigation of Reinforcement Corrosion. 2. Electrochemical Monitoring of Steel in Chloride-contaminated Concrete. Materials and Structures, 24(143), 351-358.

Li, C. Q., Melchers, R. E., \& Zheng, J. J. (2006). An analytical Model for Corrosioninduced Crack Width in Reinforced Concrete Structures. ACI Structural Journal, 103(4), 479-487.

Li, Z., Leung, C., \& Xi, Y. (2009). Structural Renovation in Concrete. New York: Taylor \& Francis.

Liang, R., Skidmore, M., \& GangaRao, H. (2014). Rehabilitation of East Lynn Lake Bridge Steel Pile Bents with Composites. TRB Innovative Technologies for a Resilient Marine Transportation System 3rd Biennial Research and Development Conference, June 24-26, 2014. Washington, DC. 
Mallick, P. K. (2007). Fiber-Reinforced Composites: Materials, Manufacturing and Design (3rd Edition ed.). London: CRC Press.

Manning, D. G. (1995). Detecting Defects and Deterioration in Highway Structures. National Cooperative Highway Research Program Synthesis of Highway Practice 118.

McDonald, D. B., Pfeifer, D. W., \& Sherman, M. R. (1998). Corrosion Evaluation of Epoxy-Coated, Metallic-Clad and Solid Metalic Reinforcing Bars in Concrete. FHWA-RD-98-153. McLean, VA: Federal Highway Administration.

Mehta, P. K., \& Monteiro, P. J. M. (1993). Concrete: Structure, Properties and Materials. (W. J. Hall, Ed.) Englewood Cliffs, NJ: Prentice-Hall Inc.

Millard, S. G., Ghassemi, M. H., \& Bungey, J. H. (1990). Assessing the Electrical Resistivity of Concrete Structures for Corrosion Durability Studies. In C. L. Page, K. W. Treadaway, \& P. B. Bamforth (Eds.), Corrosion of Reinforcement in Concrete (pp. 303-313). New York: Elsevier Applied Science.

Millard, S. G., Law, D., Bungey, J. H., \& Cairns, J. (2001). Environmental Influences on Linear Polarisation Corrosion Rate Measurement in Reinforced Concrete. NDT \& E International, 34, 409-417.

Mindess, S., Young, J. F., \& Darwin, D. (2003). Concrete (2nd ed.). Upper Saddle River, NJ: Pearson Education Inc.

Otieno, M., Beushausen, H., \& Alexander, M. (2010). Prediction of Corrosion Rate in RC Structures - A Critical Review. In C. Andrade, \& G. Mancini (Ed.), Modelling of Corroding Concrete Structures, Proceedings of the Joint fib-RILEM Workshop held in Madrid, Spain, 22-23 November. 5, pp. 15-37. Madrid, Spain: Springer.

Pasupathy, P., Munukutla, S., Neikirk, D. P., \& Wood, S. L. (2009). Versatile Wireless Sacrificial Transducers for Electronic Structural Surveillance Sensors. IEEE Sensors 2009 Conference (pp. 979-983). Christchurch, New Zealand: IEEE. 
Poursaee, A. (2011). Corrosion Measurement Techniques in Steel Reinforced Concrete. Journal of ASTM International, 8(5).

Proceq SA. (2012). Operating Instructions; Corrosion Analyzing Instrument. canint.

Ramezanianpour, A. A., Ghahari, S. A., \& Esmaeili, M. (2014). Effect of Combined Carbonation and Chloride Ion Ingress by an Accelerated test Method on Microscopic and Mechanical Properties of Concrete. Construction and Building Materials, 58, 138-146.

Ramniceanu, A. (2004). Correlation of Corrosion Measurements and Bridge Conditions with NBIS Deck Rating. M.S. Thesis, Department of Civil and Environmental Engineering, Virginia Polytechnic Institute and State University, Blacksburg, Virginia.

Reis, R., \& Gallaher, M. (2006). Evaluation of the VTI ECI-1 Embedded Corrosion Instrument. Materials Engineering and Testing Services, California Department of Transportation, Sacranento, CA.

Robotshop Inc. (2015). Digital Temperature \& Humidity Sensor (With Stainless Steel Probe). Retrieved June 08, 2015, from http:/www.robotshop.com/en/digitaltemperature--humidity-sensor-with-stainless-steel-probe.html

SainSmart. (2015). SainSmart UNO ATMEGA328P-PU ATMEGA8U2 Microcontroller For Arduino. Retrieved 6 28, 2015, from http://www.sainsmart.com/sainsmartuno-atmega328p-pu-atmega8u2-microcontroller-for-arduino.html.

Schiessl, P., \& Lay, S. (2005). Influence of Concrete Composition. In H. Böhni (Ed.), Corrosion in Reinforced Concrete Structures. Cambridge, UK: Woodhead Publishing Limited.

Shetty, M. S. (2005). Concrete Technology: Theory and Practice. Ram Nagar, New Delhi: S. Chand \& Company Ltd.

Simon, T. K., \& Vass, V. (2012). The Electrical Resistivity of Concrete. Concrete Structures, 13, 61-64. 
Song, H.-W., \& Saraswathy, V. (2007). Corrosion Monitoring of Reinforced Concrete Structures - A Review. International Journal of Electrochemical Science, 2, 1-28.

Sterm, M., \& Weisert, E. D. (1958). Experimental Observations on the Relations between Polarization Resistance and Corrosion Rate. Proceedings of the American Society for Testing Materials, Vol. 59, pp. 1280-1290.

Trethewey, K. R., \& Chamberlain, J. (1995). Corrosion for Science and Engineering (2nd ed.). Harlow, Essex, England: Longman Group Limited.

USACE. (2014). Picture providey by U.S. Army Corps of Engineers (USACE), January 2014.

USDOT. (2015). Direct Measurement Methods... Retrieved June 08, 2015, from Central Federal Lands Highway, U.S. Department of Transportation (USDOT): http://www.cflhd.gov/resources/agm/engApplications/BridgeSystemSubstructure/ 231DirectMeasurementMethods.cfm.

Virginia Technologies, Inc (VTI). (2014). FAQ's. Retrieved July 5, 2015, from http:/corrosioninstrument.com/faqs/

Virginia Technologies, Inc. (2014). ECi Product \& Design. Retrieved March 25, 2015, from http://corrosioninstrument.com/eci-product-design/.

Xing, L., Darwin, D., \& Browning, J. (2010). Evaluation of Multiple Corrosion Protection Systems and Corrosion Inhibitors for Reinforced Concrete Bridge Decks. Research Report, FHWA Contract No. DTFH61-03-C-00131, KDOT Contract Nos. C1131 and C1281.

Yoon, I.-S. (2007). Deterioration of Concrete Due to Combined Reaction of Carbonation and Chloride Penetration: Experimental Study. Key Engineering Materials, 348349, 729-732. 


\section{APPENDiX A: PREliminary Design LAboratory DATA}

\section{Sample \#1}

\begin{tabular}{|c|c|c|c|c|c|c|}
\hline $\begin{array}{l}\text { Time } \\
\text { (Days) }\end{array}$ & $\begin{array}{l}\text { Weight, } \\
W_{\text {total }} \text { (g) }\end{array}$ & $\begin{array}{l}\text { Weight, } \\
W(\mathrm{~g})\end{array}$ & $\begin{array}{l}\text { Moisture } \\
\text { Content, w }\end{array}$ & $\begin{array}{l}\text { Bulk Density, } \\
\gamma_{\text {Moist }}\left(\mathrm{kg} / \mathrm{m}^{3}\right)\end{array}$ & $\begin{array}{c}\text { Resistance, } \\
R(\mathrm{k} \Omega)\end{array}$ & $\begin{array}{c}\text { Resistivity, } \\
\rho \text { (k } \Omega . \mathrm{m})\end{array}$ \\
\hline 0 & 1673.0 & 899.0 & 0.080 & 2201 & 5.5 & 0.4 \\
\hline 0 & 1673.0 & 899.0 & 0.080 & 2201 & 13.6 & 1.1 \\
\hline 0 & 1665.0 & 891.0 & 0.071 & 2181 & 90.0 & 7.4 \\
\hline 1 & 1662.0 & 888.0 & 0.067 & 2174 & 70.4 & 5.8 \\
\hline 2 & 1660.2 & 886.2 & 0.065 & 2169 & 121.6 & 10.0 \\
\hline 3 & 1661.9 & 887.9 & 0.067 & 2173 & 251.8 & 20.8 \\
\hline 7 & 1651.3 & 877.3 & 0.054 & 2147 & 322.7 & 26.6 \\
\hline 9 & 1646.2 & 872.2 & 0.048 & 2135 & 396.5 & 32.7 \\
\hline 10 & 1645.3 & 871.3 & 0.047 & 2133 & 502.8 & 41.5 \\
\hline 13 & 1642.8 & 868.8 & 0.044 & 2127 & 608.4 & 50.2 \\
\hline 14 & 1642.3 & 868.3 & 0.043 & 2125 & 611.1 & 50.4 \\
\hline 15 & 1642.2 & 868.2 & 0.043 & 2125 & 605.8 & 50.0 \\
\hline 16 & 1640.1 & 866.1 & 0.041 & 2120 & 729.0 & 60.1 \\
\hline 20 & 1636.0 & 862.0 & 0.036 & 2110 & 758.0 & 62.5 \\
\hline 21 & 1635.3 & 861.3 & 0.035 & 2108 & 760.0 & 62.7 \\
\hline 22 & 1635.1 & 861.1 & 0.035 & 2108 & 771.0 & 63.6 \\
\hline 23 & 1634.8 & 860.8 & 0.034 & 2107 & 801.0 & 66.1 \\
\hline 24 & 1634.5 & 860.5 & 0.034 & 2106 & 818.0 & 67.5 \\
\hline 35 & 1632.4 & 858.4 & 0.031 & 2101 & 1005.0 & 82.9 \\
\hline 38 & 1634.2 & 860.2 & 0.034 & 2106 & 1231.0 & 101.6 \\
\hline 41 & 1631.1 & 857.1 & 0.030 & 2098 & 1305.0 & 107.7 \\
\hline 44 & 1631.1 & 857.1 & 0.030 & 2098 & 1387.0 & 114.4 \\
\hline 48 & 1632.4 & 858.4 & 0.031 & 2101 & 1481.0 & 122.2 \\
\hline 50 & 1629.3 & 855.3 & 0.028 & 2094 & 1548.0 & 127.7 \\
\hline 55 & 1627.4 & 853.4 & 0.025 & 2089 & 1763.0 & 145.4 \\
\hline 57 & 1626.3 & 852.3 & 0.024 & 2086 & 1887.0 & 155.7 \\
\hline 70 & 1628.1 & 854.1 & 0.026 & 2091 & 2565.0 & 211.6 \\
\hline & \multicolumn{3}{|c|}{ Weight of mold } & 508.1 & \multicolumn{2}{|l|}{$g$} \\
\hline & \multicolumn{3}{|c|}{ Weight of Plates + Connectors } & 265.9 & \multicolumn{2}{|l|}{$g$} \\
\hline & \multicolumn{3}{|c|}{ Total extra weight } & 774.0 & \multicolumn{2}{|l|}{$g$} \\
\hline & \multicolumn{3}{|c|}{ Moisture content, $w_{\text {Lab } d r y}$} & $2.63 \%$ & \\
\hline & \multicolumn{3}{|c|}{ Weight of solids, $W_{\text {solids }}$} & 832.2 & $g$ & \\
\hline & \multicolumn{3}{|l|}{ Vol of cube } & 0.0004425 & \multicolumn{2}{|l|}{$m^{3}$} \\
\hline & \multicolumn{3}{|c|}{ Volume of plates } & 0.0000339 & \multicolumn{2}{|l|}{$m^{4}$} \\
\hline & \multicolumn{3}{|c|}{ Vol of concrete } & 0.0004085 & \multicolumn{2}{|l|}{$m^{5}$} \\
\hline & \multicolumn{3}{|c|}{ Lab dry density, $\gamma_{\text {Lab dry }}$} & 2091 & \multicolumn{2}{|l|}{$\mathrm{kg} / \mathrm{m}^{3}$} \\
\hline & \multicolumn{3}{|c|}{ Oven dry density, $\gamma_{d}$} & 2037 & \multicolumn{2}{|l|}{$\mathrm{kg} / \mathrm{m}^{4}$} \\
\hline
\end{tabular}


Electrical resistance and resistivity plots for sample \#1
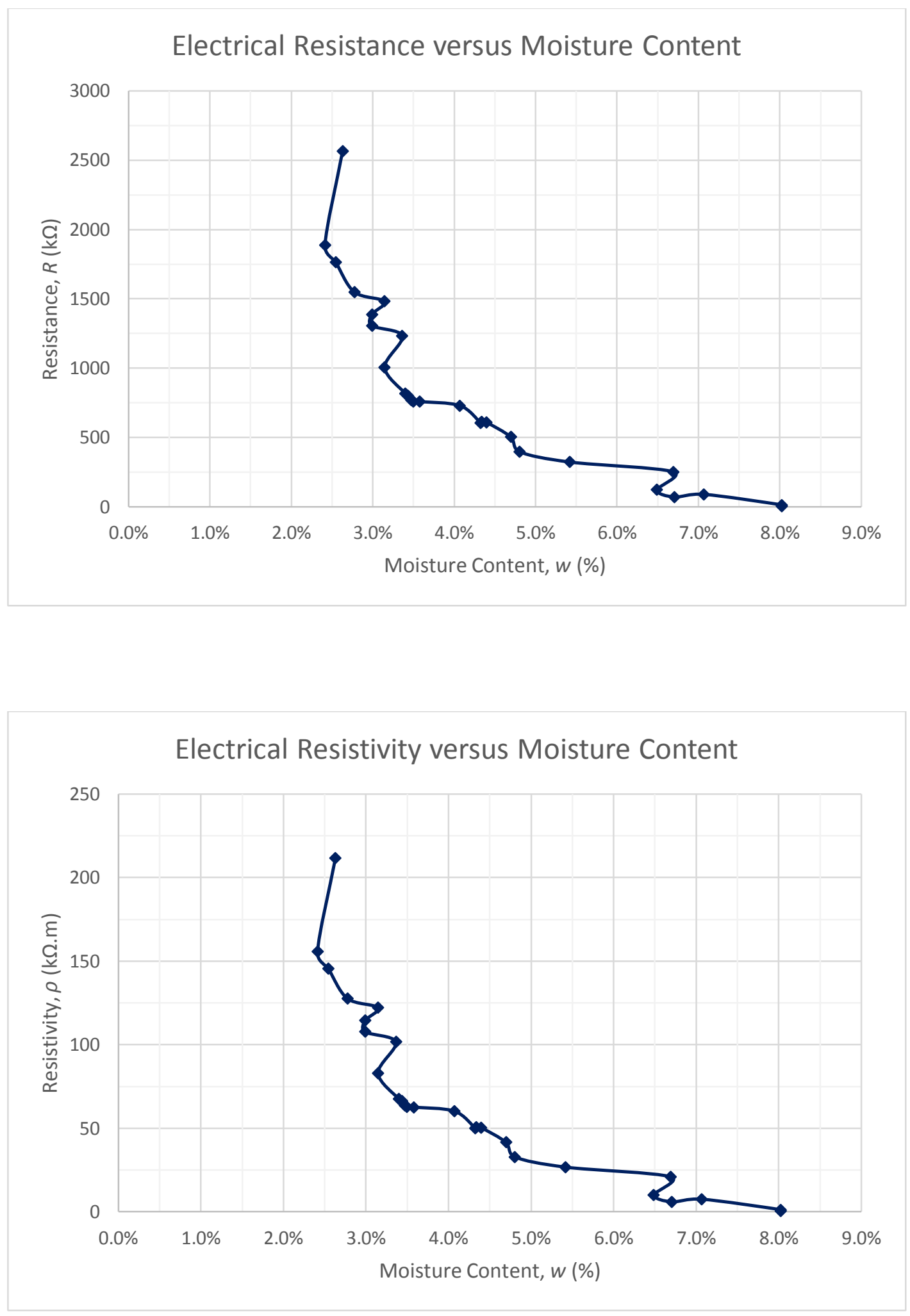


\section{Sample \#2}

\begin{tabular}{|c|c|c|c|c|c|c|}
\hline $\begin{array}{l}\text { Time } \\
\text { (Days) }\end{array}$ & $\begin{array}{l}\text { Weight, } \\
W_{\text {total }} \text { (g) }\end{array}$ & $\begin{array}{c}\text { Weight, } \\
\text { W (g) }\end{array}$ & $\begin{array}{l}\text { Moisture } \\
\text { Content, } w\end{array}$ & $\begin{array}{l}\text { Bulk Density, } \\
\gamma_{\text {Moist }}\left(\mathrm{kg} / \mathrm{m}^{3}\right)\end{array}$ & $\begin{array}{c}\text { Resistance, } \\
R(\mathrm{k} \Omega)\end{array}$ & $\begin{array}{c}\text { Resistivity, } \\
\rho \text { (k } \Omega . \mathrm{m})\end{array}$ \\
\hline 0 & 1678.8 & 904.8 & 0.075 & 2215 & 2.1 & 0.2 \\
\hline 0 & 1678.8 & 904.8 & 0.075 & 2215 & 37.3 & 3.1 \\
\hline 0 & 1670.3 & 896.3 & 0.065 & 2194 & 23.0 & 1.9 \\
\hline 1 & 1661.3 & 887.3 & 0.054 & 2172 & 58.8 & 4.9 \\
\hline 2 & 1662.3 & 888.3 & 0.056 & 2174 & 98.9 & 8.2 \\
\hline 3 & 1663.6 & 889.6 & 0.057 & 2178 & 182.9 & 15.1 \\
\hline 7 & 1655.5 & 881.5 & 0.048 & 2158 & 366.6 & 30.2 \\
\hline 9 & 1651.0 & 877.0 & 0.042 & 2147 & 323.8 & 26.7 \\
\hline 10 & 1650.2 & 876.2 & 0.041 & 2145 & 382.5 & 31.6 \\
\hline 13 & 1648.1 & 874.1 & 0.039 & 2140 & 438.8 & 36.2 \\
\hline 14 & 1648.4 & 874.4 & 0.039 & 2140 & 434.4 & 35.8 \\
\hline 15 & 1648.1 & 874.1 & 0.039 & 2140 & 507.9 & 41.9 \\
\hline 16 & 1646.0 & 872.0 & 0.036 & 2134 & 601.8 & 49.6 \\
\hline 20 & 1643.0 & 869.0 & 0.033 & 2127 & 658.8 & 54.4 \\
\hline 21 & 1642.1 & 868.1 & 0.032 & 2125 & 641.4 & 52.9 \\
\hline 22 & 1642.2 & 868.2 & 0.032 & 2125 & 752.0 & 62.0 \\
\hline 23 & 1642.6 & 868.6 & 0.032 & 2126 & 828.0 & 68.3 \\
\hline 24 & 1641.9 & 867.9 & 0.031 & 2124 & 923.0 & 76.1 \\
\hline 35 & 1639.6 & 865.6 & 0.029 & 2119 & 1209.0 & 99.7 \\
\hline 38 & 1642.5 & 868.5 & 0.032 & 2126 & 1689.0 & 139.3 \\
\hline 41 & 1639.5 & 865.5 & 0.029 & 2119 & 1818.0 & 150.0 \\
\hline 44 & 1639.5 & 865.5 & 0.029 & 2119 & 1613.0 & 133.1 \\
\hline 48 & 1641.2 & 867.2 & 0.031 & 2123 & 1809.0 & 149.2 \\
\hline 50 & 1638.1 & 864.1 & 0.027 & 2115 & 2305.0 & 190.2 \\
\hline 55 & 1636.6 & 862.6 & 0.025 & 2111 & 2297.0 & 189.5 \\
\hline 57 & 1635.5 & 861.5 & 0.024 & 2109 & 3041.0 & 250.9 \\
\hline 70 & 1637.6 & 863.6 & 0.026 & 2114 & 4421.0 & 364.7 \\
\hline & \multicolumn{3}{|c|}{ Weight of mold } & 508.1 & \multicolumn{2}{|l|}{$g$} \\
\hline & \multicolumn{3}{|c|}{ Weight of Plates + Connectors } & 265.9 & \multicolumn{2}{|l|}{$g$} \\
\hline & \multicolumn{3}{|c|}{ Total extra weight } & 774.0 & \multicolumn{2}{|l|}{$g$} \\
\hline & \multicolumn{3}{|c|}{ Moisture content, $\mathrm{w}_{\text {Lab dry }}$} & $2.63 \%$ & \\
\hline & \multicolumn{3}{|c|}{ Weight of solids, $W_{\text {solids }}$} & 841.5 & $g$ & \\
\hline & \multicolumn{3}{|l|}{ Vol of cube } & 0.0004425 & \multicolumn{2}{|l|}{$m^{3}$} \\
\hline & \multicolumn{3}{|c|}{ Volume of plates } & 0.0000339 & \multicolumn{2}{|l|}{$m^{4}$} \\
\hline & \multicolumn{3}{|c|}{ Vol of concrete } & 0.0004085 & \multicolumn{2}{|l|}{$m^{5}$} \\
\hline & \multicolumn{3}{|c|}{ Lab dry density, YLab dry } & 2114 & \multicolumn{2}{|l|}{$\mathrm{kg} / \mathrm{m}^{3}$} \\
\hline & \multicolumn{3}{|c|}{ Oven dry density, $\gamma_{d}$} & 2060 & \multicolumn{2}{|l|}{$\mathrm{kg} / \mathrm{m}^{4}$} \\
\hline
\end{tabular}




\section{Electrical resistance and resistivity plots for sample \#2}
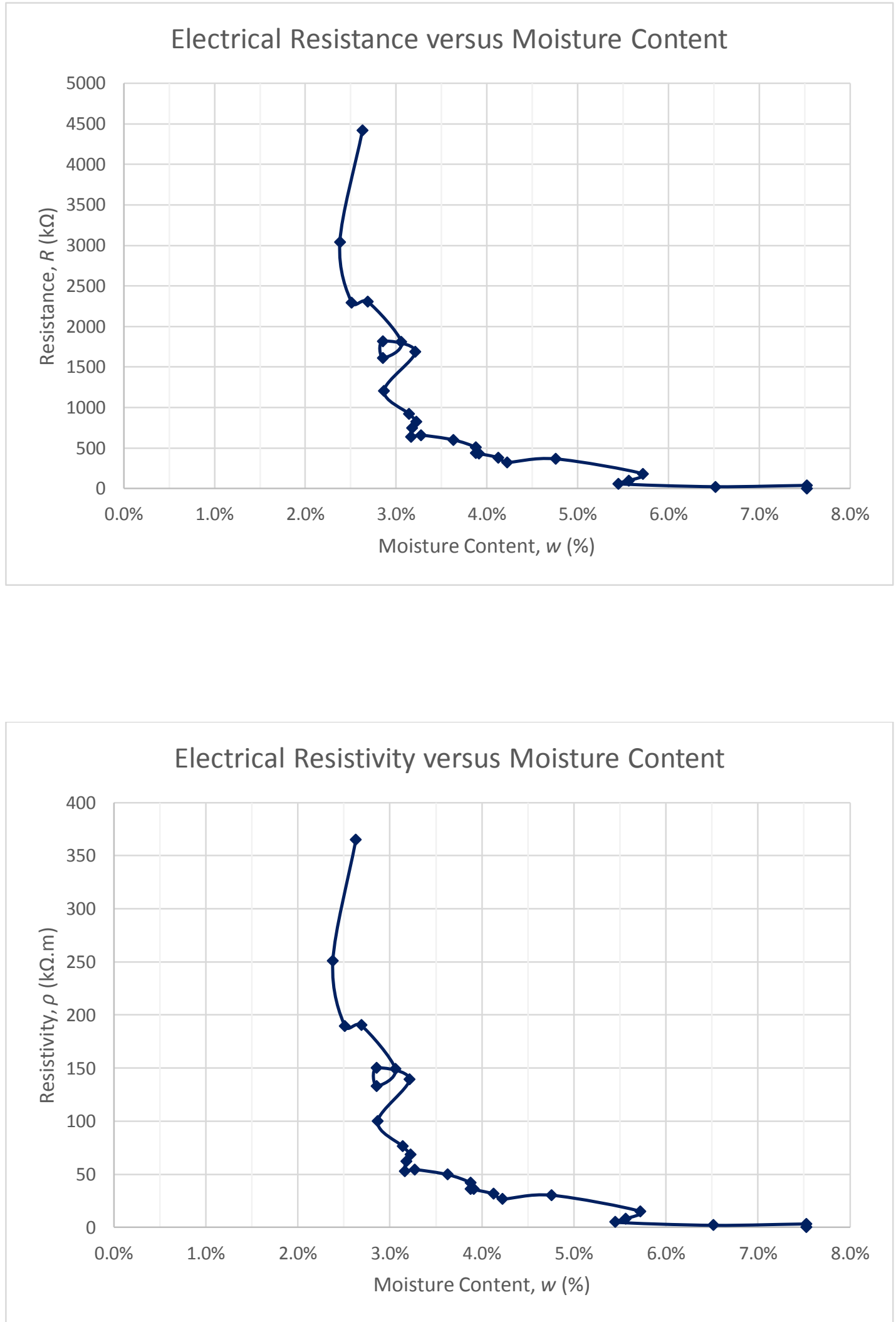


\section{Sample \#3}

\begin{tabular}{|c|c|c|c|c|c|c|}
\hline $\begin{array}{l}\text { Time } \\
\text { (Days) }\end{array}$ & $\begin{array}{l}\text { Weight, } \\
W_{\text {total }}(\mathrm{g})\end{array}$ & $\begin{array}{c}\text { Weight, } \\
W(\mathrm{~g})\end{array}$ & $\begin{array}{l}\text { Moisture } \\
\text { Content, } w\end{array}$ & $\begin{array}{l}\text { Bulk Density, } \\
\gamma_{\text {Moist }}\left(\mathrm{kg} / \mathrm{m}^{3}\right)\end{array}$ & $\begin{array}{c}\text { Resistance, } \\
R(\mathrm{k} \Omega)\end{array}$ & $\begin{array}{c}\text { Resistivity, } \\
\rho \text { (k } \Omega . \mathrm{m})\end{array}$ \\
\hline 0 & 1672.3 & 898.3 & 0.068 & 2199 & 92.7 & 7.6 \\
\hline 0 & 1672.3 & 898.3 & 0.068 & 2199 & 95.7 & 7.9 \\
\hline 0 & 1665.9 & 891.9 & 0.060 & 2183 & 19.4 & 1.6 \\
\hline 1 & 1658.7 & 884.7 & 0.051 & 2166 & 60.8 & 5.0 \\
\hline 2 & 1659.9 & 885.9 & 0.053 & 2169 & 90.4 & 7.5 \\
\hline 3 & 1661.8 & 887.8 & 0.055 & 2173 & 193.0 & 15.9 \\
\hline 7 & 1654.8 & 880.8 & 0.047 & 2156 & 272.0 & 22.4 \\
\hline 9 & 1650.1 & 876.1 & 0.041 & 2145 & No Data & No Data \\
\hline 10 & 1649.4 & 875.4 & 0.040 & 2143 & 313.2 & 25.8 \\
\hline 13 & 1647.4 & 873.4 & 0.038 & 2138 & 386.0 & 31.8 \\
\hline 14 & 1647.5 & 873.5 & 0.038 & 2138 & 342.3 & 28.2 \\
\hline 15 & 1647.4 & 873.4 & 0.038 & 2138 & 409.5 & 33.8 \\
\hline 16 & 1645.6 & 871.6 & 0.036 & 2134 & 394.8 & 32.6 \\
\hline 20 & 1642.6 & 868.6 & 0.032 & 2126 & 414.6 & 34.2 \\
\hline 21 & 1641.8 & 867.8 & 0.031 & 2124 & 465.4 & 38.4 \\
\hline 22 & 1641.8 & 867.8 & 0.031 & 2124 & 483.3 & 39.9 \\
\hline 23 & 1641.8 & 867.8 & 0.031 & 2124 & 522.3 & 43.1 \\
\hline 24 & 1641.5 & 867.5 & 0.031 & 2123 & 606.0 & 50.0 \\
\hline 35 & 1639.5 & 865.5 & 0.029 & 2119 & 932.0 & 76.9 \\
\hline 38 & 1642.5 & 868.5 & 0.032 & 2126 & 1053.0 & 86.9 \\
\hline 41 & 1639.4 & 865.4 & 0.028 & 2118 & 1094.0 & 90.3 \\
\hline 44 & 1639.5 & 865.5 & 0.029 & 2119 & 1224.0 & 101.0 \\
\hline 48 & 1641.2 & 867.2 & 0.031 & 2123 & 1497.0 & 123.5 \\
\hline 50 & 1637.9 & 863.9 & 0.027 & 2115 & 1814.0 & 149.7 \\
\hline 55 & 1636.5 & 862.5 & 0.025 & 2111 & 1460.0 & 120.5 \\
\hline 57 & 1635.5 & 861.5 & 0.024 & 2109 & 1525.0 & 125.8 \\
\hline 70 & 1637.6 & 863.6 & 0.026 & 2114 & 2270.0 & 187.3 \\
\hline & \multicolumn{3}{|c|}{ Weight of mold } & 508.1 & \multicolumn{2}{|l|}{$g$} \\
\hline & \multicolumn{3}{|c|}{ Weight of Plates + Connectors } & 265.9 & \multicolumn{2}{|l|}{$g$} \\
\hline & \multicolumn{3}{|c|}{ Total extra weight } & 774.0 & \multicolumn{2}{|l|}{$g$} \\
\hline & \multicolumn{3}{|c|}{ Moisture content, $\mathrm{w}_{\text {Lab dry }}$} & $2.63 \%$ & \\
\hline & \multicolumn{3}{|c|}{ Weight of solids, $W_{\text {solids }}$} & 841.5 & $g$ & \\
\hline & \multicolumn{3}{|l|}{ Vol of cube } & 0.0004425 & \multicolumn{2}{|l|}{$m^{3}$} \\
\hline & \multicolumn{3}{|c|}{ Volume of plates } & 0.0000339 & \multicolumn{2}{|l|}{$m^{4}$} \\
\hline & \multicolumn{3}{|c|}{ Vol of concrete } & 0.0004085 & \multicolumn{2}{|l|}{$m^{5}$} \\
\hline & \multicolumn{3}{|c|}{ Lab dry density, YLab dry } & 2114 & \multicolumn{2}{|l|}{$\mathrm{kg} / \mathrm{m}^{3}$} \\
\hline & \multicolumn{3}{|c|}{ Oven dry density, $\gamma_{d}$} & 2060 & \multicolumn{2}{|l|}{$\mathrm{kg} / \mathrm{m}^{4}$} \\
\hline
\end{tabular}




\section{Electrical resistance and resistivity plots for sample \#3}
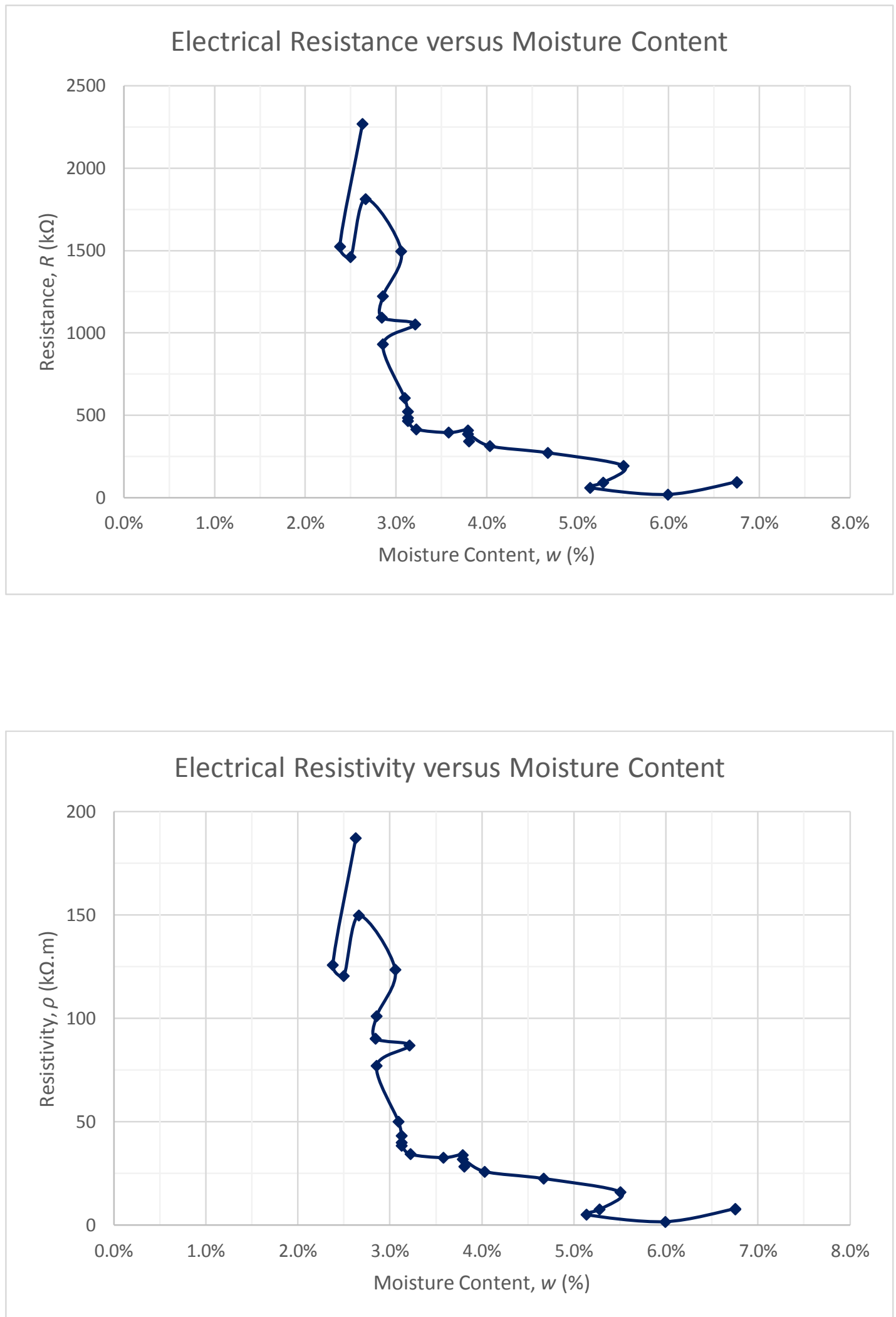


\section{Sample \#4}

\begin{tabular}{|c|c|c|c|c|c|c|}
\hline $\begin{array}{l}\text { Time } \\
\text { (Days) }\end{array}$ & $\begin{array}{l}\text { Weight, } \\
\text { W }_{\text {total }} \text { (g) }\end{array}$ & $\begin{array}{c}\text { Weight, W } \\
\text { (g) }\end{array}$ & $\begin{array}{c}\text { Moisture } \\
\text { Content, w }\end{array}$ & $\begin{array}{l}\text { Bulk Density, } \\
\gamma_{\text {Moist }}\left(\mathrm{kg} / \mathrm{m}^{3}\right)\end{array}$ & $\begin{array}{c}\text { Resistance, } \\
R(\mathrm{k} \Omega)\end{array}$ & $\begin{array}{c}\text { Resistivity, } \\
\rho \text { (k } \Omega . \mathrm{m})\end{array}$ \\
\hline 0 & 1685.7 & 911.7 & 0.068 & 2232 & 27.0 & 2.2 \\
\hline 0 & 1685.7 & 911.7 & 0.068 & 2232 & 73.5 & 6.1 \\
\hline 0 & 1676.7 & 902.7 & 0.058 & 2210 & 17.1 & 1.4 \\
\hline 1 & 1670.0 & 896.0 & 0.050 & 2193 & 90.2 & 7.4 \\
\hline 2 & 1673.1 & 899.1 & 0.054 & 2201 & 147.7 & 12.2 \\
\hline 3 & 1673.8 & 899.8 & 0.054 & 2203 & 181.3 & 15.0 \\
\hline 7 & 1665.1 & 891.1 & 0.044 & 2181 & 307.5 & 25.4 \\
\hline 9 & 1661.6 & 887.6 & 0.040 & 2173 & No Data & No Data \\
\hline 10 & 1660.9 & 886.9 & 0.039 & 2171 & 381.6 & 31.5 \\
\hline 13 & 1659.3 & 885.3 & 0.037 & 2167 & 421.9 & 34.8 \\
\hline 14 & 1659.3 & 885.3 & 0.037 & 2167 & 394.0 & 32.5 \\
\hline 15 & 1659.0 & 885.0 & 0.037 & 2166 & 410.5 & 33.9 \\
\hline 16 & 1657.6 & 883.6 & 0.035 & 2163 & 478.0 & 39.4 \\
\hline 20 & 1654.3 & 880.3 & 0.032 & 2155 & 584.2 & 48.2 \\
\hline 21 & 1653.5 & 879.5 & 0.031 & 2153 & 592.2 & 48.9 \\
\hline 22 & 1653.6 & 879.6 & 0.031 & 2153 & 620.3 & 51.2 \\
\hline 23 & 1653.6 & 879.6 & 0.031 & 2153 & 773.0 & 63.8 \\
\hline 24 & 1653.3 & 879.3 & 0.030 & 2152 & 734.0 & 60.6 \\
\hline 35 & 1651.1 & 877.1 & 0.028 & 2147 & 1201.0 & 99.1 \\
\hline 38 & 1654.7 & 880.7 & 0.032 & 2156 & 1170.0 & 96.5 \\
\hline 41 & 1651.6 & 877.6 & 0.028 & 2148 & 1533.0 & 126.5 \\
\hline 44 & 1651.7 & 877.7 & 0.029 & 2148 & 1348.0 & 111.2 \\
\hline 48 & 1653.6 & 879.6 & 0.031 & 2153 & 1659.0 & 136.9 \\
\hline 50 & 1650.0 & 876.0 & 0.027 & 2144 & 1699.0 & 140.2 \\
\hline 55 & 1648.7 & 874.7 & 0.025 & 2141 & 1849.0 & 152.5 \\
\hline 57 & 1647.7 & 873.7 & 0.024 & 2139 & 1768.0 & 145.9 \\
\hline 70 & 1649.8 & 875.8 & 0.026 & 2144 & 2268.0 & 187.1 \\
\hline & \multicolumn{3}{|c|}{ Weight of mold } & 508.1 & $g$ & \\
\hline & \multicolumn{3}{|c|}{ Weight of Plates + Connectors } & 265.9 & $g$ & \\
\hline & \multicolumn{3}{|c|}{ Total extra weight } & 774.0 & $g$ & \\
\hline & \multicolumn{3}{|c|}{ Moisture content, $\mathrm{w}_{\text {Lab dry }}$} & $2.63 \%$ & & \\
\hline & \multicolumn{3}{|c|}{ Weight of solids, $W_{\text {Solids }}$} & 853.4 & $g$ & \\
\hline & \multicolumn{3}{|l|}{ Vol of cube } & 0.0004425 & $m^{3}$ & \\
\hline & \multicolumn{3}{|c|}{ Volume of plates } & 0.0000339 & $m^{4}$ & \\
\hline & \multicolumn{3}{|c|}{ Vol of concrete } & 0.0004085 & $m^{5}$ & \\
\hline & \multicolumn{3}{|c|}{ Lab dry density, $\gamma_{\text {Lab dry }}$} & 2144 & $\mathrm{~kg} / \mathrm{m}^{3}$ & \\
\hline & \multicolumn{3}{|c|}{ Oven dry density, $\gamma_{d}$} & 2089 & $\mathrm{~kg} / \mathrm{m}^{4}$ & \\
\hline
\end{tabular}




\section{Electrical resistance and resistivity plots for sample \#4}
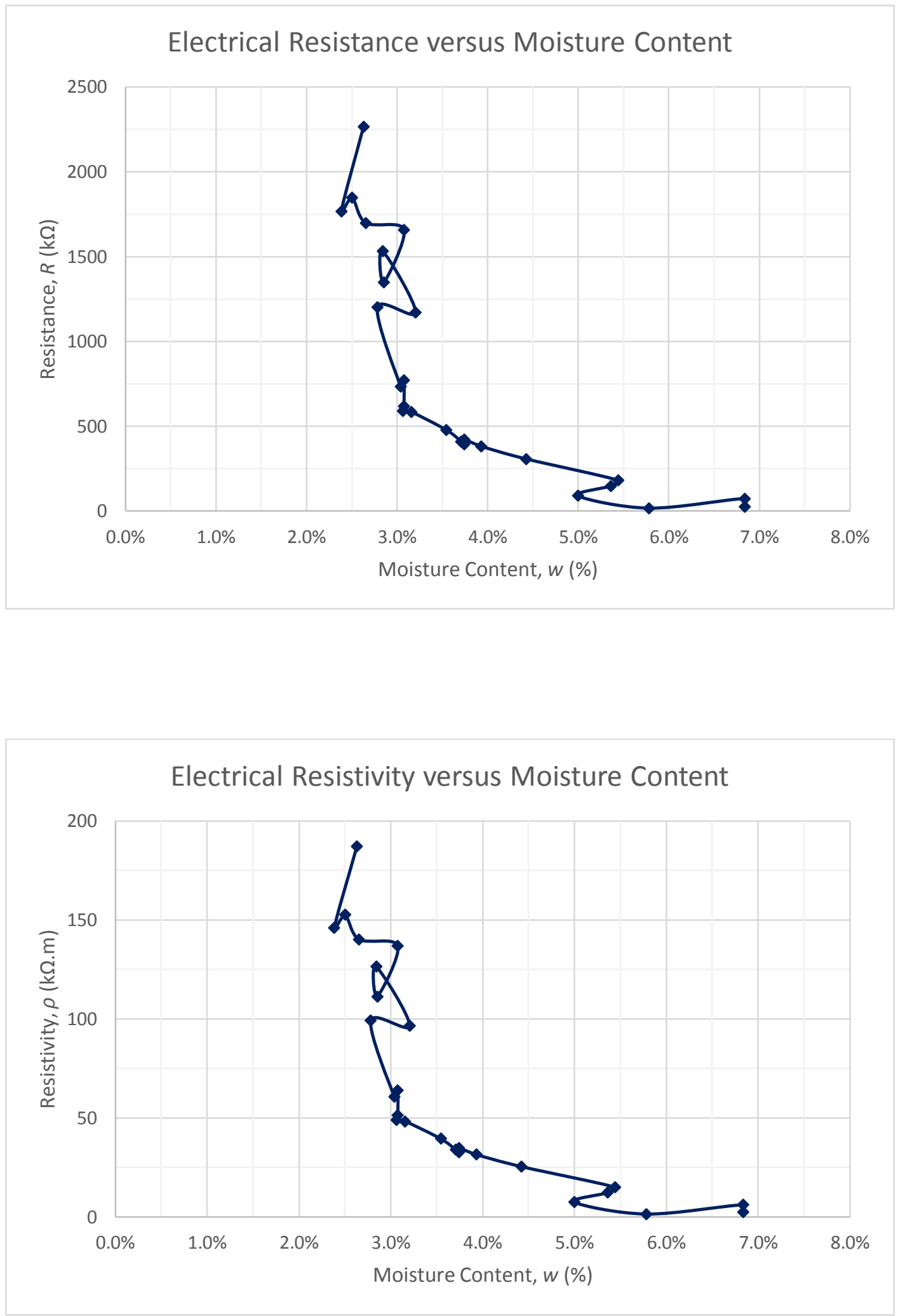


\section{APPENDIX B: LABORATORY CALIBRATION DATA}

This Appendix presents detail laboratory data and graphs for samples R1, R2 and T-H1.

The following data apply to all samples:

Lab dry moisture content, $\mathrm{W}_{\text {Lab dry }}=3.30 \%$.

$$
\begin{aligned}
& W_{\text {Solids }}=\frac{W_{\text {Lab dry }}}{1+w_{\text {Lab dry }}} \\
& w=W\left(\frac{1+w_{\text {Lab dry }}}{W_{\text {Lab dry }}}\right)-1
\end{aligned}
$$

$\operatorname{Density}\left(\gamma_{\text {Moist }}, \mathrm{kg} / \mathrm{m}^{3}\right)=\frac{\text { Weight }(\mathrm{kg})}{\text { Volume of cube }\left(\mathrm{m}^{3}\right)}$

Lab dry density $\left(\gamma_{\text {Lab dry }}, \mathrm{kg} / \mathrm{m}^{3}\right)=\frac{\text { Lab dry weight }(\mathrm{kg})}{\text { Volume of cube }\left(\mathrm{m}^{3}\right)}$

Oven dry density $\left(\gamma_{d}, \mathrm{~kg} / \mathrm{m}^{3}\right)=\frac{\text { Oven dry weight }(\mathrm{kg})}{\text { Volume of cube }\left(\mathrm{m}^{3}\right)}$

Oven dry specific gravity

$$
\begin{gathered}
=\frac{\text { Oven dry density }\left(\gamma_{d}, \mathrm{~kg} / \mathrm{m}^{3}\right)}{\text { Density of water }\left(\gamma_{w}, \mathrm{~kg} / \mathrm{m}^{3}\right)} \\
\quad=\frac{\text { Oven dry density }\left(\gamma_{d}, \mathrm{~kg} / \mathrm{m}^{3}\right)}{1,000\left(\mathrm{~kg} / \mathrm{m}^{3}\right)}
\end{gathered}
$$

For samples R1 and R2;

Volume of concrete, $V_{\text {Conc }}=$ Volume of cube $\left(V_{\text {Cube }}\right)-$ Volume of plates $\left(V_{\text {Plates }}\right)$

$$
\begin{aligned}
& =0.1016^{3}-2 \times\left(0.0762^{2} \times 0.002921\right) \\
& =0.001049-0.000034 \\
& =0.001015 \mathrm{~m}^{3}
\end{aligned}
$$


Lab dry density and density of solids (oven dry densities) for sample R1 are $2111 \mathrm{~kg} / \mathrm{m}^{3}$ and $2044 \mathrm{~kg} / \mathrm{m}^{3}$ respectively.

Lab dry density and density of solids (oven dry densities) for sample R2 are $2146 \mathrm{~kg} / \mathrm{m}^{3}$ and $2077 \mathrm{~kg} / \mathrm{m}^{3}$ respectively.

For samples T-H1;

Volume of concrete, $\mathrm{V}_{\text {Conc }}=$ Volume of cube $\left(\mathrm{V}_{\text {Cube }}\right)-$ Volume of sensor hole $\left(\mathrm{V}_{\text {Sensor hole }}\right)$

$$
\begin{aligned}
& =0.1016^{3}-2 \times\left(0.0762^{2} \times 0.002921\right) \\
& =0.001049-0.000034 \\
& =0.001015 \mathrm{~m}^{3}
\end{aligned}
$$

Lab dry density and density of solids (oven dry densities) for sample T-H1 are $2280 \mathrm{~kg} / \mathrm{m}^{3}$ and $2207 \mathrm{~kg} / \mathrm{m}^{3}$ respectively.

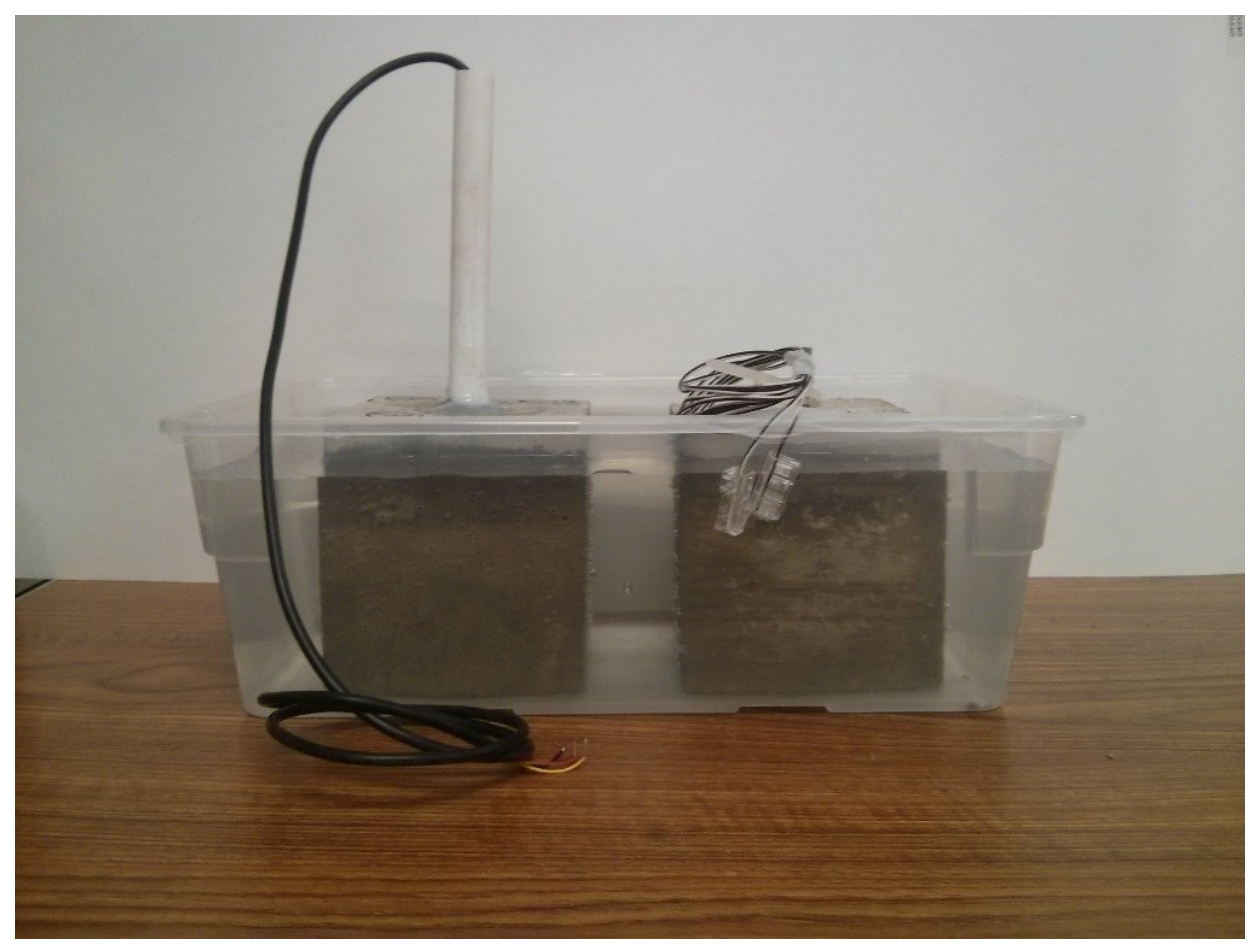

Figure B-1: Soaked samples 


\section{Data for sample R1}

\begin{tabular}{|c|c|c|c|c|c|c|}
\hline $\begin{array}{l}\text { Time } \\
\text { (Days) }\end{array}$ & $\begin{array}{l}\text { Weight, } \\
W_{\text {Total }} \text { (g) }\end{array}$ & $\begin{array}{c}\text { Weight, } \\
\text { W (g) }\end{array}$ & $\begin{array}{l}\text { Moisture } \\
\text { Content, w }\end{array}$ & $\begin{array}{c}\text { Density, } \\
\gamma_{\text {Moist }}\left(\mathrm{kg} / \mathrm{m}^{3}\right)\end{array}$ & $\begin{array}{c}\text { Resistance, } \\
R(\mathrm{k} \Omega)\end{array}$ & $\begin{array}{c}\text { Resistivity, } \\
\rho \text { (k } \Omega . \mathrm{m})\end{array}$ \\
\hline 0 & 2568.5 & 2295.4 & 0.108 & 2262 & 3.4 & 0.5 \\
\hline 1 & 2526.6 & 2253.5 & 0.088 & 2220 & 7.5 & 1.1 \\
\hline 2 & 2513.4 & 2240.3 & 0.081 & 2207 & 9.7 & 1.5 \\
\hline 3 & 2505.7 & 2232.6 & 0.078 & 2200 & 10.7 & 1.6 \\
\hline 4 & 2500.1 & 2227.0 & 0.075 & 2194 & 12.5 & 1.9 \\
\hline 5 & 2495.5 & 2222.4 & 0.073 & 2190 & 20.7 & 3.1 \\
\hline 6 & 2491.5 & 2218.4 & 0.071 & 2186 & 23.4 & 3.6 \\
\hline 7 & 2488.7 & 2215.6 & 0.069 & 2183 & 26.7 & 4.1 \\
\hline 8 & 2485.1 & 2212.0 & 0.068 & 2180 & 32.7 & 5.0 \\
\hline 9 & 2514.8 & 2208.9 & 0.066 & 2177 & 36.7 & 5.6 \\
\hline 10 & 2512.3 & 2206.4 & 0.065 & 2174 & 50.2 & 7.7 \\
\hline 11 & 2509.9 & 2204.0 & 0.064 & 2172 & 55.3 & 8.4 \\
\hline 12 & 2507.6 & 2201.7 & 0.063 & 2170 & 62.0 & 9.4 \\
\hline 13 & 2505.7 & 2199.8 & 0.062 & 2168 & 65.4 & 10.0 \\
\hline 14 & 2503.8 & 2197.9 & 0.061 & 2166 & 93.8 & 14.3 \\
\hline 15 & 2502.4 & 2196.5 & 0.060 & 2164 & 107.0 & 16.3 \\
\hline 16 & 2500.8 & 2194.9 & 0.059 & 2163 & 84.5 & 12.9 \\
\hline 17 & 2499.3 & 2193.4 & 0.059 & 2161 & 98.2 & 15.0 \\
\hline 18 & 2497.7 & 2191.8 & 0.058 & 2160 & 92.0 & 14.0 \\
\hline 19 & 2496.4 & 2190.5 & 0.057 & 2158 & 93.1 & 14.2 \\
\hline 20 & 2495.0 & 2189.1 & 0.057 & 2157 & 77.8 & 11.9 \\
\hline 21 & 2494.2 & 2188.3 & 0.056 & 2156 & 80.7 & 12.3 \\
\hline 22 & 2493.3 & 2187.4 & 0.056 & 2155 & 96.1 & 14.6 \\
\hline 23 & 2492.1 & 2186.2 & 0.055 & 2154 & 93.1 & 14.2 \\
\hline 24 & 2491.1 & 2185.2 & 0.055 & 2153 & 94.5 & 14.4 \\
\hline 25 & 2490.4 & 2184.5 & 0.054 & 2153 & 92.5 & 14.1 \\
\hline 26 & 2489.7 & 2183.8 & 0.054 & 2152 & 100.8 & 15.4 \\
\hline 27 & 2489.1 & 2183.2 & 0.054 & 2151 & 120.8 & 18.4 \\
\hline 28 & 2488.4 & 2182.5 & 0.053 & 2151 & 160.9 & 24.5 \\
\hline 29 & 2487.6 & 2181.7 & 0.053 & 2150 & 253.5 & 38.6 \\
\hline 30 & 2486.8 & 2180.9 & 0.053 & 2149 & 276.7 & 42.2 \\
\hline 31 & 2486.3 & 2180.4 & 0.052 & 2149 & 284.5 & 43.4 \\
\hline 32 & 2485.3 & 2179.4 & 0.052 & 2148 & 307.5 & 46.9 \\
\hline 33 & 2484.8 & 2178.9 & 0.052 & 2147 & 309.2 & 47.1 \\
\hline 34 & 2484.7 & 2178.8 & 0.052 & 2147 & 326.5 & 49.8 \\
\hline 35 & 2484.2 & 2178.3 & 0.051 & 2146 & 356.8 & 54.4 \\
\hline 36 & 2483.5 & 2177.6 & 0.051 & 2146 & 393.9 & 60.0 \\
\hline 37 & 2482.9 & 2177.0 & 0.051 & 2145 & 408.0 & 62.2 \\
\hline 38 & 2482.4 & 2176.5 & 0.050 & 2145 & 418.9 & 63.8 \\
\hline
\end{tabular}




\section{Data for sample R1 (continued)}

\begin{tabular}{|c|c|c|c|c|c|c|}
\hline $\begin{array}{l}\text { Time } \\
\text { (Days) }\end{array}$ & $\begin{array}{l}\text { Weight, } \\
W_{\text {Total }} \text { (g) }\end{array}$ & $\begin{array}{c}\text { Weight, } \\
W(\mathrm{~g})\end{array}$ & $\begin{array}{l}\text { Moisture } \\
\text { Content, w }\end{array}$ & $\begin{array}{c}\text { Density, } \\
\gamma_{\text {Moist }}\left(\mathrm{kg} / \mathrm{m}^{3}\right)\end{array}$ & $\begin{array}{l}\text { Resistance, } \\
\quad R(\mathrm{k} \Omega)\end{array}$ & $\begin{array}{c}\text { Resistivity, } \\
\rho \text { (k } \Omega . \mathrm{m})\end{array}$ \\
\hline 39 & 2481.8 & 2175.9 & 0.049 & 2144 & 433.4 & 66.1 \\
\hline 40 & 2481.2 & 2175.3 & 0.049 & 2144 & 437.2 & 66.6 \\
\hline 41 & 2480.8 & 2174.9 & 0.049 & 2143 & 454.9 & 69.3 \\
\hline 42 & 2480.4 & 2174.5 & 0.048 & 2143 & 445.1 & 67.8 \\
\hline 43 & 2480.0 & 2174.1 & 0.048 & 2142 & 487.2 & 74.2 \\
\hline 44 & 2479.5 & 2173.6 & 0.048 & 2142 & 487.1 & 74.2 \\
\hline 45 & 2479.1 & 2173.2 & 0.048 & 2141 & 469.4 & 71.5 \\
\hline 46 & 2478.8 & 2172.9 & 0.048 & 2141 & 511.4 & 77.9 \\
\hline 47 & 2478.3 & 2172.4 & 0.047 & 2141 & 518.4 & 79.0 \\
\hline 48 & 2478.2 & 2172.3 & 0.047 & 2141 & 532.9 & 81.2 \\
\hline 49 & 2477.7 & 2171.8 & 0.047 & 2140 & 530.6 & 80.9 \\
\hline 50 & 2477.5 & 2171.6 & 0.047 & 2140 & 531.6 & 81.0 \\
\hline 51 & 2477.2 & 2171.3 & 0.047 & 2140 & 536.3 & 81.7 \\
\hline 52 & 2476.6 & 2170.7 & 0.047 & 2139 & 592.0 & 90.2 \\
\hline 53 & 2476.4 & 2170.5 & 0.047 & 2139 & 548.5 & 83.6 \\
\hline 54 & 2476.1 & 2170.2 & 0.046 & 2138 & 552.6 & 84.2 \\
\hline 55 & 2475.9 & 2170.0 & 0.046 & 2138 & 556.1 & 84.7 \\
\hline 56 & 2475.6 & 2169.7 & 0.046 & 2138 & 568.9 & 86.7 \\
\hline 57 & 2475.2 & 2169.3 & 0.046 & 2138 & 584.1 & 89.0 \\
\hline 58 & 2475.1 & 2169.2 & 0.046 & 2138 & 592.1 & 90.2 \\
\hline 59 & 2474.8 & 2168.9 & 0.046 & 2137 & 602.8 & 91.9 \\
\hline 60 & 2474.6 & 2168.7 & 0.046 & 2137 & 580.3 & 88.4 \\
\hline 61 & 2474.4 & 2168.5 & 0.046 & 2137 & 601.2 & 91.6 \\
\hline 62 & 2474.2 & 2168.3 & 0.045 & 2137 & 598.6 & 91.2 \\
\hline 63 & 2473.9 & 2168.0 & 0.045 & 2136 & 609.0 & 92.8 \\
\hline 64 & 2473.5 & 2167.6 & 0.045 & 2136 & 610.9 & 93.1 \\
\hline 65 & 2473.4 & 2167.5 & 0.045 & 2136 & 601.2 & 91.6 \\
\hline 66 & 2473.2 & 2167.3 & 0.045 & 2136 & 617.4 & 94.1 \\
\hline 67 & 2472.9 & 2167.0 & 0.045 & 2135 & 644.0 & 98.1 \\
\hline 68 & 2472.8 & 2166.9 & 0.045 & 2135 & 623.8 & 95.1 \\
\hline 69 & 2472.6 & 2166.7 & 0.045 & 2135 & 633.4 & 96.5 \\
\hline 70 & 2472.5 & 2166.6 & 0.045 & 2135 & 646.0 & 98.5 \\
\hline 71 & 2472.3 & 2166.4 & 0.045 & 2135 & 633.5 & 96.5 \\
\hline 72 & 2472.0 & 2166.1 & 0.044 & 2134 & 637.6 & 97.2 \\
\hline 73 & 2471.6 & 2165.7 & 0.044 & 2134 & 655.2 & 99.9 \\
\hline 74 & 2471.8 & 2165.9 & 0.044 & 2134 & 646.1 & 98.5 \\
\hline 75 & 2471.5 & 2165.6 & 0.044 & 2134 & No Data & No Data \\
\hline 76 & 2471.4 & 2165.5 & 0.044 & 2134 & 652.0 & 99.4 \\
\hline 77 & 2471.2 & 2165.3 & 0.044 & 2134 & 713.0 & 108.7 \\
\hline
\end{tabular}




\section{Data for sample R1 (continued)}

\begin{tabular}{|c|c|c|c|c|c|c|}
\hline $\begin{array}{l}\text { Time } \\
\text { (Days) }\end{array}$ & $\begin{array}{l}\text { Weight, } \\
W_{\text {Total }} \text { (g) }\end{array}$ & $\begin{array}{c}\text { Weight, } \\
W(\mathrm{~g})\end{array}$ & $\begin{array}{l}\text { Moisture } \\
\text { Content, w }\end{array}$ & $\begin{array}{c}\text { Density, } \\
\gamma_{\text {Moist }}\left(\mathrm{kg} / \mathrm{m}^{3}\right)\end{array}$ & $\begin{array}{l}\text { Resistance, } \\
\quad R(\mathrm{k} \Omega)\end{array}$ & $\begin{array}{c}\text { Resistivity, } \\
\rho \text { (k } \Omega . \mathrm{m})\end{array}$ \\
\hline 78 & 2471.0 & 2165.1 & 0.044 & 2133 & 657.8 & 100.2 \\
\hline 79 & 2470.8 & 2164.9 & 0.044 & 2133 & 648.9 & 98.9 \\
\hline 80 & 2470.7 & 2164.8 & 0.044 & 2133 & 701.0 & 106.8 \\
\hline 81 & 2470.5 & 2164.6 & 0.044 & 2133 & 712.0 & 108.5 \\
\hline 82 & 2470.3 & 2164.4 & 0.044 & 2133 & 707.0 & 107.7 \\
\hline 83 & 2470.0 & 2164.1 & 0.043 & 2132 & 703.0 & 107.1 \\
\hline 84 & 2469.7 & 2163.8 & 0.043 & 2132 & 703.0 & 107.1 \\
\hline 85 & 2469.6 & 2163.7 & 0.043 & 2132 & 720.0 & 109.7 \\
\hline 86 & 2469.5 & 2163.6 & 0.043 & 2132 & 711.0 & 108.4 \\
\hline 87 & 2469.3 & 2163.4 & 0.043 & 2132 & 704.0 & 107.3 \\
\hline 88 & 2469.1 & 2163.2 & 0.043 & 2132 & 710.0 & 108.2 \\
\hline 89 & 2468.9 & 2163.0 & 0.043 & 2131 & 705.0 & 107.4 \\
\hline 90 & 2468.8 & 2162.9 & 0.043 & 2131 & 712.0 & 108.5 \\
\hline 91 & 2468.7 & 2162.8 & 0.043 & 2131 & 725.0 & 110.5 \\
\hline 92 & 2468.4 & 2162.5 & 0.043 & 2131 & 723.0 & 110.2 \\
\hline 93 & 2468.2 & 2162.3 & 0.043 & 2131 & 724.0 & 110.3 \\
\hline 94 & 2468.2 & 2162.3 & 0.043 & 2131 & 727.0 & 110.8 \\
\hline 95 & 2467.9 & 2162.0 & 0.042 & 2130 & 725.0 & 110.5 \\
\hline 96 & 2467.9 & 2162.0 & 0.042 & 2130 & 729.0 & 111.1 \\
\hline 97 & 2467.8 & 2161.9 & 0.042 & 2130 & No Data & No Data \\
\hline 98 & 2467.7 & 2161.8 & 0.042 & 2130 & 730.0 & 111.3 \\
\hline 99 & 2467.6 & 2161.7 & 0.042 & 2130 & 747.0 & 113.8 \\
\hline 100 & 2467.5 & 2161.6 & 0.042 & 2130 & 745.0 & 113.5 \\
\hline 101 & 2467.4 & 2161.5 & 0.042 & 2130 & 740.0 & 112.8 \\
\hline 102 & 2467.4 & 2161.5 & 0.042 & 2130 & 745.0 & 113.5 \\
\hline 103 & 2467.0 & 2161.1 & 0.042 & 2130 & 746.0 & 113.7 \\
\hline 104 & 2466.2 & 2160.3 & 0.042 & 2129 & 754.0 & 114.9 \\
\hline 105 & 2466.1 & 2160.2 & 0.042 & 2129 & 749.0 & 114.1 \\
\hline 106 & 2466.1 & 2160.2 & 0.042 & 2129 & 750.0 & 114.3 \\
\hline 107 & 2466.0 & 2160.1 & 0.042 & 2129 & 750.0 & 114.3 \\
\hline 108 & 2465.9 & 2160.0 & 0.041 & 2128 & 755.0 & 115.1 \\
\hline 109 & 2465.8 & 2159.9 & 0.041 & 2128 & 761.0 & 116.0 \\
\hline 110 & 2465.6 & 2159.7 & 0.041 & 2128 & 760.0 & 115.8 \\
\hline 111 & 2465.5 & 2159.6 & 0.041 & 2128 & 761.0 & 116.0 \\
\hline 112 & 2465.6 & 2159.7 & 0.041 & 2128 & 759.0 & 115.7 \\
\hline 113 & 2465.8 & 2159.9 & 0.041 & 2128 & 760.0 & 115.8 \\
\hline 114 & 2465.5 & 2159.6 & 0.041 & 2128 & 771.0 & 117.5 \\
\hline 115 & 2465.6 & 2159.7 & 0.041 & 2128 & 768.0 & 117.0 \\
\hline 116 & 2465.4 & 2159.5 & 0.041 & 2128 & 770.0 & 117.3 \\
\hline
\end{tabular}




\section{Data for sample R1 (continued)}

\begin{tabular}{|c|c|c|c|c|c|c|}
\hline $\begin{array}{l}\text { Time } \\
\text { (Days) }\end{array}$ & $\begin{array}{l}\text { Weight, } \\
W_{\text {Total }} \text { (g) }\end{array}$ & $\begin{array}{c}\text { Weight, } \\
W(\mathrm{~g})\end{array}$ & $\begin{array}{l}\text { Moisture } \\
\text { Content, w }\end{array}$ & $\begin{array}{c}\text { Density, } \\
\gamma_{\text {Moist }}\left(\mathrm{kg} / \mathrm{m}^{3}\right)\end{array}$ & $\begin{array}{l}\text { Resistance, } \\
\quad R(\mathrm{k} \Omega)\end{array}$ & $\begin{array}{c}\text { Resistivity, } \\
\rho \text { (k } \Omega . \mathrm{m})\end{array}$ \\
\hline 117 & 2464.0 & 2158.1 & 0.041 & 2127 & 764.0 & 116.4 \\
\hline 118 & 2464.4 & 2158.5 & 0.041 & 2127 & 765.0 & 116.6 \\
\hline 119 & 2464.1 & 2158.2 & 0.041 & 2127 & 768.0 & 117.0 \\
\hline 120 & 2464.2 & 2158.3 & 0.041 & 2127 & 772.0 & 117.7 \\
\hline 121 & 2464.2 & 2158.3 & 0.041 & 2127 & 772.0 & 117.7 \\
\hline 122 & 2463.8 & 2157.9 & 0.040 & 2126 & 773.0 & 117.8 \\
\hline 123 & 2463.6 & 2157.7 & 0.040 & 2126 & 776.0 & 118.3 \\
\hline 124 & 2463.6 & 2157.7 & 0.040 & 2126 & 783.0 & 119.3 \\
\hline 125 & 2463.1 & 2157.2 & 0.040 & 2126 & 787.0 & 119.9 \\
\hline 126 & 2462.8 & 2156.9 & 0.040 & 2125 & 785.0 & 119.6 \\
\hline 127 & 2463.0 & 2157.1 & 0.040 & 2126 & 782.0 & 119.2 \\
\hline 128 & 2463.0 & 2157.1 & 0.040 & 2126 & 788.0 & 120.1 \\
\hline 129 & 2462.6 & 2156.7 & 0.040 & 2125 & 789.0 & 120.2 \\
\hline 130 & 2462.3 & 2156.4 & 0.040 & 2125 & 788.0 & 120.1 \\
\hline 131 & 2461.9 & 2156.0 & 0.040 & 2124 & 779.0 & 118.7 \\
\hline 132 & 2461.2 & 2155.3 & 0.039 & 2124 & 781.0 & 119.0 \\
\hline 133 & 2460.8 & 2154.9 & 0.039 & 2123 & No Data & No Data \\
\hline 134 & 2460.1 & 2154.2 & 0.039 & 2123 & 790.0 & 120.4 \\
\hline 135 & 2460.5 & 2154.6 & 0.039 & 2123 & 796.0 & 121.3 \\
\hline 136 & 2460.7 & 2154.8 & 0.039 & 2123 & 794.0 & 121.0 \\
\hline 137 & 2460.2 & 2154.3 & 0.039 & 2123 & 794.0 & 121.0 \\
\hline 140 & 2459.1 & 2153.2 & 0.038 & 2122 & 799.0 & 121.8 \\
\hline 141 & 2458.9 & 2153.0 & 0.038 & 2122 & 805.0 & 122.7 \\
\hline 142 & 2458.5 & 2152.6 & 0.038 & 2121 & 807.0 & 123.0 \\
\hline 143 & 2458.2 & 2152.3 & 0.038 & 2121 & 810.0 & 123.4 \\
\hline 144 & 2457.7 & 2151.8 & 0.038 & 2120 & 812.0 & 123.7 \\
\hline 147 & 2457.0 & 2151.1 & 0.037 & 2120 & 820.0 & 125.0 \\
\hline 148 & 2456.4 & 2150.5 & 0.037 & 2119 & 820.0 & 125.0 \\
\hline 149 & 2456.0 & 2150.1 & 0.037 & 2119 & 824.0 & 125.6 \\
\hline 150 & 2455.3 & 2149.4 & 0.036 & 2118 & 821.0 & 125.1 \\
\hline 151 & 2455.0 & 2149.1 & 0.036 & 2118 & 820.0 & 125.0 \\
\hline 154 & 2455.6 & 2149.7 & 0.037 & 2118 & 834.0 & 127.1 \\
\hline 155 & 2455.3 & 2149.4 & 0.036 & 2118 & 848.0 & 129.2 \\
\hline 156 & 2454.9 & 2149.0 & 0.036 & 2118 & 839.0 & 127.9 \\
\hline 158 & 2454.0 & 2148.1 & 0.036 & 2117 & 840.0 & 128.0 \\
\hline 161 & 2454.5 & 2148.6 & 0.036 & 2117 & 842.0 & 128.3 \\
\hline 162 & 2454.1 & 2148.2 & 0.036 & 2117 & 841.0 & 128.2 \\
\hline 163 & 2454.3 & 2148.4 & 0.036 & 2117 & 842.0 & 128.3 \\
\hline 164 & 2453.6 & 2147.7 & 0.036 & 2116 & 846.0 & 128.9 \\
\hline
\end{tabular}




\section{Data for sample R1 (continued)}

\begin{tabular}{|c|c|c|c|c|c|c|}
\hline $\begin{array}{l}\text { Time } \\
\text { (Days) }\end{array}$ & $\begin{array}{l}\text { Weight, } \\
W_{\text {Total }} \text { (g) }\end{array}$ & $\begin{array}{l}\text { Weight, } \\
W(\mathrm{~g})\end{array}$ & $\begin{array}{l}\text { Moisture } \\
\text { Content, w }\end{array}$ & $\begin{array}{c}\text { Density, } \\
\gamma_{\text {Moist }}\left(\mathrm{kg} / \mathrm{m}^{3}\right)\end{array}$ & $\begin{array}{l}\text { Resistance, } \\
\quad R(\mathrm{k} \Omega)\end{array}$ & $\begin{array}{c}\text { Resistivity, } \\
\rho \text { (k } \Omega . \mathrm{m})\end{array}$ \\
\hline 165 & 2453.7 & 2147.8 & 0.036 & 2116 & 850.0 & 129.5 \\
\hline 168 & 2452.7 & 2146.8 & 0.035 & 2115 & 842.0 & 128.3 \\
\hline 169 & 2452.7 & 2146.8 & 0.035 & 2115 & 848.0 & 129.2 \\
\hline 171 & 2452.0 & 2146.1 & 0.035 & 2115 & 858.0 & 130.8 \\
\hline 172 & 2451.9 & 2146.0 & 0.035 & 2115 & 863.0 & 131.5 \\
\hline 175 & 2451.8 & 2145.9 & 0.035 & 2115 & 878.0 & 133.8 \\
\hline 176 & 2452.2 & 2146.3 & 0.035 & 2115 & 890.0 & 135.6 \\
\hline 177 & 2451.9 & 2146.0 & 0.035 & 2115 & 900.0 & 137.2 \\
\hline 178 & 2451.5 & 2145.6 & 0.035 & 2114 & 895.0 & 136.4 \\
\hline 179 & 2451.2 & 2145.3 & 0.034 & 2114 & 897.0 & 136.7 \\
\hline 182 & 2450.7 & 2144.8 & 0.034 & 2113 & 898.0 & 136.9 \\
\hline 183 & 2451.0 & 2145.1 & 0.034 & 2114 & 891.0 & 135.8 \\
\hline 184 & 2451.4 & 2145.5 & 0.034 & 2114 & 881.0 & 134.3 \\
\hline 186 & 2450.8 & 2144.9 & 0.034 & 2114 & 899.0 & 137.0 \\
\hline 189 & 2450.5 & 2144.6 & 0.034 & 2113 & 927.0 & 141.3 \\
\hline 190 & 2450.1 & 2144.2 & 0.034 & 2113 & 932.0 & 142.0 \\
\hline 191 & 2449.7 & 2143.8 & 0.034 & 2112 & 927.0 & 141.3 \\
\hline 193 & 2449.2 & 2143.3 & 0.033 & 2112 & 928.0 & 141.4 \\
\hline 196 & 2449.3 & 2143.4 & 0.033 & 2112 & 929.0 & 141.6 \\
\hline 197 & 2449.0 & 2143.1 & 0.033 & 2112 & 934.0 & 142.3 \\
\hline 198 & 2448.8 & 2142.9 & 0.033 & 2112 & 944.0 & 143.9 \\
\hline 200 & 2448.2 & 2142.3 & 0.033 & 2111 & 936.0 & 142.6 \\
\hline 203 & 2448.0 & 2142.1 & 0.033 & 2111 & 927.0 & 141.3 \\
\hline 204 & 2447.7 & 2141.8 & 0.033 & 2111 & 931.0 & 141.9 \\
\hline 205 & 2447.5 & 2141.6 & 0.033 & 2110 & 945.0 & 144.0 \\
\hline 206 & 2447.3 & 2141.4 & 0.033 & 2110 & 954.0 & 145.4 \\
\hline 207 & 2447.2 & 2141.3 & 0.032 & 2110 & 952.0 & 145.1 \\
\hline 210 & 2446.8 & 2140.9 & 0.032 & 2110 & 950.0 & 144.8 \\
\hline 211 & 2446.6 & 2140.7 & 0.032 & 2109 & 948.0 & 144.5 \\
\hline 212 & 2446.5 & 2140.6 & 0.032 & 2109 & 950.0 & 144.8 \\
\hline 213 & 2446.3 & 2140.4 & 0.032 & 2109 & 972.0 & 148.1 \\
\hline 214 & 2446.0 & 2140.1 & 0.032 & 2109 & 965.0 & 147.1 \\
\hline 217 & 2445.8 & 2139.9 & 0.032 & 2109 & 963.0 & 146.8 \\
\hline 218 & 2445.5 & 2139.6 & 0.032 & 2108 & 974.0 & 148.4 \\
\hline 219 & 2445.1 & 2139.2 & 0.031 & 2108 & 1012.0 & 154.2 \\
\hline 220 & 2445.0 & 2139.1 & 0.031 & 2108 & 992.0 & 151.2 \\
\hline 221 & 2444.9 & 2139.0 & 0.031 & 2108 & 982.0 & 149.7 \\
\hline 224 & 2444.7 & 2138.8 & 0.031 & 2108 & 1011.0 & 154.1 \\
\hline 225 & 2444.4 & 2138.5 & 0.031 & 2107 & 1020.0 & 155.4 \\
\hline
\end{tabular}




\section{Data for sample R1 (continued)}

\begin{tabular}{|c|c|c|c|c|c|c|}
\hline $\begin{array}{l}\text { Time } \\
\text { (Days) }\end{array}$ & $\begin{array}{l}\text { Weight, } \\
W_{\text {Total }} \text { (g) }\end{array}$ & $\begin{array}{c}\text { Weight, } \\
W(g)\end{array}$ & $\begin{array}{c}\text { Moisture } \\
\text { Content, w }\end{array}$ & $\begin{array}{c}\text { Density, } \\
\gamma_{\text {Moist }}\left(\mathrm{kg} / \mathrm{m}^{3}\right)\end{array}$ & $\begin{array}{c}\text { Resistance, } \\
\quad R(\mathrm{k} \Omega)\end{array}$ & $\begin{array}{c}\text { Resistivity, } \\
\rho \text { (k } \Omega . \mathrm{m})\end{array}$ \\
\hline 226 & 2444.2 & 2138.3 & 0.031 & 2107 & No Data & No Data \\
\hline 227 & 2444.1 & 2138.2 & 0.031 & 2107 & 1080.0 & 164.6 \\
\hline 228 & 2443.8 & 2137.9 & 0.031 & 2107 & 1080.0 & 164.6 \\
\hline 231 & 2444.3 & 2138.4 & 0.031 & 2107 & 1101.0 & 167.8 \\
\hline 232 & 2444.1 & 2138.2 & 0.031 & 2107 & 1116.0 & 170.1 \\
\hline 233 & 2444.1 & 2138.2 & 0.031 & 2107 & 1126.0 & 171.6 \\
\hline 234 & 2444.1 & 2138.2 & 0.031 & 2107 & 1131.0 & 172.4 \\
\hline 235 & 2443.7 & 2137.8 & 0.031 & 2107 & 1135.0 & 173.0 \\
\hline 238 & 2443.1 & 2137.2 & 0.030 & 2106 & 1138.0 & 173.4 \\
\hline 239 & 2443.1 & 2137.2 & 0.030 & 2106 & 1148.0 & 175.0 \\
\hline 240 & 2443.1 & 2137.2 & 0.030 & 2106 & 1151.0 & 175.4 \\
\hline 241 & 2442.7 & 2136.8 & 0.030 & 2106 & 1163.0 & 177.2 \\
\hline 242 & 2442.6 & 2136.7 & 0.030 & 2105 & 1170.0 & 178.3 \\
\hline 245 & 2442.8 & 2136.9 & 0.030 & 2106 & 1182.0 & 180.1 \\
\hline 246 & 2442.6 & 2136.7 & 0.030 & 2105 & 1211.0 & 184.6 \\
\hline 247 & 2442.6 & 2136.7 & 0.030 & 2105 & 1212.0 & 184.7 \\
\hline 248 & 2442.5 & 2136.6 & 0.030 & 2105 & 1221.0 & 186.1 \\
\hline 249 & 2442.5 & 2136.6 & 0.030 & 2105 & 1251.0 & 190.7 \\
\hline 252 & 2442.5 & 2136.6 & 0.030 & 2105 & 1249.0 & 190.3 \\
\hline 253 & 2442.5 & 2136.6 & 0.030 & 2105 & 1252.0 & 190.8 \\
\hline 254 & 2443.2 & 2137.3 & 0.031 & 2106 & 1284.0 & 195.7 \\
\hline 256 & 2442.6 & 2136.7 & 0.030 & 2105 & 1281.0 & 195.2 \\
\hline 259 & 2442.7 & 2136.8 & 0.030 & 2106 & 1285.0 & 195.8 \\
\hline 260 & 2443.0 & 2137.1 & 0.030 & 2106 & 1301.0 & 198.3 \\
\hline 261 & 2443.5 & 2137.6 & 0.031 & 2106 & 1286.0 & 196.0 \\
\hline 262 & 2443.3 & 2137.4 & 0.031 & 2106 & 1306.0 & 199.0 \\
\hline 263 & 2442.9 & 2137.0 & 0.030 & 2106 & 1278.0 & 194.8 \\
\hline 266 & 2443.5 & 2137.6 & 0.031 & 2106 & 1262.0 & 192.3 \\
\hline 267 & 2443.6 & 2137.7 & 0.031 & 2106 & 1262.0 & 192.3 \\
\hline 268 & 2443.1 & 2137.2 & 0.030 & 2106 & 1313.0 & 200.1 \\
\hline 269 & 2442.9 & 2137.0 & 0.030 & 2106 & 1323.0 & 201.6 \\
\hline 270 & 2443.2 & 2137.3 & 0.031 & 2106 & 1328.0 & 202.4 \\
\hline 273 & 2442.8 & 2136.9 & 0.030 & 2106 & 1358.0 & 207.0 \\
\hline 274 & 2442.7 & 2136.8 & 0.030 & 2106 & 1346.0 & 205.1 \\
\hline 275 & 2443.0 & 2137.1 & 0.030 & 2106 & 1284.0 & 195.7 \\
\hline 276 & 2443.4 & 2137.5 & 0.031 & 2106 & 1322.0 & 201.5 \\
\hline 277 & 2443.3 & 2137.4 & 0.031 & 2106 & 1408.0 & 214.6 \\
\hline 280 & 2442.8 & 2136.9 & 0.030 & 2106 & 1378.0 & 210.0 \\
\hline 282 & 2442.7 & 2136.8 & 0.030 & 2106 & 1386.0 & 211.2 \\
\hline
\end{tabular}




\section{Data for sample R1 (continued)}

\begin{tabular}{|c|c|c|c|c|c|c|}
\hline $\begin{array}{l}\text { Time } \\
\text { (Days) }\end{array}$ & $\begin{array}{l}\text { Weight, } \\
W_{\text {Total }}(\mathrm{g})\end{array}$ & $\begin{array}{c}\text { Weight, } \\
W(g)\end{array}$ & $\begin{array}{c}\text { Moisture } \\
\text { Content, w }\end{array}$ & $\begin{array}{c}\text { Density, } \\
\gamma_{\text {Moist }}\left(\mathrm{kg} / \mathrm{m}^{3}\right)\end{array}$ & $\begin{array}{c}\text { Resistance, } \\
R(\mathrm{k} \Omega)\end{array}$ & $\begin{array}{c}\text { Resistivity, } \\
\rho \text { (k } \Omega . \mathrm{m})\end{array}$ \\
\hline 283 & 2442.7 & 2136.8 & 0.030 & 2106 & 1461.0 & 222.7 \\
\hline 284 & 2443.7 & 2137.8 & 0.031 & 2107 & 1366.0 & 208.2 \\
\hline 287 & 2443.6 & 2137.7 & 0.031 & 2106 & 1398.0 & 213.1 \\
\hline 288 & 2443.6 & 2137.7 & 0.031 & 2106 & 1406.0 & 214.3 \\
\hline 289 & 2444.1 & 2138.2 & 0.031 & 2107 & 1466.0 & 223.4 \\
\hline 290 & 2444.4 & 2138.5 & 0.031 & 2107 & 1438.0 & 219.2 \\
\hline 294 & 2444.3 & 2138.4 & 0.031 & 2107 & 1448.0 & 220.7 \\
\hline 295 & 2444.5 & 2138.6 & 0.031 & 2107 & 1494.0 & 227.7 \\
\hline 296 & 2444.2 & 2138.3 & 0.031 & 2107 & 1476.0 & 224.9 \\
\hline 297 & 2444.0 & 2138.1 & 0.031 & 2107 & 1477.0 & 225.1 \\
\hline 298 & 2444.7 & 2138.8 & 0.031 & 2108 & 1480.0 & 225.6 \\
\hline 301 & 2445.1 & 2139.2 & 0.031 & 2108 & 1448.0 & 220.7 \\
\hline 302 & 2444.8 & 2138.9 & 0.031 & 2108 & 1439.0 & 219.3 \\
\hline 303 & 2444.5 & 2138.6 & 0.031 & 2107 & 1451.0 & 221.1 \\
\hline 304 & 2444.3 & 2138.4 & 0.031 & 2107 & 1456.0 & 221.9 \\
\hline 305 & 2444.0 & 2138.1 & 0.031 & 2107 & 1400.0 & 213.4 \\
\hline 308 & 2444.0 & 2138.1 & 0.031 & 2107 & 1472.0 & 224.3 \\
\hline 309 & 2444.0 & 2138.1 & 0.031 & 2107 & 1501.0 & 228.8 \\
\hline 310 & 2444.1 & 2138.2 & 0.031 & 2107 & 1528.0 & 232.9 \\
\hline 311 & 2444.1 & 2138.2 & 0.031 & 2107 & 1521.0 & 231.8 \\
\hline 312 & 2444.2 & 2138.3 & 0.031 & 2107 & 1528.0 & 232.9 \\
\hline 315 & 2444.7 & 2138.8 & 0.031 & 2108 & 1535.0 & 233.9 \\
\hline 316 & 2445.2 & 2139.3 & 0.032 & 2108 & 1476.0 & 224.9 \\
\hline 317 & 2445.3 & 2139.4 & 0.032 & 2108 & 1473.0 & 224.5 \\
\hline 318 & 2445.5 & 2139.6 & 0.032 & 2108 & 1470.0 & 224.0 \\
\hline 319 & 2445.5 & 2139.6 & 0.032 & 2108 & 1480.0 & 225.6 \\
\hline 322 & 2445.9 & 2140.0 & 0.032 & 2109 & 1426.0 & 217.3 \\
\hline 323 & 2446.0 & 2140.1 & 0.032 & 2109 & 1414.0 & 215.5 \\
\hline 324 & 2445.7 & 2139.8 & 0.032 & 2109 & 1403.0 & 213.8 \\
\hline 325 & 2445.6 & 2139.7 & 0.032 & 2108 & 1415.0 & 215.6 \\
\hline 326 & 2445.8 & 2139.9 & 0.032 & 2109 & 1395.0 & 212.6 \\
\hline 329 & 2446.6 & 2140.7 & 0.032 & 2109 & 1348.0 & 205.4 \\
\hline 330 & 2446.5 & 2140.6 & 0.032 & 2109 & 1284.0 & 195.7 \\
\hline 331 & 2446.5 & 2140.6 & 0.032 & 2109 & 1372.0 & 209.1 \\
\hline 332 & 2446.4 & 2140.5 & 0.032 & 2109 & 1354.0 & 206.3 \\
\hline 333 & 2446.2 & 2140.3 & 0.032 & 2109 & 1353.0 & 206.2 \\
\hline 340 & 2447.1 & 2141.2 & 0.032 & 2110 & 1349.0 & 205.6 \\
\hline 347 & 2448.3 & 2142.4 & 0.033 & 2111 & 1283.0 & 195.5 \\
\hline 350 & 2448.1 & 2142.2 & 0.033 & 2111 & 1180.0 & 179.8 \\
\hline
\end{tabular}




\section{Data for sample R1 (continued)}

\begin{tabular}{|r|r|r|r|r|r|r||}
\hline \hline $\begin{array}{c}\text { Time } \\
\text { (Days) }\end{array}$ & $\begin{array}{c}\text { Weight, } \\
\boldsymbol{W}_{\text {Total }} \mathbf{( g )}\end{array}$ & $\begin{array}{c}\text { Weight, } \\
\boldsymbol{W} \mathbf{( g )}\end{array}$ & $\begin{array}{c}\text { Moisture } \\
\text { Content, } \boldsymbol{w}\end{array}$ & $\begin{array}{c}\text { Density, } \\
\gamma_{\text {Moist }}\left(\mathbf{k g} / \mathbf{m}^{\mathbf{3}}\right)\end{array}$ & $\begin{array}{c}\text { Resistance, } \\
\boldsymbol{R}(\mathbf{k} \boldsymbol{\Omega})\end{array}$ & $\begin{array}{c}\text { Resistivity, } \\
\boldsymbol{\rho}(\mathbf{k} \boldsymbol{\Omega} . \mathbf{m})\end{array}$ \\
\hline 352 & 2447.9 & 2142.0 & 0.033 & 2111 & 1240.0 & 189.0 \\
\hline 354 & 2448.0 & 2142.1 & 0.033 & 2111 & 1236.0 & 188.4 \\
\hline 357 & 2448.1 & 2142.2 & 0.033 & 2111 & 1232.0 & 187.8 \\
\hline 359 & 2448.0 & 2142.1 & 0.033 & 2111 & 1227.0 & 187.0 \\
\hline 360 & 2448.1 & 2142.2 & 0.033 & 2111 & 1236.0 & 188.4 \\
\hline 361 & 2448.1 & 2142.2 & 0.033 & 2111 & 1238.0 & 188.7 \\
\hline 364 & 2448.2 & 2142.3 & 0.033 & 2111 & 1229.0 & 187.3 \\
\hline 365 & 2448.3 & 2142.4 & 0.033 & 2111 & 1207.0 & 183.9 \\
\hline 368 & 2448.3 & 2142.4 & 0.033 & 2111 & 1214.0 & 185.0 \\
\hline
\end{tabular}




\section{Electrical resistivity and moisture content plots for sample R1}
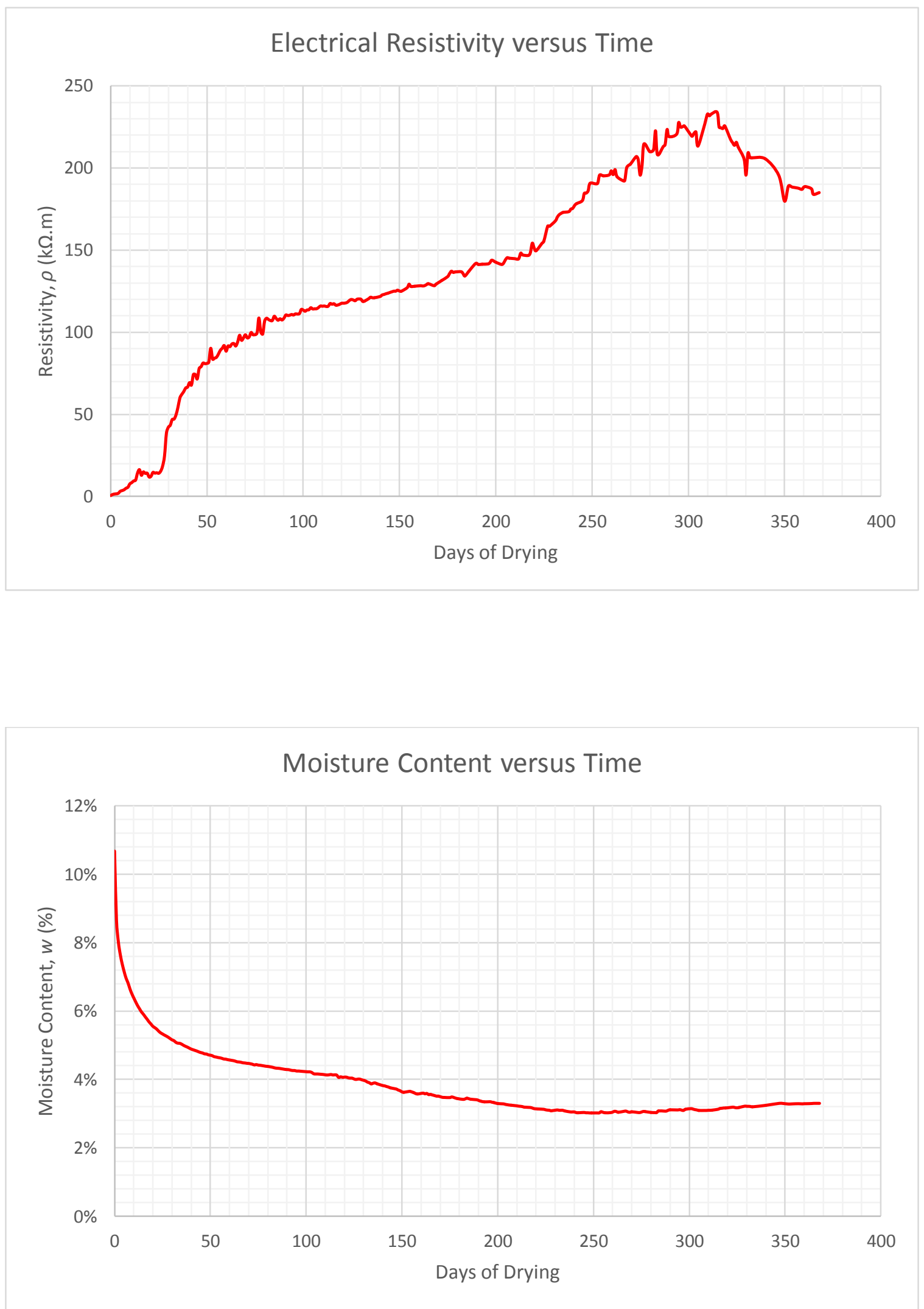


\section{Electrical resistivity plots for sample $\mathrm{R} 1$}
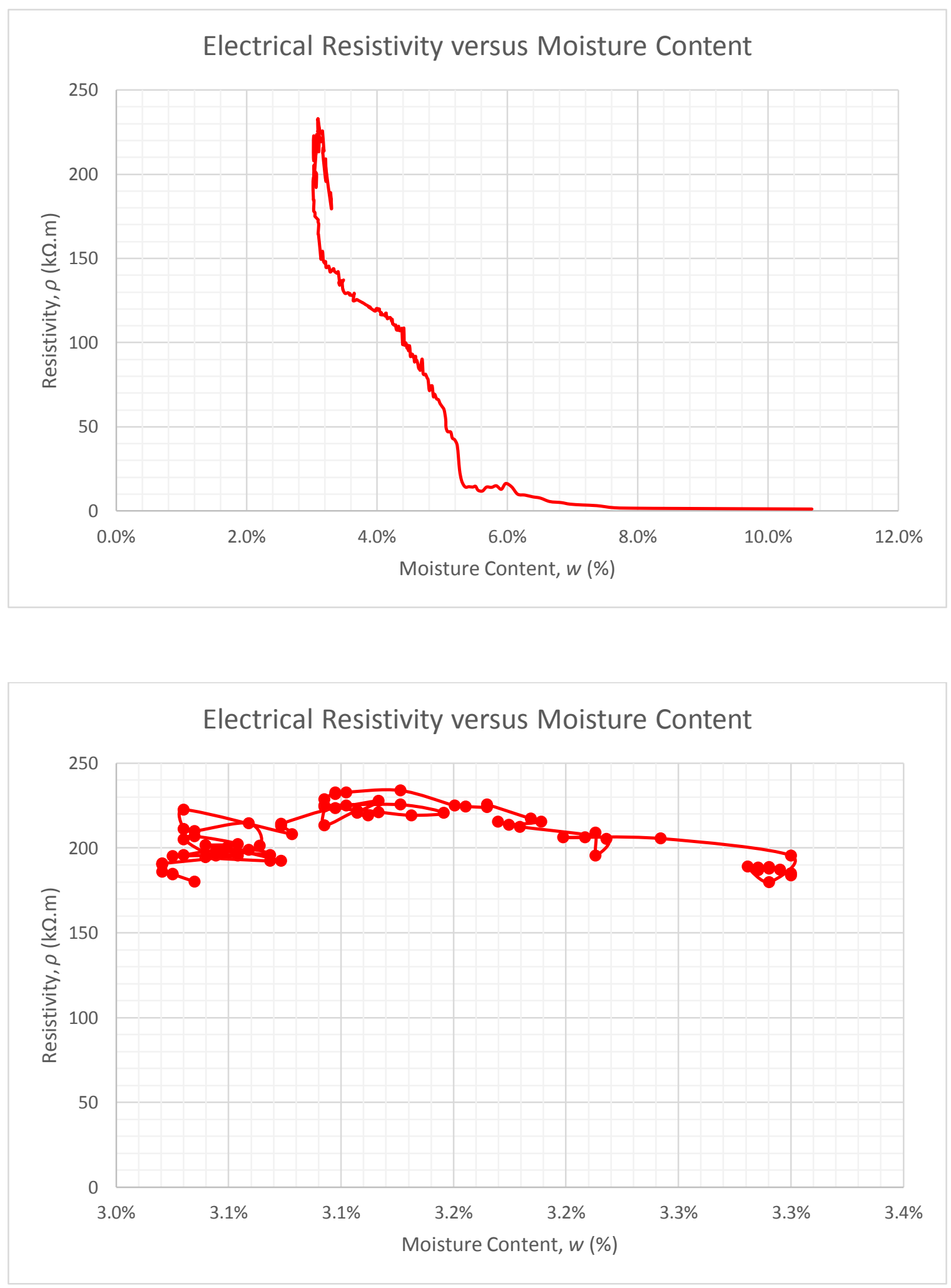

Details of electrical resistivity variation versus time, when electrical resistivity value is around $200 \mathrm{k} \Omega . \mathrm{m}$ 


\section{Data for sample R2}

\begin{tabular}{|c|c|c|c|c|c|c|}
\hline $\begin{array}{l}\text { Time } \\
\text { (Days) }\end{array}$ & $\begin{array}{l}\text { Weight, } \\
W_{\text {Total }}(\mathrm{g})\end{array}$ & $\begin{array}{c}\text { Weight, } \\
\text { W (g) }\end{array}$ & $\begin{array}{l}\text { Moisture } \\
\text { Content, w }\end{array}$ & $\begin{array}{c}\text { Density, } \\
\gamma_{\text {Moist }}\left(\mathrm{kg} / \mathrm{m}^{3}\right)\end{array}$ & $\begin{array}{l}\text { Resistance, } \\
\quad R(\mathrm{k} \Omega)\end{array}$ & $\begin{array}{c}\text { Resistivity, } \\
\rho \text { (k } \Omega . \mathrm{m})\end{array}$ \\
\hline 0 & 2597.6 & 2313.7 & 0.098 & 2280 & 1.3 & 0.2 \\
\hline 1 & 2578.2 & 2294.3 & 0.088 & 2261 & 1.9 & 0.3 \\
\hline 2 & 2571.2 & 2287.3 & 0.085 & 2254 & 2.3 & 0.3 \\
\hline 3 & 2565.5 & 2281.6 & 0.082 & 2248 & 3.5 & 0.5 \\
\hline 4 & 2559.6 & 2275.7 & 0.080 & 2242 & 5.1 & 0.8 \\
\hline 5 & 2555.5 & 2271.6 & 0.078 & 2238 & 6.1 & 0.9 \\
\hline 6 & 2552.3 & 2268.4 & 0.076 & 2235 & 7.5 & 1.1 \\
\hline 7 & 2549.0 & 2265.1 & 0.075 & 2232 & 8.2 & 1.2 \\
\hline 8 & 2545.2 & 2261.3 & 0.073 & 2228 & 9.2 & 1.4 \\
\hline 9 & 2542.2 & 2258.3 & 0.071 & 2225 & 13.4 & 2.0 \\
\hline 10 & 2539.0 & 2255.1 & 0.070 & 2222 & 18.0 & 2.7 \\
\hline 11 & 2535.5 & 2251.6 & 0.068 & 2219 & 25.5 & 3.9 \\
\hline 12 & 2532.9 & 2249.0 & 0.067 & 2216 & 32.3 & 4.9 \\
\hline 13 & 2530.9 & 2247.0 & 0.066 & 2214 & 36.9 & 5.6 \\
\hline 14 & 2528.7 & 2244.8 & 0.065 & 2212 & 44.5 & 6.8 \\
\hline 15 & 2526.5 & 2242.6 & 0.064 & 2210 & 53.7 & 8.2 \\
\hline 16 & 2524.7 & 2240.8 & 0.063 & 2208 & 57.1 & 8.7 \\
\hline 17 & 2522.8 & 2238.9 & 0.062 & 2206 & 61.5 & 9.4 \\
\hline 18 & 2520.6 & 2236.7 & 0.061 & 2204 & 96.7 & 14.7 \\
\hline 19 & 2519.3 & 2235.4 & 0.061 & 2203 & 100.4 & 15.3 \\
\hline 20 & 2517.7 & 2233.8 & 0.060 & 2201 & 105.9 & 16.1 \\
\hline 21 & 2516.3 & 2232.4 & 0.059 & 2200 & 108.1 & 16.5 \\
\hline 22 & 2514.8 & 2230.9 & 0.058 & 2198 & 110.3 & 16.8 \\
\hline 23 & 2513.4 & 2229.5 & 0.058 & 2197 & 111.3 & 17.0 \\
\hline 24 & 2512.1 & 2228.2 & 0.057 & 2196 & 114.9 & 17.5 \\
\hline 25 & 2510.8 & 2226.9 & 0.056 & 2194 & 127.8 & 19.5 \\
\hline 26 & 2509.6 & 2225.7 & 0.056 & 2193 & 131.2 & 20.0 \\
\hline 27 & 2508.7 & 2224.8 & 0.055 & 2192 & 137.9 & 21.0 \\
\hline 28 & 2507.9 & 2224.0 & 0.055 & 2191 & 120.8 & 18.4 \\
\hline 29 & 2506.7 & 2222.8 & 0.055 & 2190 & 93.5 & 14.2 \\
\hline 30 & 2505.7 & 2221.8 & 0.054 & 2189 & 126.1 & 19.2 \\
\hline 31 & 2505.0 & 2221.1 & 0.054 & 2189 & 166.6 & 25.4 \\
\hline 32 & 2504.0 & 2220.1 & 0.053 & 2188 & 209.8 & 32.0 \\
\hline 33 & 2503.5 & 2219.6 & 0.053 & 2187 & 230.5 & 35.1 \\
\hline 34 & 2502.5 & 2218.6 & 0.053 & 2186 & 270.6 & 41.2 \\
\hline 35 & 2501.8 & 2217.9 & 0.052 & 2185 & 232.9 & 35.5 \\
\hline 36 & 2501.0 & 2217.1 & 0.052 & 2185 & 295.8 & 45.1 \\
\hline 37 & 2499.8 & 2215.9 & 0.051 & 2183 & 323.5 & 49.3 \\
\hline 38 & 2499.5 & 2215.6 & 0.051 & 2183 & 341.9 & 52.1 \\
\hline
\end{tabular}




\section{Data for sample R2 (continued)}

\begin{tabular}{|c|c|c|c|c|c|c|}
\hline $\begin{array}{l}\text { Time } \\
\text { (Days) }\end{array}$ & $\begin{array}{l}\text { Weight, } \\
W_{\text {Total }} \text { (g) }\end{array}$ & $\begin{array}{c}\text { Weight, } \\
W(\mathrm{~g})\end{array}$ & $\begin{array}{l}\text { Moisture } \\
\text { Content, w }\end{array}$ & $\begin{array}{c}\text { Density, } \\
\gamma_{\text {Moist }}\left(\mathrm{kg} / \mathrm{m}^{3}\right)\end{array}$ & $\begin{array}{c}\text { Resistance, } \\
R(\mathrm{k} \Omega)\end{array}$ & $\begin{array}{c}\text { Resistivity, } \\
\rho \text { (k } \Omega . \mathrm{m})\end{array}$ \\
\hline 39 & 2498.8 & 2214.9 & 0.051 & 2182 & 340.2 & 51.8 \\
\hline 40 & 2498.2 & 2214.3 & 0.051 & 2182 & 352.2 & 53.7 \\
\hline 41 & 2497.7 & 2213.8 & 0.050 & 2181 & 363.2 & 55.4 \\
\hline 42 & 2497.2 & 2213.3 & 0.050 & 2181 & 369.5 & 56.3 \\
\hline 43 & 2496.5 & 2212.6 & 0.050 & 2180 & 406.8 & 62.0 \\
\hline 44 & 2496.0 & 2212.1 & 0.049 & 2180 & 448.6 & 68.4 \\
\hline 45 & 2495.6 & 2211.7 & 0.049 & 2179 & 438.4 & 66.8 \\
\hline 46 & 2495.1 & 2211.2 & 0.049 & 2179 & 381.6 & 58.2 \\
\hline 47 & 2494.6 & 2210.7 & 0.049 & 2178 & 388.6 & 59.2 \\
\hline 48 & 2494.1 & 2210.2 & 0.049 & 2178 & 388.2 & 59.2 \\
\hline 49 & 2493.4 & 2209.5 & 0.048 & 2177 & 382.6 & 58.3 \\
\hline 50 & 2493.1 & 2209.2 & 0.048 & 2177 & 390.8 & 59.6 \\
\hline 51 & 2492.7 & 2208.8 & 0.048 & 2176 & 392.2 & 59.8 \\
\hline 52 & 2492.3 & 2208.4 & 0.048 & 2176 & 413.6 & 63.0 \\
\hline 53 & 2491.9 & 2208.0 & 0.048 & 2176 & 436.5 & 66.5 \\
\hline 54 & 2491.0 & 2207.1 & 0.047 & 2175 & 455.8 & 69.5 \\
\hline 55 & 2490.8 & 2206.9 & 0.047 & 2175 & 479.8 & 73.1 \\
\hline 56 & 2490.2 & 2206.3 & 0.047 & 2174 & 489.9 & 74.7 \\
\hline 57 & 2490.1 & 2206.2 & 0.047 & 2174 & 503.7 & 76.8 \\
\hline 58 & 2489.7 & 2205.8 & 0.046 & 2174 & 517.4 & 78.9 \\
\hline 59 & 2489.3 & 2205.4 & 0.046 & 2173 & 522.9 & 79.7 \\
\hline 60 & 2488.9 & 2205.0 & 0.046 & 2173 & 529.8 & 80.7 \\
\hline 61 & 2488.6 & 2204.7 & 0.046 & 2172 & 544.8 & 83.0 \\
\hline 62 & 2488.3 & 2204.4 & 0.046 & 2172 & 546.8 & 83.3 \\
\hline 63 & 2487.8 & 2203.9 & 0.046 & 2172 & 550.6 & 83.9 \\
\hline 64 & 2487.4 & 2203.5 & 0.045 & 2171 & 564.6 & 86.0 \\
\hline 65 & 2487.3 & 2203.4 & 0.045 & 2171 & 574.2 & 87.5 \\
\hline 66 & 2487.0 & 2203.1 & 0.045 & 2171 & 579.8 & 88.4 \\
\hline 67 & 2486.7 & 2202.8 & 0.045 & 2171 & 585.2 & 89.2 \\
\hline 68 & 2486.5 & 2202.6 & 0.045 & 2170 & No Data & No Data \\
\hline 69 & 2486.3 & 2202.4 & 0.045 & 2170 & 592.2 & 90.3 \\
\hline 70 & 2485.9 & 2202.0 & 0.045 & 2170 & 603.4 & 92.0 \\
\hline 71 & 2485.8 & 2201.9 & 0.045 & 2170 & 611.1 & 93.1 \\
\hline 72 & 2485.6 & 2201.7 & 0.045 & 2169 & 616.8 & 94.0 \\
\hline 73 & 2485.4 & 2201.5 & 0.044 & 2169 & 621.8 & 94.8 \\
\hline 74 & 2485.0 & 2201.1 & 0.044 & 2169 & 626.2 & 95.4 \\
\hline 75 & 2484.2 & 2200.3 & 0.044 & 2168 & 638.6 & 97.3 \\
\hline 76 & 2483.9 & 2200.0 & 0.044 & 2168 & 633.8 & 96.6 \\
\hline 77 & 2483.8 & 2199.9 & 0.044 & 2168 & 637.9 & 97.2 \\
\hline
\end{tabular}




\section{Data for sample R2 (continued)}

\begin{tabular}{|c|c|c|c|c|c|c|}
\hline $\begin{array}{l}\text { Time } \\
\text { (Days) }\end{array}$ & $\begin{array}{l}\text { Weight, } \\
W_{\text {Total }} \text { (g) }\end{array}$ & $\begin{array}{c}\text { Weight, } \\
W(\mathrm{~g})\end{array}$ & $\begin{array}{l}\text { Moisture } \\
\text { Content, w }\end{array}$ & $\begin{array}{c}\text { Density, } \\
\gamma_{\text {Moist }}\left(\mathrm{kg} / \mathrm{m}^{3}\right)\end{array}$ & $\begin{array}{c}\text { Resistance, } \\
R(\mathrm{k} \Omega)\end{array}$ & $\begin{array}{c}\text { Resistivity, } \\
\rho \text { (k } \Omega . \mathrm{m})\end{array}$ \\
\hline 78 & 2483.7 & 2199.8 & 0.044 & 2168 & 643.6 & 98.1 \\
\hline 79 & 2483.3 & 2199.4 & 0.043 & 2167 & 655.2 & 99.9 \\
\hline 80 & 2483.2 & 2199.3 & 0.043 & 2167 & 658.2 & 100.3 \\
\hline 81 & 2483.1 & 2199.2 & 0.043 & 2167 & 663.8 & 101.2 \\
\hline 82 & 2482.8 & 2198.9 & 0.043 & 2167 & 698.0 & 106.4 \\
\hline 83 & 2482.9 & 2199.0 & 0.043 & 2167 & 700.0 & 106.7 \\
\hline 84 & 2482.9 & 2199.0 & 0.043 & 2167 & 704.0 & 107.3 \\
\hline 85 & 2482.3 & 2198.4 & 0.043 & 2166 & 707.0 & 107.7 \\
\hline 86 & 2482.6 & 2198.7 & 0.043 & 2167 & 711.0 & 108.4 \\
\hline 87 & 2482.5 & 2198.6 & 0.043 & 2166 & 707.0 & 107.7 \\
\hline 88 & 2481.9 & 2198.0 & 0.043 & 2166 & 715.0 & 109.0 \\
\hline 89 & 2481.4 & 2197.5 & 0.043 & 2165 & 720.0 & 109.7 \\
\hline 90 & 2480.9 & 2197.0 & 0.042 & 2165 & 712.0 & 108.5 \\
\hline 91 & 2480.9 & 2197.0 & 0.042 & 2165 & 712.0 & 108.5 \\
\hline 92 & 2480.7 & 2196.8 & 0.042 & 2165 & 710.0 & 108.2 \\
\hline 93 & 2480.4 & 2196.5 & 0.042 & 2164 & 705.0 & 107.4 \\
\hline 94 & 2480.2 & 2196.3 & 0.042 & 2164 & 714.0 & 108.8 \\
\hline 95 & 2480.1 & 2196.2 & 0.042 & 2164 & 724.0 & 110.3 \\
\hline 96 & 2479.7 & 2195.8 & 0.042 & 2164 & 733.0 & 111.7 \\
\hline 97 & 2479.1 & 2195.2 & 0.041 & 2163 & 723.0 & 110.2 \\
\hline 98 & 2479.2 & 2195.3 & 0.041 & 2163 & 727.0 & 110.8 \\
\hline 99 & 2479.2 & 2195.3 & 0.041 & 2163 & 730.0 & 111.3 \\
\hline 100 & 2478.8 & 2194.9 & 0.041 & 2163 & 732.0 & 111.6 \\
\hline 101 & 2478.5 & 2194.6 & 0.041 & 2162 & 732.0 & 111.6 \\
\hline 102 & 2478.0 & 2194.1 & 0.041 & 2162 & 730.0 & 111.3 \\
\hline 103 & 2477.3 & 2193.4 & 0.041 & 2161 & 729.0 & 111.1 \\
\hline 104 & 2476.7 & 2192.8 & 0.040 & 2161 & No Data & No Data \\
\hline 105 & 2476.2 & 2192.3 & 0.040 & 2160 & 733.0 & 111.7 \\
\hline 106 & 2476.6 & 2192.7 & 0.040 & 2161 & 741.0 & 112.9 \\
\hline 107 & 2476.6 & 2192.7 & 0.040 & 2161 & 757.0 & 115.4 \\
\hline 108 & 2476.1 & 2192.2 & 0.040 & 2160 & 755.0 & 115.1 \\
\hline 111 & 2475.0 & 2191.1 & 0.039 & 2159 & 754.0 & 114.9 \\
\hline 112 & 2474.9 & 2191.0 & 0.039 & 2159 & 756.0 & 115.2 \\
\hline 113 & 2474.6 & 2190.7 & 0.039 & 2159 & 754.0 & 114.9 \\
\hline 114 & 2474.0 & 2190.1 & 0.039 & 2158 & 747.0 & 113.8 \\
\hline 115 & 2473.7 & 2189.8 & 0.039 & 2158 & 750.0 & 114.3 \\
\hline 118 & 2472.9 & 2189.0 & 0.039 & 2157 & 756.0 & 115.2 \\
\hline 119 & 2472.2 & 2188.3 & 0.038 & 2156 & 764.0 & 116.4 \\
\hline 120 & 2471.8 & 2187.9 & 0.038 & 2156 & 762.0 & 116.1 \\
\hline
\end{tabular}




\section{Data for sample R2 (continued)}

\begin{tabular}{|c|c|c|c|c|c|c|}
\hline $\begin{array}{l}\text { Time } \\
\text { (Days) }\end{array}$ & $\begin{array}{l}\text { Weight, } \\
W_{\text {Total }}(\mathrm{g})\end{array}$ & $\begin{array}{c}\text { Weight, } \\
\text { W (g) }\end{array}$ & $\begin{array}{c}\text { Moisture } \\
\text { Content, w }\end{array}$ & $\begin{array}{c}\text { Density, } \\
\gamma_{\text {Moist }}\left(\mathrm{kg} / \mathrm{m}^{3}\right)\end{array}$ & $\begin{array}{c}\text { Resistance, } \\
R(\mathrm{k} \Omega)\end{array}$ & $\begin{array}{c}\text { Resistivity, } \\
\rho \text { (k } \Omega . \mathrm{m})\end{array}$ \\
\hline 121 & 2471.0 & 2187.1 & 0.038 & 2155 & 766.0 & 116.7 \\
\hline 122 & 2470.9 & 2187.0 & 0.038 & 2155 & 769.0 & 117.2 \\
\hline 125 & 2471.3 & 2187.4 & 0.038 & 2155 & 790.0 & 120.4 \\
\hline 126 & 2471.0 & 2187.1 & 0.038 & 2155 & 795.0 & 121.2 \\
\hline 127 & 2470.6 & 2186.7 & 0.037 & 2155 & 780.0 & 118.9 \\
\hline 129 & 2469.8 & 2185.9 & 0.037 & 2154 & 782.0 & 119.2 \\
\hline 132 & 2470.2 & 2186.3 & 0.037 & 2154 & 793.0 & 120.9 \\
\hline 133 & 2469.7 & 2185.8 & 0.037 & 2154 & 792.0 & 120.7 \\
\hline 134 & 2469.9 & 2186.0 & 0.037 & 2154 & 794.0 & 121.0 \\
\hline 135 & 2469.4 & 2185.5 & 0.037 & 2154 & 788.0 & 120.1 \\
\hline 136 & 2469.2 & 2185.3 & 0.037 & 2153 & 792.0 & 120.7 \\
\hline 139 & 2468.3 & 2184.4 & 0.036 & 2152 & 789.0 & 120.2 \\
\hline 140 & 2468.2 & 2184.3 & 0.036 & 2152 & 796.0 & 121.3 \\
\hline 142 & 2467.4 & 2183.5 & 0.036 & 2152 & 711.0 & 108.4 \\
\hline 143 & 2467.3 & 2183.4 & 0.036 & 2151 & 720.0 & 109.7 \\
\hline 146 & 2467.4 & 2183.5 & 0.036 & 2152 & 726.0 & 110.6 \\
\hline 147 & 2467.4 & 2183.5 & 0.036 & 2152 & 749.0 & 114.1 \\
\hline 148 & 2467.3 & 2183.4 & 0.036 & 2151 & 776.0 & 118.3 \\
\hline 149 & 2466.9 & 2183.0 & 0.036 & 2151 & 775.0 & 118.1 \\
\hline 150 & 2466.5 & 2182.6 & 0.035 & 2151 & 764.0 & 116.4 \\
\hline 153 & 2466.1 & 2182.2 & 0.035 & 2150 & 765.0 & 116.6 \\
\hline 154 & 2466.4 & 2182.5 & 0.035 & 2151 & 768.0 & 117.0 \\
\hline 155 & 2466.7 & 2182.8 & 0.036 & 2151 & 764.0 & 116.4 \\
\hline 157 & 2466.0 & 2182.1 & 0.035 & 2150 & 789.0 & 120.2 \\
\hline 160 & 2465.6 & 2181.7 & 0.035 & 2150 & 804.0 & 122.5 \\
\hline 161 & 2465.3 & 2181.4 & 0.035 & 2149 & 820.0 & 125.0 \\
\hline 162 & 2464.9 & 2181.0 & 0.035 & 2149 & 832.0 & 126.8 \\
\hline 164 & 2464.5 & 2180.6 & 0.035 & 2149 & 818.0 & 124.7 \\
\hline 167 & 2464.4 & 2180.5 & 0.034 & 2149 & 824.0 & 125.6 \\
\hline 168 & 2464.1 & 2180.2 & 0.034 & 2148 & 834.0 & 127.1 \\
\hline 169 & 2463.9 & 2180.0 & 0.034 & 2148 & 838.0 & 127.7 \\
\hline 171 & 2463.3 & 2179.4 & 0.034 & 2148 & 835.0 & 127.3 \\
\hline 174 & 2463.2 & 2179.3 & 0.034 & 2147 & 807.0 & 123.0 \\
\hline 175 & 2462.8 & 2178.9 & 0.034 & 2147 & 838.0 & 127.7 \\
\hline 176 & 2462.6 & 2178.7 & 0.034 & 2147 & 831.0 & 126.6 \\
\hline 177 & 2462.3 & 2178.4 & 0.033 & 2147 & 837.0 & 127.6 \\
\hline 178 & 2462.2 & 2178.3 & 0.033 & 2146 & 840.0 & 128.0 \\
\hline 181 & 2462.0 & 2178.1 & 0.033 & 2146 & 817.0 & 124.5 \\
\hline 182 & 2461.9 & 2178.0 & 0.033 & 2146 & 822.0 & 125.3 \\
\hline
\end{tabular}




\section{Data for sample R2 (continued)}

\begin{tabular}{|c|c|c|c|c|c|c|}
\hline $\begin{array}{l}\text { Time } \\
\text { (Days) }\end{array}$ & $\begin{array}{l}\text { Weight, } \\
W_{\text {Total }} \text { (g) }\end{array}$ & $\begin{array}{c}\text { Weight, } \\
\text { W (g) }\end{array}$ & $\begin{array}{l}\text { Moisture } \\
\text { Content, w }\end{array}$ & $\begin{array}{c}\text { Density, } \\
\gamma_{\text {Moist }}\left(\mathrm{kg} / \mathrm{m}^{3}\right)\end{array}$ & $\begin{array}{c}\text { Resistance, } \\
R(\mathrm{k} \Omega)\end{array}$ & $\begin{array}{c}\text { Resistivity, } \\
\rho \text { (k } \Omega . \mathrm{m})\end{array}$ \\
\hline 183 & 2461.7 & 2177.8 & 0.033 & 2146 & 830.0 & 126.5 \\
\hline 184 & 2461.3 & 2177.4 & 0.033 & 2146 & 831.0 & 126.6 \\
\hline 185 & 2461.0 & 2177.1 & 0.033 & 2145 & 842.0 & 128.3 \\
\hline 188 & 2460.7 & 2176.8 & 0.033 & 2145 & 858.0 & 130.8 \\
\hline 189 & 2460.5 & 2176.6 & 0.033 & 2145 & 864.0 & 131.7 \\
\hline 190 & 2460.1 & 2176.2 & 0.032 & 2144 & 885.0 & 134.9 \\
\hline 191 & 2460.0 & 2176.1 & 0.032 & 2144 & 882.0 & 134.4 \\
\hline 192 & 2459.9 & 2176.0 & 0.032 & 2144 & 881.0 & 134.3 \\
\hline 195 & 2459.6 & 2175.7 & 0.032 & 2144 & 890.0 & 135.6 \\
\hline 196 & 2459.2 & 2175.3 & 0.032 & 2143 & 894.0 & 136.2 \\
\hline 197 & 2459.1 & 2175.2 & 0.032 & 2143 & 912.0 & 139.0 \\
\hline 198 & 2459.1 & 2175.2 & 0.032 & 2143 & 934.0 & 142.3 \\
\hline 199 & 2458.8 & 2174.9 & 0.032 & 2143 & 930.0 & 141.7 \\
\hline 202 & 2459.0 & 2175.1 & 0.032 & 2143 & 960.0 & 146.3 \\
\hline 203 & 2458.9 & 2175.0 & 0.032 & 2143 & 968.0 & 147.5 \\
\hline 204 & 2458.9 & 2175.0 & 0.032 & 2143 & 963.0 & 146.8 \\
\hline 205 & 2458.9 & 2175.0 & 0.032 & 2143 & 990.0 & 150.9 \\
\hline 206 & 2458.5 & 2174.6 & 0.032 & 2143 & 1000.0 & 152.4 \\
\hline 209 & 2458.0 & 2174.1 & 0.031 & 2142 & 973.0 & 148.3 \\
\hline 210 & 2458.0 & 2174.1 & 0.031 & 2142 & 989.0 & 150.7 \\
\hline 211 & 2458.0 & 2174.1 & 0.031 & 2142 & 996.0 & 151.8 \\
\hline 212 & 2457.5 & 2173.6 & 0.031 & 2142 & 1005.0 & 153.2 \\
\hline 213 & 2457.4 & 2173.5 & 0.031 & 2142 & 1002.0 & 152.7 \\
\hline 216 & 2457.6 & 2173.7 & 0.031 & 2142 & 1032.0 & 157.3 \\
\hline 217 & 2457.4 & 2173.5 & 0.031 & 2142 & 1025.0 & 156.2 \\
\hline 218 & 2457.3 & 2173.4 & 0.031 & 2142 & 1026.0 & 156.4 \\
\hline 219 & 2457.2 & 2173.3 & 0.031 & 2141 & 1041.0 & 158.6 \\
\hline 220 & 2457.1 & 2173.2 & 0.031 & 2141 & 1042.0 & 158.8 \\
\hline 223 & 2457.2 & 2173.3 & 0.031 & 2141 & 1040.0 & 158.5 \\
\hline 224 & 2457.2 & 2173.3 & 0.031 & 2141 & 1050.0 & 160.0 \\
\hline 225 & 2457.7 & 2173.8 & 0.031 & 2142 & 1076.0 & 164.0 \\
\hline 227 & 2457.3 & 2173.4 & 0.031 & 2142 & 1067.0 & 162.6 \\
\hline 230 & 2457.3 & 2173.4 & 0.031 & 2142 & 1057.0 & 161.1 \\
\hline 231 & 2457.4 & 2173.5 & 0.031 & 2142 & 1086.0 & 165.5 \\
\hline 232 & 2457.9 & 2174.0 & 0.031 & 2142 & 1094.0 & 166.7 \\
\hline 233 & 2457.7 & 2173.8 & 0.031 & 2142 & 1094.0 & 166.7 \\
\hline 234 & 2457.2 & 2173.3 & 0.031 & 2141 & 1052.0 & 160.3 \\
\hline 237 & 2457.9 & 2174.0 & 0.031 & 2142 & 1051.0 & 160.2 \\
\hline 238 & 2457.9 & 2174.0 & 0.031 & 2142 & 1058.0 & 161.2 \\
\hline
\end{tabular}




\section{Data for sample R2 (continued)}

\begin{tabular}{|c|c|c|c|c|c|c|}
\hline $\begin{array}{l}\text { Time } \\
\text { (Days) }\end{array}$ & $\begin{array}{l}\text { Weight, } \\
W_{\text {Total }} \text { (g) }\end{array}$ & $\begin{array}{c}\text { Weight, } \\
W(\mathrm{~g})\end{array}$ & $\begin{array}{l}\text { Moisture } \\
\text { Content, w }\end{array}$ & $\begin{array}{c}\text { Density, } \\
\gamma_{\text {Moist }}\left(\mathrm{kg} / \mathrm{m}^{3}\right)\end{array}$ & $\begin{array}{c}\text { Resistance, } \\
R(\mathrm{k} \Omega)\end{array}$ & $\begin{array}{c}\text { Resistivity, } \\
\rho \text { (k } \Omega . \mathrm{m})\end{array}$ \\
\hline 239 & 2457.5 & 2173.6 & 0.031 & 2142 & 1084.0 & 165.2 \\
\hline 240 & 2457.3 & 2173.4 & 0.031 & 2142 & 1089.0 & 166.0 \\
\hline 241 & 2457.5 & 2173.6 & 0.031 & 2142 & 1098.0 & 167.3 \\
\hline 244 & 2457.2 & 2173.3 & 0.031 & 2141 & 1114.0 & 169.8 \\
\hline 245 & 2457.2 & 2173.3 & 0.031 & 2141 & 1109.0 & 169.0 \\
\hline 246 & 2457.3 & 2173.4 & 0.031 & 2142 & 1096.0 & 167.0 \\
\hline 247 & 2457.0 & 2173.1 & 0.031 & 2141 & 1100.0 & 167.6 \\
\hline 248 & 2457.5 & 2173.6 & 0.031 & 2142 & 1156.0 & 176.2 \\
\hline 251 & 2457.0 & 2173.1 & 0.031 & 2141 & 1128.0 & 171.9 \\
\hline 253 & 2456.9 & 2173.0 & 0.031 & 2141 & 1146.0 & 174.7 \\
\hline 254 & 2457.0 & 2173.1 & 0.031 & 2141 & 1186.0 & 180.7 \\
\hline 255 & 2457.9 & 2174.0 & 0.031 & 2142 & 1152.0 & 175.6 \\
\hline 258 & 2457.7 & 2173.8 & 0.031 & 2142 & 1153.0 & 175.7 \\
\hline 259 & 2457.7 & 2173.8 & 0.031 & 2142 & 1158.0 & 176.5 \\
\hline 260 & 2458.1 & 2174.2 & 0.031 & 2142 & 1240.0 & 189.0 \\
\hline 261 & 2458.4 & 2174.5 & 0.032 & 2143 & 1241.0 & 189.1 \\
\hline 262 & 2458.7 & 2174.8 & 0.032 & 2143 & 1242.0 & 189.3 \\
\hline 265 & 2458.3 & 2174.4 & 0.032 & 2143 & 1226.0 & 186.8 \\
\hline 266 & 2458.2 & 2174.3 & 0.032 & 2142 & 1254.0 & 191.1 \\
\hline 267 & 2458.1 & 2174.2 & 0.031 & 2142 & 1236.0 & 188.4 \\
\hline 268 & 2457.9 & 2174.0 & 0.031 & 2142 & 1228.0 & 187.1 \\
\hline 269 & 2458.6 & 2174.7 & 0.032 & 2143 & 1268.0 & 193.2 \\
\hline 272 & 2458.9 & 2175.0 & 0.032 & 2143 & 1250.0 & 190.5 \\
\hline 273 & 2458.5 & 2174.6 & 0.032 & 2143 & 1238.0 & 188.7 \\
\hline 274 & 2458.3 & 2174.4 & 0.032 & 2143 & 1211.0 & 184.6 \\
\hline 275 & 2458.1 & 2174.2 & 0.031 & 2142 & 1210.0 & 184.4 \\
\hline 276 & 2457.8 & 2173.9 & 0.031 & 2142 & 1166.0 & 177.7 \\
\hline 279 & 2457.9 & 2174.0 & 0.031 & 2142 & 1225.0 & 186.7 \\
\hline 280 & 2457.9 & 2174.0 & 0.031 & 2142 & 1244.0 & 189.6 \\
\hline 281 & 2457.9 & 2174.0 & 0.031 & 2142 & 1262.0 & 192.3 \\
\hline 282 & 2458.1 & 2174.2 & 0.031 & 2142 & 1294.0 & 197.2 \\
\hline 283 & 2458.2 & 2174.3 & 0.032 & 2142 & 1269.0 & 193.4 \\
\hline 286 & 2458.7 & 2174.8 & 0.032 & 2143 & 1294.0 & 197.2 \\
\hline 287 & 2458.7 & 2174.8 & 0.032 & 2143 & 1293.0 & 197.1 \\
\hline 288 & 2458.8 & 2174.9 & 0.032 & 2143 & 1294.0 & 197.2 \\
\hline 289 & 2459.0 & 2175.1 & 0.032 & 2143 & 1287.0 & 196.1 \\
\hline 290 & 2459.1 & 2175.2 & 0.032 & 2143 & 1294.0 & 197.2 \\
\hline 293 & 2459.3 & 2175.4 & 0.032 & 2144 & 1264.0 & 192.6 \\
\hline 294 & 2459.3 & 2175.4 & 0.032 & 2144 & 1256.0 & 191.4 \\
\hline
\end{tabular}




\section{Data for sample R2 (continued)}

\begin{tabular}{|c|c|c|c|c|c|c|}
\hline $\begin{array}{l}\text { Time } \\
\text { (Days) }\end{array}$ & $\begin{array}{l}\text { Weight, } \\
W_{\text {Total }}(\mathrm{g})\end{array}$ & $\begin{array}{c}\text { Weight, } \\
W(\mathrm{~g})\end{array}$ & $\begin{array}{c}\text { Moisture } \\
\text { Content, w }\end{array}$ & $\begin{array}{c}\text { Density, } \\
\gamma_{\text {Moist }}\left(\mathrm{kg} / \mathrm{m}^{3}\right)\end{array}$ & $\begin{array}{c}\text { Resistance, } \\
R(\mathrm{k} \Omega)\end{array}$ & $\begin{array}{c}\text { Resistivity, } \\
\rho \text { (k } \Omega . \mathrm{m})\end{array}$ \\
\hline 295 & 2459.2 & 2175.3 & 0.032 & 2143 & 1216.0 & 185.3 \\
\hline 296 & 2459.1 & 2175.2 & 0.032 & 2143 & 1228.0 & 187.1 \\
\hline 297 & 2459.3 & 2175.4 & 0.032 & 2144 & 1246.0 & 189.9 \\
\hline 300 & 2460.0 & 2176.1 & 0.032 & 2144 & 1228.0 & 187.1 \\
\hline 301 & 2459.9 & 2176.0 & 0.032 & 2144 & 1236.0 & 188.4 \\
\hline 302 & 2459.8 & 2175.9 & 0.032 & 2144 & 1236.0 & 188.4 \\
\hline 303 & 2459.5 & 2175.6 & 0.032 & 2144 & 1236.0 & 188.4 \\
\hline 304 & 2459.5 & 2175.6 & 0.032 & 2144 & 1206.0 & 183.8 \\
\hline 311 & 2460.4 & 2176.5 & 0.033 & 2145 & 1224.0 & 186.5 \\
\hline 318 & 2461.2 & 2177.3 & 0.033 & 2145 & 1211.0 & 184.6 \\
\hline 321 & 2461.0 & 2177.1 & 0.033 & 2145 & 1082.0 & 164.9 \\
\hline 323 & 2461.0 & 2177.1 & 0.033 & 2145 & 1132.0 & 172.5 \\
\hline 325 & 2461.0 & 2177.1 & 0.033 & 2145 & 1142.0 & 174.0 \\
\hline 328 & 2461.1 & 2177.2 & 0.033 & 2145 & 1151.0 & 175.4 \\
\hline 330 & 2461.1 & 2177.2 & 0.033 & 2145 & 1130.0 & 172.2 \\
\hline 331 & 2461.1 & 2177.2 & 0.033 & 2145 & 1144.0 & 174.3 \\
\hline 332 & 2461.1 & 2177.2 & 0.033 & 2145 & 1139.0 & 173.6 \\
\hline 335 & 2461.1 & 2177.2 & 0.033 & 2145 & 1131.0 & 172.4 \\
\hline 336 & 2461.1 & 2177.2 & 0.033 & 2145 & 1128.0 & 171.9 \\
\hline 339 & 2461.1 & 2177.2 & 0.033 & 2145 & 1137.0 & 173.3 \\
\hline 346 & 2461.1 & 2177.2 & 0.033 & 2145 & 1122.0 & 171.0 \\
\hline 350 & 2461.3 & 2177.4 & 0.033 & 2146 & 1136.0 & 173.1 \\
\hline 353 & 2461.3 & 2177.4 & 0.033 & 2146 & 1121.0 & 170.8 \\
\hline 356 & 2461.4 & 2177.5 & 0.033 & 2146 & 1134.0 & 172.8 \\
\hline 358 & 2461.3 & 2177.4 & 0.033 & 2146 & 1130.0 & 172.2 \\
\hline 360 & 2461.3 & 2177.4 & 0.033 & 2146 & 1120.0 & 170.7 \\
\hline 363 & 2461.3 & 2177.4 & 0.033 & 2146 & 1122.0 & 171.0 \\
\hline 365 & 2461.3 & 2177.4 & 0.033 & 2146 & 1126.0 & 171.6 \\
\hline
\end{tabular}




\section{Electrical resistivity and moisture content plots for sample R2}
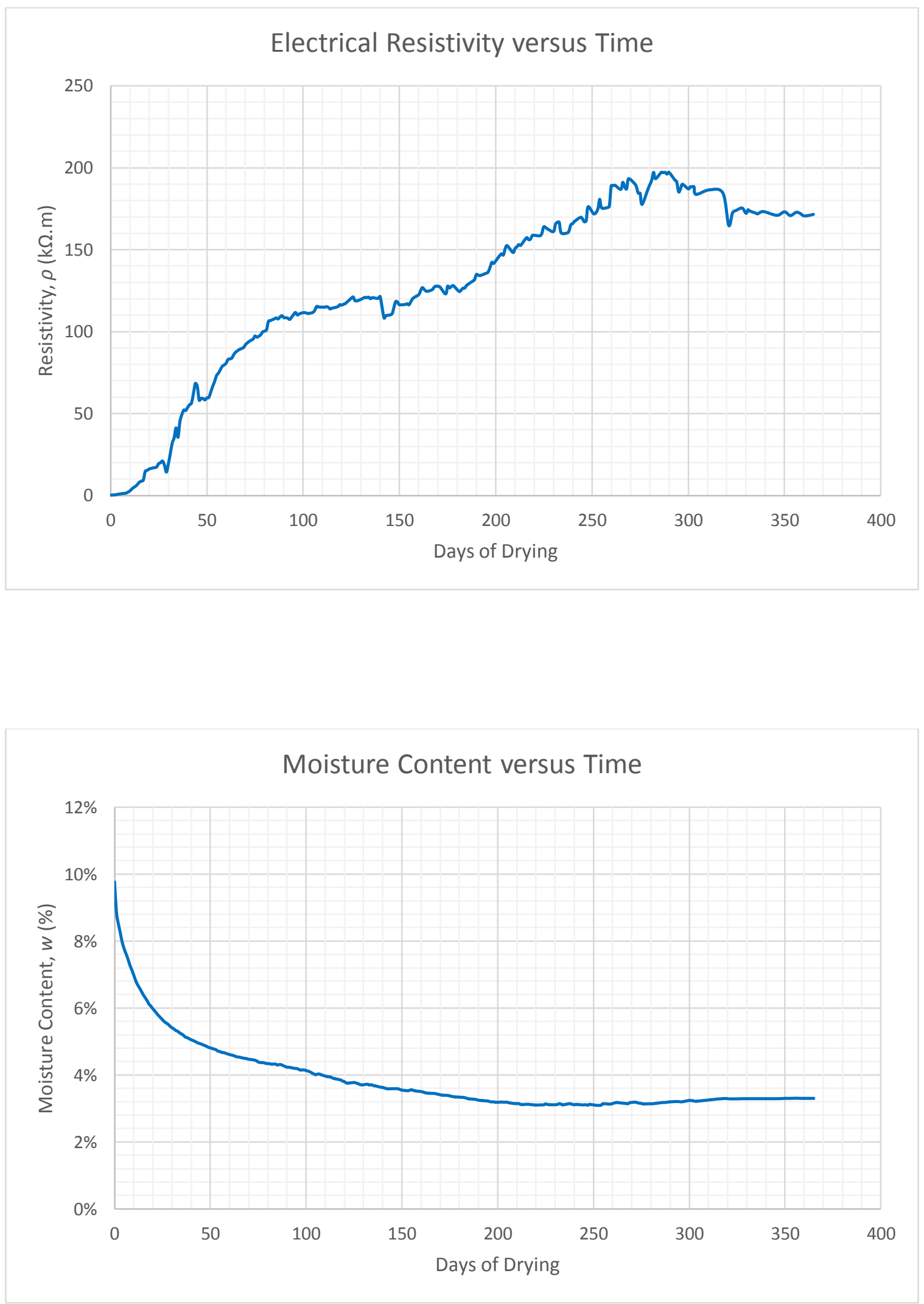


\section{Electrical resistivity plots for sample $\mathbf{R 2}$}
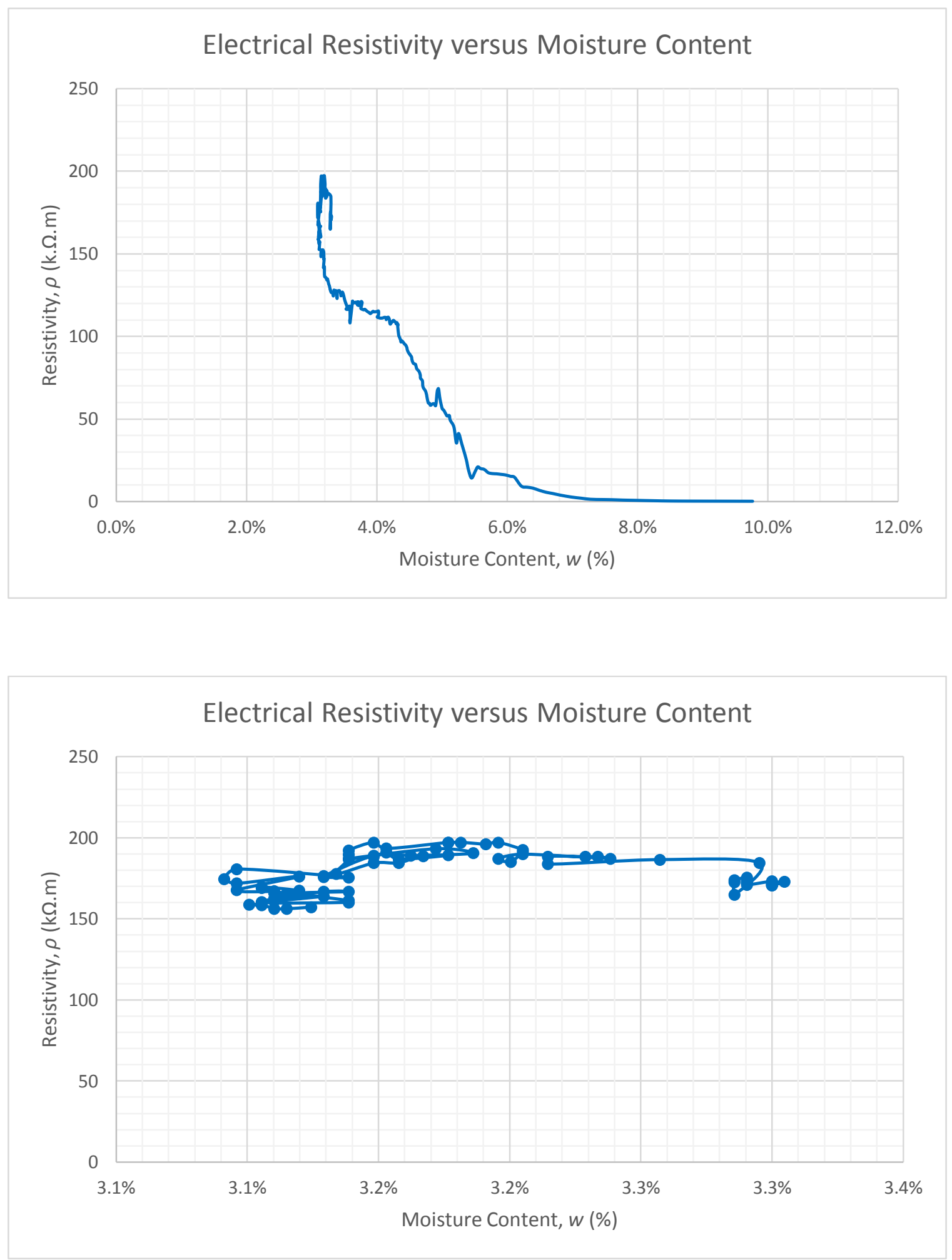

Details of electrical resistivity variation versus time, when electrical resistivity value is around $200 \mathrm{k} \Omega . \mathrm{m}$ 


\section{Data for sample T-H1}

\begin{tabular}{|c|c|c|c|c|c|c|c|}
\hline \multirow{2}{*}{$\begin{array}{l}\text { Time } \\
\text { (Days) }\end{array}$} & \multirow{2}{*}{$\begin{array}{l}\text { Weight, } \\
W_{\text {Total }}(\mathrm{g})\end{array}$} & \multirow{2}{*}{$\begin{array}{c}\text { Weight, } \\
W(\mathrm{~g})\end{array}$} & \multirow{2}{*}{$\begin{array}{l}\text { Moisture } \\
\text { Content, } w\end{array}$} & \multirow{2}{*}{$\begin{array}{c}\text { Density, } \gamma_{\text {Moist }} \\
\left(\mathrm{kg} / \mathrm{m}^{3}\right)\end{array}$} & \multicolumn{2}{|c|}{ Temperature } & \multirow{2}{*}{$\begin{array}{l}\text { Rel. Humidity, } \\
\text { RH (\%) }\end{array}$} \\
\hline & & & & & ${ }^{\circ} \mathrm{C}$ & ${ }^{\circ} \mathrm{F}$ & \\
\hline 0 & 2537.3 & 2461.1 & 0.095 & 2416 & 23.11 & 73.70 & 99.99 \\
\hline 1 & 2503.4 & 2427.2 & 0.080 & 2383 & 22.34 & 72.28 & 99.99 \\
\hline 2 & 2492.9 & 2416.7 & 0.075 & 2373 & 22.72 & 73.00 & 99.99 \\
\hline 3 & 2486.5 & 2410.3 & 0.072 & 2366 & 22.56 & 72.66 & 99.99 \\
\hline 4 & 2481.6 & 2405.4 & 0.070 & 2361 & 22.59 & 72.73 & 99.99 \\
\hline 5 & 2477.4 & 2401.2 & 0.068 & 2357 & 22.39 & 72.35 & 99.99 \\
\hline 6 & 2473.8 & 2397.6 & 0.067 & 2354 & 22.69 & 72.89 & 99.99 \\
\hline 7 & 2471.5 & 2395.3 & 0.066 & 2352 & 24.50 & 76.20 & 99.99 \\
\hline 8 & 2468.6 & 2392.4 & 0.064 & 2349 & 24.72 & 76.53 & 99.99 \\
\hline 9 & 2466.0 & 2389.8 & 0.063 & 2346 & 23.68 & 74.69 & 99.99 \\
\hline 10 & 2463.8 & 2387.6 & 0.062 & 2344 & 23.10 & 73.65 & 99.99 \\
\hline 11 & 2461.7 & 2385.5 & 0.061 & 2342 & 22.64 & 72.84 & 99.99 \\
\hline 12 & 2459.6 & 2383.4 & 0.060 & 2340 & 22.58 & 72.72 & 99.99 \\
\hline 13 & 2458.1 & 2381.9 & 0.060 & 2338 & 22.53 & 72.57 & 99.99 \\
\hline 14 & 2456.6 & 2380.4 & 0.059 & 2337 & 23.36 & 74.12 & 99.99 \\
\hline 15 & 2455.5 & 2379.3 & 0.058 & 2336 & 23.50 & 74.37 & 99.99 \\
\hline 16 & 2454.0 & 2377.8 & 0.058 & 2334 & 22.85 & 73.20 & 99.99 \\
\hline 17 & 2452.6 & 2376.4 & 0.057 & 2333 & 23.20 & 73.83 & 99.99 \\
\hline 18 & 2451.4 & 2375.2 & 0.057 & 2332 & 23.46 & 74.30 & 99.99 \\
\hline 19 & 2450.3 & 2374.1 & 0.056 & 2331 & 22.68 & 72.90 & 99.99 \\
\hline 20 & 2449.0 & 2372.8 & 0.056 & 2329 & 23.07 & 73.61 & 99.99 \\
\hline 21 & 2448.4 & 2372.2 & 0.055 & 2329 & 23.72 & 74.44 & 99.99 \\
\hline 22 & 2447.3 & 2371.1 & 0.055 & 2328 & 22.95 & 73.40 & 99.99 \\
\hline 23 & 2446.6 & 2370.4 & 0.054 & 2327 & 23.15 & 73.74 & 99.99 \\
\hline 24 & 2445.5 & 2369.3 & 0.054 & 2326 & 23.25 & 73.92 & 99.99 \\
\hline 25 & 2444.8 & 2368.6 & 0.054 & 2325 & 22.72 & 72.97 & 99.99 \\
\hline 26 & 2444.2 & 2368.0 & 0.053 & 2325 & \multicolumn{2}{|c|}{ No Data } & 99.99 \\
\hline 27 & 2443.5 & 2367.3 & 0.053 & 2324 & \multicolumn{2}{|c|}{ No Data } & 99.99 \\
\hline 28 & 2442.9 & 2366.7 & 0.053 & 2323 & 24.56 & 76.28 & 99.99 \\
\hline 29 & 2442.1 & 2365.9 & 0.052 & 2323 & 23.69 & 74.73 & 99.99 \\
\hline 30 & 2441.4 & 2365.2 & 0.052 & 2322 & 23.12 & 73.71 & 99.99 \\
\hline 31 & 2440.9 & 2364.7 & 0.052 & 2322 & 22.58 & 72.72 & 99.62 \\
\hline 32 & 2440.0 & 2363.8 & 0.052 & 2321 & 23.35 & 74.10 & 99.35 \\
\hline 33 & 2439.5 & 2363.3 & 0.051 & 2320 & 23.16 & 73.56 & 98.91 \\
\hline 34 & 2439.5 & 2363.3 & 0.051 & 2320 & 23.52 & 74.37 & 98.57 \\
\hline 35 & 2439.1 & 2362.9 & 0.051 & 2320 & 22.70 & 72.95 & 98.17 \\
\hline 36 & 2438.5 & 2362.3 & 0.051 & 2319 & 22.81 & 73.15 & 97.72 \\
\hline 37 & 2437.7 & 2361.5 & 0.050 & 2318 & 22.56 & 72.68 & 97.34 \\
\hline 38 & 2437.2 & 2361.0 & 0.050 & 2318 & 22.74 & 73.00 & 96.94 \\
\hline
\end{tabular}




\section{Data for sample T-H1 (continued)}

\begin{tabular}{|c|c|c|c|c|c|c|c|}
\hline \multirow{2}{*}{$\begin{array}{c}\text { Time } \\
\text { (Days) }\end{array}$} & \multirow{2}{*}{$\begin{array}{l}\text { Weight, } \\
W_{\text {Total }} \text { (g) }\end{array}$} & \multirow{2}{*}{$\begin{array}{c}\text { Weight, } \\
\text { W (g) }\end{array}$} & \multirow{2}{*}{$\begin{array}{l}\text { Moisture } \\
\text { Content, } w\end{array}$} & \multirow{2}{*}{$\begin{array}{c}\text { Density, } \gamma_{\text {Moist }} \\
\left(\mathrm{kg} / \mathrm{m}^{3}\right)\end{array}$} & \multicolumn{2}{|c|}{ Temperature } & \multirow{2}{*}{$\begin{array}{c}\text { Rel. Humidity, } \\
\text { RH (\%) }\end{array}$} \\
\hline & & & & & ${ }^{\circ} \mathrm{C}$ & ${ }^{\circ} \mathrm{F}$ & \\
\hline 39 & 2436.5 & 2360.3 & 0.050 & 2317 & 22.42 & 72.41 & 96.59 \\
\hline 40 & 2436.1 & 2359.9 & 0.050 & 2317 & 22.64 & 72.84 & 96.16 \\
\hline 41 & 2435.6 & 2359.4 & 0.050 & 2316 & 22.59 & 72.75 & 95.74 \\
\hline 42 & 2435.3 & 2359.1 & 0.049 & 2316 & 23.27 & 73.94 & 95.51 \\
\hline 43 & 2434.9 & 2358.7 & 0.049 & 2316 & 22.92 & 73.33 & 95.10 \\
\hline 44 & 2434.3 & 2358.1 & 0.049 & 2315 & 22.94 & 73.36 & 94.70 \\
\hline 45 & 2433.8 & 2357.6 & 0.049 & 2315 & 22.84 & 73.18 & 94.40 \\
\hline 46 & 2433.6 & 2357.4 & 0.049 & 2314 & 23.13 & 73.72 & 94.06 \\
\hline 47 & 2433.0 & 2356.8 & 0.048 & 2314 & 22.61 & 72.79 & 93.42 \\
\hline 48 & 2432.8 & 2356.6 & 0.048 & 2314 & 22.64 & 72.82 & 93.10 \\
\hline 49 & 2432.5 & 2356.3 & 0.048 & 2313 & 23.25 & 73.90 & 92.79 \\
\hline 50 & 2432.0 & 2355.8 & 0.048 & 2313 & 23.13 & 73.71 & 92.43 \\
\hline 51 & 2431.8 & 2355.6 & 0.048 & 2313 & 22.59 & 72.77 & 91.92 \\
\hline 52 & 2431.4 & 2355.2 & 0.048 & 2312 & 23.09 & 73.63 & 91.67 \\
\hline 53 & 2430.9 & 2354.7 & 0.047 & 2312 & 23.46 & 74.30 & 91.29 \\
\hline 54 & 2430.6 & 2354.4 & 0.047 & 2311 & 22.96 & 73.40 & 90.79 \\
\hline 55 & 2430.4 & 2354.2 & 0.047 & 2311 & 23.16 & 73.16 & 90.50 \\
\hline 56 & 2430.1 & 2353.9 & 0.047 & 2311 & 23.40 & 74.19 & 90.27 \\
\hline 57 & 2429.7 & 2353.5 & 0.047 & 2311 & 22.97 & 73.44 & 89.83 \\
\hline 58 & 2429.5 & 2353.3 & 0.047 & 2310 & 23.31 & 74.03 & 89.53 \\
\hline 59 & 2429.3 & 2353.1 & 0.047 & 2310 & 22.98 & 73.45 & 89.11 \\
\hline 60 & 2429.0 & 2352.8 & 0.047 & 2310 & 23.00 & 73.47 & 88.88 \\
\hline 61 & 2428.7 & 2352.5 & 0.046 & 2310 & 23.44 & 74.26 & 88.69 \\
\hline 62 & 2428.5 & 2352.3 & 0.046 & 2309 & 23.22 & 73.87 & 88.39 \\
\hline 63 & 2428.2 & 2352.0 & 0.046 & 2309 & 22.97 & 73.42 & 88.04 \\
\hline 64 & 2427.9 & 2351.7 & 0.046 & 2309 & 22.96 & 73.42 & 87.70 \\
\hline 65 & 2427.6 & 2351.4 & 0.046 & 2308 & 23.46 & 74.30 & 87.57 \\
\hline 66 & 2427.4 & 2351.2 & 0.046 & 2308 & 22.77 & 73.06 & 87.11 \\
\hline 67 & 2427.2 & 2351.0 & 0.046 & 2308 & 22.66 & 72.86 & 86.84 \\
\hline 68 & 2426.9 & 2350.7 & 0.046 & 2308 & 23.06 & 73.56 & 86.61 \\
\hline 69 & 2426.7 & 2350.5 & 0.046 & 2308 & 22.94 & 73.35 & 86.21 \\
\hline 70 & 2426.5 & 2350.3 & 0.045 & 2307 & 23.21 & 73.87 & 86.05 \\
\hline 71 & 2426.3 & 2350.1 & 0.045 & 2307 & 23.27 & 73.96 & 85.79 \\
\hline 72 & 2426.0 & 2349.8 & 0.045 & 2307 & 23.27 & 73.94 & 85.39 \\
\hline 73 & 2426.6 & 2350.4 & 0.046 & 2307 & 22.78 & 73.04 & 84.98 \\
\hline 74 & 2425.7 & 2349.5 & 0.045 & 2307 & 23.54 & 74.44 & 85.00 \\
\hline 75 & 2425.5 & 2349.3 & 0.045 & 2306 & 23.62 & 74.59 & 84.61 \\
\hline 76 & 2425.2 & 2349.0 & 0.045 & 2306 & 22.75 & 73.04 & 84.04 \\
\hline 77 & 2425.1 & 2348.9 & 0.045 & 2306 & 23.50 & 74.39 & 83.95 \\
\hline
\end{tabular}




\section{Data for sample T-H1 (continued)}

\begin{tabular}{|c|c|c|c|c|c|c|c|}
\hline \multirow{2}{*}{$\begin{array}{l}\text { Time } \\
\text { (Days) }\end{array}$} & \multirow{2}{*}{$\begin{array}{l}\text { Weight, } \\
W_{\text {Total }}(\mathrm{g})\end{array}$} & \multirow{2}{*}{$\begin{array}{l}\text { Weight, } \\
\text { W (g) }\end{array}$} & \multirow{2}{*}{$\begin{array}{c}\text { Moisture } \\
\text { Content, } w\end{array}$} & \multirow{2}{*}{$\begin{array}{c}\text { Density, } \gamma_{\text {Moist }} \\
\left(\mathrm{kg} / \mathrm{m}^{3}\right)\end{array}$} & \multicolumn{2}{|c|}{ Temperature } & \multirow{2}{*}{$\begin{array}{c}\text { Rel. Humidity, } \\
\text { RH (\%) }\end{array}$} \\
\hline & & & & & ${ }^{\circ} \mathrm{C}$ & ${ }^{\circ} \mathrm{F}$ & \\
\hline 78 & 2424.8 & 2348.6 & 0.045 & 2306 & 23.40 & 74.19 & 83.63 \\
\hline 79 & 2424.7 & 2348.5 & 0.045 & 2306 & 23.56 & 74.50 & 83.38 \\
\hline 80 & 2424.5 & 2348.3 & 0.045 & 2305 & 23.22 & 73.87 & 83.02 \\
\hline 81 & 2424.2 & 2348.0 & 0.044 & 2305 & 23.50 & 74.39 & 82.57 \\
\hline 82 & 2424.0 & 2347.8 & 0.044 & 2305 & 23.44 & 74.21 & 82.35 \\
\hline 83 & 2423.7 & 2347.5 & 0.044 & 2305 & 23.39 & 74.17 & 81.98 \\
\hline 84 & 2423.3 & 2347.1 & 0.044 & 2304 & 24.13 & 75.52 & 81.88 \\
\hline 85 & 2423.2 & 2347.0 & 0.044 & 2304 & 23.00 & 73.58 & 81.35 \\
\hline 86 & 2423.0 & 2346.8 & 0.044 & 2304 & 23.62 & 74.55 & 81.28 \\
\hline 87 & 2422.7 & 2346.5 & 0.044 & 2304 & 23.38 & 74.16 & 80.84 \\
\hline 88 & 2422.5 & 2346.3 & 0.044 & 2303 & 23.02 & 73.51 & 80.40 \\
\hline 89 & 2422.3 & 2346.1 & 0.044 & 2303 & 23.56 & 74.44 & 80.33 \\
\hline 90 & 2422.2 & 2346.0 & 0.044 & 2303 & 22.74 & 73.00 & 79.73 \\
\hline 91 & 2422.1 & 2345.9 & 0.044 & 2303 & 23.16 & 73.76 & 79.58 \\
\hline 92 & 2421.7 & 2345.5 & 0.043 & 2303 & 23.20 & 73.83 & 79.25 \\
\hline 93 & 2421.5 & 2345.3 & 0.043 & 2302 & 23.32 & 74.01 & 79.01 \\
\hline 94 & 2421.5 & 2345.3 & 0.043 & 2302 & 24.27 & 75.76 & 79.05 \\
\hline 95 & 2421.2 & 2345.0 & 0.043 & 2302 & 23.86 & 75.04 & 78.70 \\
\hline 96 & 2421.2 & 2345.0 & 0.043 & 2302 & 23.09 & 73.62 & 78.17 \\
\hline 97 & 2421.0 & 2344.8 & 0.043 & 2302 & \multicolumn{2}{|c|}{ No Data } & 78.01 \\
\hline 98 & 2420.9 & 2344.7 & 0.043 & 2302 & 23.62 & 74.57 & 77.85 \\
\hline 99 & 2420.7 & 2344.5 & 0.043 & 2302 & 23.30 & 74.01 & 77.57 \\
\hline 100 & 2420.6 & 2344.4 & 0.043 & 2302 & 22.99 & 73.44 & 77.21 \\
\hline 101 & 2420.5 & 2344.3 & 0.043 & 2301 & 23.40 & 74.17 & 77.16 \\
\hline 102 & 2420.5 & 2344.3 & 0.043 & 2301 & 23.45 & 74.28 & 76.96 \\
\hline 103 & 2420.0 & 2343.8 & 0.043 & 2301 & 22.50 & 72.57 & 76.23 \\
\hline 104 & 2419.3 & 2343.1 & 0.042 & 2300 & 22.68 & 72.90 & 75.64 \\
\hline 105 & 2419.2 & 2343.0 & 0.042 & 2300 & 23.62 & 74.59 & 75.86 \\
\hline 106 & 2419.2 & 2343.0 & 0.042 & 2300 & 22.48 & 72.48 & 75.54 \\
\hline 107 & 2419.1 & 2342.9 & 0.042 & 2300 & 22.70 & 72.90 & 75.13 \\
\hline 108 & 2418.9 & 2342.7 & 0.042 & 2300 & 22.60 & 72.75 & 74.84 \\
\hline 109 & 2418.8 & 2342.6 & 0.042 & 2300 & 22.42 & 72.43 & 74.64 \\
\hline 110 & 2418.6 & 2342.4 & 0.042 & 2300 & 22.45 & 72.12 & 74.24 \\
\hline 111 & 2418.4 & 2342.2 & 0.042 & 2299 & 22.41 & 72.43 & 74.04 \\
\hline 112 & 2418.5 & 2342.3 & 0.042 & 2300 & 23.02 & 73.53 & 74.38 \\
\hline 113 & 2418.7 & 2342.5 & 0.042 & 2300 & 22.96 & 73.40 & 74.31 \\
\hline 114 & 2418.4 & 2342.2 & 0.042 & 2299 & 23.14 & 73.71 & 74.29 \\
\hline 115 & 2418.5 & 2342.3 & 0.042 & 2300 & 22.98 & 73.44 & 74.01 \\
\hline 116 & 2418.3 & 2342.1 & 0.042 & 2299 & 23.00 & 73.49 & 73.88 \\
\hline
\end{tabular}




\section{Data for sample T-H1 (continued)}

\begin{tabular}{|c|c|c|c|c|c|c|c|}
\hline \multirow{2}{*}{$\begin{array}{l}\text { Time } \\
\text { (Days) }\end{array}$} & \multirow{2}{*}{$\begin{array}{l}\text { Weight, } \\
W_{\text {Total }} \text { (g) }\end{array}$} & \multirow{2}{*}{$\begin{array}{l}\text { Weight, } \\
W(\mathrm{~g})\end{array}$} & \multirow{2}{*}{$\begin{array}{c}\text { Moisture } \\
\text { Content, } w\end{array}$} & \multirow{2}{*}{$\begin{array}{c}\text { Density, } \gamma_{\text {Moist }} \\
\left(\mathrm{kg} / \mathrm{m}^{3}\right)\end{array}$} & \multicolumn{2}{|c|}{ Temperature } & \multirow{2}{*}{$\begin{array}{l}\text { Rel. Humidity, } \\
\text { RH (\%) }\end{array}$} \\
\hline & & & & & ${ }^{\circ} \mathrm{C}$ & ${ }^{\circ} \mathrm{F}$ & \\
\hline 117 & 2418.7 & 2342.5 & 0.042 & 2300 & 22.46 & 72.41 & 73.40 \\
\hline 118 & 2417.3 & 2341.1 & 0.041 & 2298 & 22.86 & 73.22 & 72.91 \\
\hline 119 & 2417.0 & 2340.8 & 0.041 & 2298 & 23.68 & 74.70 & 72.85 \\
\hline 120 & 2417.2 & 2341.0 & 0.041 & 2298 & 22.09 & 71.82 & 72.24 \\
\hline 121 & 2417.0 & 2340.8 & 0.041 & 2298 & 22.84 & 73.21 & 72.23 \\
\hline 122 & 2416.7 & 2340.5 & 0.041 & 2298 & 23.79 & 74.91 & 72.20 \\
\hline 123 & 2416.5 & 2340.3 & 0.041 & 2298 & 23.58 & 74.50 & 71.88 \\
\hline 124 & 2416.5 & 2340.3 & 0.041 & 2298 & 22.42 & 72.43 & 71.11 \\
\hline 125 & 2416.0 & 2339.8 & 0.041 & 2297 & 22.26 & 72.14 & 70.60 \\
\hline 126 & 2415.6 & 2339.4 & 0.041 & 2297 & 23.43 & 74.25 & 70.59 \\
\hline 127 & 2415.9 & 2339.7 & 0.041 & 2297 & 23.03 & 73.51 & 70.66 \\
\hline 128 & 2415.9 & 2339.7 & 0.041 & 2297 & 21.97 & 71.60 & 70.15 \\
\hline 129 & 2415.3 & 2339.1 & 0.041 & 2296 & 23.82 & 74.93 & 70.18 \\
\hline 130 & 2415.0 & 2338.8 & 0.040 & 2296 & 22.46 & 72.50 & 69.25 \\
\hline 131 & 2414.7 & 2338.5 & 0.040 & 2296 & 23.68 & 74.70 & 69.45 \\
\hline 132 & 2413.8 & 2337.6 & 0.040 & 2295 & 23.98 & 75.22 & 68.92 \\
\hline 133 & 2413.3 & 2337.1 & 0.040 & 2294 & \multicolumn{2}{|c|}{ No Data } & No Data \\
\hline 134 & 2412.9 & 2336.7 & 0.039 & 2294 & 21.70 & 71.10 & 67.18 \\
\hline 135 & 2413.2 & 2337.0 & 0.040 & 2294 & 23.02 & 73.53 & 67.62 \\
\hline 136 & 2413.3 & 2337.1 & 0.040 & 2294 & 22.58 & 72.70 & 67.63 \\
\hline 137 & 2412.8 & 2336.6 & 0.039 & 2294 & 24.74 & 76.59 & 67.89 \\
\hline 140 & 2411.7 & 2335.5 & 0.039 & 2293 & 23.10 & 73.63 & 66.01 \\
\hline 141 & 2411.5 & 2335.3 & 0.039 & 2293 & 22.68 & 72.88 & 65.53 \\
\hline 142 & 2411.2 & 2335.0 & 0.039 & 2292 & 24.19 & 75.61 & 65.76 \\
\hline 143 & 2410.7 & 2334.5 & 0.038 & 2292 & 23.64 & 74.61 & 64.96 \\
\hline 144 & 2410.2 & 2334.0 & 0.038 & 2291 & 23.55 & 74.46 & 64.33 \\
\hline 147 & 2409.5 & 2333.3 & 0.038 & 2291 & 23.82 & 74.95 & 63.70 \\
\hline 148 & 2408.8 & 2332.6 & 0.038 & 2290 & 23.68 & 74.70 & 62.73 \\
\hline 149 & 2408.3 & 2332.1 & 0.037 & 2289 & 23.19 & 73.83 & 61.99 \\
\hline 150 & 2407.8 & 2331.6 & 0.037 & 2289 & 23.77 & 74.86 & 61.90 \\
\hline 151 & 2407.5 & 2331.3 & 0.037 & 2289 & 23.34 & 74.08 & 61.21 \\
\hline 154 & 2408.0 & 2331.8 & 0.037 & 2289 & 22.52 & 72.61 & 61.11 \\
\hline 155 & 2407.6 & 2331.4 & 0.037 & 2289 & 23.09 & 73.62 & 60.78 \\
\hline 156 & 2407.3 & 2331.1 & 0.037 & 2289 & 24.04 & 75.34 & 60.63 \\
\hline 158 & 2406.5 & 2330.3 & 0.037 & 2288 & 23.52 & 74.44 & 59.61 \\
\hline 161 & 2406.8 & 2330.6 & 0.037 & 2288 & 23.59 & 74.52 & 59.83 \\
\hline 162 & 2406.6 & 2330.4 & 0.037 & 2288 & 24.75 & 76.60 & 59.52 \\
\hline 163 & 2406.5 & 2330.3 & 0.037 & 2288 & 24.40 & 75.99 & 59.68 \\
\hline 164 & 2406.1 & 2329.9 & 0.036 & 2287 & 24.68 & 76.50 & 59.15 \\
\hline
\end{tabular}




\section{Data for sample T-H1 (continued)}

\begin{tabular}{|c|c|c|c|c|c|c|c|}
\hline \multirow{2}{*}{$\begin{array}{c}\text { Time } \\
\text { (Days) }\end{array}$} & \multirow{2}{*}{$\begin{array}{l}\text { Weight, } \\
W_{\text {Total }}(\mathrm{g})\end{array}$} & \multirow{2}{*}{$\begin{array}{l}\text { Weight, } \\
W(\mathrm{~g})\end{array}$} & \multirow{2}{*}{$\begin{array}{l}\text { Moisture } \\
\text { Content, } w\end{array}$} & \multirow{2}{*}{$\begin{array}{c}\text { Density, YMoist } \\
\left(\mathrm{kg} / \mathrm{m}^{3}\right)\end{array}$} & \multicolumn{2}{|c|}{ Temperature } & \multirow{2}{*}{$\begin{array}{l}\text { Rel. Humidity, } \\
\text { RH (\%) }\end{array}$} \\
\hline & & & & & ${ }^{\circ} \mathrm{C}$ & ${ }^{\circ} \mathrm{F}$ & \\
\hline 165 & 2406.0 & 2329.8 & 0.036 & 2287 & 25.00 & 77.09 & 59.17 \\
\hline 168 & 2404.9 & 2328.7 & 0.036 & 2286 & 25.36 & 77.72 & 58.27 \\
\hline 169 & 2404.9 & 2328.7 & 0.036 & 2286 & 24.68 & 76.48 & 57.83 \\
\hline 171 & 2404.1 & 2327.9 & 0.036 & 2285 & 23.31 & 74.03 & 56.27 \\
\hline 172 & 2404.0 & 2327.8 & 0.035 & 2285 & 23.00 & 73.47 & 55.61 \\
\hline 175 & 2404.1 & 2327.9 & 0.036 & 2285 & 22.94 & 73.38 & 55.10 \\
\hline 176 & 2404.1 & 2327.9 & 0.036 & 2285 & 23.93 & 75.13 & 55.65 \\
\hline 177 & 2404.1 & 2327.9 & 0.036 & 2285 & 22.00 & 71.64 & 54.47 \\
\hline 178 & 2403.4 & 2327.2 & 0.035 & 2285 & 22.18 & 72.00 & 53.81 \\
\hline 179 & 2403.2 & 2327.0 & 0.035 & 2284 & 22.27 & 72.14 & 53.51 \\
\hline 182 & 2402.7 & 2326.5 & 0.035 & 2284 & 22.86 & 73.24 & 52.84 \\
\hline 183 & 2403.0 & 2326.8 & 0.035 & 2284 & 24.48 & 76.14 & 53.79 \\
\hline 184 & 2403.4 & 2327.2 & 0.035 & 2285 & 25.74 & 78.40 & 54.91 \\
\hline 186 & 2402.7 & 2326.5 & 0.035 & 2284 & 22.69 & 72.91 & 52.83 \\
\hline 189 & 2402.4 & 2326.2 & 0.035 & 2284 & 22.18 & 71.98 & 51.93 \\
\hline 190 & 2402.0 & 2325.8 & 0.035 & 2283 & 22.18 & 71.96 & 51.20 \\
\hline 191 & 2401.5 & 2325.3 & 0.034 & 2283 & 22.10 & 71.85 & 50.59 \\
\hline 193 & 2401.1 & 2324.9 & 0.034 & 2282 & 22.45 & 72.45 & 50.06 \\
\hline 196 & 2401.1 & 2324.9 & 0.034 & 2282 & 22.77 & 73.04 & 50.52 \\
\hline 197 & 2400.7 & 2324.5 & 0.034 & 2282 & 22.91 & 73.29 & 49.77 \\
\hline 198 & 2400.6 & 2324.4 & 0.034 & 2282 & 22.48 & 72.54 & 49.27 \\
\hline 200 & 2400.0 & 2323.8 & 0.034 & 2281 & 23.84 & 75.00 & 49.02 \\
\hline 203 & 2399.8 & 2323.6 & 0.034 & 2281 & 25.76 & 78.40 & 49.49 \\
\hline 204 & 2399.5 & 2323.3 & 0.033 & 2281 & 24.47 & 76.12 & 48.84 \\
\hline 205 & 2399.3 & 2323.1 & 0.033 & 2281 & 24.08 & 75.40 & 48.21 \\
\hline 206 & 2399.0 & 2322.8 & 0.033 & 2280 & 24.07 & 73.38 & 47.95 \\
\hline 207 & 2398.9 & 2322.7 & 0.033 & 2280 & 24.86 & 76.80 & 48.18 \\
\hline 210 & 2398.5 & 2322.3 & 0.033 & 2280 & 25.22 & 77.45 & 47.90 \\
\hline 211 & 2398.4 & 2322.2 & 0.033 & 2280 & 24.08 & 75.42 & 47.85 \\
\hline 212 & 2398.3 & 2322.1 & 0.033 & 2280 & 25.68 & 78.28 & 47.79 \\
\hline 213 & 2397.9 & 2321.7 & 0.033 & 2279 & 25.54 & 78.04 & 47.61 \\
\hline 214 & 2397.7 & 2321.5 & 0.033 & 2279 & 25.60 & 78.15 & 47.26 \\
\hline 217 & 2397.5 & 2321.3 & 0.033 & 2279 & 26.96 & 80.58 & 47.46 \\
\hline 218 & 2397.2 & 2321.0 & 0.032 & 2279 & 25.90 & 78.71 & 46.61 \\
\hline 219 & 2396.8 & 2320.6 & 0.032 & 2278 & 24.54 & 76.24 & 45.72 \\
\hline 220 & 2396.8 & 2320.6 & 0.032 & 2278 & 26.02 & 78.89 & 46.16 \\
\hline 221 & 2396.5 & 2320.3 & 0.032 & 2278 & 26.45 & 79.68 & 46.15 \\
\hline 224 & 2396.3 & 2320.1 & 0.032 & 2278 & 27.36 & 81.32 & 46.15 \\
\hline 225 & 2395.8 & 2319.6 & 0.032 & 2277 & 25.47 & 77.90 & 44.91 \\
\hline
\end{tabular}




\section{Data for sample T-H1 (continued)}

\begin{tabular}{|c|c|c|c|c|c|c|c|}
\hline \multirow{2}{*}{$\begin{array}{l}\text { Time } \\
\text { (Days) }\end{array}$} & \multirow{2}{*}{$\begin{array}{l}\text { Weight, } \\
W_{\text {Total }} \text { (g) }\end{array}$} & \multirow{2}{*}{$\begin{array}{l}\text { Weight, } \\
W(\mathrm{~g})\end{array}$} & \multirow{2}{*}{$\begin{array}{l}\text { Moisture } \\
\text { Content, } w\end{array}$} & \multirow{2}{*}{$\begin{array}{c}\text { Density, } \gamma_{\text {Moist }} \\
\left(\mathrm{kg} / \mathrm{m}^{3}\right)\end{array}$} & \multicolumn{2}{|c|}{ Temperature } & \multirow{2}{*}{$\begin{array}{l}\text { Rel. Humidity, } \\
\text { RH (\%) }\end{array}$} \\
\hline & & & & & ${ }^{\circ} \mathrm{C}$ & ${ }^{\circ} \mathrm{F}$ & \\
\hline 226 & 2395.7 & 2319.5 & 0.032 & 2277 & 24.23 & 75.67 & 44.33 \\
\hline 227 & 2395.6 & 2319.4 & 0.032 & 2277 & 23.00 & 73.42 & 43.83 \\
\hline 228 & 2395.4 & 2319.2 & 0.032 & 2277 & 22.77 & 73.04 & 43.54 \\
\hline 231 & 2395.8 & 2319.6 & 0.032 & 2277 & 23.33 & 74.01 & 44.06 \\
\hline 232 & 2395.5 & 2319.3 & 0.032 & 2277 & 22.78 & 73.06 & 43.21 \\
\hline 233 & 2395.4 & 2319.2 & 0.032 & 2277 & 22.98 & 73.46 & 43.16 \\
\hline 234 & 2395.4 & 2319.2 & 0.032 & 2277 & 22.80 & 73.11 & 43.01 \\
\hline 235 & 2395.1 & 2318.9 & 0.032 & 2277 & 22.66 & 72.82 & 42.66 \\
\hline 238 & 2394.5 & 2318.3 & 0.031 & 2276 & 23.28 & 73.98 & 42.27 \\
\hline 239 & 2394.4 & 2318.2 & 0.031 & 2276 & 23.00 & 73.49 & 42.04 \\
\hline 240 & 2394.4 & 2318.2 & 0.031 & 2276 & 23.25 & 73.90 & 42.06 \\
\hline 241 & 2394.0 & 2317.8 & 0.031 & 2275 & 23.13 & 76.68 & 41.68 \\
\hline 242 & 2393.7 & 2317.5 & 0.031 & 2275 & 22.58 & 72.68 & 41.39 \\
\hline 245 & 2394.0 & 2317.8 & 0.031 & 2275 & 22.32 & 72.25 & 40.96 \\
\hline 246 & 2393.7 & 2317.5 & 0.031 & 2275 & 22.84 & 73.17 & 40.78 \\
\hline 247 & 2393.7 & 2317.5 & 0.031 & 2275 & 22.56 & 72.64 & 40.62 \\
\hline 248 & 2393.7 & 2317.5 & 0.031 & 2275 & 22.72 & 72.97 & 40.47 \\
\hline 249 & 2393.6 & 2317.4 & 0.031 & 2275 & 21.93 & 71.53 & 39.98 \\
\hline 252 & 2393.7 & 2317.5 & 0.031 & 2275 & 22.83 & 73.13 & 39.74 \\
\hline 253 & 2393.7 & 2317.5 & 0.031 & 2275 & 22.48 & 72.50 & 39.30 \\
\hline 254 & 2394.2 & 2318.0 & 0.031 & 2276 & 22.86 & 73.20 & 39.88 \\
\hline 256 & 2393.6 & 2317.4 & 0.031 & 2275 & 23.08 & 73.58 & 38.68 \\
\hline 259 & 2393.7 & 2317.5 & 0.031 & 2275 & 23.88 & 73.58 & 38.49 \\
\hline 260 & 2394.0 & 2317.8 & 0.031 & 2275 & 23.18 & 73.72 & 38.22 \\
\hline 261 & 2394.4 & 2318.2 & 0.031 & 2276 & 24.38 & 75.94 & 39.02 \\
\hline 262 & 2394.1 & 2317.9 & 0.031 & 2276 & 23.59 & 74.52 & 38.26 \\
\hline 263 & 2393.8 & 2317.6 & 0.031 & 2275 & 25.25 & 77.54 & 38.29 \\
\hline 266 & 2394.2 & 2318.0 & 0.031 & 2276 & 25.82 & 78.51 & 38.96 \\
\hline 267 & 2394.3 & 2318.1 & 0.031 & 2276 & 25.93 & 78.71 & 39.18 \\
\hline 268 & 2393.8 & 2317.6 & 0.031 & 2275 & 23.25 & 73.90 & 37.58 \\
\hline 269 & 2393.6 & 2317.4 & 0.031 & 2275 & 23.42 & 74.23 & 37.49 \\
\hline 270 & 2393.9 & 2317.7 & 0.031 & 2275 & 23.92 & 75.11 & 37.81 \\
\hline 273 & 2393.5 & 2317.3 & 0.031 & 2275 & 22.59 & 72.68 & 36.59 \\
\hline 274 & 2393.5 & 2317.3 & 0.031 & 2275 & 23.93 & 75.14 & 36.51 \\
\hline 275 & 2393.7 & 2317.5 & 0.031 & 2275 & 26.58 & 79.90 & 37.94 \\
\hline 276 & 2394.1 & 2317.9 & 0.031 & 2276 & 25.94 & 78.71 & 38.29 \\
\hline 277 & 2393.9 & 2317.7 & 0.031 & 2275 & 22.87 & 73.20 & 36.75 \\
\hline 280 & 2393.5 & 2317.3 & 0.031 & 2275 & 24.15 & 75.52 & 36.33 \\
\hline 282 & 2393.3 & 2317.1 & 0.031 & 2275 & 24.40 & 76.06 & 36.08 \\
\hline
\end{tabular}




\section{Data for sample T-H1 (continued)}

\begin{tabular}{|c|c|c|c|c|c|c|c|}
\hline \multirow{2}{*}{$\begin{array}{c}\text { Time } \\
\text { (Days) }\end{array}$} & \multirow{2}{*}{$\begin{array}{l}\text { Weight, } \\
W_{\text {Total }}(\mathrm{g})\end{array}$} & \multirow{2}{*}{$\begin{array}{l}\text { Weight, } \\
W(\mathrm{~g})\end{array}$} & \multirow{2}{*}{$\begin{array}{l}\text { Moisture } \\
\text { Content, } w\end{array}$} & \multirow{2}{*}{$\begin{array}{c}\text { Density, YMoist } \\
\left(\mathrm{kg} / \mathrm{m}^{3}\right)\end{array}$} & \multicolumn{2}{|c|}{ Temperature } & \multirow{2}{*}{$\begin{array}{l}\text { Rel. Humidity, } \\
\text { RH (\%) }\end{array}$} \\
\hline & & & & & ${ }^{\circ} \mathrm{C}$ & ${ }^{\circ} \mathrm{F}$ & \\
\hline 283 & 2393.3 & 2317.1 & 0.031 & 2275 & 22.42 & 72.41 & 35.20 \\
\hline 284 & 2394.3 & 2318.1 & 0.031 & 2276 & 25.79 & 78.48 & 37.59 \\
\hline 287 & 2394.2 & 2318.0 & 0.031 & 2276 & 24.94 & 77.02 & 35.52 \\
\hline 288 & 2394.2 & 2318.0 & 0.031 & 2276 & 25.54 & 78.06 & 37.50 \\
\hline 289 & 2394.8 & 2318.6 & 0.031 & 2276 & 23.40 & 74.21 & 37.58 \\
\hline 290 & 2394.9 & 2318.7 & 0.031 & 2276 & 23.50 & 74.37 & 38.08 \\
\hline 291 & 2395.2 & 2319.0 & 0.032 & 2277 & 22.89 & 73.27 & 38.32 \\
\hline 294 & 2394.8 & 2318.6 & 0.031 & 2276 & 22.93 & 73.34 & 38.60 \\
\hline 295 & 2395.0 & 2318.8 & 0.031 & 2276 & 22.60 & 72.14 & 39.07 \\
\hline 296 & 2394.6 & 2318.4 & 0.031 & 2276 & 22.96 & 73.38 & 39.01 \\
\hline 297 & 2394.5 & 2318.3 & 0.031 & 2276 & 22.97 & 73.40 & 38.94 \\
\hline 298 & 2395.1 & 2318.9 & 0.032 & 2277 & 22.42 & 72.41 & 39.83 \\
\hline 301 & 2395.5 & 2319.3 & 0.032 & 2277 & 23.28 & 73.98 & 41.00 \\
\hline 302 & 2395.2 & 2319.0 & 0.032 & 2277 & 21.73 & 71.15 & 40.49 \\
\hline 303 & 2395.0 & 2318.8 & 0.031 & 2276 & 22.14 & 70.86 & 40.46 \\
\hline 304 & 2394.8 & 2318.6 & 0.031 & 2276 & 22.68 & 72.86 & 40.53 \\
\hline 305 & 2394.4 & 2318.2 & 0.031 & 2276 & 23.84 & 74.98 & 40.42 \\
\hline 308 & 2394.5 & 2318.3 & 0.031 & 2276 & 22.98 & 73.44 & 40.09 \\
\hline 309 & 2394.5 & 2318.3 & 0.031 & 2276 & 22.72 & 72.95 & 39.86 \\
\hline 310 & 2394.5 & 2318.3 & 0.031 & 2276 & 22.96 & 73.40 & 39.82 \\
\hline 311 & 2394.6 & 2318.4 & 0.031 & 2276 & 22.82 & 73.11 & 39.70 \\
\hline 312 & 2394.6 & 2318.4 & 0.031 & 2276 & 22.78 & 73.04 & 39.72 \\
\hline 315 & 2395.0 & 2318.8 & 0.031 & 2276 & 22.90 & 73.29 & 40.15 \\
\hline 316 & 2395.5 & 2319.3 & 0.032 & 2277 & 23.58 & 74.50 & 41.10 \\
\hline 317 & 2395.6 & 2319.4 & 0.032 & 2277 & 23.68 & 74.68 & 41.64 \\
\hline 318 & 2395.8 & 2319.6 & 0.032 & 2277 & 23.40 & 74.05 & 41.87 \\
\hline 319 & 2395.9 & 2319.7 & 0.032 & 2277 & 22.82 & 73.11 & 42.15 \\
\hline 322 & 2396.2 & 2320.0 & 0.032 & 2278 & 23.10 & 73.65 & 43.84 \\
\hline 323 & 2396.2 & 2320.0 & 0.032 & 2278 & 23.42 & 73.21 & 44.60 \\
\hline 324 & 2396.0 & 2319.8 & 0.032 & 2277 & 23.88 & 75.04 & 44.46 \\
\hline 325 & 2395.9 & 2319.7 & 0.032 & 2277 & 22.82 & 73.15 & 44.33 \\
\hline 326 & 2396.2 & 2320.0 & 0.032 & 2278 & 23.17 & 73.74 & 45.10 \\
\hline 329 & 2396.8 & 2320.6 & 0.032 & 2278 & 24.18 & 75.56 & 46.99 \\
\hline 330 & 2396.8 & 2320.6 & 0.032 & 2278 & 23.22 & 73.87 & 46.90 \\
\hline 331 & 2396.8 & 2320.6 & 0.032 & 2278 & 22.68 & 72.84 & 46.87 \\
\hline 332 & 2396.6 & 2320.4 & 0.032 & 2278 & 22.91 & 73.29 & 47.09 \\
\hline 333 & 2396.5 & 2320.3 & 0.032 & 2278 & 24.00 & 75.27 & 47.58 \\
\hline 339 & 2397.2 & 2321.0 & 0.032 & 2279 & 22.86 & 73.22 & 48.84 \\
\hline 340 & 2397.4 & 2321.2 & 0.033 & 2279 & 22.59 & 72.72 & 48.70 \\
\hline
\end{tabular}




\section{Data for sample T-H1 (continued)}

\begin{tabular}{|c|c|c|c|c|c|c|c|}
\hline \multirow{2}{*}{$\begin{array}{c}\text { Time } \\
\text { (Days) }\end{array}$} & \multirow{2}{*}{$\begin{array}{l}\text { Weight, } \\
W_{\text {Total }} \text { (g) }\end{array}$} & \multirow{2}{*}{$\begin{array}{c}\text { Weight, } \\
\text { W (g) }\end{array}$} & \multirow{2}{*}{$\begin{array}{l}\text { Moisture } \\
\text { Content, } w\end{array}$} & \multirow{2}{*}{$\begin{array}{c}\text { Density, YMoist } \\
\left(\mathrm{kg} / \mathrm{m}^{3}\right)\end{array}$} & \multicolumn{2}{|c|}{ Temperature } & \multirow{2}{*}{$\begin{array}{c}\text { Rel. Humidity, } \\
\text { RH (\%) }\end{array}$} \\
\hline & & & & & ${ }^{\circ} \mathrm{C}$ & ${ }^{\circ} \mathrm{F}$ & \\
\hline 343 & 2397.5 & 2321.3 & 0.033 & 2279 & 22.06 & 71.76 & 49.37 \\
\hline 345 & 2398.3 & 2322.1 & 0.033 & 2280 & 20.65 & 69.24 & 49.83 \\
\hline 347 & 2398.5 & 2322.3 & 0.033 & 2280 & 22.45 & 72.46 & 51.11 \\
\hline 350 & 2398.0 & 2321.8 & 0.033 & 2279 & 26.00 & 78.87 & 52.83 \\
\hline 352 & 2398.2 & 2322.0 & 0.033 & 2280 & 23.60 & 74.53 & 52.66 \\
\hline 354 & 2398.2 & 2322.0 & 0.033 & 2280 & 23.10 & 74.37 & 52.37 \\
\hline 357 & 2398.3 & 2322.1 & 0.033 & 2280 & 23.38 & 74.16 & 53.32 \\
\hline 359 & 2398.2 & 2322.0 & 0.033 & 2280 & 23.31 & 74.01 & 53.41 \\
\hline 360 & 2398.4 & 2322.2 & 0.033 & 2280 & 23.05 & 75.56 & 53.53 \\
\hline 361 & 2398.4 & 2322.2 & 0.033 & 2280 & 23.18 & 73.8 & 53.64 \\
\hline 364 & 2398.4 & 2322.2 & 0.033 & 2280 & 23.02 & 73.49 & 53.93 \\
\hline 365 & 2398.5 & 2322.3 & 0.033 & 2280 & 23.69 & 74.73 & 54.15 \\
\hline 368 & 2398.4 & 2322.2 & 0.033 & 2280 & 23.12 & 73.67 & 54.10 \\
\hline
\end{tabular}


Temperature and moisture content plots for sample T-H1
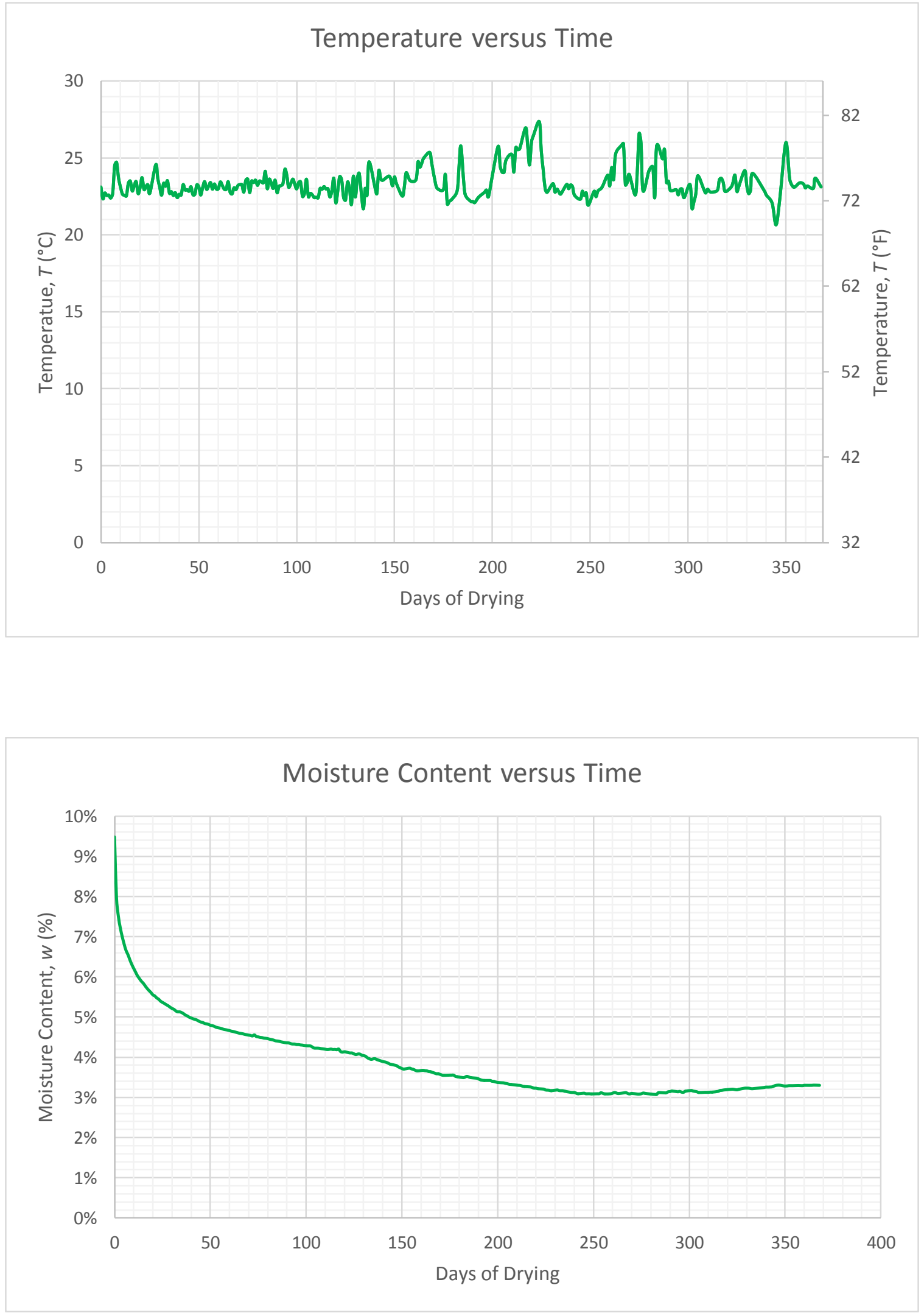


\section{Relative humidity plots for sample T-H1}
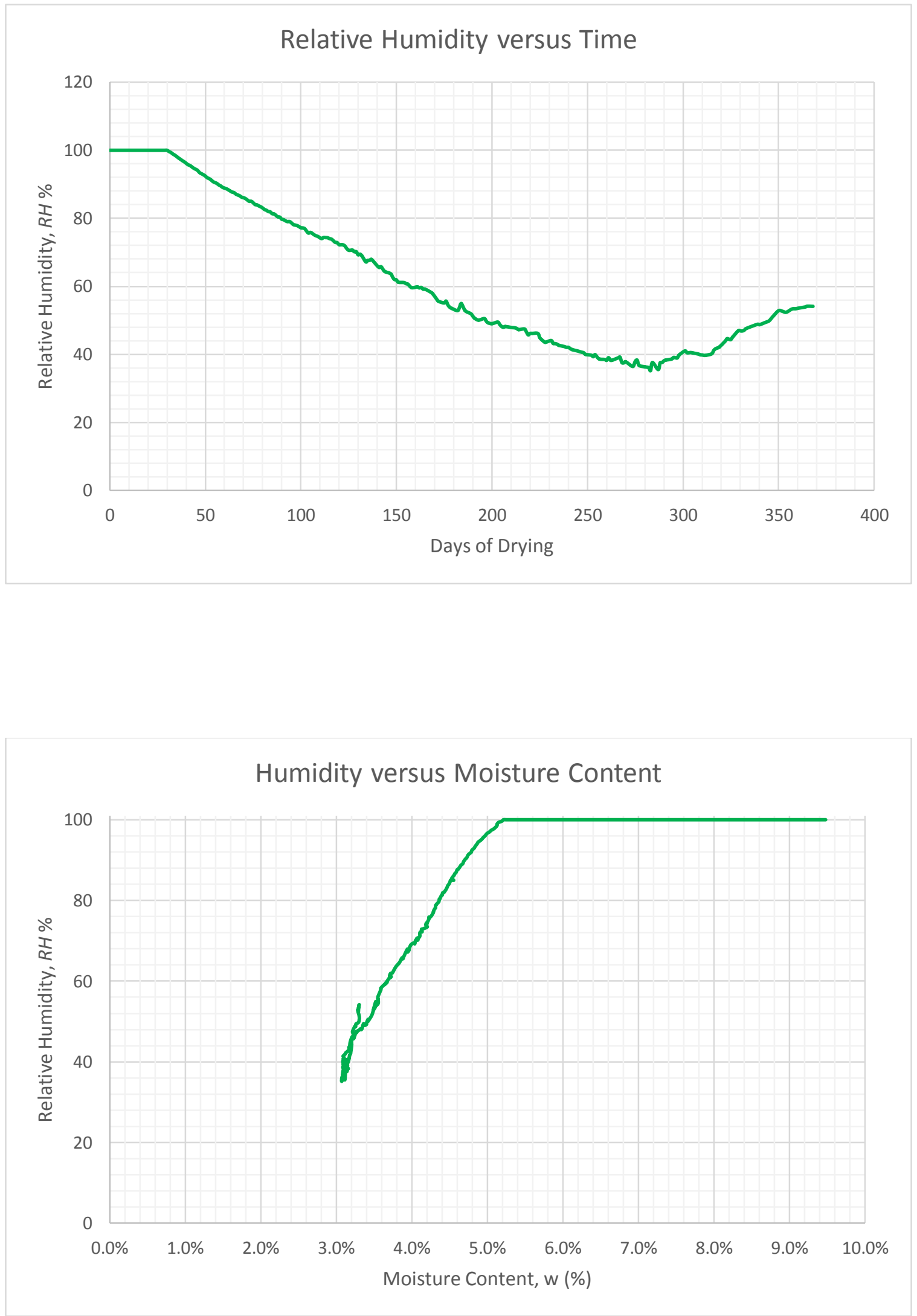


\section{Data plots for all samples (R1, R2, and T-H1)}
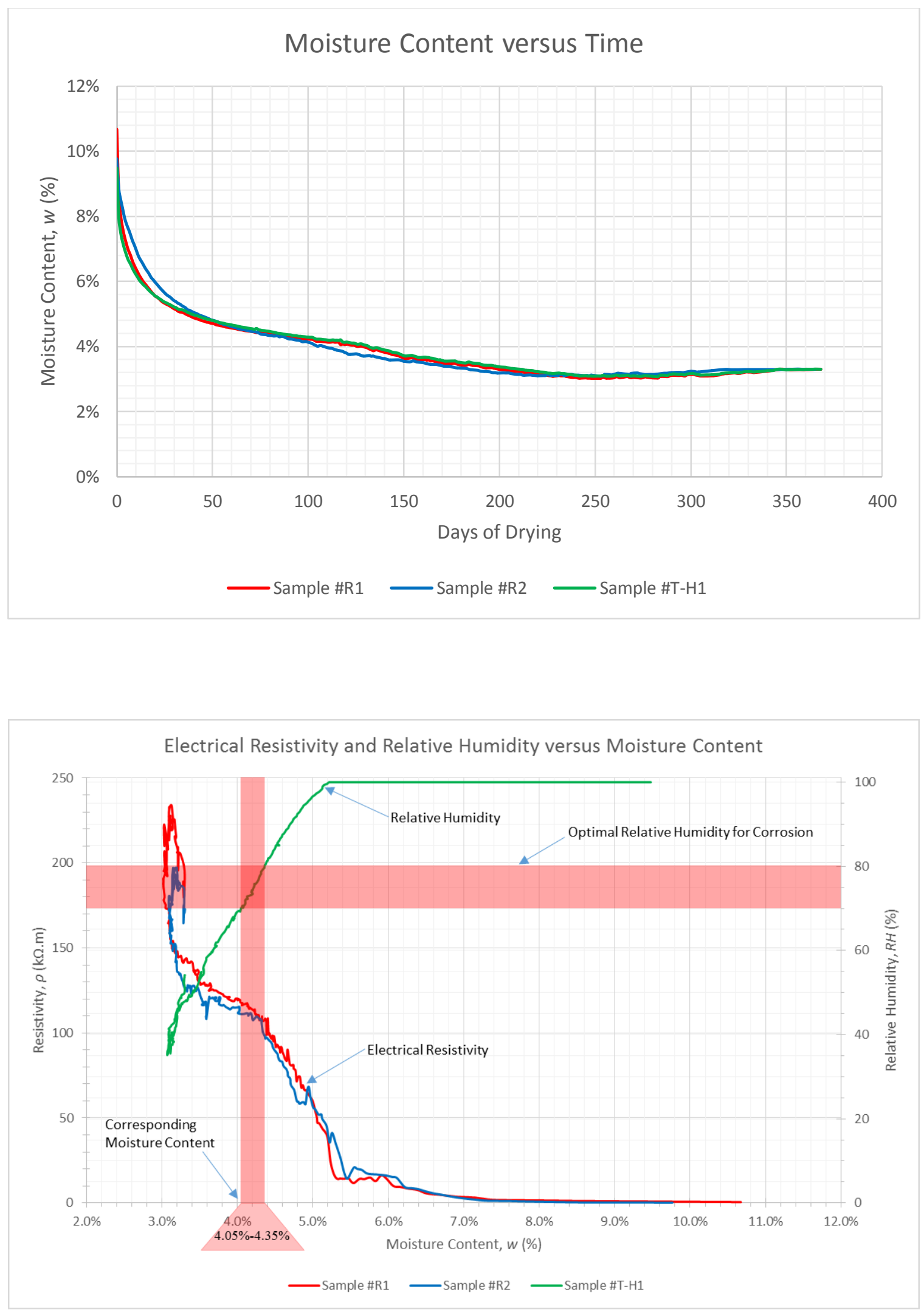